\title{
Bioindicadores vegetais de poluição atmosférica: uma contribuição para a saúde da comunidade
}

\author{
Regina Maria Alves Carneiro
}

Dissertação apresentada ao Programa de PósGraduação Enfermagem em Saúde Pública, do Departamento de Enfermagem Materno-Infantil e Saúde Pública da Escola de Enfermagem de Ribeirão Preto da Universidade de São Paulo, para obtenção do título de Mestre em Enfermagem em Saúde Pública. Inserida na linha de pesquisa: Saúde Ambiental. 
UNIVERSIDADE DE SÃO PAULO

ESCOLA DE ENFERMAGEM DE RIBEIRÃO PRETO

\title{
Bioindicadores vegetais de poluição atmosférica: uma contribuição para a saúde da comunidade
}

\author{
Regina Maria Alves Carneiro
}

\begin{abstract}
Dissertação apresentada ao Programa de PósGraduação Enfermagem em Saúde Pública, do Departamento de Enfermagem Materno-Infantil e Saúde Pública da Escola de Enfermagem de Ribeirão Preto da Universidade de São Paulo, para obtenção do título de Mestre em Enfermagem em Saúde Pública. Inserida na linha de pesquisa: Saúde Ambiental.
\end{abstract}

Orientadora: Prof ${ }^{a}$. Dr ${ }^{\mathrm{a}}$. Angela Maria Magosso Takayanagui

\section{RIBEIRÃO PRETO}


Autorizo a reprodução total ou parcial deste trabalho, para qualquer meio convencional ou eletrônico, para fins de estudo e pesquisa, desde que citada a fonte.

\section{FICHA CATALOGRÁFICA}

Regina Maria Alves Carneiro

Bioindicadores vegetais de poluição atmosférica: uma contribuição para a saúde da comunidade.

146 p. : il. ; 30cm

Dissertação apresentada à Escola de Enfermagem de Ribeirão Preto/USP - Área de concentração: Enfermagem em Saúde Pública.

Orientadora: Takayanagui, Angela Maria Magosso.

1. bioindicador vegetal. 2. poluição atmosférica. 3. avaliação de risco ambiental. 4. biomonitoramento. 


\section{FOLHA DE APROVAÇÃO}

Regina Maria Alves Carneiro

Bioindicadores vegetais de poluição atmosférica: uma contribuição para a saúde da comunidade.

Dissertação apresentada à Escola de Enfermagem de Ribeirão Preto da Universidade de São Paulo para obtenção do título de Mestre em Enfermagem em Saúde Pública

Aprovado em:

\section{Banca Examinadora}

Prof. Dr.

Julgamento: Assinatura:

Prof. Dr.

Julgamento: Assinatura:

Prof. Dr.

Julgamento: Assinatura: 


\section{AGRADECIMENTOS}

Agradeço a todos aqueles que comigo compartilharam, direta ou indiretamente, na realização deste trabalho que, para mim, representa a concretização de mais um dos meus objetivos.

As pessoas que colaboraram para que ele chegasse a um "final feliz" fazem parte integrante do todo aqui contido e, principalmente, da minha história.

Em especial, quero agradecer àqueles que dispuseram seus conhecimentos e aptidões pessoais para a realização do que acabou por se transformar na presente dissertação.

À Prefeitura Municipal de Ribeirão Preto, onde trabalho, por permitir que parte do meu tempo fosse dedicada ao curso de mestrado.

Ao Laboratório de Poluição Atmosférica Experimental - LPAE, da Faculdade de Medicina da Universidade de São Paulo, que disponibilizou trabalhos científicos desenvolvidos por sua equipe.

Aos bibliotecários e bibliotecárias da Biblioteca Central do Campus de Ribeirão Preto, da Sala de Leitura da Escola de Enfermagem de Ribeirão Preto e da Biblioteca da Faculdade de Saúde Pública da Universidade de São Paulo, que possibilitaram um acesso tranqüilo e seguro aos acervos.

À Andréia Heloisa da Costa, pelo excelente trabalho de digitação e organização dos textos, na formatação necessária.

À Bióloga Débora-Jã de Araújo Lobo, do LPAE-USP, que me apresentou os trabalhos ali desenvolvidos com plantas bioindicadoras e disponibilizou parte de seu arquivo pessoal, enriquecendo esta pesquisa.

À Dra. Leny Borghesan A. Alberguini, do Laboratório de Resíduos Químicos, HUUSP/São Carlos, pelos esclarecimentos quanto à natureza química de certos poluentes aqui considerados. 
À Dra. Olga Kotchetkoff Henriques e à Profa. Dra. Silvana Aparecida de Godoy, do Departamento de Biologia, FFCLRP-USP, pelos valiosos esclarecimento nos assuntos de Botânica Sistemática.

À Profa. Dra. Maria Lúcia Arruda de Moura Campos, do Departamento de Química, FFCLRP-USP, por dedicar especial atenção para que eu melhor assimilasse as questões de química ambiental.

À Profa. Dra. Suzana Inés Segura Muñoz, do Laboratório de Saúde Ambiental, EERP-USP, por toda colaboração dedicada durante o processo de desenvolvimento deste trabalho e pela valiosa ajuda na versão do resumo em sua língua natal, o Espanhol.

Aos docentes das disciplinas de Mestrado da Escola de Enfermagem de Ribeirão Preto da Universidade de São Paulo, pela dedicação aos iniciantes na pesquisa científica.

Aos docentes da disciplina "Seminário sobre Pesquisa em Saúde I e II”, Profa. Daisy, Profa. Emília, Profa. Amábile e Prof. Geraldo, que nos ajudaram a trilhar o emaranhado caminho da construção dos projetos de pesquisa, com paciência e bom humor.

Aos componentes da banca de defesa da dissertação: Profa. Dra. Daisy Leslie Seagall Gomes, Profa. Dra. Elenice Mouro Varanda, Prof. Dr. Geraldo Garcia Duarte, que dedicaram muito dos seus preciosos tempos na leitura, correção e orientação geral do trabalho.

À Profa. Dra. Angela Maria Magosso Takayanagui, minha orientadora incansável e perseverante, que não mediu esforços desde o momento de minha proposição inicial, para ver a concretização deste trabalho. E, principalmente, por acreditar que ele fosse possível!

Aos meus Amigos, pela Amizade.

Aos meus irmãos Thomaz, Lélia e Patrícia, e cunhados Luciana e Wolf, por estarem sempre presentes, nas horas doces e naquelas mais difíceis.

Aos meus sobrinhos Thiago, Thais, Júlia, Leonardo, Pedro, Hermann e Klaus, pelas crianças que foram e são, permitindo-me viver momentos de muita alegria junto a vocês.

Aos meus queridos pais, Lelian (in memorian) e Cidinha, que me deram a oportunidade de nascer e por todo o Amor eternamente dedicado.

A Deus, pelo dom da Vida. 


\section{SUMÁRIO}

Apresentação

Lista de Ilustrações

Lista de Quadros

Lista de Abreviaturas e Siglas

Lista de Símbolos de Elementos e Substâncias Químicas

Resumo

Abstract

Resumen

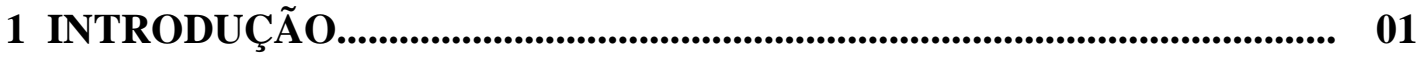

1.1 Saúde, ambiente e desenvolvimento.................................................... 01

1.2 Poluição atmosférica................................................................................ 05

1.2.1 Poluentes atmosféricos.................................................................. 05

1.2.2 Poluição atmosférica e saúde humana.............................................. 11

1.2.3 Legislação sobre qualidade do ar....................................................... 12

1.3 A vegetação como bioindicador da poluição atmosférica........................... 19

1.4 Avaliação, percepção e comunicação de risco ambiental........................... 28

1.4.1 O Distrito Industrial de Ribeirão Preto (DIRP) como fonte potencial de poluição ambiental............................................................................ 31

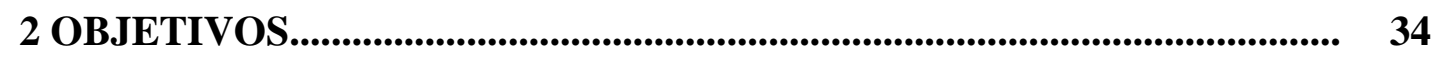

2.1 Objetivo geral....................................................................................... 34

2.2 Objetivos específicos........................................................................... $\quad 34$

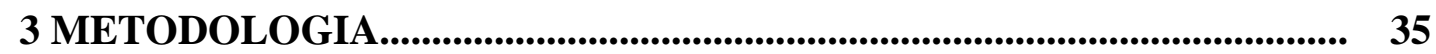

3.1 Revisão sistemática da literatura............................................................... 36

3.2 Percurso metodológico............................................................................ 37

3.2.1 - Elaboração dos instrumentos de coleta de dados.......................... 37

3.2.2 Fonte de dados............................................................................ 38

3.2.3 Coleta de dados........................................................................... 42

3.2.4 Compilação e análise dos dados.................................................... 43 
4.1 Quanto a Revisão Sistemática da Literatura............................................. 45

4.1.1 Levantamento nos Bancos e Bases de Dados................................... 46

4.1.2 Aplicação dos testes de relevância TR1 e TR2.................................. 51

4.2 Quanto ao uso de bioindicadores vegetais de poluição atmosférica........... 69

4.2.1 Gêneros e espécies vegetais encontrados com maior freqüência nesta investigação, utilizados no Brasil e no mundo................................. 77

4.2.1.1 Angiospermas............................................................... 77

4.2.1.2 Coniferofitas................................................................... 86

4.2.1.3 Musgos....................................................................... 90

4.2.1.4 Líquens...................................................................... 95

4.2.2 Gêneros e espécies vegetais encontrados com menor freqüência nesta investigação, com ocorrência natural ou cultivada no

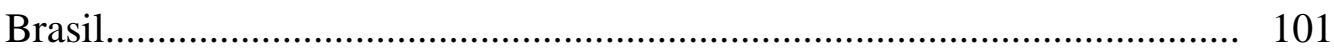

4.2.2.1 Angiospermas............................................................... 101

4.2.2.2 Coniferofitas................................................................ 111

4.2.2.3 Líquens..................................................................... 112

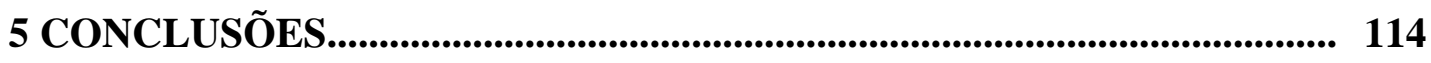

5.1 Sobre a Revisão Sistemática da Literatura............................................... 114

6.2 Sobre os bioindicadores vegetais em processos de poluição atmosférica.... 115

6 CONSIDERAÇÕES FINAIS.......................................................................... 117

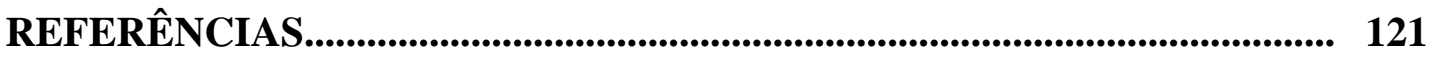

APÊNDICES

APÊNDICE A: Teste de Relevância 1 (TR1)................................................... 145

APÊNDICE B: Teste de Relevância 2 (TR2).................................................. 146 


\section{APRESENTAÇÃO}

Enquanto profissional da área de meio ambiente, ligada à administração pública do município de Ribeirão Preto, participo, cotidianamente, de questões de ordem tecnoadministrativas, no âmbito das políticas municipais de meio ambiente, voltadas para a melhoria da qualidade de vida da comunidade.

Dentre as diversas atividades desenvolvidas junto a esse setor, destaco o processo de licenciamento do Distrito Industrial de Ribeirão Preto - SP (DIRP), que gerou, inicialmente, nosso interesse em desenvolver uma investigação acadêmica dentro de um curso de pós-graduação, visando a um maior conhecimento sobre o uso de novos instrumentos de controle da poluição ambiental, tendo em vista a minimização do impacto de um complexo industrial nos espaços urbanos.

A organização espacial das cidades, se não adequadamente planejada e monitorada, levando em consideração os efeitos negativos de emissões poluentes de diferentes naturezas, pode favorecer a ocorrência de impactos diretos à saúde da população e aos recursos naturais, muitas vezes extrapolando os limites administrativos de um dado município.

Destacamos, assim, como tema de nossa pesquisa, uma importante faceta da questão do gerenciamento ambiental, referente ao uso de bioindicadores vegetais de poluição atmosférica, como método complementar ao sistema existente de controle da 
poluição ambiental, de emissões atmosféricas poluentes decorrentes da atividade humana, principalmente nos centros urbanos.

Assim, esta investigação foi desenvolvida visando contribuir para o conhecimento acadêmico na área de poluição atmosférica ligada, principalmente, a processos industriais, com vistas à sua utilização nas tomadas de decisão políticoadministrativa dos municípios.

Esta pesquisa foi organizada em 6 capítulos. No primeiro capítulo são apresentados aspectos do panorama ambiental da atualidade, destacando a poluição atmosférica como base para a construção do nosso objeto de estudo. No segundo capítulo são apresentados os objetivos pretendidos, seguido pela base metodológica em que foi desenvolvida esta pesquisa, em seu capítulo terceiro. No quarto capítulo são apresentados e discutidos os resultados alcançados. O quinto capítulo reúne as conclusões e, o sexto capítulo, as considerações finais da investigação.

Desejamos, com esta investigação, estar contribuindo, tanto para a área acadêmica, trazendo novos conhecimentos acerca dos diferentes bioindicadores vegetais de poluição atmosférica, que têm sido utilizados em diferentes países, e divulgados no meio científico, quanto para os setores públicos e privados que têm o compromisso com o gerenciamento da qualidade do ar de centros urbanos, tendo como perspectiva a efetiva melhoria na qualidade de vida dos cidadãos atuais e das futuras gerações. 


\section{LISTA DE ILUSTRAÇÕES}

Figura 1 - Localização do Distrito Industrial de Ribeirão Preto (DIRP).......... 33

Figura 2 - Esquema dos passos percorridos para a Revisão Sistemática da

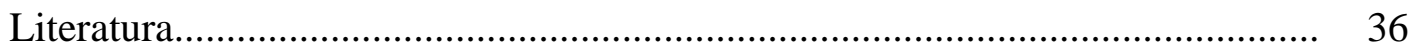




\section{LISTA DE QUADROS}

Quadro 1 - Limites máximos de concentração de alguns contaminantes presentes na atmosfera recomendados pela OMS - 1995

Quadro 2 - Padrões Primário e Secundário de qualidade do ar e métodos de medição, segundo Resolução CONAMA n. ${ }^{\circ}$ 03/90

Quadro 3 - Critérios para episódios agudos de poluição do ar.

Quadro 4 - Qualidade do ar em relação ao IQA

Quadro 5 - Total de artigos científicos encontrados e total de artigos selecionados, excluídos e com dúvida, após aplicação do TR1

Quadro 6 - Resultados da aplicação do TR2 por base ou banco de dados consultados, segundo o número de artigos obtidos na íntegra

Quadro 7 - Síntese dos dados obtidos por Revisão Sistemática da Literatura aplicada para uso de bioindicadores vegetais de poluição atmosférica

Quadro 8 - Relação das espécies vegetais referidas como bioindicadores de poluição atmosférica pertencentes à Divisão Angiospermae.

Quadro 9 - Relação de espécies vegetais referidas como bioindicadores de poluição atmosférica pertencentes à Divisão Coniferophyta

Quadro 10 - Musgos Bioindicadores de Poluição Atmosférica....

Quadro 11 - Líquens Bioindicadores de Poluição Atmosférica..... 


\section{RESUMO}

CARNEIRO, R.M.A. Bioindicadores vegetais de poluição atmosférica: uma contribuição para a saúde da comunidade. 2004. 146 p. Dissertação de Mestrado - Escola de Enfermagem de Ribeirão Preto, Universidade de São Paulo, Ribeirão Preto.

A qualidade do ar nas áreas urbanas e industriais tende a apresentar concentrações indesejáveis de contaminantes, sem que haja um sistema abrangente de monitoramento, dada a sofisticação dos métodos físico-químicos convencionais, que requerem custos elevados de implantação, operação e manutenção, custos estes, que podem ser minimizados pela adoção de metodologia complementar de biomonitoramento. O biomonitoramento é um método experimental que permite avaliar a resposta de organismos vivos à poluição, oferecendo vantagens como: custos reduzidos, eficiência para o monitoramento de áreas amplas e por longos períodos de tempo e, também, avaliação de elementos químicos em baixas concentrações ambientais. As medidas e registros efetuados por redes convencionais de monitoramento da qualidade do ar permitem verificar se normas e limites estabelecidos ou recomendados pela legislação, agências ambientais e órgãos de promoção da saúde humana estão sendo respeitados. Entretanto, tais medições não permitem conclusões imediatas sobre as conseqüências de poluentes nos seres vivos. Assim, o biomonitoramento deve ser considerado como um método complementar na análise de poluentes, podendo constituir-se em um terceiro sistema de informações, além dos inventários de emissões e de concentrações ambientais. O presente trabalho teve por objetivo identificar, por meio de revisão sistemática de literatura desenvolvida por dois revisores independentes, espécies vegetais (vasculares, musgos e líquens) utilizadas como bioindicadores, referente ao período de janeiro de 1997 a junho de 2003, em estudos experimentais e observacionais, associando-as a poluentes atmosféricos. De um total de 4547 trabalhos científicos sobre bioindicadores, foram préselecionados 279 estudos referentes ao uso de vegetais bioindicadores de poluição atmosférica, publicados nos idiomas inglês, espanhol e português. Estes trabalhos foram analisados pela aplicação de dois testes de relevância, sendo selecionadas 240 referências e obtidos 154 estudos na íntegra. Deste total, foram incluídos, após aplicação dos dois testes de relevância, 126 trabalhos científicos, sobre o tema considerado, realizados em 34 diferentes países. Constatou-se que o uso da metodologia de revisão sistemática permitiu levantar o conhecimento das experiências acadêmicas nesta área de estudo, ampliando o conhecimento sobre esse tema. Os resultados ainda revelaram a utilização de 112 espécies vegetais, sendo 64 espécies pertencentes à divisão Angiospermae; 11 espécies da divisão Coniferophyta; 22 espécies de líquens e 15 espécies de musgos, relacionadas ao monitoramento de um ou mais dos seguintes poluentes atmosféricos: metais pesados, ozônio, material particulado, dióxido de enxofre, óxidos de nitrogênio, monóxido de carbono, fluoretos, compostos orgânicos voláteis e hidrocarbonetos. Constatou-se, assim, a existência de uma quantidade significativa de estudos dessa natureza, principalmente nos países europeus, onde está implantado o projeto EUROBIONET de biomonitoramento de poluição atmosférica, baseado na padronização de ensaios e biomonitores, desde o ano 2000. Tendo em vista que determinados bioindicadores já estão consagrados ou mesmo validados para o monitoramento de poluentes atmosféricos específicos, considera-se ser possível a instalação de uma rede de biomonitoramento ambiental no Estado de São Paulo, a partir de um trabalho conjunto e coordenado entre universidades, municípios e agência de proteção ambiental, associada à rede existente de monitoramento convencional da qualidade do ar. Tal iniciativa permitirá que mais um passo seja dado na universalização dos cuidados com os ambientes natural e social, promovendo e garantindo melhorias no padrão de qualidade de vida das sociedades atuais e futuras.

Palavras-chave: bioindicador vegetal, poluição atmosférica, avaliação de risco ambiental, biomonitoramento. 


\begin{abstract}
CARNEIRO, R.M.A. Vegetal bioindicators of atmospheric pollution: a contribution to community health. 2004. 146 p. Dissertation (Masters) - University of São Paulo at Ribeirão Preto College of Nursing.
\end{abstract}

Air quality in urban and industrial areas tends to present undesirable concentrations of contaminants, without the availability of a broad monitoring system, given the sophistication of conventional physical-chemical methods, which require high expenditure for implantation, operation and maintenance. These costs can be reduced by the adoption of the complementary biomonitoring methodology. Biomonitoring is an experimental methodology that allows us to evaluate the response of living organisms to pollution, including advantages such as: reduced costs; efficiency to monitor large areas over long periods of time; evaluation of chemical elements in low environmental concentrations. Measurements and registers by conventional air quality monitoring networks allow us to verify whether the standards and limits set by legislation, environmental agencies and human health promotion bodies are being respected. However, these measurements do not allow for immediate conclusions about the consequences of polluting agents for human beings. Thus, biomonitoring must be considered a complementary method for analyzing pollutant agents and can constitute a third information system, besides emission and environmental concentration inventories. This study aimed to identify, by means of a systematic literature review carried out by two peer independent reviewers, vegetal species (vascular, moss and lichen) that are used as bioindicators, in the period from January 1997 to June 2003, in experimental and observational studies, linking them up with atmospheric pollutant agents. Out of a total of 4,547 scientific studies on bioindicators, 279 studies about the use of vegetal atmospheric pollution indicators were preselected, published in English, Spanish and Portuguese. These studies were analyzed by means of two relevancy tests, resulting in the selection of 240 references and 154 full studies. Out of this total, after applying the two relevancy tests, we included 126 scientific studies from 34 different countries. The systematic review methodology allowed us to survey the knowledge resulting from academic experiments in this field of study, thus broadening the knowledge related to that theme. Results disclosed the use of 111 vegetal species, 63 of which belonged to the Angiospermae group; 11 to the Coniferophyta group; 15 moss species and 22 lichen species, related to the monitoring of one or more of the following atmospheric polluting agents: heavy metals, ozone, particles, sulfur dioxide, nitrogen oxides, carbon monoxide, fluorides, volatile organic compounds. Thus, we observed that there is a significant amount of this kind of studies, mainly in European countries, where the EUROBIONET project for biomonitoring atmospheric pollution has been implanted since 2000, based on test and biomonitor standardization. In view of the fact that certain bioindicators are already acclaimed or even validated for monitoring specific atmospheric polluting agents, we believe it is possible to install an environmental biomonitoring network in São Paulo State, starting from a joint and coordinated effort among universities, municipalities and the environmental protection agency, in cooperation with the existing conventional air quality monitoring network. This initiative will allow for another step in the universalization of natural and social environment care, promoting and guaranteeing improvement in the quality of life of current and future societies.

Keywords: vegetal bioindicator, air pollution, environmental risk evaluation, biomonitoring. 


\section{RESUMEN}

CARNEIRO, R.M.A. Bioindicadores vegetales de polución atmosférica: una contribución para la salud de la comunidad. 2004. 146 p. Disertación (Maestría) - Escuela de Enfermería de Ribeirão Preto, Universidad de São Paulo, Ribeirão Preto.

La calidad del aire en áreas urbanas e industriales tiende a presentar concentraciones indeseables de contaminantes, sin que exista un sistema integral de monitoreo, dada la sofisticación de los métodos físico-químicos convencionales, que requieren costos elevados de implantación, operación y manutención, costos que pueden ser minimizados por la adopción de metodología complementar de biomonitorización. La biomonitorización es un método experimental que permite evaluar la respuesta de organismos vivos ante la polución, ofreciendo ventajas como: costos reducidos, eficiencia para el monitoreo de áreas amplias y por largos períodos de tiempo y, también, evaluación de elementos químicos en bajas concentraciones ambientales. Las medidas y registros efectuados por redes convencionales de monitoreo de la calidad Del aire permiten verificar si normas y limites establecidos o recomendados por la legislación, agencias ambientales y órganos de promoción de la salud humana están siendo respetados. Entre tanto, tales mediciones no permiten conclusiones inmediatas sobre las consecuencias de poluentes en los seres vivos. Así, la biomonitorización debe ser considerada como un método complementar en el análisis de poluentes, pudiendo constituirse en un tercer sistema de informaciones, además de los inventarios de emisiones y de concentraciones ambientales. El presente trabajo tuvo por objetivo identificar especies vegetales (vasculares, musgos y líquenes) utilizadas como bioindicadores y su relación con poluentes atmosféricos, por medio de una revisión sistemática de literatura, en estudios experimentales y observacionales, referente al período de enero de 1997 a junio de 2003. De un total de 4547 trabajos científicos sobre bioindicadores, fueron preseleccionados 279 estudios referentes al uso de vegetales bioindicadores de polución atmosférica, publicados en los idiomas inglés, español y portugués. Estos trabajos fueron analizados por la aplicación de dos testes de relevancia, seleccionándose 240 referencias y obtenidos 154 estudios en la íntegra. De este total, fueron incluidos, después de la aplicación de los dos testes de relevancia, 126 trabajos científicos, sobre el tema considerado, realizados en 34 países diferentes. Se constató que el uso de la metodología de revisión sistemática permitió levantar el conocimiento de las experiencias académicas en esta área de estudio, ampliando el conocimiento sobre ese tema. Los resultados revelaron la utilización de 111 especies vegetales, siendo 63 especies pertenecientes a la división Angiospermae; 11 especies de la división Coniferophyta; 15 especies de musgos y 22 especies de líquenes, relacionadas al monitoreo de uno o más de los siguientes poluentes atmosféricos: metales pesados, ozono, material particulado, dióxido de azufre, óxidos de nitrógeno, monóxido de carbono, fluoretos, compuestos orgánicos volátiles. Se constató, así, la existencia de una cantidad significativa de estudios de esa naturaleza, principalmente en los países europeos, donde está implantado el proyecto EUROBIONET de biomonitorización de polución atmosférica, basado en la estandarización de ensayos y biomonitores, desde el año 2000. Teniendo en vista que determinados bioindicadores ya están consagrados o validados para el monitoreo de poluentes atmosféricos específicos, se considera posible la instalación de una red de biomonitorización ambiental en el Estado de São Paulo, a partir de un trabajo conjunto y coordinado entre universidades, municipios y la agencia de protección ambiental, asociada a la red existente de control convencional de la calidad del aire. Tal iniciativa permitirá un avanzo en la universalización de los cuidados con los ambientes natural y social, promoviendo y garantizando mejoras en el patrón de calidad de vida de las sociedades actuales y futuras.

Uní términos: bioindicador vegetal, polución atmosférica, evaluación de riesgo ambiental, biomonitorización. 
Dedico este trabalho à construção de um Mundo Bem Melhor. 
“Ao atingirmos um objetivo, sempre queremos atingir outro, e assim é o processo Vida. Nela, ou você atinge o alvo final, ou você começa outro processo. A vida é o conjunto de processos, experiências, para se atingir os alvos. Você aprende até o último instante. Cada vez que você aprende, você cria ilusão para aprender mais. Nunca se pára de aprender. Com isso você ganha amor à Vida. Se isso é verdade para você, você não pode parar. A felicidade está em cada alvo que você alcança e nos processos que você percorre para alcançar o alvo. Para haver felicidade, é preciso ter objetivo. Se você não tem objetivo, você se queixa e se degenera. Cai na futilidade. (...) O mecanismo filosófico do progresso são os objetivos em processos consecutivos. Quando você começar a se deprimir, arranje um objetivo. De repente, você esbarrará com o grande Objetivo. Ingressará em um novo mundo!” 


\section{LISTA DE ABREVIATURAS E SIGLAS}

AA

AFA

BA

BETEX

CAPES

CETEST

CONAMA

CV.

DIRP

ERL

ES

EUA

FDI

GEEs

GO

IAP

IBCT

IPNI

IQA

LPAE
Ácido ascórbico

Associação Florestal Americana

Bahia

Benzeno, Tolueno, Etil-benzeno, Xileno

Coordenadoria de Aperfeiçoamento de Pessoal de Nível Superior

Companhia de Tecnologia de Saneamento Ambiental

Conselho Nacional do Meio Ambiente

cultivar agrícola

Distrito Industrial de Ribeirão Preto

Eletronic Reference Library

Espírito Santo

Estados Unidos da América

Índice de Danos Foliares

Gases do Efeito Estufa

Goiás

Índice de Pureza Atmosférica

Instituto Brasileiro de Informações em Ciência Tecnológicas

International Plant Name Index

Índice de Qualidade do Ar

Laboratório de Poluição Atmosférica Experimental da Faculdade de Medicina - USP 


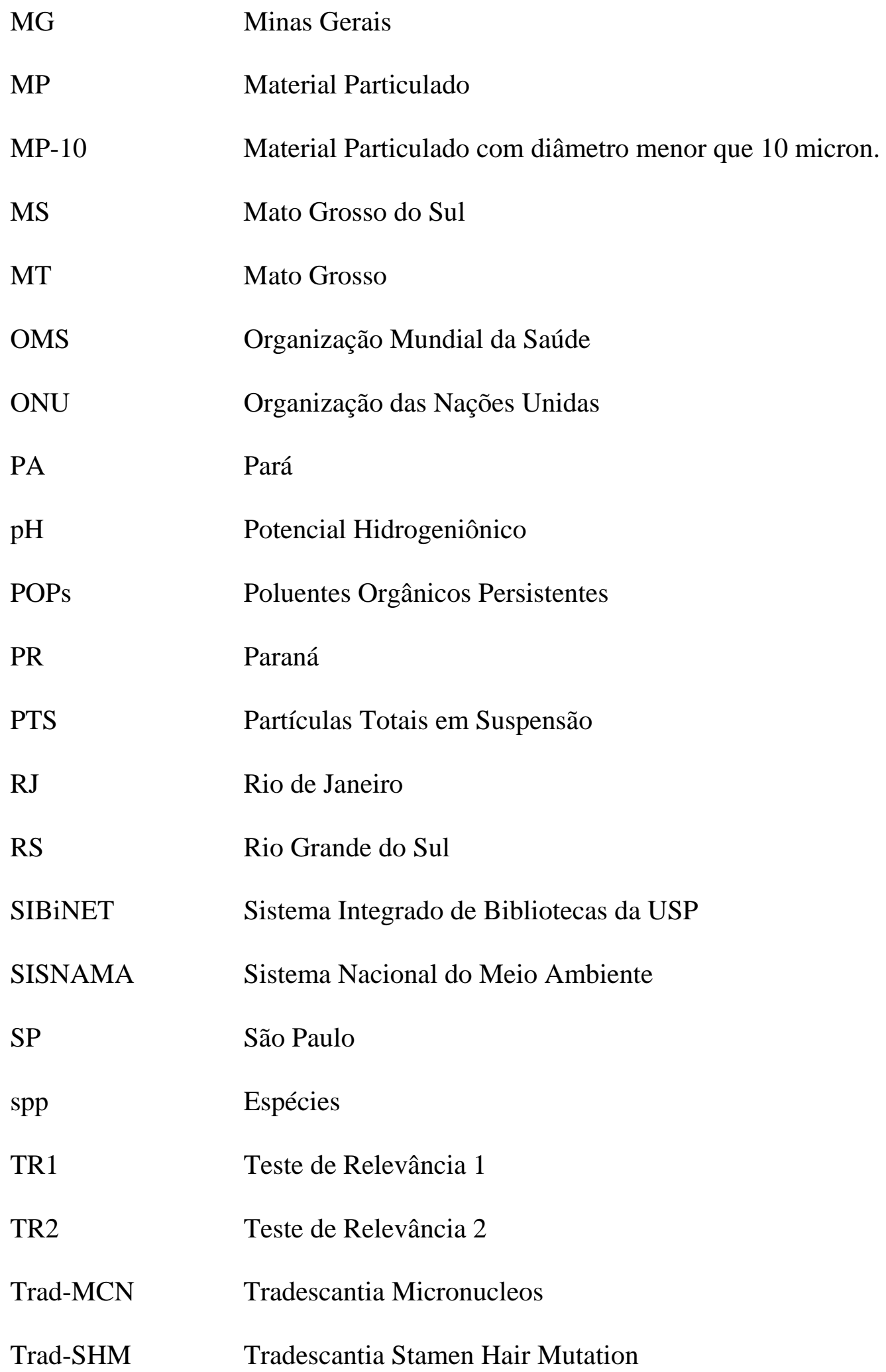


TLD Transporte de poluentes de grandes distâncias

USEPA United States Environmental Pollution Agency

USP Universidade de São Paulo

V.I.I. Índice de Injúrias Visíveis

VOCs Compostos Orgânicos Voláteis

WHO World Health Organization

conclusão 


\section{LISTA DE SÍMBOLOS DE ELEMENTOS E SUBSTÂNCIAS QUÍMICAS}

\begin{tabular}{|c|c|}
\hline $\mathrm{Al}$ & Alumínio \\
\hline As & Arsênio \\
\hline B & Boro \\
\hline $\mathrm{Ba}$ & Bário \\
\hline $\mathrm{C}$ & Carbono \\
\hline $\mathrm{Ca}$ & Cálcio \\
\hline $\mathrm{Cd}$ & Cádmio \\
\hline $\mathrm{Ce}$ & Cério \\
\hline $\mathrm{CO}$ & Monóxido de carbono \\
\hline Co & Cobalto \\
\hline $\mathrm{CO}_{2}$ & Dióxido de carbono \\
\hline $\mathrm{Cr}$ & Cromo \\
\hline Cs & Césio \\
\hline $\mathrm{Cu}$ & Cobre \\
\hline $\mathrm{F}$ & Flúor \\
\hline $\mathrm{Fe}$ & Ferro \\
\hline $\mathrm{Ga}$ & Gálio \\
\hline $\mathrm{Ge}$ & Germânio \\
\hline $\mathrm{H}_{2} \mathrm{SO}_{4}$ & Ácido sulfúrico \\
\hline $\mathrm{HCl}$ & Ácido clorídrico \\
\hline $\mathrm{HF}$ & Gás fluorídrico \\
\hline
\end{tabular}


Hf

Hg

$\mathrm{HNO}_{3}$

K

La

$\mathrm{Li}$

Mg

Mn

Mo

$\mathrm{N}$

$\mathrm{Na}$

$\mathrm{NH}_{3}$

$\mathrm{Ni}$

NO

$\mathrm{NO}_{2}$

NOx

$\mathrm{O}$

$\mathrm{O}_{3}$

P

$\mathrm{Pb}$

$\mathrm{Rb}$
Háfnio

Mercúrio

Ácido nítrico

Potássio

Lantânio

Lítio

Magnésio

Manganês

Molibdênio

Nitrogênio

Sódio

Amônia

Níquel

Óxido nítrico

Dióxido de nitrogênio

Óxidos de nitrogênio

Oxigênio

Ozônio

Fósforo

Chumbo

Rubídio 
S

$\mathrm{Sb}$

Sc

Se

Si

$\mathrm{SO}_{2}$

$\mathrm{Sr}$

$\mathrm{Te}$

Th

$\mathrm{Ti}$

$\mathrm{U}$

V

W

$\mathrm{Zn}$

MMT

PAHs

PAN

PCBs

VOCs
Enxofre

Antimônio

Escândio

Selênio

Silício

Dióxido de enxofre

Estrôncio

Telúrio

Tório

Titânio

Urânio

Vanádio

Tungstenio

Zinco

Metil ciclopentadienil tricarbonil (derivado orgânico Mn)

Hidrocarbonetos policíclicos aromáticos

Peroxi-acetil-nitrato

Bifenilpoliclorados

Compostos orgânicos voláteis 


\section{INTRODUÇÃO}

\subsection{Saúde, ambiente e desenvolvimento}

Nas duas últimas décadas do século XX, os conceitos de qualidade de vida e de qualidade ambiental passaram a ter um maior destaque nos meios técnicos e científicos, ao lado dos cuidados direcionados ao meio ambiente e seus recursos naturais, como forma de se garantir melhores condições de vida às gerações futuras.

Além desses fatores, questões de ordem econômica e social têm atraído a atenção dos principais agentes políticos, favorecendo a promoção da qualidade de vida ou, no mínimo, de uma maior conscientização sobre a importância da qualidade ambiental para a saúde humana.

Grandes centros urbanos normalmente oferecem condições desfavoráveis para uma qualidade de vida saudável, pelo contexto geral vivido no seu cotidiano, como: trânsito intenso; rios, solos e ar poluídos por lançamentos de efluentes e/ou resíduos sólidos domésticos e industriais; problemas com a oferta de água potável; queimadas urbanas; e, tantos outros problemas que vêm sendo enfrentados. Esta situação vem merecendo maior atenção pela estreita relação com a saúde humana, além dos fatores já classicamente admitidos em saúde pública, tais como: veiculação de doenças por água, esgoto e lixo, verduras e alimentos contaminados e a presença de vetores no espaço urbano (FORATINI, 1992). 
A industrialização é reconhecida como fator preponderante na degradação ambiental do planeta; degradação do solo, água e ar que ocorreram em escala exponencial, a partir da revolução industrial (BRAGA et al., 2002; TORRES, 1996; VEGARA, 2002).

O modelo econômico atual possui características evidentes de insustentabilidade, pelo grau de degradação ambiental gerada, podendo tornar-se alarmante, caso os países em desenvolvimento procurarem atingir os mesmos padrões de produção e consumo observados nos países desenvolvidos. Os interesses econômicos, que muitas vezes são conflitantes com as questões ambientais, direcionam uma maior parcela de recursos financeiros para os setores produtivos da sociedade. A curto prazo, alguns poucos são beneficiados com estes modelos econômicos. Entretanto, em longo prazo, todos perdem, tendo em vista as conseqüências globais das ações decorrentes de um processo de desenvolvimento ambientalmente desequilibrado (MARTINE, 1996).

O crescimento econômico ilimitado gera processos de desequilíbrio, com conseqüências graves à saúde física e psicológica humana, além de perturbações dos processos ecológicos que degradam o ambiente e afetam a qualidade de vida, estando a ganância no âmago do problema (VILELA; MENDES, 2000).

No Brasil e em países da América Latina, fatores como: má distribuição de renda, analfabetismo ou pouca escolaridade, condições precárias de habitação e degradação ambiental exercem papel importante nas condições de vida e saúde (BUSS, 2000).

A indústria brasileira de transformação sofreu uma mudança considerável em sua estrutura, a partir da década de 70 do séc. XX, direcionando-se para uma forma de produção mais suja e intensiva em recursos naturais. O impacto dessa alteração no padrão de produção pode ser observado a partir do momento em que o país passou de importador para exportador de produtos intermediários - minerais não metálicos, papel e papelão, metalurgia e química, cujas indústrias são consideradas mais poluentes que a média das indústrias de transformação. 
Também a desconcentração espacial da indústria de bens intermediários, para a periferia brasileira, vem determinando a ampliação territorial de seus efeitos sobre o ambiente (TORRES, 1996).

A contaminação e a poluição do ambiente podem ser percebidas nos níveis locais, regionais e globais, sendo que os efeitos da contaminação do solo, do ar e da água se espalham territorialmente, podendo ser sentidos em áreas vizinhas, que muitas vezes não abrigam as fontes de emissão. Esta condição tem sido, muitas vezes, geradora de conflitos entre municípios, estados e nações (BRAGA et al., 2002; CETESB, 1999).

No Brasil, recentemente, foi possível observar danos ambientais abrangendo uma região extensa, quando corpos d'água dos estados de Minas Gerais e Rio de Janeiro foram gravemente contaminados por lançamentos irregulares de substâncias químicas da Indústria Cataguases de Papel, Cataguases, MG. Como conseqüência, além dos danos ambientais, diversos municípios mineiros e fluminenses tiveram o abastecimento de água domiciliar, industrial e agrícola suspensos, comprometendo a saúde e bem-estar da população atingida, bem como a economia local (FOLHA, 2003).

A Conferência das Nações Unidas sobre Meio Ambiente e Desenvolvimento, realizada na cidade do Rio de Janeiro de 3 a 14 de junho de 1992, declarou que para alcançar o desenvolvimento sustentável, a proteção ambiental deve constituir parte integrante do processo de desenvolvimento, sendo necessário colocar os seres humanos no centro das preocupações, no que diz respeito ao desenvolvimento sustentado, e que o direito ao desenvolvimento deve ser alcançado de forma a garantir as necessidades das gerações presentes e futuras (ONU, 1992).

Os problemas de saúde ligados à poluição do meio ambiente têm sido cada vez mais pesquisados por cientistas e acompanhados pelos setores públicos, constituindo a base da Saúde Ambiental e inserindo-se na pauta de formulação de políticas que busquem a promoção 
da saúde, a partir da melhoria das condições de vida social e ambiental (BRESLOW, 1999; ONU, 1992; SHEN et al., 1998; WHO,1986).

O conceito de promoção de saúde foi formulado e difundido a partir da Carta de Ottawa, produzida durante a I Conferência Internacional sobre Promoção da Saúde, promovida pela Organização Mundial da Saúde, em 1986, no Canadá, trazendo uma nova concepção de saúde, baseada em novos fatores (BUSS, 2000; VILELA; MENDES, 2000; WESTPHAL, 1997).

Nessa Carta, o conceito de promoção de saúde passa a estar associado a valores como: qualidade de vida, saúde, solidariedade, equidade, democracia, cidadania, desenvolvimento, participação e parceria, entre outros. Sua implementação vincula-se a estratégias de atuação combinadas: ação do Estado, através de políticas públicas saudáveis; reforço da ação comunitária; desenvolvimento de habilidades pessoais; reorientação do sistema de saúde; e parcerias intersetoriais (BUSS, 2000; VILELA; MENDES, 2000).

Assim, promover saúde também significa garantir que as condições ambientais não ameacem os processos vitais, pela emissão descontrolada de contaminantes no solo, água e ar ou pelo esgotamento dos recursos naturais. Tais processos fatalmente repercutem e repercutirão sobre a saúde humana, como tem sido mais recentemente diagnosticado pelos centros de difusão de conhecimentos comprometidos com uma nova perspectiva de vida no planeta.

Destaca-se, portanto, a necessidade do aprofundamento de discussões e implementação de ações que priorizem a melhoria da qualidade de vida, nos seus aspectos de saúde e ambiente, principalmente nos países em desenvolvimento, sendo considerados a vulnerabilidade do modelo econômico vigente e a necessidade de mudanças estruturais no padrão de desenvolvimento atual (MARTINE, 1996). 


\subsection{Poluição atmosférica}

Dentre os diferentes tipos de poluição observados no ambiente, a contaminação do ar tem sido um dos temas de grande interesse para o meio científico nas últimas décadas, tendo em vista sua implicação negativa sobre a saúde humana, ecossistemas e bens construídos, caracterizando-se como um fator de importância na busca da implementação do desenvolvimento sustentável (BRAGA et al., 2002; CAMPOS, 2002; SALDIVA, 1997; CETESB, 1999).

\subsubsection{Poluentes atmosféricos}

A avaliação dos problemas de contaminação do ar teve início nas áreas próximas de fontes industriais, passando pela avaliação de emissões nos grandes centros urbanos, pelo transporte entre regiões, até chegar a avaliação de contaminações em escala global como, os efeitos da poluição sobre a camada de ozônio na estratosfera, atualmente relacionada às alterações climáticas no planeta (CETESB, 1999).

As fontes emissoras de contaminantes atmosféricos são classificadas em estacionárias ou móveis. As principais fontes estacionárias estão ligadas a processos de combustão decorrentes da produção industrial, de usinas termoelétricas ou da queima de resíduos sólidos, em serviços urbanos de tratamento de resíduos. Quanto às fontes móveis, são representadas, principalmente, pelos veículos automotores (BRASIL, 1990; CETESB, 2002).

Classicamente, os poluentes atmosféricos são divididos em duas categorias: poluentes primários, quando emitidos diretamente pelas fontes; e poluentes secundários, formados por reações químicas entre poluentes primários e outros constituintes da atmosfera (BRAGA et al., 2002; BRASIL, 1990; CAMPOS, 2002). 
A determinação sistemática da qualidade do ar deve limitar-se a um número restrito de contaminantes, definidos em função de sua importância e dos recursos materiais e humanos disponíveis, constituindo-se nos indicadores da qualidade do ar consagrados universalmente (CETESB, 2002).

No Estado de São Paulo, a agência de controle ambiental, Companhia de Tecnologia de Saneamento Ambiental - CETESB, estabelece os seguintes indicadores da qualidade do ar: a) Partículas totais em suspensão (PTS): de composição variada, incluindo metais pesados. Material sólido ou líquido suspenso no ar na forma de poeira, neblina, aerossol, fumaça, fuligem, com dimensões inferiores a 100 micrometros. São produzidas por indústrias, veículos, suspensão do solo, queimadas;

b) Material particulado ou partículas inaláveis $\left(\mathrm{MP}_{10}\right)$ : material sólido ou líquido suspenso no ar, na forma de poeira, neblina, aerossol, fumaça, fuligem, com dimensões inferiores a 10 micrometros. São produzidos nos processos de combustão industriais e veiculares;

c) Dióxido de enxofre $\left(\mathrm{SO}_{2}\right)$ : gás incolor, de odor forte. Precursor dos sulfatos e um dos principais componentes das partículas inaláveis $\left(\mathrm{MP}_{10}\right)$. É produzido na queima de óleo combustível, em refinarias de petróleo e indústrias de papel. É o principal responsável pelas doenças respiratórias provocadas por poluentes atmosféricos e pelo agravamento de doenças cardíacas;

d) Dióxido de nitrogênio $\left(\mathrm{NO}_{2}\right)$ : gás marrom avermelhado, de odor forte e irritante. Pode levar à formação do ácido nítrico, nitratos e compostos orgânicos tóxicos. Produzido na combustão veicular, em processos industriais e de incineração, em condições de temperaturas elevadas. Favorece a ocorrência de infecções respiratórias e provoca danos à vegetação, em decorrência da formação de chuva ácida. Além do $\mathrm{NO}_{2}$, outros óxidos de nitrogênio fazem parte do grupo genericamente chamado de NOx, tais como: o óxido 
nitroso $\left(\mathrm{N}_{2} \mathrm{O}\right)$, que se destaca na ciclagem do nitrogênio, e o $\mathrm{NO}$, que é tóxico e precursor do $\mathrm{NO}_{2}$;

e) Monóxido de carbono (CO): gás incolor, inodoro, insípido, formado na combustão incompleta em veículos. Na presença de oxigênio molecular, forma o dióxido de carbono, que contribui com o "efeito estufa", responsável pela elevação das temperaturas do planeta;

f) Ozônio $\left(\mathrm{O}_{3}\right)$ : poluente secundário, formado por ação fotoquímica, a partir dos óxidos de nitrogênio. Gás incolor e inodoro nas concentrações ambientais. Provoca irritação dos olhos e das vias respiratórias, além de causar danos a plantios e vegetação em geral (CETESB, 2002).

De acordo com Derisio (2000); Braga et al. (2002) e Baird (2002) outros contaminantes são, também, indicados como importantes modificadores da qualidade do ar, entre os quais destacam-se:

a) Compostos orgânicos voláteis (VOCs) e hidrocarbonetos: formados a partir de eventos naturais, na decomposição e queima de matéria orgânica ou eventos antrópicos, na combustão incompleta de combustíveis fósseis, evaporação de solventes e de combustíveis armazenados;

b) Poluentes metálicos: Chumbo $(\mathrm{Pb})$ presente na gasolina, Mercúrio $(\mathrm{Hg})$ e aqueles desprendidos durante a queima de carvão mineral, ou em processos industriais envolvendo temperaturas elevadas;

c) Gás fluodrídrico (HF) e demais fluoretos gasosos, emitidos pelas indústrias de fertilizantes, na produção do alumínio e em refinarias de processamento de matériasprimas que contenham flúor, em altas temperaturas. São irritantes respiratórios e com ação desfoliante sobre a vegetação. 
Ainda que uma das principais fontes de poluição atmosférica contemporânea seja os combustíveis líquidos, não são os contaminantes primários emitidos diretamente na atmosfera pelos veículos automotores os que mais contribuem para a poluição atmosférica, mas sim os contaminantes secundários, resultando no smog fotoquímico como o ozônio e peroxiacetil nitratos - PAN (ALVES et al., 2001; ANDREWS; BRIMBLECOMB; JICKELLS, 1996; CAMPOS, 2002).

Em elevadas temperaturas, como durante o processo de combustão, o oxigênio do ar pode reagir com o nitrogênio molecular, formando o monóxido de nitrogênio (NO). A oxidação do NO dá-se pela reação com hidrocarbonetos voláteis (etileno, butano etc), formando o dióxido de nitrogênio $\left(\mathrm{NO}_{2}\right)$. Este gás, por sua vez, na presença de radiação ultravioleta com comprimento de onda menor que 310 microm., é dissociado em NO e oxigênio molecular $(\mathrm{O})$, tornando possível a formação do ozônio $\left(\mathrm{O}_{3}\right)$, contaminante secundário (ANDREWS; BRIMBLECOMB; JICKELLS, 1996; CAMPOS, 2002).

As concentrações de $\mathrm{NO}, \mathrm{NO}_{2}$ e $\mathrm{O}_{3}$ variam no decorrer do dia, em situações de smog fotoquimíco, de tal forma que o $\mathrm{O}_{3}$ começa a ter sua concentração aumentada no início da manhã, com pico no meio da tarde, estendendo-se até o início da noite. Já o $\mathrm{NO}_{2}$ mantém concentrações pouco variáveis no decorrer do dia e o NO apresenta-se com maiores concentrações no período da manhã (OLCESE; TOSELLI, 2002; CAMPO, 2002).

Em cidades que possuem uma grande frota automotiva, é comum a ocorrência de uma espécie de névoa marrom, decorrente de altas concentrações de $\mathrm{NOx}$ e de $\mathrm{MP}_{10}$ na atmosfera. Em circunstâncias de muita névoa, a formação do ozônio como contaminante secundário diminui, visto que ocorre uma menor incidência de luz solar (ANDREWS; BRIMBLECOMB; JICKELLS, 1996; CAMPOS, 2002; OLCESE; TOSELLI, 2002).

Nos períodos de inverno, quando as inversões térmicas são favorecidas pela chegada brusca de massas de ar frias, estas névoas com temperaturas mais elevadas ficam retidas nas 
altitudes mais baixas da atmosfera, piorando significativamente a qualidade do ar em áreas urbanas adensadas (CAMPOS, 2002; CETESB, 2002).

Outro problema grave enfrentado pelos países desenvolvidos, desde a metade do século passado, e mais recentemente nos países em desenvolvimento, é a presença de ácidos na composição da chuva, decorrentes de atividades antrópicas. Os ácidos sulfúrico $\left(\mathrm{H}_{2} \mathrm{SO}_{4}\right)$, nítrico $\left(\mathrm{HNO}_{3}\right)$ e clorídrico $(\mathrm{HCl})$ produzidos na queima de combustíveis fósseis, bem como aqueles com origem biogênica, formam aerossóis que atuam como núcleos de condensação de nuvens, o que interfere na composição da água de chuva (ANDREWS; BRIMBLECOMB; JICKELLS, 1996; CAMPOS, 2002).

Ainda, segundo esses autores, a solubilidade desses ácidos com a água determina o seu tempo de residência na atmosfera, contribuindo em maior ou menor grau com a acidez da chuva:

- $\mathrm{O} \mathrm{HCl}$ é bastante solúvel em água e, conseqüentemente, tem um curto período de residência na atmosfera, tornando-se importante na acidificação de chuvas próximas à fonte emissora;

- $\mathrm{O} \mathrm{NO} 2$ é importante, também, para as regiões mais distantes da fonte, pois o ácido $\mathrm{HNO}_{3}$ apresenta um tempo de residência de 5 a 6 dias;

- $\mathrm{O} \mathrm{SO}_{2}$ é encontrado na composição das chuvas há centenas de quilômetros da fonte emissora.

A acidez da chuva pode levar à corrosão de metais e ao desgaste de materiais de construção; pode causar a lixiviação de cátions do solo e a alterações nos processos fisiológicos das plantas, pela lixiviação de nutrientes. Nos corpos d'água, chuvas ácidas podem acarretar na morte de peixes e na modificação daquele ecossistema (ANDREWS; BRIMBLECOMB; JICKELLS, 1996; CAMPOS, 2002). 
Fluoretos gasosos, particularmente o HF, grupo de poluentes atmosféricos de elevada fitotoxicidade, provocaram ações devastadoras sobre a vegetação natural dos países industrializados do hemisfério Norte.

Mais recentemente, devido à transferência dessas atividades poluentes para os países em desenvolvimento e à crescente industrialização neles observada, o mesmo problema tem acometido os países do terceiro mundo, a exemplo dos danos ocorridos à vegetação que recobria o trecho da Serra do Mar, situado na zona de influência do Complexo Industrial de Cubatão, Brasil, a partir da época de sua implantação, na década de 50 do séc. XX, referidos por Klumpp, Domingos e Klumpp (1996).

Os VOCs são encontrados em emissões geradas pela queima de carvão mineral e demais combustíveis fósseis, bem como em decorrência da evaporação de combustíveis líquidos em postos de abastecimento, nos centros urbanos. Merecem especial atenção porque, na presença de luz solar, reagem quimicamente com $\mathrm{NOx}$, formando $\mathrm{O}_{3}$ e outros componentes do smog fotoquímico (USEPA, 2004a).

A poluição por hidrocarbonetos ocorre quando combustíveis fósseis são queimados parcialmente, sendo eliminados pelo sistema de exaustão dos veículos, ou quando evaporam diretamente para a atmosfera, de reservatórios onde são armazenados. No grupo dos hidrocarbonetos encontram-se muitos compostos tóxicos que podem causar danos graves à saúde humana. Podem apresentar-se na forma de gases ou partículas em suspensão, emitidos por uma grande variedade de processos naturais e industriais e, principalmente, por veículos motorizados como carros, caminhões e ônibus (USEPA, 2004b).

A presença de hidrocarbonetos policíclicos aromáticos (PAHs) na baixa atmosfera é um importante aspecto de poluição ambiental, já que muitos de seus componentes são mutagênicos e cancerígenos. Uma das mais importantes fontes deste poluente é o tráfego de veículos, principalmente nas grandes cidades. Já em cidades do hemisfério Norte, as maiores 
concentrações de PAHs ocorrem no período de inverno, em decorrência da queima de combustíveis fósseis e lenha, em sistemas de aquecimento domiciliares (LODOVICI et al., 1998).

\subsubsection{Poluição atmosférica e saúde humana}

Os problemas decorrentes da poluição atmosférica sobre a saúde humana têm sido considerados em estudos de saúde pública, de saúde ambiental e de toxicologia, apontando para efeitos que se manifestam principalmente por doenças crônicas, prejudicando a qualidade de vida das populações afetadas ou causando aumento de mortalidade, em situações extremas (PEITER; TOBAR, 1998).

No Canadá, em pesquisa realizada com aproximadamente 1200 usuários do Serviço Público de Saúde de Ontario, localizados nas proximidades de estações de Avaliação da Qualidade do Ar, verificou-se o aumento da procura por atendimento médico em ocasiões de acréscimo no nível médio de $\mathrm{SO}_{2}$ presente no ar (PENGELLY, 1992).

No Brasil, pesquisadores do Laboratório de Poluição Atmosférica Experimental (LPAE) da Faculdade de Medicina da Universidade de São Paulo, USP, relacionaram a ocorrência de concentrações elevadas de $\mathrm{NO}_{\mathrm{x}}$ no ar, com a incidência de mortalidade infantil por doenças respiratórias, na cidade de São Paulo. Os autores destacaram que esta correlação ainda não havia sido registrada, sendo mais freqüente a correlação entre mortalidade infantil e material particulado e $\mathrm{SO}_{2}$ (SALDIVA et al., 1994).

Duchiade (1992) destaca três tipos principais de reação do sistema respiratório aos poluentes, por indivíduos humanos:

a) efeitos agudos em pessoas sadias em episódios de smog ou de aumento súbito de poluição atmosférica; 
b) exacerbação de doenças pré-existentes em indivíduos vulneráveis, com cardiopatias e doenças respiratórias prévias; e,

c) fenômeno de hipersensibilidade de origem imunológica ou hiperreatividade brônquica, por causarem danos reversíveis e problemas crônicos.

Muitas pesquisas analíticas têm demonstrado que na composição atmosférica de centros urbanos, particularmente nas áreas de intenso tráfego, estão presentes substâncias mutagêgicas e carcinogênicas, incluindo compostos orgânicos como o benzeno, compostos inorgânicos contendo níquel e cromo, e radionúcleos. O monitoramento da atmosfera urbana para micropoluentes genotóxidos, além dos poluentes convencionais, tem recebido crescente consideração, com o objetivo de avaliar riscos potenciais à saúde humana (MONARCA et al., 1999).

Apesar de ser conhecido o efeito negativo da poluição do ar sobre a saúde humana, é difícil e onerosa a comprovação de conexão entre um certo poluente e uma doença. Esta conexão pode ser verificada com base em dados sobre a poluição atmosférica e a incidência da doença em uma certa região (PEITER; TOBAR, 1998; WAPPELHORST et al., 2000).

\subsubsection{Legislação sobre qualidade do ar}

O controle da qualidade do ar é tema de grande importância para os principais organismos internacionais e nacionais de saúde, que estabelecem normas, padrões e recomendações nessa área.

A Organização Mundial da Saúde (OMS) recomenda limites máximos de concentração de alguns contaminantes presentes na atmosfera, como $\mathrm{SO}_{2}, \mathrm{NO}_{2}, \mathrm{CO}$ e $\mathrm{O}_{3}$, conforme apresentado no Quadro 1. 
Quadro 1 - Limites máximos de concentração de alguns contaminantes presentes na atmosfera recomendados pela Organização Mundial da Saúde - 1995

\begin{tabular}{|c|c|c|}
\hline Contaminante & Concentração & Tempo de amostragem \\
\hline Dióxido de enxofre $\left(\mathrm{SO}_{2}\right)$ & $125 \mu \mathrm{g} / \mathrm{m}^{3}$ & 24 horas \\
\hline Dióxido de nitrogênio $\left(\mathrm{NO}_{2}\right)$ & $200 \mu \mathrm{g} / \mathrm{m}^{3}$ & 1 hora \\
\hline Monóxido de carbono $(\mathrm{CO})$ & $10 \mathrm{mg} / \mathrm{m}^{3}$ & 8 horas \\
\hline Ozônio $\left(\mathrm{O}_{3}\right)$ & $120 \mu \mathrm{g} / \mathrm{m}^{3}$ & 8 \\
\hline
\end{tabular}

Fonte: CETESB, 2002

\section{a) Legislação Federal sobre Padrões de Qualidade do Ar}

A legislação brasileira trata de forma ampla a problemática da poluição atmosférica, abordando desde padrões de qualidade do ar e padrões de emissão veiculares e industriais, até processos de licenciamento e implantação de fontes estacionárias de emissão atmosférica.

A Lei Federal n. ${ }^{\circ} 6.938 / 1981$ define as regras gerais para políticas ambientais, para o sistema de licenciamento e cria o Conselho Nacional do Meio Ambiente - CONAMA, que tem a responsabilidade de estabelecer os padrões e métodos ambientais (BRASIL, 1981).

A Resolução CONAMA n. ${ }^{\circ} 01$ de 23/01/86 exige que, na implantação de Distritos Industriais seja elaborado o Estudo de Impacto Ambiental e respectivo Relatório de Impacto Ambiental, de forma a avaliar os riscos decorrentes da implantação de empreendimentos potencialmente poluidores e as formas de minimizar ou compensar os danos ao meio ambiente e comunidades circunvizinhas (BRASIL, 1986).

A Portaria do Ministério do Interior n. ${ }^{\circ} 231 / 76$ (CETESB, 1999) fixou os padrões de qualidade do ar para material particulado, dióxido de enxofre, monóxido de carbono e oxidantes, estabelecendo que os padrões de emissão deviam ser definidos pelos Estados.

De acordo com a Resolução CONAMA n. ${ }^{\circ}$ 03/90, são considerados padrões de qualidade do ar as concentrações de poluentes atmosféricos que, se ultrapassadas, poderão 
afetar a saúde, a segurança e o bem-estar da população, bem como ocasionar danos à flora e à fauna, aos materiais e ao meio ambiente em geral (BRASIL, 1990).

Essa Resolução define poluente atmosférico como sendo

(...) qualquer forma de matéria ou energia com intensidade e em quantidade, concentração, tempo ou características em desacordo com os níveis estabelecidos, e que tornem ou possam tornar o ar:

I - impróprio, nocivo ou ofensivo à saúde;

II - inconveniente ao bem-estar público;

III - danoso aos materiais, à fauna e flora;

IV - prejudicial à segurança, ao uso e gozo da propriedade e às atividades normais da comunidade.

Também no artigo $2^{\circ}$, a mesma resolução estabelece os conceitos de:

a) Padrões Primários de Qualidade do Ar: concentrações de poluentes que, se ultrapassadas, poderão afetar a saúde da população;

b) Padrões Secundários de Qualidade do Ar: concentrações de poluentes abaixo das quais prevê-se o mínimo efeito adverso sobre o bem-estar da população, assim como o mínimo dano à fauna, à flora, aos materiais e ao meio ambiente em geral.

Os valores numéricos dos padrões primário e secundário de qualidade do ar, bem como os métodos de medição, conforme estabelece a Resolução CONAMA n. ${ }^{\circ}$ 03/90 são apresentados no Quadro 2 (BRASIL, 1990). 
Quadro 2 - Padrões Primário e Secundário de qualidade do ar e métodos de medição, segundo Resolução CONAMA n. ${ }^{0}$ 03/90

\begin{tabular}{|c|c|c|c|c|}
\hline Parâmetro & Amostragem & $\begin{array}{c}\text { Primário } \\
\mu \mathrm{g} / \mathrm{m}^{3}\end{array}$ & $\begin{array}{c}\text { Secundário } \\
\mu \mathrm{g} / \mathrm{m}^{3}\end{array}$ & Medição \\
\hline $\begin{array}{l}\text { Partículas totais em } \\
\text { suspensão (PTS) }\end{array}$ & $\begin{array}{l}24 \mathrm{~h}^{1} \\
\mathrm{mga}^{2}\end{array}$ & $\begin{array}{l}240 \\
80\end{array}$ & $\begin{array}{l}150 \\
60\end{array}$ & $\begin{array}{c}\text { Amostrador de grandes } \\
\text { volumes }\end{array}$ \\
\hline Material particulado (MP-10) & $\begin{array}{l}24 \mathrm{~h}^{1} \\
\operatorname{maa}^{3}\end{array}$ & $\begin{array}{l}150 \\
50\end{array}$ & $\begin{array}{l}150 \\
50\end{array}$ & $\begin{array}{c}\text { Separação } \\
\text { Inércia/filtração }\end{array}$ \\
\hline Fumaça & $\begin{array}{l}24 \mathrm{~h}^{1} \\
\mathrm{maa}^{3}\end{array}$ & $\begin{array}{l}150 \\
60\end{array}$ & $\begin{array}{l}100 \\
40\end{array}$ & Refletância \\
\hline $\mathrm{SO}_{2}$ & $\begin{array}{l}24 \mathrm{~h}^{1} \\
\mathrm{maa}^{3}\end{array}$ & $\begin{array}{l}365 \\
80\end{array}$ & $\begin{array}{l}100 \\
40\end{array}$ & Pararosanilina \\
\hline $\mathrm{NO}_{2}$ & $\begin{array}{l}1 \mathrm{~h}^{1} \\
\mathrm{maa}^{3}\end{array}$ & $\begin{array}{l}320 \\
100\end{array}$ & $\begin{array}{l}190 \\
100\end{array}$ & Quimiluminescência \\
\hline $\mathrm{CO}$ & $1 \mathrm{~h}$ & $\begin{array}{l}40.000 \\
35 \mathrm{ppm} \\
10.000 \\
9 \mathrm{ppm}\end{array}$ & $\begin{array}{l}40.000 \\
35 \mathrm{ppm} \\
10.000 \\
9 \mathrm{ppm}\end{array}$ & $\begin{array}{l}\text { Infravermelho não } \\
\text { dispersivo }\end{array}$ \\
\hline $\mathrm{O}_{3}$ & $1 \mathrm{~h}$ & 160 & 160 & Quimiluminescência. \\
\hline
\end{tabular}

${ }^{1}$ não pode ser excedido mais de uma vez por ano

${ }^{2}$ média geométrica anual

${ }^{3}$ média aritmética anual

Fonte: BRASIL, 1990.

A Resolução CONAMA n..$^{\circ}$ 03/90, no artigo 5. ${ }^{\circ}$, trata dos critérios para elaboração de plano de emergência, definindo como episódio crítico de poluição do ar a presença de altas concentrações de poluentes na atmosfera, em curto período de tempo, resultante de condições 
meteorológicas desfavoráveis à dispersão dos mesmos. No Quadro 3, podem ser observados os valores numéricos utilizados por essa Resolução.

Quadro 3 - Critérios para episódios agudos de poluição do ar

\begin{tabular}{|c|c|c|c|}
\hline Parâmetro & Atenção & Alerta & Emergência \\
\hline $\begin{array}{l}\text { PTS } \mu \mathrm{g} / \mathrm{m}^{3} \\
\text { Média } 24 \mathrm{~h}\end{array}$ & 375 & 625 & 875 \\
\hline $\begin{array}{c}\text { MP } 10 \mu \mathrm{g} / \mathrm{m}^{3} \\
24 \mathrm{~h}\end{array}$ & 250 & 420 & 500 \\
\hline $\begin{array}{c}\text { Fumaça } \mu \mathrm{g} / \mathrm{m}^{3} \\
24 \mathrm{~h}\end{array}$ & 250 & 420 & 500 \\
\hline $\begin{array}{c}\mathrm{SO}_{2} \mu \mathrm{g} / \mathrm{m}^{3} \\
24 \mathrm{~h}\end{array}$ & 800 & 1.600 & 2.100 \\
\hline $\begin{array}{c}\mathrm{SO}_{2} \text { X PTS } \\
\mu \mathrm{g} / \mathrm{m}^{3} \times \mu \mathrm{g} / \mathrm{m}^{3} \\
24 \mathrm{~h}\end{array}$ & 65.000 & 261.000 & 393.000 \\
\hline $\begin{array}{c}\mathrm{NO}_{2} \mu \mathrm{g} / \mathrm{m}^{3} \\
1 \mathrm{~h}\end{array}$ & 1.130 & 2.260 & 3.000 \\
\hline $\begin{array}{c}\text { CO ppm } \\
8 \mathrm{~h}\end{array}$ & 15 & 30 & 40 \\
\hline $\begin{array}{c}\mathrm{O}_{3} \mu \mathrm{g} / \mathrm{m}^{3} \\
1 \mathrm{~h}\end{array}$ & $400^{4}$ & 800 & 1.000 \\
\hline
\end{tabular}

${ }^{4} \mathrm{O}$ nível de atenção declarado pela CETESB para $\mathrm{O}_{3}$, segundo legislação estadual, é $200 \mu \mathrm{g} / \mathrm{m}^{3}$ (CETESB, 2002).

Fonte: BRASIL, 1990 


\section{b) Legislação Federal sobre Limites de Emissão de Poluentes Atmosféricos}

As diversas normas federais já publicadas estabelecem limites de emissão para fontes móveis, das quais podem ser destacadas (CETESB, 1999):

- Portaria do Ministério do Interior n. ${ }^{\circ}$ 100/80, que estabelece limites de emissão de fumaça preta para veículos a diesel;

- Resolução do Ministério da Justiça n. ${ }^{\circ}$ 507/76, que fixa limites de emissão do cárter para veículos movidos à gasolina;

- Resolução CONAMA n. ${ }^{\circ}$ 08/90, que estabelece limites máximos de emissão de poluentes no ar, para processos de combustão externa, em fontes fixas;

- Portaria IBAMA n. ${ }^{\circ}$ 1.937/90, sobre controle de emissão para veículos importados;

- Lei Federal n. ${ }^{\circ}$ 8723/93, que fixa limites de emissão para veículos a álcool;

- Resolução CONAMA n. ${ }^{\circ}$ 03/89, que fixa limites de emissão de aldeídos para veículos a álcool;

- Resolução CONAMA n. ${ }^{\circ}$ 07/89, que estabelece padrões de emissão e procedimentos para inspeção de veículos.

\section{c) Legislação Ambiental Paulista}

No Estado de São Paulo, a Lei Estadual n. ${ }^{\circ}$ 977/1976 e seu decreto regulamentador n. ${ }^{\circ}$ 8468/1976 conferem à CETESB, o controle da poluição e preservação do meio ambiente. As atividades da CETESB previstas nesta legislação compreendem a adoção de medidas preventivas e corretivas referentes à emissão e assimilação de resíduos poluidores e que coloquem em risco a qualidade das águas, do ar e do solo, em todo o Estado de São Paulo, tais como: regulamentar as ações de controle ambiental; efetuar licenciamentos para novas indústrias; aplicar sanções para ações corretivas. Essa agência é um dos cinco centros mundiais de referência considerados no programa de desenvolvimento pela Committee Ad- 
Hoc - Community Water Suply and Sanitation da Organização Mundial da Saúde (SÃO PAULO, 1976 a, b; CETESB, 2002).

A Lei n. ${ }^{\circ}$ 977/1976 e o Decreto n. ${ }^{\circ}$ 8.468/1976 mantém os padrões federais de qualidade do ar, exceto para ozônio que, na legislação paulista, apresenta um padrão mais rigoroso para o nível de atenção (SÃO PAULO, 1976 a, b).

Na região metropolitana de São Paulo, são divulgados, diariamente, pela imprensa escrita, dados sobre a qualidade do ar, disponibilizados pela CETESB, juntamente com a previsão meteorológica de dispersão dos poluentes. Para simplificar o processo de divulgação dessa informação, a CETESB utiliza o Índice de Qualidade do Ar (IQA), que foi desenvolvido pela Agência de Proteção Ambiental dos Estados Unidos (USEPA), com base em experiências obtidas naquele país e no Canadá. Os parâmetros utilizados para obtenção do IQA são: dióxido de enxofre, partículas totais em suspensão, partículas inaláveis, fumaça, monóxido de carbono, ozônio e dióxido de nitrogênio, conforme previsto na Resolução

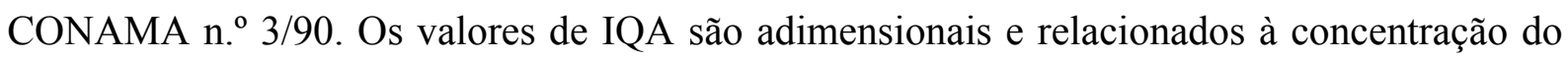
poluente, sendo divulgado o índice mais elevado, ou seja, o pior caso (CETESB, 2002).

Determinado o IQA, a qualidade do ar da área monitorada é classificada, com base na escala apresentada no Quadro 4:

Quadro 4 - Qualidade do ar em relação ao IQA

\begin{tabular}{|c|c|c|}
\hline Índice & Qualidade do Ar & Nível \\
\hline $0-50$ & BOA & \\
\hline $51-100$ & REGULAR & \\
\hline $101-199$ & INADEQUADA & ATENÇÃO \\
\hline $200-299$ & MÁ & ALERTA \\
\hline $300-399$ & PÉSSIMA & EMERGÊNCIA \\
\hline$>400$ & CRÍTICA & \\
\hline
\end{tabular}

Fonte: CETESB, 2002 
No nível de atenção, a população exposta fica sujeita ao decréscimo da resistência física e o agravamento de enfermidades cardiovasculares. No nível de alerta, estão previstos o aparecimento prematuro de certas doenças e o agravamento de sintomas, ocorrendo ainda o decréscimo da resistência física em pessoas saudáveis, sendo recomendável que a população evite atividades exteriores. Em casos de ocorrência do nível de emergência, é freqüente observar-se a morte prematura em idosos e pessoas doentes. Nestas circunstâncias, todas as pessoas devem permanecer em casa, mantendo portas e janelas fechadas, além de minimizar atividades físicas e evitar o tráfego (CETESB, 2002).

\subsection{A vegetação como bioindicador da poluição atmosférica}

A presença de agentes potenciais de poluição atmosférica nos espaços urbanos, que ameaçam a saúde e a qualidade de vida de grupos humanos e dos demais organismos vivos, assim como a integridade do meio abiótico, tem despertado a busca por medidas e estratégias destinadas à detecção precoce de processos poluidores, assim como de instrumentos e métodos de intervenção em áreas com exposição humana a poluentes.

A qualidade do ar pode ser avaliada no nível local, regional, nacional e internacional, através de estimativas das emissões, do uso de modelos matemáticos e de medidas das concentrações ambientais dos principais poluentes, utilizando-se, normalmente, métodos físico-químicos. Por estas medidas, pode-se verificar se normas e valores limites para concentrações de poluentes no ar, estabelecidos ou recomendados, estão sendo respeitados. Os resultados dessas medidas, porém, não permitem conclusões imediatas sobre os impactos das concentrações atuais de poluentes em seres vivos (KLUMPP et al., 2001).

A partir de meados do século passado, iniciou-se o processo de utilização de organismos vivos, como método auxiliar de detecção de alterações perigosas da qualidade do 
ambiente, que foi denominado de biomonitoramento (AKSOY; ÖRTÜRK, 1997; GARTY; KLOOG; COHEN, 1998; XIAO et al.; 1998).

Biomonitoramento pode ser definido como um método experimental indireto de se verificar a existência de poluentes numa certa área, utilizando-se de organismos vivos, que respondem ao estresse a que se encontram submetidos por modificações nos ciclos vitais ou pela acumulação de poluentes (CARRERAS; PIGNATA, 2001; ROSSBACH et al. 1999; WAPPELHORST et al., 2000).

Estes organismos são normalmente denominados de bioindicadores. Quando reagem ao estresse pela acumulação de substâncias nos tecidos, são reconhecidos com organismos resistentes e denominados de bioindicadores de acumulação. Quando sofrem alterações morfológicas, fisiológicas, genéticas e etológicas, são considerados organismos sensíveis e denominados de bioindicadores de reação (KLUMPP et al., 2001; NIMIS et al., 2000; SILVA et al., 2000).

Em relação aos métodos tradicionais de verificação dos níveis de poluição, o biomonitoramento apresenta vantagens como: baixo custo de instalação e acompanhamento; ausência, em geral, de aparelhagem sofisticada de medição; eficiência no monitoramento de áreas amplas e períodos longos de tempo; e, viabilidade de se avaliar elementos químicos presentes em baixas concentrações no ambiente em estudo (CARRERAS; PIGANATA, 2001; HIATT, 1999; SUMITA et al., 2003).

Alguns autores referem-se à dificuldade em se diferenciar, nos organismos, os efeitos de poluentes e processos de reação às demais condições ambientais, como solo, clima e alterações antrópicas. Assim, o biomonitoramento torna-se mais adequado quando fornece dados que podem ser comparados com informações obtidas pelos métodos convencionais de monitoramento ambiental (KLUMPP et al., 2001; NIMIS et al., 2000). 
Apesar dos efeitos observados em plantas não poderem ser extrapolados para populações humanas, os resultados de experimentos com plantas podem ser considerados para esse fim, considerando a grande sensibilidade de tais organismos, mesmo em situações de baixos níveis de contaminação do ar. Assim, é admissível considerar que, se um poluente não causa nenhum dano detectável para a maioria das espécies vegetais sensíveis, não afetará também as demais espécies, incluindo o homem (GUIMARÃES et al., 2000).

A coleta sistemática, padronizada e documentada de dados sobre os efeitos sofridos em organismos bioindicadores permite a comparação desses resultados e a implantação de um terceiro sistema de controle da qualidade ambiental, além daqueles já consagrados pelas agências de controle, que registram e analisam, com regularidade, as emissões e as concentrações de poluentes na água, no ar e no solo (KLUMPP et al. 2001).

Dentre os organismos bioindicadores, destacam-se os líquens, os musgos e as plantas superiores.

Líquens são organismos formados pela associação simbiótica permanente entre fungos e algas e/ou cianobactérias. As algas, que são sempre clorofíceas ou cianofíceas, e as cianobactérias são organismos fotobiontes, que atuam na síntese de glucídios de que carecem os componentes da associação simbiótica. Os fungos, que podem ser ficomicete, ascomicete, basideomicete ou fungo imperfeito, absorvem e armazenam a água necessária à sobrevivência do conjunto (GARTY et al., 2003; JOLY, 2002; SMITH, 1969).

Essa associação simbiótica denominada líquen forma uma estrutura sem raízes ou cutículas, dependendo principalmente da atmosfera para a obtenção de nutrientes. São capazes de viver em ampla área geográfica e de acumular elementos minerais além de suas necessidades vitais, o que os tornam excelentes indicadores da qualidade do ar (GARTY et al., 2003). 
Os musgos pertencem à Classe Musci da Divisão Bryophyta. Como os líquens, são organismos criptogâmicos, ou seja, que possuem órgãos reprodutores não evidentes, e avasculares, ocorrendo em quase todos os ecossistemas terrestres. (ADAMO et al., 2003; GARTY et al., 2003; JOLY, 2002; SMITH, 1970).

Os musgos são amplamente utilizados como bioindicadores, em virtude de características favoráveis ao biomonitoramento, como: ampla distribuição geográfica; capacidade de sobrevivência em ambientes poluídos, tendência de crescimento ao longo de todo o ano (sempre verdes); interação mais direta com o ambiente onde vive, do que as plantas superiores, em virtude da anatomia simples e ausência de cutícula; capacidade de bioacumulação (ACETO et al., 2003; ADAMO et al., 2003).

Esses organismos têm sido mais freqüentemente utilizados como acumuladores de poluentes atmosféricos, pois retiram os nutrientes principalmente do ar, pela absorção de partículas neles depositadas, provenientes do solo, de emissões marinhas e de emissões antropogênicas. Quando são epífitas, crescendo sobre troncos e galhos de árvores, podem também se utilizar dos exudados vegetais como fonte de nutrientes. Como não dispõem de sistema vascular, praticamente não ocorre o transporte de minerais entre segmentos de cada período de crescimento, o que propicia o acompanhamento histórico dos níveis de poluição ambiental (ADAMO et al., 2003; FIGUEIRA et al., 2002; GRODZIŃSKA-JURCZAC; SZAREK-ŁUKASZEWSK, 1999).

As plantas superiores (vasculares) estão compreendidas em cinco divisões: Cycadophyta, Ginkgophyta, Coniferophyta, Gnetophyta, e Angiospermae. As quatro primeiras faziam parte da divisão Gymnospermae, que foi mais recentemente subdivida, com base em análises filogenéticas e dados moleculares observados em cloroplastos de organismos daquela divisão. São também denominadas de não angiospermas com sementes, englobando as plantas 
que formam sementes nuas. À divisão Coniferophyta pertence o grupo Pinales ou das coníferas, como é vulgarmente conhecido (GODOY; PATRICIO, 2001; JUDD et al., 1999).

A divisão Angiospermae engloba o grupo de plantas que produzem sementes encerradas no ovário, formando frutos. É um dos maiores grupos de plantas, predominando atualmente na flora terrestre (JOLY, 2002).

Os vegetais, incluindo-se os musgos, e líquens têm sido largamente empregados como método complementar de monitoramento da qualidade do ar e da presença de contaminantes na troposfera (MA, 1999; PIGNATA et al., 1999; SCERBO et al., 1999).

O uso de organismos vivos permite que sejam verificados: a atividade fisiológica de substâncias nocivas, a ocorrência de intoxicações crônicas de exposições prolongadas e a pesquisa de áreas extensas e em períodos prolongados. Entretanto, acredita-se que o uso de bioindicadores e a análise direta de amostras do ar, solo e água sejam complementares, não se constituindo em alternativas concorrentes. Não se pretende a substituição dos métodos físicoquímicos de avaliação da qualidade ambiental, por métodos de biomonitoramento. Estes podem fornecer informações adicionais referentes aos efeitos de poluentes sobres os organismos vivos (FELLENBERG, 1980; KLUMPP et al., 2001).

Considerando-se que a biomassa vegetal recobre parcela significativa da superfície terrestre, os vegetais desempenham importante papel na persistência de contaminantes químicos, que são assimilados pelas plantas superiores por três vias: por translocação, a partir do solo, pela ação das raízes; por assimilação de substâncias presentes na fase gasosa; e, por assimilação de deposições atmosféricas.

Os gases poluentes são absorvidos pelas plantas através dos estômatos, por difusão gasosa. Dissolvem-se no líquido interno, penetrando nas membranas celulares de acordo com o gradiente de concentração existente. O gás é metabolizado ou decomposto no interior das células. Alguns poluentes orgânicos são absorvidos pelas plantas e não são decompostos. 
Nessa situação, poderá ocorrer um equilíbrio com as concentrações ambientais, limitando a capacidade das folhas em absorver o poluente (OMASA et al., 2000).

Já os poluentes metálicos estão associados a materiais particulados atmosféricos, que se depositam nas estruturas vegetativas de plantas, líquens e musgos, por deposição seca ou úmida. Assim como os nutrientes, esses contaminantes passam para o interior das estruturas vegetativas, inicialmente, por processo não metabólico, através de canículos existentes na cutícula das cavidades estomatais, atingindo os espaços intracelulares e paredes celulares. Posteriormente, em processo ativo e com dispêndio de energia, atravessam a membrana citoplasmática, atingindo o interior das células, por gradiente de concentração (KEANE et al., 2001; MALAVOLTA, 1985).

A categorização de plantas em grupos de sensíveis e tolerantes deve ser considerada em programas de pesquisa dessa área de conhecimento, visto que plantas sensíveis podem ser utilizadas como bioindicadores de reação e plantas tolerantes podem servir, tanto como bioindicadores de acumulação, como no abate de poluentes do ar em ambientes urbanos e industriais (PIGNATA et al., 1999).

Os bioindicadores vegetais são utilizados em ensaios de biomonitoramento basicamente em dois métodos distintos:

a) Método passivo, quando são utilizadas plantas que já habitam a área de estudo;

b) Método ativo, quando estas plantas são introduzidas de forma controlada no local a ser investigado (DOMINGOS et al., 1998; SILVA et al., 2000; SUMITA et al., 2003).

A observação de respostas visuais de plantas, musgos e líquens a ação de poluentes é uma técnica simples e pouco dispendiosa, que pode ser usada como método de verificação de toxicidade ambiental. $\mathrm{Na}$ presença de poluentes como $\mathrm{O}_{3}, \mathrm{SO}_{2}, \mathrm{NOx}$ e F, espécies podem apresentar injúrias típicas nas folhas, ou ainda, apresentarem perdas foliares, redução de 
crescimento e/ou alterações nos padrões de floração (GRODZIŃSKA-JURCZAC; SZAREKŁUKASZEWSK, 1999; KLUMPP; DOMINGOS; KLUMPP, 1996; KLUEHLER; FLAGLER, 1999; KRUPA; LEGGE, 1999; KURCZYŃSKA, et al., 1997).

Outros métodos visuais estão baseados na verificação da freqüência e abundância de espécies sensíveis expostas a poluentes atmosféricos (SCERBO et al., 1999).

Mais recentemente, a determinação de: composição química, alterações nos processos fisiológicos e alterações genéticas em plantas têm sido utilizadas como base para a determinação de impactos de longa duração, por demonstrarem antecipadamente, em relação aos sintomas visuais, que as condições atmosféricas apresentam qualidade modificada (PIGNATA et al., 1999; RIBAS; PEÑUELAS, 2003; RODRIGUES et al. 1997; SUYAMA et al., 2002).

Diversas instituições de pesquisa têm dedicado esforços na avaliação dos efeitos da poluição atmosférica sobre sistemas vegetais terrestres, destinados à exploração florestal, ou em ecossistemas naturais localizados junto a áreas de concentração industrial.

A Associação Florestal Americana (AFA, 1987) avaliou a ação da poluição do ar em florestas e ecossistemas florestais, provocando principalmente a denominada "chuva ácida", que se forma em regiões onde a concentração de óxidos de enxofre no ar é elevada, por emissões industriais, através da queima de combustíveis fósseis.

Backiel e Hunt (1986) verificaram variação de crescimento, presença de lesões foliares e mortalidade de indivíduos de diversas espécies de pinheiros, na presença de $\mathrm{O}_{3}$ e outros oxidantes fotoquímicos, em localidades montanhosas da Califórnia, USA.

Rinne e Makienen (1988) avaliaram as variações de concentração de $\mathrm{Cu}, \mathrm{Fe}, \mathrm{Pb}, \mathrm{Zn}$, $\mathrm{Ca}, \mathrm{Mg}$ em duas espécies diferentes de musgos, em florestas de coníferas no norte e no sul da Finlândia e no norte da Noruega, localizadas próximas a fontes de emissão atmosférica 
industrial, verificando decréscimo significativo nas concentrações de $\mathrm{Fe}$ e $\mathrm{Zn}$ nas duas espécies de fungos, com o aumento da distância das fontes de emissão.

Kaufman (1989) verificou que, em uma propriedade rural localizada em uma tranqüila montanha em Vermont, a poucas milhas do sul do Canadá, diversos indivíduos florestais haviam morrido nos últimos cinco anos, sendo o problema relacionado com a ação de chuva ácida e outros agentes da poluição do ar.

No Canadá, o South Riverdale Community Health Centre (1995) relatou que os jardins das residências podiam demonstrar a ocorrência de contaminação ambiental por $\mathrm{Pb}$, quando próximos de rodovias, de incineradores ou de outras fontes específicas de contaminação, pela ocorrência de crescimento atípico nas plantas ou pela presença de injúrias.

Na região Sul do Brasil, nas proximidades da Usina Termoelétrica Presidente Medici, também conhecida como CANDIOTA II, foram observadas deposições de cinzas nas pastagens próximas, contendo concentrações de fluoretos acima do suportado pela atividade pecuária, provocando lesões dentárias em bovinos e ovinos (ESTRADA, 1990).

Mendonça e Silva (1991) avaliaram a influência da poluição atmosférica em espécies de hortaliças, que apresentaram redução de crescimento, lesões, necroses e cloroses, em áreas de teste próximas à fonte emissora, uma indústria têxtil, em Teresópolis, Rio de Janeiro.

Klumpp et al. (1994) expuseram plantas bioindicadoras à ação de poluentes atmosféricos presentes em emissões do Complexo Industrial de Cubatão, Brasil, verificando a ocorrência de fitotoxidade por oxidantes fotoquímicos em uma extensa área da reserva florestal da Serra do Mar. O estudo demonstrou viabilidade no uso de bioindicadores, com base em metodologia tradicionalmente aplicada em regiões de clima temperado, nas regiões de clima tropical e subtropical.

Em Porto Alegre, região sul do Brasil, Kammerbauer e Dick (2000) utilizaram plantas da espécie Ricinus communis expostas a emissões de escapamentos de veículos, em vias 
públicas urbanas. Embora não tenham sido observadas injúrias, verificaram-se diferenças significativas na taxa de crescimento, em atividades enzimáticas, na concentração de clorofila, dentre outras, entre plantas expostas e plantas-controle.

Cole et al. (1999), na busca de indicadores eficazes da qualidade do ar, para uma comunidade canadense, avaliaram que os indicadores atualmente em uso não refletem o impacto sobre a saúde humana, sugerindo que um indicador deva ser facilmente compreendido pela comunidade, assim como estar ligado às condições locais, possibilitando a identificação de solução para o problema revelado.

Em pesquisa realizada por esses mesmos autores, os participantes percebiam as condições de poluição atmosférica utilizando-se dos cinco sentidos, sendo os sinais visuais os mais freqüentemente citados, tais como: condições do céu, sujeiras nas janelas e nas piscinas, deposições nas folhas das plantas, folhas secas e mortas. Alguns participantes mencionaram que um indicador pode representar um importante papel na observação de melhorias ou declínios na qualidade do ar local, motivando as pessoas a alterarem seus hábitos e comportamentos, pela visualização da correlação existente entre saúde humana, sustentabilidade e ecossistema.

Klumpp et al.(2001) afirmam que plantas bioindicadoras têm exercido papel cada vez maior no controle da qualidade do ar, tendo em vista que os efeitos negativos da poluição sobre eles são facilmente verificáveis, inclusive para leigos.

Assim, buscamos aqui evidenciar como bioindicadores vegetais podem auxiliar no processo de percepção de riscos à saúde e ao ambiente, pelos órgãos responsáveis pelo monitoramento de saúde ambiental, bem como pelas populações afetadas. Uma vez advertida sobre os riscos a que se encontra submetida, a população poderá interferir positivamente nas decisões político-administrativas que determinarão a sua realidade futura de saúde e bemestar. 


\subsection{Avaliação, percepção e comunicação de risco ambiental}

Para Braga et al. (2002), os efeitos globais da poluição ambiental têm contribuído para uma maior sensibilização da sociedade sobre a importância das questões ambientais, o que vem tendo, também, um destaque na mídia, bem como na agenda de políticos e de grupos ambientalistas de todo o planeta.

Neste contexto, Chapman (2001) discute a representação que determinadas palavras ligadas às questões ambientais têm para diferentes grupos sociais, principalmente entre cientistas e leigos.

O autor faz distinção entre contaminantes e poluentes, classificando os primeiros como substâncias que são encontradas onde não deveriam estar ou em níveis acima daqueles que ocorrem em condições normais. Considera poluição como uma contaminação que resulta em efeitos biológicos adversos ao ambiente. Portanto, para este autor "um poluente é sempre um contaminante, mas nem todo contaminante é um poluente", sendo necessário, para que a toxicidade se manifeste, que um receptor biológico esteja em contato com o potencial tóxico e que este se encontre em dose e espécie química apropriada, para provocar danos à saúde do receptor (CHAPMAN, 2001, p. 1279).

No Brasil, os termos "poluição" e "poluente" são relacionados a situações de elevado potencial tóxico, pelos órgãos gerenciadores ambientais, pela mídia e pela própria população.

A avaliação de risco como um processo analítico aplicado a questões ambientais, desenvolvido para assessorar agentes reguladores na tomada de decisões políticoadministrativas, tem uso relativamente recente, estabelecendo-se a partir de meados do século passado. Teve origem na área de toxicologia médica, principalmente em avaliações de riscos à exposição ocupacional por agentes químicos (EDULJEE, 2000). 
Botkin e Keller (2000) definem avaliação de risco como o processo de determinação dos efeitos de condições ambientais potencialmente adversas sobre a saúde de pessoas continuamente expostas a poluentes ou outros materiais tóxicos.

De acordo com estes autores e com James e Campbell (1994), a avaliação de riscos ambientais ocorre em quatro etapas:

a) identificação do perigo, quando se verifica se um determinado agente causa efeitos adversos à saúde, utilizando-se grupos humanos previamente expostos, métodos experimentais em animais, ou ainda, a ação de certos materiais no nível molecular;

b) avaliação da dose-resposta, identificando-se a relação entre a dose de um poluente ou toxina e a natureza/extensão de um efeito adverso sobre a saúde de uma determinada população;

c) avaliação da exposição, estimando-se a intensidade, duração e freqüência da exposição humana a uma toxina ou poluente; e,

d) caracterização do risco, verificando-se a magnitude do efeito adverso em uma dada população, resultante da exposição a um determinado poluente ou toxina.

O gerenciamento de um risco reconhecido implica na tomada de medidas que visem eliminá-lo ou reduzí-lo a um nível aceitável pelas agências ambientais, visando reduzir perdas de vida, doenças, injúrias e danos a propriedades e ao meio ambiente (MILLAR, 1992; NSC, 1991).

No gerenciamento de riscos, uma das etapas necessárias recai sobre a verificação da percepção de riscos pela população. O grau de percepção de risco, normalmente, reflete as concepções que uma dada comunidade tem sobre risco, saúde e conseqüências para o meio ambiente, as quais estão baseadas em valores subjetivos e em julgamentos intuitivos. Entretanto, para a maioria do público, as experiências com riscos à saúde e ao ambiente ocorrem a partir de notícias veiculadas pela mídia, que atua como um dos importantes meios 
de comunicação de riscos à sociedade, havendo uma ação irrelevante por parte de órgãos públicos (BRILHANTE; CALDAS, 1999; CARNEIRO, et al., 2003; CROSS, 1998; SLOVIC, 2000).

A comunicação de risco pode ser definida como a troca de informações sobre a natureza, magnitude, significância ou controle de um determinado risco, entre as partes interessadas, ou seja, agências governamentais, indústrias, mídia, academia científica, organizações profissionais, grupos de interesse e a comunidade em geral, podendo ocorrer previamente ou durante situações de risco (COVELLO, 1991; LEISS, 1995).

Covello (1991) avalia que, no processo de comunicação de riscos, são verificadas certas dificuldades, como: limitações de dados científicos, das informações fornecidas pelos geradores e fiscalizadores, bem como do público, em interpretar as informações disponíveis sobre o risco. Destaca as recomendações da Agência de Proteção Ambiental Americana USEPA para minimizar essas dificuldades, que são:

a) envolver o público e aceitá-lo como parceiro legítimo;

b) planejar cuidadosamente as medidas de proteção ambiental em uso e avaliar sua performance;

c) considerar a audiência;

d) ser honesto, franco e aberto;

e) colaborar com outras fontes de comunicação;

f) suprir as necessidades da mídia; e,

g) fazer a comunicação de forma calma e pausada, facilitando o seu entendimento.

Em pesquisa realizada no Canadá, para avaliar a percepção de risco à saúde pela população, foi observado que $62,9 \%$ dos entrevistados que fizeram associação negativa com a palavra "químicos", também consideravam a poluição química como de alto risco. Nessa pesquisa, também foram considerados altos o risco decorrente da redução da camada de 
ozônio e o risco associado à exposição ao sol. O ozônio troposférico, produzido por processos industriais e na queima de combustível fóssil, que envolvem altas temperaturas, também foi considerado alto, assim como a exposição a Biefenilapolicloradas - PCBs ou dioxinas. As mudanças climáticas globais foram consideradas de risco moderado. Houve, além disso, uma forte tendência em associar riscos à saúde com poluição industrial e um entendimento quase unânime $(93,4 \%)$ de que a terra, o ar e a água estão mais contaminados agora do que em tempos anteriores (CANADA, 1993).

Elliot et al. (1999) investigando a percepção de risco existente entre residentes nas proximidades de zona industrial de Hamilton, Ontario, Canadá, em função da qualidade adversa do ar, encontraram resultados que legitimam os anseios e preocupações da comunidade sobre o efeito da qualidade do ar na saúde, propondo que essa temática deva ser incluída na agenda da política local urbana.

Jacobi (1997) relata pesquisa realizada em 1000 domicílios pertencentes a 30 bairros da cidade de São Paulo, em que investigou a percepção desses entrevistados sobre os problemas ambientais e sua relação com a qualidade de vida das pessoas diretamente atingidas. Dentre as alternativas apresentadas, a questão da poluição do ar obteve maior repercussão, representando $13,3 \%$ dos domicílios, dos quais $70 \%$ das falas relacionavam-se aos efeitos sobre a saúde, propondo que essa temática fosse incluída na agenda da política local urbana.

\subsubsection{O Distrito Industrial de Ribeirão Preto (DIRP) como fonte potencial de}

\section{poluição ambiental}

Em Ribeirão Preto, cidade situada na região Nordeste do Estado de São Paulo, com população superior a 500 mil habitantes, o DIRP (Lei n. ${ }^{\circ}$ 3928/81, substituída pela Lei n. ${ }^{\circ}$ 8681/2000) encontrava-se em processo de licenciamento ambiental, na época da realização do 
presente trabalho, visando a instalação e operação de atividades de natureza principalmente industrial, não havendo registro da existência de estudos controlados sobre a percepção da comunidade local a respeito desse empreendimento (CODERP, 2003; RIBEIRÃO PRETO, 2000).

Ainda que localizado em área de expansão urbana, especificamente no entroncamento do Anel Viário Contorno Norte (Rodovia Alexandre Balbo) e Rodovia Anhanguera, conforme indicado na Figura 1, o DIRP situa-se a menos de 1000 metros de conjuntos habitacionais ocupados por população de baixa renda, que estará, gradativamente, mais exposta à ação de contaminantes ambientais gerados nos processos industriais que ali deverão estar concentrados, nos próximos anos.

A perspectiva da existência de futuros focos de contaminação do ar no município de Ribeirão Preto leva-nos à busca da construção de conhecimento sobre o uso de vegetação, cujas alterações por agentes poluidores sejam facilmente observáveis, servindo-se como indicadores da qualidade do ar. Consideramos que o uso de bioindicadores vegetais poderá servir ao processo de avaliação, percepção e comunicação de riscos ambientais decorrentes da ação de poluentes atmosféricos na área de influência do DIRP e demais setores do município submetidos ao constante contato com estes agentes de poluição ambiental.

Visando contribuir para a utilização do biomonitoramento em processos de poluição ambiental urbana, propusemos-nos a efetuar uma busca bibliográfica sistematizada sobre bioindicadores vegetais de poluição atmosférica e sua aplicabilidade em territórios subtropicais. 


\section{OBJETIVOS}

\subsection{Objetivo geral}

Contribuir para o conhecimento na área de poluição ambiental, em especial na busca de novas alternativas para a detecção de processos de poluição atmosférica decorrentes da ação humana.

\subsection{Objetivos específicos}

I. Levantar, na literatura acadêmica do período compreendido entre janeiro de 1997 e junho de 2003, as diferentes espécies vegetais, incluindo-se musgos, e líquens, utilizados como bioindicadores de poluição atmosférica, bem como as diferentes formas de utilização experimental dessas espécies e suas relações com os poluentes atmosféricos selecionados;

II. Identificar, dentre as espécies vegetais encontradas, aquelas utilizadas com maior freqüência, em escala experimental, nos diferentes centros de pesquisa do Brasil e do mundo;

III. Identificar, dentre as espécies vegetais utilizadas como bioindicadores de poluição atmosférica, aquelas com ocorrência natural em território brasileiro, bem como espécies exóticas cultivadas, cujo uso em sistemas de biomonitoramento possa ser avaliado em áreas urbanas e industriais, inclusive no município de Ribeirão Preto, região Sudeste do Brasil. 


\section{METODOLOGIA}

Trata-se esta de uma pesquisa descritiva, baseada em revisão sistemática da literatura, visando reunir o conhecimento pouco estudado e divulgado na literatura acadêmica nacional, referente ao uso de bioindicadores vegetais, como método complementar de monitoramento da contaminação atmosférica.

A investigação restringiu-se aos estudos que avaliaram a ação dos contaminantes mais freqüentemente monitorados pelas agências de controle ambiental, sobre líquens, musgos e vegetais superiores (vasculares), a saber: partículas em suspensão (PTS), material particulado (MP-10), metais pesados, dióxido de enxofre $\left(\mathrm{SO}_{2}\right)$, óxidos de nitrogênio $\left(\mathrm{NO}_{\mathrm{x}}\right)$, ozônio $\left(\mathrm{O}_{3}\right)$, monóxido de carbono (CO), compostos orgânicos voláteis (VOCs), hidrocarbonetos, gás fluorídrico (HF) e demais fluoretos gasosos.

Corroborando com idéias de Minayo (1994), que destaca os problemas da vida prática como desencadeadores de processos intelectuais, consideramos que este levantamento traz importante colaboração para o processo de tomada de decisões em políticas públicas na área de poluição ambiental, como mais um instrumento para o conhecimento e controle de poluição atmosférica, aplicável à realidade local, regional e nacional. Sabendo-se que problemas ambientais não se limitam a espaços restritos, mas apresentam importância global, lembramos o slogan da Organização Mundial da Saúde na década de 90 do séc. XX: "Pense globalmente e aja localmente” (WHO, 1990, p.1). 


\subsection{Revisão sistemática da literatura}

Para o alcance dos objetivos pretendidos, tomamos por base a metodologia da revisão sistemática da literatura, buscando a integração da informação acadêmica produzida em diferentes situações, locais e grupos de pesquisa, possibilitando a produção da evidência científica pretendida (GREENHALGH, 1997; MUÑOZ et al., 2002).

A Revisão Sistemática tem caráter qualitativo, tendo em vista que os resultados obtidos não são submetidos à análise estatística. De acordo com Greenhald (1997) e Muñoz et al. (2002), após a definição do problema, os pesquisadores devem percorrer os passos indicados na figura 2, apresentada a seguir, sendo recomendável que a revisão seja realizada por, no mínimo, dois pesquisadores, de forma independente, visando-se garantir a objetividade do método.

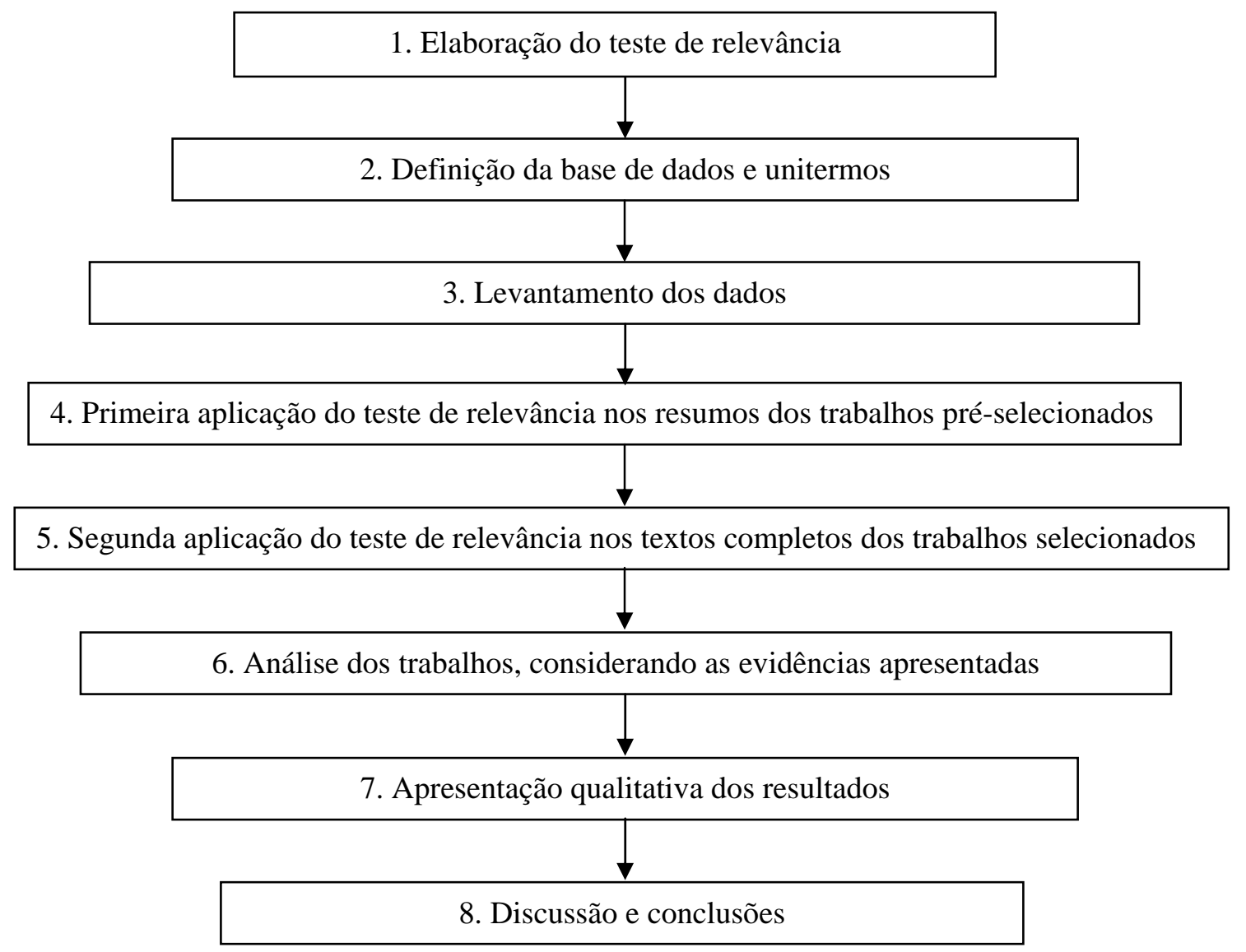

Figura 2 - Esquema dos passos percorridos em Revisão Sistemática da Literatura 


\subsection{Percurso metodológico}

Adaptando-se a metodologia acima descrita à presente investigação, foram percorridas as etapas descritas nos itens a seguir.

\subsection{1 - Elaboração dos instrumentos de coleta de dados}

Os instrumentos de coleta de dados constituíram-se de dois formulários denominados Teste de Relevância 1 (TR1) e Teste de Relevância 2 (TR2), elaborados para avaliar a inclusão ou não dos artigos levantados junto às bases de dados selecionadas.

O TR1 (Apêndice A) foi desenhado para atender à primeira fase de seleção de artigos científicos, com base na leitura dos resumos, enfocando as seguintes informações, que constituíram, também, os critérios de inclusão dos artigos encontrados, nessa primeira aplicação dos testes de relevância:

- Período de publicação: foram aceitos os trabalhos publicados de janeiro de 1997 a junho de 2003, buscando-se a obtenção de dados mais recentes, em período de tempo que pudesse expressar o desenvolvimento científico sobre o assunto, considerando-se, ainda, a disponibilização de dados no meio eletrônico;

- Tipo de publicação: foram aceitos apenas estudos experimentais e/ou descritivos observacionais;

- Idioma: foram aceitos artigos nas línguas inglesa, espanhola ou portuguesa;

- Assunto: foram incluídos estudos que abordavam espécies vegetais vasculares, musgos e líquens relacionados à poluição do ar.

O TR2 (Apêndice B) foi desenhado de modo possibilitar a inclusão ou exclusão definitivas dos artigos na íntegra a que se teve acesso, tendo sido considerados como fatores de inclusão: 
- Estudos que consideraram, direta ou indiretamente, qualquer um dos poluentes selecionados na presente pesquisa (PTS, MP-10, metais pesados, $\mathrm{SO}_{2}, \mathrm{NO}_{\mathrm{x}}, \mathrm{O}_{3}$, CO, VOCs, hidrocarbonetos, HF e demais fluoretos gasosos);

- Presença de danos verificáveis a olho nu em folhas, caule, flores ou frutos, dos vegetais analisados, bem como modificações anatômicas, metabólicas, fisiológicas e genéticas, não visíveis a olho nu;

- Correlação entre as alterações verificadas nos vegetais, com concentrações de poluentes atmosféricos;

- Estudo sobre o uso de vegetais como bioindicadores ou bioacumuladores.

\subsubsection{Fonte de dados}

Antes de procedermos à pesquisa bibliográfica, foi efetuada a seleção de palavraschave e descritores de assunto que enfocassem bioindicadores vegetais de poluição atmosférica, tendo sido utilizadas diferentes palavras e descritores, de acordo com o banco ou base de dados consultados.

As bases de dados utilizadas foram: Biological Abstracts, da Eletronic Reference Library (ERL), MedLine, Agris e, também, os bancos e bases de dados nacionais e latinoamericanos Lilacs, Instituto Brasileiro de Informações em Ciências Tecnológicas (IBCT) e Dedalus, no período de janeiro de 1997 a junho de 2003.

Assim, na pesquisa bibliográfica efetuada em bases de dados eletrônicas, foram utilizadas duas vias para pesquisas dessa natureza:

a) busca em grupos de assuntos, utilizando-se descritores ou unitermos disponibilizados pela base de dados em uso, ou;

b) busca por meio de palavras-chave, em qualquer lugar do texto ou título. 
Tendo sido verificado que cada base disponibilizava seus dados em diferentes períodos, procurou-se adequar as buscas ao período selecionado, ou seja, de janeiro de 1997 a junho de 2003. Os artigos científicos pré-selecionados que se situavam fora do período deste estudo foram excluídos.

A seguir, descreveremos bases e bancos de dados utilizadas em nossa pesquisa:

\section{Biological Abstract}

Foi acessada através da Eletronic Reference Library - ERL, no grupo das Ciências Biomédicas e Agrárias, que disponibiliza registros a partir do ano de 1998.

Iniciando-se as buscas por meio de unitermos, não se obteve resultados; assim, adotou-se, para o idioma inglês, a palavra-chave "bioindicator", buscada em qualquer parte do texto ou título. Delimitou-se a pesquisa em artigos científicos, ficando o período restrito entre janeiro de 1998 e junho de 2003.

$\mathrm{Na}$ busca de trabalhos científicos publicados no idioma inglês, também foram utilizadas palavras-chave compostas com os elementos da pesquisa, ou seja, "plant bioindicator” e “vegetable bioindicator”.

Na mesma base de dados, também buscaram-se os artigos científicos publicados no idioma espanhol, no período de janeiro de 1998 a junho de 2003, utilizando-se a palavrachave "bioindicador”, além da busca por grupos de assuntos previamente sistematizados e disponibilizados pela base de dados em questão: “plant accumulation”, “air pollution tolerance index" e "pollution assessment control and management”, o que possibilitou o acesso a trabalhos publicados no idioma espanhol sobre bioindicadores vegetais de poluição atmosférica. 


\section{MedLine}

Trata-se de base de dados prioritariamente da área da saúde, disponível ao público, a partir da base PubMed, produzido pela National Library of Medicine. Esta base de dados possibilita o acesso a citações a partir de 1950. Devido à forma de lançamento dos dados pela referida base, houve, aqui, a necessidade de se delimitar a pesquisa a partir do ano de 1996, tendo sido excluídos os artigos com publicação anterior a janeiro de 1997. A busca foi efetuada por meio da palavra-chave "bioindicator”.

\section{Agris}

A base de dados Agris foi acessada a partir da Eletronic Reference Library - ERL. Trata-se de base de dados de artigos científicos da área agronômica. A busca foi limitada a trabalhos científicos publicados nos idiomas inglês e espanhol, no período de janeiro de 1995 a junho de 2003, por restrições impostas pela base, a partir das palavras-chave "bioindicator" e "bioindicador", incluídos apenas os estudos publicados no período selecionado para esta investigação.

\section{Lilacs}

Nesta base de dados, também foram utilizadas palavras-chave referentes ao tema da pesquisa: “bioindicador” e o seu derivado no idioma inglês, “bioindicator”.

Procedeu-se também a busca por meio de descritores de assunto: "poluição atmosférica”, “indicadores de contaminação”, “poluição atmosférica-indicadores de contaminação”, “poluição atmosférica-indicadores biológicos”, “indicadores de contaminação-contaminação do ar”, selecionando-se o período de interesse para esta pesquisa. 


\section{Dedalus}

Trata-se do banco de dados bibliográficos da Universidade de São Paulo, tendo sido utilizado o catálogo on-line global, que abrange todas as bibliotecas da Universidade de São Paulo. Procedeu-se, inicialmente, a busca por trabalhos científicos, utilizando-se a palavra "bioindicador”. Em seguida, procedeu-se à busca por assunto, utilizando-se os seguintes descritores: "poluição atmosférica-efeitos adversos”, “poluição atmosférica-avaliação", “poluição atmosférica-prevenção e controle”, “poluição atmosférica-meteorologia”, para trabalhos publicados no período de nosso interesse.

\section{Instituto Brasileiro de Informações em Ciência e Tecnologia - IBICT}

A busca foi efetuada na Biblioteca Digital de Teses e Dissertações, utilizando-se palavras-chave que fizessem referência ao tema da pesquisa: "bioindicador”, "poluição atmosférica” e "bioacumulação”, selecionando-se o período de interesse para esta pesquisa.

\section{Pesquisa informal em acervos particulares}

Considerando-se a possibilidade de que os sistemas de busca indexados às vezes não cobrem determinados tipos de produção bibliográfica, efetuou-se, também, uma busca nos acervos particulares de alguns centros de pesquisa, como: Laboratório de Poluição Atmosférica Experimental (LPAE) da Faculdade de Medicina da Universidade de São Paulo; Departamento de Biologia da Faculdade de Filosofia, Ciências e Letras de Ribeirão Preto da Universidade de São Paulo e Laboratório de Saúde Ambiental da Escola de Enfermagem de Ribeirão Preto da Universidade de São Paulo. Também o acervo particular da pesquisadora foi utilizado. 


\subsubsection{Coleta de dados}

A seleção dos trabalhos científicos deu-se em três etapas: leitura prévia seletiva, aplicação do TR1 e aplicação do TR2. A análise da bibliografia levantada foi realizada por dois pesquisadores, de forma independente, que se reuniram para a compilação dos dados, após a aplicação do TR1 e TR2.

Na leitura prévia seletiva, os resumos foram analisados, por um revisor, de modo a incluir-se apenas os artigos que tratavam da relação direta entre poluição do ar e bioindicadores vegetais, tendo em vista a amplitude de dados obtidos pelas palavras-chave e descritores de assunto utilizados.

Pela aplicação do TR1, foram excluídos os artigos dos tipos revisão bibliográfica, relato ou editoral e as publicações fora do período admitido. Também artigos publicados na íntegra em outros idiomas foram excluídos, assim como estudos relacionados a outros tipos de bioindicadores não vegetais e ao biomonitoramento exclusivo de solo ou água. Artigos repetidos, ou seja, aqueles levantados em mais de uma base de dados, e artigos que não tivemos acesso por via on-line ou por comutação bibliográfica foram, também, excluídos nessa fase da seleção.

A aplicação do TR1 admitiu três possibilidades de classificação de cada artigo cientifico, sendo: inclusão, exclusão ou dúvida. O resumo em dúvida foi relido em conjunto pelos dois revisores, discutindo-se sua classificação final na categoria incluído ou excluído. Foram incluídos os resumos que obtiveram resposta afirmativa para todas as perguntas formuladas pelo TR1. Uma vez selecionados os resumos, buscamos pelos estudos na íntegra, nas seguintes fontes:

- Revistas eletrônicas disponíveis pelo Sistema Integrado de Bibliotecas (SIBiNET), cujo acesso é permitido a partir de equipamentos existentes nos campi da Universidade de São Paulo, pelo endereço eletrônico <http://www.sibi.usp.br>; 
- Revistas eletrônicas disponíveis no portal da CAPES, cujo acesso é livre e gratuito de terminais de instituições participantes, pelo endereço eletrônico $<$ http://www.periodicos.capes.gov.br>;

- Biblioteca da Faculdade de Saúde Pública da Universidade de São Paulo;

- Biblioteca Central do Campus Administrativo de Ribeirão Preto;

- Acervos particulares de alguns pesquisadores das áreas de saúde ambiental e biologia vegetal.

Tendo-se obtido os artigos e estudos na íntegra, procedeu-se à aplicação do TR2, que admitia duas possibilidade: inclusão ou exclusão do trabalho científico. No caso de dúvida, foi realizado o mesmo procedimento para o TR1, não tendo permanecido discordância posterior à análise conjunta realizada pelos dois revisores.

A exclusão definitiva de um artigo científico deu-se pela resposta negativa à primeira pergunta do TR2 ou a todas elas.

\subsubsection{Compilação e análise dos dados}

Tendo em vista a diversidade de informações colhidas na leitura dos estudos científicos completos, buscou-se uma forma adequada de sistematização dos dados, visando possibilitar a identificação rápida de tópicos essenciais sobre o uso de bioindicadores vegetais de poluição atmosférica, revelados pelos diferentes autores. Estas informações compiladas encontram-se apresentadas no Quadro 7, páginas 56 a 68, tomando-se por base os seguintes tópicos:

a. Referência bibliográfica: autoria e data de publicação;

b. Local do estudo: cidade ou região e país;

c. Vegetal empregado: nome específico ou gênero, divisão e ordem botânica, hábitos da planta; 
d. Poluentes e fontes de poluição analisados;

e. Tipo de exposição da planta aos poluentes: ativa ou passiva, no campo ou no laboratório;

f. Tempo de exposição da planta aos poluentes;

g. Parâmetros analisados pelos pesquisadores, após exposição da planta às condições ambientais investigadas;

h. Tipo de bioindicador vegetal: de reação ou acumulação.

Os bioindicadores pertencentes ao grupo dos vegetais vasculares, isto é, que não fossem musgos ou líquens, tiveram, ainda, acrescidas as seguintes informações complementares, constantes nos Quadros 8, 9, 10, 11, nas páginas 70 a 76:

- Identificação das famílias botânicas, baseados no referencial teórico específico da área, a saber: Graf (1978), Graf (1985), Lorenzi (1992), Lorenzi e Souza (1995), Lorenzi (1998), Lorenzi et al. (2003), bem como nos portais eletrônicos da Base de Dados Tropical (www.bdt.fat.org.br), do Missouri Botanical Gardens (http://mobot.mobot.org) e da International Plant Names Index, IPNI (www.ipni.org);

- Distribuição geográfica natural e registros de coleta;

- Verificação de cultivo e adaptação das espécies nas regiões brasileiras.

Para a verificação das áreas de ocorrência natural, dos registros de coleta e cultivos nas regiões brasileiras, foram utilizadas as mesmas fontes empregadas para a busca de famílias científicas.

Por se tratar de investigação que não abrange questões éticas, ligadas diretamente com seres humanos, esta investigação não foi submetida à apreciação de experts de comitê de ética. 


\section{RESULTADOS E DISCUSSÃO}

Esta investigação gerou resultados de duas naturezas: primeiramente, destaca-se a apresentação de nossa vivência com a revisão sistemática da literatura aplicada à área de bioindicadores vegetais associados a processos de poluição do ar. Também ressaltam-se os dados obtidos quanto à especificidade do uso de bioindicadores vegetais relacionados à poluição atmosférica.

\subsection{Quanto à Revisão Sistemática da Literatura}

Seguindo-se os passos metodológicos previstos para estudos baseados em revisão sistemática da literatura, constatamos aspectos diferenciais no trabalho, desde a aplicação de unitermos e palavras-chave, até a efetiva obtenção da bibliografia sobre o tema selecionado para nossa pesquisa.

O levantamento bibliográfico efetuado conduziu-nos, inicialmente, a um universo de 4547 estudos científicos, dos quais nem todos se referiam ao tema pesquisado, visto abrangerem as diversas formas de bioindicadores vegetais, animais e do metabolismo humano, utilizados para avaliação de contaminação do ar, da água, do solo, ou ainda relativos à saúde humana. Essa seleção foi realizada por meio de uma leitura seletiva, à medida em que foram feitas as buscas nos bancos e bases de dados. Na leitura seletiva, também foi observada 
a data de publicação dos estudos, de modo a selecionarmos apenas os trabalhos publicados no período considerado para esta investigação.

Desse grupo inicial de estudos levantados, após a leitura prévia seletiva, foram selecionados 279 trabalhos referentes a bioindicadores vegetais de poluição atmosférica, incluindo, além de artigos científicos, uma dissertação de mestrado e uma tese de doutorado. O restante (4268) foi excluído desta investigação.

As buscas nos diferentes bancos e bases de dados utilizados resultaram em dados diferenciados, segundo as palavras-chave ou descritores utilizados nos sistemas de busca.

\subsubsection{Levantamento nos Bancos e Bases de Dados}

\section{Biological Abstract}

Adotando-se, para o idioma inglês, a palavra-chave "bioindicator”, a ser buscada em qualquer parte do texto ou título, de artigos publicados de janeiro de 1998 a junho de 2003, no Biological Abstract, foi possível o acesso a 3695 artigos científicos. Desse total, foi aplicado o TR1 em apenas 222 resumos de artigos científicos. Os resumos restantes não se relacionavam a bioindicadores vegetais e processos de poluição do ar.

As palavras-chave compostas utilizadas: “plant bioindicator" e "vegetable bioindicator” levaram a um resultado nulo de artigos científicos disponíveis.

O mesmo ocorreu com a busca por artigos científicos publicados no idioma espanhol para o mesmo período, utilizando-se a palavra-chave "bioindicador" e os descritores "plant accumulation" e "air pollution tolerance index". Para o descritor "pollution assessment control and management”, foram encontrados 92 resumos. Com a leitura seletiva, verificouse a ocorrência de 1 repetição, sendo os demais resumos de artigos excluídos, por não se referirem ao tema pesquisado. No idioma espanhol, 4 artigos científicos publicados e disponíveis nesta base de dados foram encaminhados para aplicação TR1. 


\section{MedLine}

Na busca pela base Medline, o uso da palavra-chave “bioindicator” permitiu identificar 166 resumos de artigos científicos publicados no idioma inglês, no período de janeiro de 1997 a junho de 2003. Desse total, foram selecionados 20 resumos que abordavam o uso de bioindicadores vegetais para poluentes atmosféricos. Dentre esses, 14 foram excluídos por serem repetições de artigos selecionados anteriormente, em outra base de dados. Resultaram em 6 resumos de artigos científicos para a aplicação do TR1.

\section{Agris}

Pela base de dados Agris, foram encontradas 69 referências bibliográficas publicadas no idioma inglês, no período de janeiro de 1997 a junho de 2003, com o uso da palavra-chave "bioindicator”. Desse total, pela leitura prévia seletiva, 63 estudos não se referiam ao tema pesquisado, 1 foi excluído por repetição e 5 foram selecionados para aplicação do TR1. Nenhuma referência foi obtida pelo uso da palavra-chave "bioindicador”.

\section{Lilacs}

Com a palavra-chave "bioindicador”, utilizando-se a base de dados Lilacs, foram encontrados 3 resumos de artigos científicos publicados no idioma espanhol, os quais não puderam ser selecionados por não se referirem a bioindicador vegetal de poluição atmosférica.

Com o termo correspondente no idioma inglês, "bioindicator”, foram encontradas 6 referências, que também não puderam ser selecionadas pelo motivo anteriormente exposto.

Com o uso dos descritores compostos: "poluição atmosférica-indicadores de contaminação”, “poluição atmosférica-indicadores biológicos” e “indicadores de contaminação-contaminação do ar”, não foi encontrada nenhuma indicação de trabalho científico sobre o tema pesquisado. 
Utilizando-se o descritor “indicadores de contaminação" isoladamente, foram encontrados 28 referências, das quais nenhuma foi selecionada pois não se referiam ao tema de nossa pesquisa.

O descritor “poluição atmosférica”, quando utilizado isoladamente, permitiu o acesso a 258 resumos, dos quais foram selecionados apenas 4 e o restante excluído pelo motivo já apresentado. Dos 4 resumos selecionados, 3 foram excluídos por repetição, restando apenas 1 resumo de artigo científico para a aplicação do TR1.

\section{Dedalus}

Com o uso da palavra-chave "bioindicador", no banco de dados Dedalus, foram encontrados 11 estudos, sendo selecionado apenas 1 deles.

Foram encontradas 7 referências para o assunto "poluição atmosférica-efeitos adversos”, dos quais não se selecionou nenhuma pela leitura seletiva.

Com o uso do descritor de assunto "poluição atmosférica-avaliação”, foram encontradas 2 referências bibliográficas, que também não foram selecionadas, por não se referirem ao tema da nossa pesquisa.

Para o descritor de assunto “poluição atmosférica-prevenção e controle”, foram encontradas 3 referências, que também não faziam parte do tema da pesquisa.

Com o descritor de assunto “poluição atmosférica-meteorologia” foram selecionadas 3 referências, das 117 encontradas.

Pela impossibilidade de acesso aos resumos de 3 das referências selecionadas, apenas o resumo de um artigo científico do banco de dados Dedalus foi encaminhado para a aplicação do TR1. 


\section{Instituto Brasileiro de Informações em Ciências e Tecnologia - IBICT}

A busca com a palavra-chave "bioindicador" levou-nos a 2 referências de estudos sobre o tema pesquisado, as quais foram selecionadas pela leitura seletiva. Entretanto, por não se ter acesso ao resumo de uma delas, apenas 1 foi selecionada para a aplicação do TR1.

A palavra-chave “poluição atmosférica” resultou na indicação de 42 referências, das quais foi selecionada apenas 1 para ser submetida ao TR1.

O uso da palavra-chave "bioacumulação" resultou em 4 referências, as quais não foram selecionadas por não se relacionarem ao tema de nossa pesquisa.

Apenas 2 referências desta base de dados foram encaminhadas para a aplicação do TR1.

\section{Pesquisa informal em acervos particulares}

Nas buscas informais efetuadas nos acervos particulares de pesquisadores da área, aos quais recorremos, foram obtidos 42 artigos científicos sobre o tema desta pesquisa. Desse total, 4 foram excluídos durante a leitura seletiva, por se tratarem de repetições de artigos anteriormente selecionados.

Assim, nas buscas informais, foram selecionados 38 artigos científicos sobre o tema pesquisado, para aplicação do TR1.

Consideramos que a revisão sistemática da literatura, enquanto metodologia de escolha para esta investigação, permitiu um maior aprofundamento sobre a temática de nosso interesse e uma avaliação mais segura sobre o uso de bioindicadores vegetais em processos de avaliação de riscos à saúde humana e ambiental, pela ação de contaminantes atmosféricos em níveis poluentes.

Verificamos variações expressivas nos conteúdos das bases e bancos de dados consultados, confirmando a necessidade de se efetuar uma ampla busca tanto em meios 
eletrônicos, como em acervos não indexados, de forma a garantir a abrangência esperada em pesquisas dessa natureza, a começar da escolha das palavras-chave e/ou descritores de busca.

Discutiremos, a seguir, as particularidades encontradas no processo de busca de estudos efetuados sobre o uso de bioindicadores vegetais relacionados à poluição atmosférica, em situações reais e simuladas em laboratórios.

A palavra-chave utilizada com maior freqüência foi "bioindicator” que, em função da abrangência do conceito nela contido, resultou em um grupo de aproximadamente 4000 títulos. Na tentativa de refinar esta seleção, procuramos associar a ela outros termos relacionados ao tema da pesquisa. Entretanto, o procedimento não possibilitou o refinamento desejado, produzindo um resultado nulo de referências bibliográficas.

Por outro lado, estavam incluídos nos trabalhos levantados grande número de estudos que não tratavam das variáveis de inclusão desta investigação.

Os descritores de assunto utilizados faziam parte de uma relação de descritores previamente estabelecidos pelas bases e bancos de dados consultados. Analisando os resultados obtidos a partir dos descritores utilizados é possível verificar que eles não propiciaram o acesso aos estudos pretendidos, considerando-se a quantidade pouco expressiva de artigos encontrados por esta forma busca.

Das bases de dados consultadas, a que possibilitou o acesso ao maior número de títulos efetivamente incluídos nesta revisão sistemática foi o Biological Abstract, com evidente predomínio de publicações no idioma inglês, em relação aos outros dois idiomas préselecionados. Esta foi a base de dados por onde iniciamos nossas buscas.

A base de dados Medline, provavelmente por conter informações principalmente da área médica, resultou num pequeno número de referências bibliográficas. Além disso, a maioria dos resumos obtidos por esta via já se encontrava abrangida pela base de dados inicialmente consultada. 
Nos bancos e bases de dados nacionais e latino-americanos Lilacs, IBCT e Dedalus, foi possível o acesso a um reduzido número de estudos referentes a nossa área de interesse, demonstrando ser, o tema pesquisado pela presente revisão sistemática da literatura, ainda pouco explorado no Brasil e na América Latina.

A busca efetuada nos acervos particulares de pesquisadores mostrou-se bastante eficaz, podendo ser mais amplamente explorada em outros estudos de mesma natureza, embora, obviamente, não garanta a cobertura das demais fontes de referência. Torna-se de maior importância, se considerarmos que essa via de consulta garantiu o acesso a estudos não abrangidos, em sua totalidade, pelas buscas efetuadas por via eletrônica.

\subsubsection{Aplicação dos testes de relevância TR1 e TR2}

No primeiro teste de relevância (TR1), foram avaliados 279 artigos científicos pelos dois revisores, tomando-se por base os seus resumos. Houve discordância na avaliação dos dois revisores em 28 resumos. Após reavaliação conjunta pelos dois revisores, das discordâncias apresentadas, pela releitura e discussão dos resumos, concluíu-se por 237 inclusões, 39 exclusões e 3 casos de dúvida. Estes casos de dúvida foram incluídos para a aplicação do TR2.

Os motivos de exclusão dos 39 artigos foram: por assunto (23 estudos), pelo tipo de publicação (12 estudos) e pelo idioma (4 estudos).

Assim, resultaram 240 inclusões (ou 86 \% dos resumos analisados) pelo TR1, para aplicação do TR2.

O Quadro 5 traz, de forma resumida, os resultados dos dados coletados nos diferentes bancos e bases de dados consultados, nas buscas informais em acervos particulares, bem como os resultados da aplicação do TR1. 
Quadro 5 - Total de artigos científicos encontrados e total de artigos selecionados, excluídos e com dúvida após aplicação do TR1

\begin{tabular}{|c|c|c|c|c|c|c|c|}
\hline $\begin{array}{c}\text { Base de } \\
\text { dados }\end{array}$ & $\begin{array}{c}\text { Artigos } \\
\text { encontrados }\end{array}$ & $\begin{array}{l}\text { Artigos } \\
\text { excluídos } \\
\text { por } \\
\text { repetição }\end{array}$ & $\begin{array}{c}\text { Artigos } \\
\text { selecionados } \\
\text { para o TR1 }\end{array}$ & $\begin{array}{c}\text { Artigos } \\
\text { excluídos } \\
\text { no TR1 }\end{array}$ & $\begin{array}{c}\text { Artigos } \\
\text { incluídos } \\
\text { no TR1 }\end{array}$ & $\begin{array}{c}\text { Artigos } \\
\text { com } \\
\text { dúvidas } \\
\text { no TR1 }\end{array}$ & $\begin{array}{c}\text { Artigos } \\
\text { selecionados } \\
\text { para o TR2 }\end{array}$ \\
\hline $\begin{array}{c}\text { Biological } \\
\text { Abstract } \\
\text { (inglês) }\end{array}$ & 3695 & 02 & 222 & 25 & 195 & 2 & 197 \\
\hline $\begin{array}{c}\text { Biological } \\
\text { Abstract } \\
\text { (espanhol) }\end{array}$ & 92 & 01 & 04 & 02 & 01 & 01 & 02 \\
\hline MedLine & 166 & 14 & 06 & 0 & 06 & 0 & 06 \\
\hline Agris & 69 & 01 & 05 & 02 & 03 & 0 & 03 \\
\hline Lilacs & 295 & 03 & 01 & 0 & 01 & 0 & 01 \\
\hline Dedalus & 140 & 0 & 01 & 0 & 01 & 0 & 01 \\
\hline$I B I C T$ & 48 & 0 & 02 & 0 & 02 & 0 & 02 \\
\hline Informais & 42 & 04 & 38 & 10 & 28 & 0 & 28 \\
\hline Total & 4547 & 25 & 279 & 39 & 237 & 03 & 240 \\
\hline
\end{tabular}

Após seleção dos 240 estudos resultantes da aplicação do TR1, procedemos à captação dos estudos na íntegra, tendo sido obtidos 154 (64,2 \%) artigos do total selecionado. Não foram localizados 86 estudos, o que representou 35,8 \% de perda de artigos do conjunto de estudos selecionados para a aplicação do TR2.

Do total de artigos na íntegra encontrados, 124 foram obtidos de revistas eletrônicas disponíveis nos portais eletrônicos da CAPES e SIBiNET. Os demais artigos e estudos na íntegra foram assim obtidos: 11 artigos na Biblioteca da Faculdade de Saúde Pública da Universidade de São Paulo; 17 artigos diretamente dos acervos particulares anteriormente 
mencionados; e, 2 foram disponibilizados pelo Sistema de Comutação entre Bibliotecas da Universidade de São Paulo. Nenhum dos periódicos relativos aos artigos selecionados no período considerado, encontrava-se disponível no acervo da Biblioteca Central do Campus Administrativo de Ribeirão Preto, USP, por ocasião do nosso levantamento.

Constatamos que, se de um lado temos a disponibilidade de uma grande variedade de artigos on-line, este recurso ainda não cobre todas as necessidades na área, haja vista que não foram todos os artigos selecionados que estavam disponíveis nos meios eletrônicos.

O número de artigos e estudos obtidos na íntegra variou, também, para as diferentes bases de dados utilizadas nesta pesquisa.

Pela base de dados Biological Abstract, tivemos acesso a 137 artigos na íntegra, dos quais 111 foram incluídos com a aplicação do TR2. Pela base de dados Medline, obtivemos apenas 1 artigo na íntegra, o qual foi excluído com a aplicação do TR2. Não foram encontrados os artigos na íntegra selecionados na base de dados Agris, nem no banco de dados Dedalus. Os 2 estudos selecionados pelo banco de dados do IBICT e o artigo selecionado pela base de dados Lilacs foram obtidos na íntegra e incluídos pelo TR2. Onze artigos obtidos de fontes informais foram incluídos pelo TR2.

A aplicação do TR2 nos 154 estudos selecionados resultou na inclusão de 126 estudos, ou 81,8 \% do total analisado, e a exclusão dos outros 28 estudos, ou 18,2 \% do total analisado.

O quadro 6 traz, de forma resumida, os resultados da aplicação do TR2, segundo o número de estudos e artigos obtidos na íntegra. 
Quadro 6 - Resultados da aplicação do TR2 por base ou banco de dados consultados, segundo o número de artigos obtidos na íntegra

\begin{tabular}{|c|c|c|c|c|c|c|c|c|c|}
\hline \multirow[t]{2}{*}{$\begin{array}{c}\text { Base de } \\
\text { dados }\end{array}$} & \multirow{2}{*}{$\begin{array}{c}\text { Estudos e } \\
\text { artigos } \\
\text { seleciona- } \\
\text { dos pelo } \\
\text { TR1 }\end{array}$} & \multicolumn{2}{|c|}{$\begin{array}{c}\text { Estudos ou artigos } \\
\text { na íntegra não } \\
\text { encontrados }\end{array}$} & \multicolumn{2}{|c|}{$\begin{array}{c}\text { Estudos ou artigos } \\
\text { na íntegra } \\
\text { encontrados }\end{array}$} & \multicolumn{2}{|c|}{$\begin{array}{c}\text { Estudos ou artigos } \\
\text { excluídos pelo } \\
\text { TR2 }\end{array}$} & \multicolumn{2}{|c|}{$\begin{array}{c}\text { Estudos ou artigos } \\
\text { incluídos pelo } \\
\text { TR2 }\end{array}$} \\
\hline & & quantidade & $\%$ & quantidade & $\%$ & quantidade & $\%$ & quantidade & $\%$ \\
\hline $\begin{array}{c}\text { Biological } \\
\text { Abstract } \\
\text { (inglês) }\end{array}$ & 197 & 61 & 31,0 & 136 & 69,0 & 25 & 18,4 & 111 & 81,6 \\
\hline $\begin{array}{l}\text { Biological } \\
\text { Abstract } \\
\text { (espanhol) }\end{array}$ & 02 & 01 & 50,0 & 01 & 50,0 & 1 & 100 & 0 & 0 \\
\hline MedLine & 06 & 05 & 83,3 & 01 & 16,7 & 0 & 0 & 01 & 100 \\
\hline Agris & 03 & 03 & 100 & 0 & 0 & 0 & 0 & 0 & 0 \\
\hline Lilacs & 01 & 0 & 0 & 01 & 100 & 0 & 0 & 01 & 100 \\
\hline Dedalus & 01 & 01 & 100 & 0 & 0 & 0 & 0 & 0 & 0 \\
\hline IBICT & 02 & 0 & 0 & 02 & 100 & 0 & 0 & 02 & 100 \\
\hline Informais & 28 & 15 & 53,6 & 13 & 46,4 & 2 & 15,4 & 11 & 84,6 \\
\hline Total & 240 & 86 & 35,8 & 154 & 64,2 & 28 & 18,2 & 126 & 81,8 \\
\hline
\end{tabular}

Após a definição da seleção final de artigos na íntegra, procedemos à avaliação dos dados contidos nos 126 estudos selecionados, visando o alcance dos objetivos da investigação. Assim, procedemos à sistematização de informações consideradas relevantes, a saber: referência bibliográfica, local de estudo, vegetal empregado, poluente analisado, fonte de emissão, tempo e forma de exposição da planta e parâmetros analisados, que se encontram compiladas no Quadro 7. 
A aplicação dos dois testes de relevância teve caráter fundamental na seleção dos estudos relacionados ao tema da pesquisa. Assim, consideramos que as perguntas condutoras dos testes de relevância devem ser formuladas de modo a expressar com clareza e precisão os objetos da busca, evitando-se o excesso ou a escassez de informações sobre o tema pesquisado, corroborando com Atallah e Castro (1997) e Counsell (1997).

A aplicação do TR1 permitiu uma maior agilidade na pesquisa, resultando em uma quantidade expressiva de exclusões, nessa fase da pesquisa. Entretanto, consideramos que haveria um melhor refinamento no grupo de estudos a serem efetivamente incluídos, caso houvéssemos discriminado os poluentes de nosso interesse já no primeiro instrumento utilizado para a coleta de dados. A ausência deste procedimento resultou no levantamento e leitura de artigos na íntegra que foram posteriormente excluídos, pelo fato de se referirem à ação de poluentes não considerados na presente pesquisa. Neste grupo de poluentes podemos relacionar a amônia, os poluentes orgânicos persistentes (POPs), os bifenil-policlorados (PCBs), os poluentes radioativos, dentre outros, os quais não foram considerados por necessidade de delimitação de conteúdos, bem como pelo enfoque da pesquisa sobre os poluentes mais freqüentemente monitorados pelas agências de controle ambiental brasileira e internacional.

Ainda que não tenham possibilitado o acesso a todos os artigos selecionados, as revistas eletrônicas tiveram importância relevante para a concretização desta pesquisa, visto que cerca de $80 \%$ do total de estudos obtidos, foram por esta via. Esse fato evidencia a importância dessa fonte de dados para estudos de natureza científica, e tão recentemente disponível nos meios acadêmicos. 
Quadro 7 - Síntese dos dados obtidos por Revisão Sistemática da Literatura aplicada para uso de bioindicadores vegetais de poluição atmosférica

\begin{tabular}{|c|c|c|c|c|c|c|c|c|c|c|c|}
\hline Referência & $\begin{array}{l}\text { Local do estudo } \\
\text { Cidade e País }\end{array}$ & Espécie & $\begin{array}{l}\text { Divisão / Ordem } \\
\text { Botânica }\end{array}$ & Hábito & Poluentes & Fonte de poluição & $\begin{array}{c}\text { Exposiç̃ão da planta } \\
\text { ativa/passiva; } \\
\text { laboratório/campo }\end{array}$ & $\begin{array}{l}\text { Tempo de } \\
\text { exposiçãao }\end{array}$ & Parâmetros analisados & $\begin{array}{c}\text { Tipo de } \\
\text { bioindicador } \\
\text { reação/ } \\
\text { acumulação } \\
\end{array}$ & Observações \\
\hline ACETO, M. et al., 2003. & Piedmont, Itália & Bryum argenteum & Briófita, musgo & & \begin{tabular}{|c|} 
Metais: Al, As, Ba, Ca, \\
$\mathrm{Cd}, \mathrm{Co}, \mathrm{Cr}, \mathrm{Cu}, \mathrm{Fe}, \mathrm{K}$, \\
$\mathrm{Li}, \mathrm{Mg}, \mathrm{Mn}, \mathrm{Na}, \mathrm{Ni}, \mathrm{P}$, \\
$\mathrm{Pb}, \mathrm{Sr}, \mathrm{Ti}, \mathrm{Zn}$
\end{tabular} & $\begin{array}{l}\text { rodovias, indústrias, } \\
\text { agricultura }\end{array}$ & passiva & $\begin{array}{c}\text { não } \\
\text { especificado }\end{array}$ & $\begin{array}{l}\text { concentração de metais nas amostras } \\
\text { de musgo expostas }\end{array}$ & acumulação & \\
\hline ADAMO, P. et al., 2003. & Nápoles, Itália & $\begin{array}{l}\text { Sphagnum } \\
\text { capillifolium; } \\
\text { Pseudevernia } \\
\text { furfuracea } \\
\end{array}$ & $\begin{array}{l}\text { Briófita, Musgo } \\
\text { Líquen }\end{array}$ & $\begin{array}{l}\text { epífita } \\
\text { epifita }\end{array}$ & $\begin{array}{c}\text { Metais: } \mathrm{Al}, \mathrm{As}, \mathrm{Cd}, \mathrm{Cr}, \\
\mathrm{Co}, \mathrm{Cu}, \mathrm{Fe}, \mathrm{K}, \mathrm{Mg}, \mathrm{Mn}, \\
\text { Mo, Ni, Pb, Ti, V, Zn }\end{array}$ & $\begin{array}{l}\text { veículos e indústrias } \\
\text { (área urbana) }\end{array}$ & ativa, campo & $\begin{array}{l}10 \text { e } 17 \\
\text { semanas }\end{array}$ & $\begin{array}{c}\text { concentração dos } 17 \text { elementos-traço } \\
\text { em amostras expostas }\end{array}$ & acumulação & $\begin{array}{l}\text { tempo de exposição: } \\
10 \text { semanas - estação } \\
\text { seca ; } 17 \text { semanas- } \\
\text { estação úmida }\end{array}$ \\
\hline $\begin{array}{l}\text { AKOSY, A.; ÖZTÜRK, } \\
\text { M.A., } 1997 .\end{array}$ & Antalya, Turquia & Nerium oleander & Angiosperma & arbustiva & $\begin{array}{c}\text { Metais pesados: } \mathrm{Pb}, \mathrm{Cd}, \\
\mathrm{Zn}, \mathrm{Cu}\end{array}$ & $\begin{array}{l}\text { tráfego de veículos e } \\
\text { barcos }\end{array}$ & passiva & $\begin{array}{c}\text { não } \\
\text { especificado }\end{array}$ & \begin{tabular}{|c|} 
concentração dos metais em folhas de \\
plantas expostas (lavadas e não \\
lavadas); concentração dos metais no \\
solo
\end{tabular} & acumulação & \\
\hline ALAIMO, M.G. et al., 2000. & Palermo, Itália & Pinus pinea & Coniferofita & arbórea & $\begin{array}{l}\text { elementos químicos } \\
\text { inorgânicos }\end{array}$ & $\begin{array}{l}\text { emissões veiculares, } \\
\text { calefação e pequenas } \\
\text { indústrias }\end{array}$ & passiva & $\begin{array}{c}\text { não } \\
\text { especificado }\end{array}$ & \begin{tabular}{|c|}
$\begin{array}{c}\text { concentração dos } 20 \text { elementos } \\
\text { químicos; composição isotópica do Pb } \\
\text { (planta e solo); alteraçōes anatôomicas } \\
\text { (presenças de fenóis) }\end{array}$ \\
\end{tabular} & acumulação & \\
\hline ALESSIO, M. et al., 2002. & $\begin{array}{l}\text { Roma e Lazio (rural), } \\
\text { Itália }\end{array}$ & Quercus ilex & Angiosperma & arbórea & Chumbo, CO2 & $\begin{array}{l}\text { veículos, ambiente } \\
\text { urbano }\end{array}$ & passiva & 3 anos & \begin{tabular}{|c|} 
composição de isótopos estáveis do \\
$\mathrm{Pb}$; concentração Pb; trocas gasosas \\
folhas; clorofila
\end{tabular} & acumulação & \\
\hline ALESSIO, M. et al., 2002. & $\begin{array}{l}\text { Roma e Lazio (rural), } \\
\text { Itália }\end{array}$ & Pinus pinea & Coniferofita & arbórea & Chumbo, CO2 & $\begin{array}{l}\text { veículos, ambiente } \\
\text { urbano }\end{array}$ & passiva & 3 anos & $\begin{array}{l}\text { composiç̃ã de isótopos estáveis do } \\
\text { Pb; concentração Pb; trocas gasosas } \\
\text { folhas; clorofila } \\
\end{array}$ & acumulação & \\
\hline ALVES, E.S. et al., 2001. & São Paulo, Brasil & $\begin{array}{l}\text { Tradescantia } \\
\text { clone } 4430\end{array}$ & Angiosperma & herbácea & SO2, NOx, O3 & veículos & ativa, campo & 3 meses & $\begin{array}{c}\mathrm{n}^{0} \text { estômatosos e células epidérmicas; } \\
\text { diâmetro do metaxilema (nervura } \\
\text { central); dimensones da câmara } \\
\text { estomática; espessura da lâmina } \\
\text { foliar; altura das células do mesófilo } \\
\text { (anatômicos) } \\
\end{array}$ & reação & \\
\hline $\begin{array}{l}\text { AMADO FILHO, G.M. et al., } \\
2002\end{array}$ & Rio de Janeiro, Brasil & $\begin{array}{l}\text { Tillandsia } \\
\text { usneoides }\end{array}$ & Angiosperma & $\begin{array}{c}\text { epífita } \\
\text { (bromélia) }\end{array}$ & $\mathrm{Hg}$ & industrial & ativa, campo & 15 dias & $\begin{array}{l}\text { concentração de dg nas amostras } \\
\text { coletadas; detecção do metal com } \\
\text { microscópio eletrônico }\end{array}$ & acumulação & $\begin{array}{c}\text { Espécie apropriada } \\
\text { para uso em regiões } \\
\text { mais tropicais, em } \\
\text { substituição a líquens, } \\
\text { musgos e coníferas } \\
\end{array}$ \\
\hline $\begin{array}{l}\text { ARUTYUNYAN, R.M. et } \\
\text { al.,1999 }\end{array}$ & Yerevan, Armenia & $\begin{array}{l}\text { Tradescantia } \\
\text { clone } 02\end{array}$ & Angiosperma & herbácea & não especificado & industrial & ativa, campo & $\begin{array}{c}\text { não } \\
\text { especificado }\end{array}$ & $\begin{array}{l}\text { Tradescantia-SHM: eventos de } \\
\text { mutação em células de pelos } \\
\text { estamínicos de plantas expostas }\end{array}$ & reação & \\
\hline BATALHA, J.R.F. et al.,1999 & São Paulo, Brasil & $\begin{array}{c}\text { Tradescanlia } \\
\text { pallida var } \\
\text { purpurea }\end{array}$ & Angiosperma & herbácea & PM-10 & veículos & ativa, laboratório & & $\begin{array}{l}\text { mutagenicidade pela formação de } \\
\text { micronúcleos (Trad-MCN) }\end{array}$ & reação & \\
\hline $\begin{array}{l}\text { BAUR, M.; LAUCHERT, U.; } \\
\text { WILD A., } 1998\end{array}$ & $\begin{array}{l}\text { Alemanha (várias } \\
\text { localidades) }\end{array}$ & Picea abies & Coniferofita & arbórea & $\mathrm{O} 3$ & não especificado & passiva & 2 anos & \begin{tabular}{|c|} 
clorofila a e b, proteína DI, citocromo \\
e P700
\end{tabular} & reação & \\
\hline BEDNÁROVÁ, E., 2001. & República Tcheca & Betula pendula & Angiosperma & arbórea & SO2 & industrial & passiva & $\begin{array}{c}\text { não } \\
\text { especificado }\end{array}$ & \begin{tabular}{|c|} 
alterações estruturais e quantitativas \\
na área epicuticular das folhas \\
\end{tabular} & reação & \\
\hline $\begin{array}{l}\text { BERG, T.; STEINNES, E., } \\
1997 \mathrm{~b}\end{array}$ & $\begin{array}{l}\text { Noruega (várias } \\
\text { localidades) }\end{array}$ & $\begin{array}{l}\text { Hylocomium } \\
\text { splendens; } \\
\text { Pleurozium } \\
\text { schereberi } \\
\end{array}$ & Briófita, musgo & & $\begin{array}{l}\text { elementos-traço e } \\
\text { elementos químicos de } \\
\text { deposição aérea (MP) }\end{array}$ & não especificado & passiva & 2 anos & \begin{tabular}{|c|} 
concentração dos elementos-traço nas \\
amostras dos musgos e conversãa \\
para taxa de deposição (regressão \\
linear)
\end{tabular} & acumulação & \\
\hline $\begin{array}{l}\text { BERG, T.; STEINNES, } \\
\text { E.,1997a }\end{array}$ & Noruega & $\begin{array}{l}\text { Hylocomium } \\
\text { splendens }\end{array}$ & Briófita, musgo & & elementos-traço & $\begin{array}{l}\text { transporte aéreo de } \\
\text { partículas } \\
\text { provenientes de } \\
\text { longas distâncias }\end{array}$ & passiva & 3 anos & \begin{tabular}{|c|} 
concentração dos elementos-traço em \\
amostras de musgo expostas
\end{tabular} & acumulação & $\begin{array}{c}\text { Fontes locais de } \\
\text { poluição: indústrias } \\
\text { metalúrgicas de } \\
\text { Níquel, Zinco e } \\
\text { Cromo } \\
\end{array}$ \\
\hline
\end{tabular}




\begin{tabular}{|c|c|c|c|c|c|c|c|c|c|c|c|}
\hline Referência & $\begin{array}{l}\text { Local do estudo } \\
\text { Cidade e País }\end{array}$ & Espécie & $\begin{array}{c}\text { Divisão / Ordem } \\
\text { Botânica }\end{array}$ & Hábito & Poluentes & Fonte de poluição & \begin{tabular}{|c|} 
Exposição da planta \\
ativa/passiva; \\
laboratório/campo
\end{tabular} & $\begin{array}{l}\text { Tempo de } \\
\text { exposição }\end{array}$ & Parâmetros analisados & $\begin{array}{c}\text { Tipo de } \\
\text { bioindicador } \\
\text { reação/ } \\
\text { acumulação }\end{array}$ & Observações \\
\hline BLUM, O. et al., 1997. & $\begin{array}{l}\text { Montes Cárpatos e } \\
\text { região de Kiev } \\
\text { Ucrânia }\end{array}$ & $\mid$\begin{tabular}{|c|} 
Nicotiana tabacum \\
Bel-W3 (sensivel) e \\
Bel-B (resistente)
\end{tabular} & Angiosperma & arbustiva & Ozônio (O3) & $\begin{array}{c}\text { tráfego de veículos; } \\
\text { transporte de } \\
\text { poluentes de grandes } \\
\text { distâncias } \\
\end{array}$ & ativa, campo & 14 dias & $\begin{array}{l}\text { concentração de O3 na troposfera; } \\
\text { injúrias foliares }\end{array}$ & reação & \\
\hline BÖHM, P. et al.,1998 & $\begin{array}{l}\text { Bohemia, República } \\
\text { Tcheca }\end{array}$ & $\begin{array}{l}\text { Quercus robur; } \\
\text { Quercus petrae }\end{array}$ & Angiosperma & arbórea & \begin{tabular}{|c|} 
Metais: Al, As, Ce, Co, Cr, \\
Cs, Fe, Hf, Hg, La, Mn, \\
Na, Ni, Rb, S, Sb, Sc, Se, \\
Th, Ti, U, V, W, Zn
\end{tabular} & $\begin{array}{l}\text { industrial, urbana e } \\
\text { natural }\end{array}$ & passiva & $\begin{array}{c}\text { não } \\
\text { especificado }\end{array}$ & $\begin{array}{c}\text { concentração dos elementos químicos } \\
\text { em amostras de casca das espécies } \\
\text { selecionadas }\end{array}$ & acumulação & \\
\hline BORTIER et al., 2001 & Terverum, Bélgica & Populus nigra & Angiosperma & arbórea & $\mathrm{O} 3$ & não especificada & ativa, campo & 5 meses & $\begin{array}{l}\text { injúrias foliares, conc. clorofila, taxa } \\
\text { de crescimento }\end{array}$ & reação & \\
\hline BRIGHIGNA, L. et al., 1997. & São José, Costa Rica & $\begin{array}{l}\text { Tillandsia caput- } \\
\text { medusae }\end{array}$ & Angiosperma & $\begin{array}{c}\text { epífita } \\
\text { (bromélia) }\end{array}$ & $\mathrm{Pb}, \mathrm{Cd}$ e $\mathrm{Cu}$ & veículos, indústrias & passiva & 20 meses & concentração de Pb, Cu, Cd na planta & acumulação & $\begin{array}{c}\text { Espécie com ampla } \\
\text { distribuição na } \\
\text { América do Sul e Sul } \\
\text { dos EUA } \\
\end{array}$ \\
\hline BRIGHIGNA, L. et al., 2002. & Florença, Itália & $\begin{array}{c}\text { Tillandsia caput- } \\
\text { medusae } \\
\text { Tillandsia bulbosa }\end{array}$ & Angiosperma & $\begin{array}{l}\text { epífita } \\
\text { (bromélia) }\end{array}$ & PAHs & não especificado & ativa, campo & 9 meses & $\begin{array}{c}\text { concentrações de PAHs, alterações na } \\
\text { superfície foliar }\end{array}$ & acumulação & $\begin{array}{c}\text { Espécie com ampla } \\
\text { distribuição na } \\
\text { América do sul e Sul } \\
\text { dos EUA }\end{array}$ \\
\hline BRÜMELIS, G. et al., 1999. & Lituânia & $\begin{array}{l}\text { Hylocomium } \\
\text { splendens }\end{array}$ & Briófita, Musgo & & $\mathrm{Zn}, \mathrm{Pb}$ e Cu & metalúrgica & passiva & $\begin{array}{c}\text { não } \\
\text { especificado }\end{array}$ & $\begin{array}{c}\text { concentração dos elementos em } \\
\text { amostras do musgo }\end{array}$ & acumulação & \\
\hline BRÜMELIS, G. et al., 1999. & Lituânia & $\begin{array}{l}\text { Hylocomium } \\
\text { splendens }\end{array}$ & Briófita, Musgo & & $\mathrm{Zn}$ & metalúrgica & passiva & $\begin{array}{c}\text { não } \\
\text { especificado }\end{array}$ & concentração intra-celular de Zn & reação & \\
\hline BULBOVAS, P., 2000. & Cubatão, (SP), Brasil & Euterpe edulis & Angiosperma & arbórea & $\begin{array}{l}\text { mistura complexa de } \\
\text { poluentes }\end{array}$ & industrial & ativa & 3 meses & \begin{tabular}{|c|} 
porcentagem de germinação; medidas \\
de crescimento; peso seco; \\
concentrações de flúor, macro e micro \\
nutrientes nas folhas, chuva e solo \\
\end{tabular} & reação & \\
\hline $\begin{array}{l}\text { CALASANS, C.F.; MALM. } \\
\text { O., } 1997\end{array}$ & Rio de Janeiro, Brasil & $\begin{array}{l}\text { Tillandsia } \\
\text { usneoides }\end{array}$ & Angiosperma & $\begin{array}{l}\text { epífita } \\
\text { (bromélia) }\end{array}$ & $\mathrm{Hg}$ & indústria (cloro-alcali) & ativa, campo & $\begin{array}{l}15,20,38 \text { e } 68 \\
\text { dias }\end{array}$ & \begin{tabular}{|c|} 
concentracasão de Hg em partes jovens \\
e adultas de amostras da planta \\
expostas
\end{tabular} & acumulação & \\
\hline CALZADA, I. et al., 2001. & $\begin{array}{l}\text { Vale o Rio Altube, } \\
\text { Espanha }\end{array}$ & Pinus radiata & Coniferofita & arbórea & $\mathrm{O} 3$ & não especificado & passiva & $\begin{array}{c}\text { não } \\
\text { especificado }\end{array}$ & \begin{tabular}{|c|} 
parâmetros bioquímicos: atividade da \\
enzima peroxidase, conteúdo de \\
ascorbato e sulfidril
\end{tabular} & reação & \begin{tabular}{|c|} 
Locais dos \\
experimentos situados \\
em zona rural \\
\end{tabular} \\
\hline $\begin{array}{c}\text { CARIGNAN, J.; } \\
\text { SIMONETTI, A.; GARIÉPY, } \\
\text { C., 2002. }\end{array}$ & \begin{tabular}{|c|} 
USA - St. Lawrence \\
Valey; Canadá - \\
províncias marítimas
\end{tabular} & $\begin{array}{l}\text { Usnea sp; Bryoria } \\
\text { sp; Evernia sp }\end{array}$ & Líquen & epífita & $\mathrm{Pb}$ & $\begin{array}{l}\text { indústrias; atividade } \\
\text { urbana }\end{array}$ & passiva & 2 anos & composição de isótopos estáveis $\mathrm{Pb}$ & acumulação & \\
\hline $\begin{array}{c}\text { CARIGNAN, J.; } \\
\text { SIMONETTI, A.; GARIÉPY, } \\
\text { C., 2002. }\end{array}$ & \begin{tabular}{|c|} 
Canadá - floresta \\
boreal da Província de \\
Quebec
\end{tabular} & \begin{tabular}{|c|} 
Usnea sp; Bryoria \\
sp; Evernia sp \\
\end{tabular} & Líquen & epífita & $\mathrm{Pb}$ & $\begin{array}{c}\text { minas de extração de } \\
\text { Pb }\end{array}$ & passiva & 2 anos & composição de isótopos estáveis $\mathrm{Pb}$ & acumulação & \\
\hline $\begin{array}{c}\text { CARRERAS, H.A.; } \\
\text { PIGNATA, M.L., } 2001 \\
\end{array}$ & Córdoba, Argentina & Usnea amblyoclada & Líquen & & não especificado & veículos, industrial & ativa, campo & & $\begin{array}{c}\text { peso seco, peso úmido, clorofila, } \\
\text { produtos da oxidação }\end{array}$ & reação & \\
\hline $\begin{array}{l}\text { CEBURNIS, D.; STEINNES, } \\
\text { E.; KVIETKUS. K., 1999. }\end{array}$ & Lituânia & $\begin{array}{l}\text { Hylocomium } \\
\text { splendes }\end{array}$ & Briófita, musgo & & $\mathrm{Pb}, \mathrm{Cd}, \mathrm{Cu}$ & não especificado & passiva & 2 meses & $\begin{array}{c}\text { concentração dos elementos químicos } \\
\text { no musgo e na água da chuva }\end{array}$ & acumulação & \\
\hline $\begin{array}{l}\text { CEBURNIS, D.; STEINNES, } \\
\text { E.; KVIETKUS. K., } 1999 .\end{array}$ & Lituânia & $\begin{array}{l}\text { Pleurozium } \\
\text { schreberi }\end{array}$ & Briófita, musgo & & $\mathrm{Pb}, \mathrm{Cd}, \mathrm{Cu}$ & não especificado & passiva & 2 meses & $\begin{array}{c}\text { concentração dos elementos químicos } \\
\text { no musgo e na água da chuva }\end{array}$ & acumulação & \\
\hline $\begin{array}{l}\text { CEBURNIS, D.; STEINNES, } \\
\text { E.; KVIETKUS. K., } 1999 .\end{array}$ & Lituânia & $\begin{array}{l}\text { Eurhynchium } \\
\text { angustirete }\end{array}$ & Briófita, musgo & & $\mathrm{Pb}, \mathrm{Cd}, \mathrm{Cu}$ & não especificado & passiva & 2 meses & $\begin{array}{c}\text { concentração dos elementos químicos } \\
\text { no musgo e na água da chuva }\end{array}$ & acumulação & \\
\hline $\begin{array}{c}\text { CEBURNIS, D.; STEINNES. } \\
\text { E., } 2000\end{array}$ & Lituânia & Picea abies & Coniferofita & arbórea & $\begin{array}{c}\text { metais pesados: As, } \mathrm{Cd}, \\
\mathrm{Cr}, \mathrm{Mn}, \mathrm{Pb}, \mathrm{V}, \mathrm{Zn}\end{array}$ & não especificado & passiva & $\begin{array}{c}\text { não } \\
\text { especificado }\end{array}$ & \begin{tabular}{c|} 
concentração dos metais em acículas e \\
parte vegetativa de líquens
\end{tabular} & \begin{tabular}{|c|} 
espécie não \\
recomendada \\
como bioindicador
\end{tabular} & $\begin{array}{c}\text { concentrações muito } \\
\text { baixas de poluentes } \\
\text { nas acículas - análises } \\
\text { químicas mais raras e } \\
\text { difíceis } \\
\end{array}$ \\
\hline $\begin{array}{c}\text { CEBURNIS, D.; STEINNES. } \\
\text { E., } 2000\end{array}$ & Lituânia & $\begin{array}{l}\text { Juniperus } \\
\text { communis }\end{array}$ & Coniferofita & arbórea & $\begin{array}{c}\text { metais pesados: } \mathrm{As}, \mathrm{Cd}, \\
\mathrm{Cr}, \mathrm{Mn}, \mathrm{Pb}, \mathrm{V}, \mathrm{Zn}\end{array}$ & não especificado & passiva & $\begin{array}{c}\text { não } \\
\text { especificado }\end{array}$ & $\begin{array}{c}\text { concentração dos metais em acículas e } \\
\text { parte vegetativa de líquens }\end{array}$ & \begin{tabular}{|c|} 
espécie não \\
recomendada \\
como bioindicador
\end{tabular} & \begin{tabular}{|c|} 
concentrações muito \\
baixas de poluentes - \\
análises químicas \\
mais raras e difíceis
\end{tabular} \\
\hline
\end{tabular}




\begin{tabular}{|c|c|c|c|c|c|c|c|c|c|c|c|}
\hline Referência & $\begin{array}{l}\text { Local do estudo } \\
\text { Cidade e País }\end{array}$ & Espécie & $\begin{array}{c}\text { Divisão / Ordem } \\
\text { Botânica }\end{array}$ & Hábito & Poluentes & Fonte de poluição & \begin{tabular}{|c|}
$\begin{array}{c}\text { Exposição da planta } \\
\text { ativa/passiva; } \\
\text { laboratório/campo }\end{array}$ \\
\end{tabular} & $\begin{array}{l}\text { Tempo de } \\
\text { exposição }\end{array}$ & Parâmetros analisados & $\begin{array}{c}\text { Tipo de } \\
\text { bioindicador } \\
\text { reação/ } \\
\text { acumulação }\end{array}$ & Observações \\
\hline $\begin{array}{l}\text { CHAPPELKA, A. et al., } \\
1997 .\end{array}$ & $\begin{array}{l}\text { Great Smoky } \\
\text { Montains National } \\
\text { Park, USA }\end{array}$ & $\begin{array}{l}\text { Prunus serotina; } \\
\text { Asclepias exaltata }\end{array}$ & Angiosperma & $\begin{array}{l}\text { arbórea } \\
\text { arbustiva }\end{array}$ & $\mathrm{O} 3$ & não especificado & passiva & $\begin{array}{c}\text { não } \\
\text { especificado }\end{array}$ & \begin{tabular}{|c|} 
Presença de injúrias foliares: \\
porcentagem de área foliar com \\
injứrias; porcentagem de plantas com \\
injúrias
\end{tabular} & reação & \\
\hline CLAIR ST. et al., 2002. & USA & $\begin{array}{l}\text { Flavoparmelia } \\
\text { caperata }\end{array}$ & Líquen & pedras & $\mathrm{Cu}$ & industrialização & passiva & 3 meses & $\begin{array}{c}\text { concentração de Cu e Zn nas amostras } \\
\text { de: líquen, solo e substrato (pedra, } \\
\text { casaca de árvores) }\end{array}$ & acumulação & $\begin{array}{l}\text { monitoramento } \\
\text { convencional da } \\
\text { qualidade do ar - } \\
\text { registros de } 94 \text { a } 98\end{array}$ \\
\hline CLAIR ST. et al., 2002. & USA & $\begin{array}{l}\text { Flavopunctelia } \\
\text { flaventior }\end{array}$ & Líquen & epífita & $\mathrm{Cu}$ & industrialização & passiva & 3 meses & $\begin{array}{c}\text { concentração de Cu e Zn nas amostras } \\
\text { de: líquen, solo e substrato (pedra, } \\
\text { casaca de árvores) }\end{array}$ & acumulação & $\begin{array}{l}\text { monitoramento } \\
\text { convencional da } \\
\text { qualidade do ar - } \\
\text { registros de } 94 \text { a } 98\end{array}$ \\
\hline CLAIR ST. et al., 2002. & USA & Usnea amblyoclada & Líquen & pedra & $\mathrm{Cu}$ & indústria metalúrgica & passiva & $\begin{array}{c}\text { não } \\
\text { especificado }\end{array}$ & $\begin{array}{c}\text { concentração de Cu e Zn nas amostras } \\
\text { de: líquen, solo e substrato (pedra, } \\
\text { casaca de árvores) }\end{array}$ & acumulação & $\begin{array}{c}\text { monitoramento } \\
\text { convencional da } \\
\text { qualidade do ar - } \\
\text { registros de } 94 \text { a } 98 \\
\end{array}$ \\
\hline CLAIR ST. et al., 2002. & USA & Usnea hirta & Líquen & epífita & $\mathrm{Cu}$ & indústria metalúrgica & passiva & $\begin{array}{c}\text { não } \\
\text { especificado }\end{array}$ & \begin{tabular}{|c}
$\begin{array}{c}\text { concentração de Cu e Zn nas amostras } \\
\text { de: líquen, solo e substrtato (pedra, } \\
\text { casaca de árvores) }\end{array}$ \\
\end{tabular} & acumulação & $\begin{array}{c}\text { monitoramento } \\
\text { convencional da } \\
\text { qualidade do ar - } \\
\text { registros de } 94 \text { a } 98 \\
\end{array}$ \\
\hline $\begin{array}{l}\text { DOBBEN van, H.F.; BRAAK } \\
\text { ter, C.J.F., } 1999 .\end{array}$ & Holanda & 75 espécies nativas & Líquen & epífita & $\mathrm{SO} 2, \mathrm{NO} 2, \mathrm{NH} 3$ & não especificada & passiva & $\begin{array}{c}\text { não } \\
\text { especificado }\end{array}$ & \begin{tabular}{|c} 
presença e abundância de 65 spp de \\
líquens epífitas; dados de qualidade \\
do ar para SO2, NO2 e NH3 \\
\end{tabular} & reação & \\
\hline $\begin{array}{l}\text { DOBBEN van, H.F. et al., } \\
2001\end{array}$ & Holanda & várias espécies & Líquen & epífita & $\begin{array}{l}\text { SO2, NO2, NH3 e } \\
\text { elementos-traço }\end{array}$ & não especificado & passiva & $\begin{array}{c}\text { não } \\
\text { especificado }\end{array}$ & \begin{tabular}{|c|} 
estimativa de abundância de espécies \\
encontradas em troncos de arvvores; \\
concentração de elementos-traço, \\
NO3, NH4 e SO4 nas amostras de \\
cascas de árvores; concentração \\
atmosférica dos poluentes: SO2, NO2 \\
e NH3 \\
\end{tabular} & acumulação & \\
\hline $\begin{array}{l}\text { DOMINGOS, M.; KLUMPP, } \\
\text { A.; KLUMPP, G. , } 1998 .\end{array}$ & Cubatão, Brasil & Miconia pyrifolia & Angiosperma & arbórea & Metais & industrial & passiva & & \begin{tabular}{|c|} 
peroxidase, conc. ácido ascórbico, $\mathrm{pH}$ \\
e poder tampão de extrato de folhas, \\
conc F, Al, macro e micro nutrientes, \\
crescimento
\end{tabular} & não evidenciado & \\
\hline $\begin{array}{l}\text { DOMINGOS, M.; KLUMPP, } \\
\text { A.; KLUMPP, G., } 1998 .\end{array}$ & Cubatão, Brasil & Tibouchina pulchra & Angiosperma & arbórea & F e metais & industrial & ativa e passiva; campo & & $\begin{array}{l}\text { concentração dos poluentes em } \\
\text { tecidos das folhas }\end{array}$ & acumulação & $\begin{array}{l}\text { A espécie pode ser } \\
\text { considerada comoo } \\
\text { tolerante à poluição } \\
\text { do ar, pela alta } \\
\text { capacidade de } \\
\text { sobrevivência em } \\
\text { locais polúídos }\end{array}$ \\
\hline $\begin{array}{l}\text { DOMINGOS, M.; KLUMPP, } \\
\text { A.; KLUMPP, G., } 1998 . \\
\end{array}$ & Cubatão, Brasil & Nicotiana tabacum & Angiosperma & arbustiva & O3 PAN & industrial & ativa, campo & & injúrias nas folhas (necrose) & reação & \\
\hline $\begin{array}{l}\text { DOMINGOS, M.; KLUMPP, } \\
\text { A.; KLUMPP, G., } 1998 . \\
\end{array}$ & Cubatão, Brasil & Urtica urens & Angiosperma & herbácea & O3, PAN & industrial & ativa, campo & & injúrias nas follhas (necrose) & reação & \\
\hline $\begin{array}{l}\text { DOMINGOS, M.; KLUMPP, } \\
\text { A.; KLUMPP, G., } 1998 . \\
\end{array}$ & Cubatão, Brasil & $\begin{array}{c}\text { Gladiolo, } \\
\text { Hemerocalis } \\
\end{array}$ & Angiosperma & herbácea & $\mathrm{F}$ & industrial & ativa, campo & & $\begin{array}{c}\text { concentração dos poluentes, injúrias } \\
\text { na planta }\end{array}$ & $\begin{array}{c}\text { reação, } \\
\text { acumulação }\end{array}$ & \\
\hline $\begin{array}{l}\text { DOMINGOS, M.; KLUMPP, } \\
\text { A.; KLUMPP, G., } 1998 .\end{array}$ & Cubatão, Brasil & Lolium multiflorum & Angiosperma & herbácea & Metais & industrial & ativa, campo & & $\begin{array}{c}\text { peroxidase, conc. ácido ascórbico, } \mathrm{pH} \\
\text { e poder tampão de extrato de folhas, } \\
\text { conc F, Al, macro e micro nutrientes, } \\
\text { crescimento }\end{array}$ & acumulação & \\
\hline
\end{tabular}




\begin{tabular}{|c|c|c|c|c|c|c|c|c|c|c|c|}
\hline Referência & $\begin{array}{l}\text { Local do estudo } \\
\text { Cidade e País }\end{array}$ & Espécie & $\begin{array}{c}\text { Divisão / Ordem } \\
\text { Botânica }\end{array}$ & Hábito & Poluentes & Fonte de poluição & $\begin{array}{c}\text { Exposição da planta } \\
\text { ativa/passiva; } \\
\text { laboratório/campo }\end{array}$ & $\begin{array}{l}\text { Tempo de } \\
\text { exposição }\end{array}$ & Parâmetros analisados & $\begin{array}{c}\text { Tipo de } \\
\text { bioindicador } \\
\text { reação/ } \\
\text { acumulação }\end{array}$ & Observações \\
\hline $\begin{array}{l}\text { DOMINGOS, M.; KLUMPP, } \\
\text { A.; KLUMPP, G., } 1998 .\end{array}$ & Cubatão, Brasil & Miconia саbucu & Angiosperma & arbórea & Metais & industrial & passiva & & $\begin{array}{l}\text { peroxidase, conc. ácido ascórbico, pH } \\
\text { e poder tampão de extrato de folhas, } \\
\text { conc. F, Al, macro e micro nutrientes, } \\
\text { crescimento }\end{array}$ & não evidenciado & \\
\hline $\begin{array}{l}\text { DOMINGOS, M.; KLUMPP, } \\
\text { A.; KLUMPP, G., } 1998 .\end{array}$ & Cubatão, Brasil & Cecropia glaziovi & Angiosperma & arbórea & Metais & industrial & passiva & & \begin{tabular}{|c|} 
peroxidase, conc. ácido ascórbico, $\mathrm{pH}$ \\
e poder tampão de extrato de folhas, \\
conc. F, Al, macro e micro nutrientes, \\
crescimento
\end{tabular} & não evidenciado & \\
\hline $\begin{array}{c}\text { DONGARRÀ, G.; } \\
\text { VARRICA. D., } 1998 \\
\end{array}$ & Ilha Vulcano, Itália & Parmelia sp & Líquen & rochas & Metais & $\begin{array}{c}\text { Emissão de material } \\
\text { particulado de vulcão }\end{array}$ & passiva & $\begin{array}{c}\text { não } \\
\text { especificado }\end{array}$ & $\begin{array}{c}\text { concentração dos metais em amostras } \\
\text { de líquens expostos }\end{array}$ & acumulação & \\
\hline EL-HASAN, T. et al., 2002. & Amman, Jordânia & $\begin{array}{l}\text { Cupressus } \\
\text { sempervirens }\end{array}$ & Coniferofita & arbórea & $\begin{array}{l}\text { Metais: } \mathrm{Cd}, \mathrm{Co}, \mathrm{Cr}, \mathrm{Mg} \text {, } \\
\text { Fe, Cu, Ni, Pb, Zn }\end{array}$ & $\begin{array}{c}\text { veicular; calefação } \\
\text { com óleo combustível, } \\
\text { industrial }\end{array}$ & passiva & $\begin{array}{c}\text { não } \\
\text { especificado }\end{array}$ & $\begin{array}{c}\text { concentração dos metais em casca da } \\
\text { espécie escolhida }\end{array}$ & acumulação & \\
\hline $\begin{array}{l}\text { FAUS-KESSLER, T. et al., } \\
2000 .\end{array}$ & Bavária, Alemanha & $\begin{array}{c}\text { Hypnum } \\
\text { cupressiforme }\end{array}$ & Briófita, Musgo & epífita & $\begin{array}{l}\text { Metais: Al, Ti, V, Cr, } \\
\text { Mn, Fe, Ni, Cu, Zn, As, } \\
\text { Cd, Sb, Hg, Pb }\end{array}$ & não especificada & passiva & $\begin{array}{c}\text { não } \\
\text { especificado }\end{array}$ & $\begin{array}{c}\text { concentração de metais nas amostras } \\
\text { de musgo coletadas }\end{array}$ & acumulação & \\
\hline $\begin{array}{c}\text { FERNÁNDEZ, J.A.; } \\
\text { ABOAL, J.R.; } \\
\text { CARBALLEIRA. A., } 2000 \\
\end{array}$ & Pontevedra, Espanha & $\begin{array}{c}\text { Scleropodium } \\
\text { purum; Hypnum } \\
\text { cupressiforme }\end{array}$ & Briófita, Musgo & & $\mathrm{Hg}$ & $\begin{array}{l}\text { industrial } \\
\text { (cloro-alcali) }\end{array}$ & passiva & 30 dias & $\begin{array}{l}\text { concentração de Hg nas amostras } \\
\text { expostas de musgo }\end{array}$ & acumulação & \\
\hline $\begin{array}{c}\text { FERNÁNDEZ, J.A.; } \\
\text { ABOAL, J.R.; } \\
\text { CARBALLEIRA. A., } 2000\end{array}$ & Pontevedra, Espanha & $\begin{array}{l}\text { Scleropodium } \\
\text { purum }\end{array}$ & Briófita, Musgo & & $\mathrm{Hg}$ & $\begin{array}{l}\text { industrial } \\
\text { (cloro-alcali) }\end{array}$ & ativa, campo & 30 dias & $\begin{array}{l}\text { concentração de Hg nas amostras } \\
\text { expostas de musgo }\end{array}$ & acumulação & \\
\hline $\begin{array}{l}\text { FERNÁNDEZ, J.A.; } \\
\text { CARBALLEIRA, A., } 2000\end{array}$ & Espanha (Galicia) & $\begin{array}{l}\text { Scleropodium } \\
\text { purum }\end{array}$ & Briófita, musgo & & $\begin{array}{l}\text { Metais: Co, Cr, Cu, K, } \\
\text { Ni, Pb e Zn }\end{array}$ & $\begin{array}{l}\text { Termoelétrica a } \\
\text { carvão mineral }\end{array}$ & passiva e ativa, campo & 28 e 56 dias & $\begin{array}{l}\text { concentração dos elementos em } \\
\text { musgos nativos e transplantados }\end{array}$ & acumulação & $\begin{array}{c}\text { comparação dos } \\
\text { resultados para } \\
\text { musgos nativos e } \\
\text { musgos } \\
\text { transplantados, para } \\
\text { identificar possíveis } \\
\text { mecanismos de } \\
\text { adaptacão( (menores } \\
\text { concentraçóes) }\end{array}$ \\
\hline FERREIRA, M.I. et al, 2000. & São Paulo, Brasil & $\begin{array}{c}\text { Tradescantia } \\
\text { clone } 4430\end{array}$ & Angiosperma & herbácea & variável & incinerador & ativa, campo & 5 meses & $\begin{array}{c}\text { Mutação em DNA de células-mãe de } \\
\text { pólen (Trad. - SHM) }\end{array}$ & reação & \\
\hline FERREIRA, M.I. et al., 2003. & São Paulo, Brasil & $\begin{array}{l}\text { Tradescantia } \\
\text { clone } 4430\end{array}$ & Angiosperma & herbácea & $\mathrm{CO}, \mathrm{SO} 2, \mathrm{NO} 2, \mathrm{MP}$ & veículos & ativa, campo & 7 meses & $\begin{array}{l}\text { mutação em células-mãe de pólen } \\
\text { (Trad - SHM) }\end{array}$ & reação & \begin{tabular}{|c|}
$\begin{array}{c}\text { Forte correlação entre } \\
\text { concentração de MP e } \\
\text { frequiência de } \\
\text { mutaçõos }\end{array}$ \\
\end{tabular} \\
\hline $\begin{array}{l}\text { FIGUEIRA, R.; SÉRGIO, C.; } \\
\text { SOUSA, A.J., } 2002 .\end{array}$ & $\begin{array}{l}\text { Portugal (todo o } \\
\text { território) }\end{array}$ & $\begin{array}{c}\text { Hypnum } \\
\text { cupressiforme; } \\
\text { Scelopodium } \\
\text { touretii } \\
\end{array}$ & Briófita, musgo & & $\begin{array}{c}\mathrm{Cd}, \mathrm{Cr}, \mathrm{Cu}, \mathrm{Fe}, \mathrm{Mn}, \mathrm{Ni}, \\
\text { Pb, Zn }\end{array}$ & $\begin{array}{c}\text { natural (solo) e } \\
\text { antrópica (indústrias } \\
\text { etc) }\end{array}$ & passiva & $\begin{array}{c}\text { não } \\
\text { especificado }\end{array}$ & $\begin{array}{l}\text { concentração de elementos em } \\
\text { amostras de musgos e solo }\end{array}$ & acumulação & \\
\hline GARTY, J. et al., 1998. & Ashdad, Israel & Ramalina duriaei & Líquen & epífita & $\begin{array}{l}\text { SO2 e metais: K, B, Al, } \\
\text { Cr, Fe, Si, Ti, Zn, P, } \\
\text { Ba, Cu, Mg, Na, Pb, } \\
\text { Ca, Mn, Sr }\end{array}$ & industrial e veículos & ativa, campo & 10 meses & $\begin{array}{l}\text { concentração de S e demais } \\
\text { elementos, em amostras de liquens } \\
\text { expostos] }\end{array}$ & acumulação & \\
\hline GARTY, J. et al., 2002. & $\begin{array}{c}\text { Ramt Hovav, Deserto } \\
\text { de Negev, Israel }\end{array}$ & $\begin{array}{l}\text { Ramalina } \\
\text { maciformis }\end{array}$ & Líquen & rochas & $\begin{array}{l}\text { Elementos químicos: B, } \\
\text { Cd, Co, Cu, Fe, K, Mg, } \\
\text { Mn, Na, Ni, P, Pb, Sr, } \\
\text { Zn }\end{array}$ & industrial & ativa, campo & $\sim 4$ meses & \begin{tabular}{|c|} 
produção de etileno (fito-hormônio); \\
atividade fotossintética II; integridaded \\
de membranas celulares; concentração \\
elementos químicos
\end{tabular} & reação & \\
\hline GARTY, J. et al., 2003. & Hadera, Israel & Ramalina lacera & Líquen & epífita & $\begin{array}{l}\text { Metais: Al, Ba, Ca, Cr, } \\
\text { Cu, Fe, K, Mg, Mn, Na, } \\
\text { Pb, S, Sr, V, Zn }\end{array}$ & termoelétrica a carvão & ativa, campo & 6 meses & \begin{tabular}{|c|} 
concentrações dos elementos nas \\
amostras de líquene expostas; \\
parâmetros fisiológicos: fluorescência \\
da clorofila; sistema fotossintético II; \\
condutividade elétrica (membranas \\
celulares), produção de etileno \\
\end{tabular} & $\begin{array}{l}\text { acumulação e } \\
\text { reação }\end{array}$ & \\
\hline
\end{tabular}




\begin{tabular}{|c|c|c|c|c|c|c|c|c|c|c|c|}
\hline Referência & $\begin{array}{l}\text { Local do estudo } \\
\text { Cidade e País }\end{array}$ & Espécie & $\begin{array}{c}\text { Divisião / Ordem } \\
\text { Botânica }\end{array}$ & Hábito & Poluentes & Fonte de poluição & $\begin{array}{l}\text { Exposição da planta } \\
\text { ativa/passiva; } \\
\text { laboratório/campo }\end{array}$ & $\begin{array}{l}\text { Tempo de } \\
\text { exposição }\end{array}$ & Parâmetros analisados & $\begin{array}{c}\text { Tipo de } \\
\text { bioindicador } \\
\text { reação/ } \\
\text { acumulação }\end{array}$ & Observações \\
\hline $\begin{array}{l}\text { GEEBELEN, W.; } \\
\text { HOFFMANN, M., } 2001 .\end{array}$ & Flanders, Bélgica & várias espécies & Musgos e Líquens & epífitas & SO2 & atividades urbanas & passiva & $\begin{array}{c}\text { não } \\
\text { especificado }\end{array}$ & IAP - índice de pureza atmosférica & reação & $\begin{array}{l}\text { IAP baseado no } \\
\text { número de espécies; } \\
\text { espécies } \\
\text { companheiras; } \\
\text { abundância e } \\
\text { cobertura } \\
\end{array}$ \\
\hline $\begin{array}{l}\text { GENONI, P.; PARCO, V.; } \\
\text { SANTAGOSTINO, A., } 2000\end{array}$ & $\begin{array}{l}\text { Província de Milão, } \\
\text { Norte da Itália }\end{array}$ & $\begin{array}{l}\text { Hypnum } \\
\text { cupressiforme }\end{array}$ & Briófita, musgo & & elementos-traço & Termoelétrica & passiva & 2 meses & $\begin{array}{l}\text { concentração dos elementos nas } \\
\text { amostras do musgos e concentração } \\
\text { de metais no solo }\end{array}$ & acumulação & $\begin{array}{c}\text { Bioacumulação - } \\
\text { diferençą entre } \\
\text { concentração metais } \\
\text { no musgo e } \\
\text { concentração metais } \\
\text { no solo } \\
\end{array}$ \\
\hline $\begin{array}{l}\text { GEOFF, N.; FRANCES, D., } \\
2001\end{array}$ & $\begin{array}{l}\text { Slatina e Isalnita, } \\
\text { Romênia }\end{array}$ & $\begin{array}{l}\text { graminea (não } \\
\text { especificada) }\end{array}$ & Angiosperma & herbácea & $\mathrm{F}$ & \begin{tabular}{|c|}
$\begin{array}{c}\text { industrial (metalúrgia } \\
\text { do alumínio); } \\
\text { termoelétrica a carvão }\end{array}$ \\
\end{tabular} & passiva & & $\begin{array}{l}\text { concentração de F em amostras de } \\
\text { grama e solo }\end{array}$ & acumulação & \\
\hline GERDOL, R. et al., 2002. & $\begin{array}{l}\text { Ferrara, Itália (urbano } \\
\text { e rural) }\end{array}$ & Tortula muralis & Briófita, musgo & $\begin{array}{l}\text { pedras e } \\
\text { paredes }\end{array}$ & PAHs; metais & $\begin{array}{c}\text { Queima de } \\
\text { combustívbel fossil; } \\
\text { TDL }\end{array}$ & passiva & 10 dias & $\begin{array}{l}\text { análises químicas: concentração } \\
\text { PAHs e variação percentual entre os } \\
\text { PAHs; concentração metais e \%; } \\
\text { isótopos estáveis de N } \\
\end{array}$ & acumulação & $\begin{array}{l}\text { TDL - transporte de } \\
\text { poluentes de longas } \\
\text { distâncias }\end{array}$ \\
\hline $\begin{array}{c}\text { GIORDANI, P.; } \\
\text { BRUNIALTI, G.; ALLETEO, } \\
\text { D., 2002. }\end{array}$ & Ligúria, Itália & & Líquen & epífita & SO2 e NOx & $\begin{array}{c}\text { industrial, } \\
\text { termoelétrica }\end{array}$ & passiva & $\begin{array}{c}\text { não } \\
\text { especificado }\end{array}$ & Biodiversidade de líquens epífitas & reação & \\
\hline GODZIK, B., 1997. & $\begin{array}{l}\text { Província de Krakóv, } \\
\text { Polônia }\end{array}$ & $\begin{array}{c}\text { Nicotiana tabacum } \\
\text { Bel-W3 (sensível) e } \\
\text { Bel-B (resistente) } \\
\end{array}$ & Angiosperma & arbustiva & $\mathrm{O} 3$ & $\begin{array}{c}\text { industrial } \\
\text { (metalúrgica, } \\
\text { cimento), termo- } \\
\text { elétrica, calefação }\end{array}$ & ativa, campo & 18 e 26 dias & $\begin{array}{l}\text { concentração de O3 na troposfera; } \\
\text { injúrias foliares }\end{array}$ & reação & \\
\hline $\begin{array}{l}\text { GOMBERT, S.; ASTA, J.; } \\
\text { SEAWARD, M.R.D., } 2003 .\end{array}$ & Grenoble, França & $\begin{array}{l}\text { Physcia adscendens } \\
\text { Hypogymnia } \\
\text { physodes } \\
\end{array}$ & Líquen & epífita & NOx & \begin{tabular}{|c|}
$\begin{array}{c}\text { tráfego de veículos em } \\
\text { ambiente urbano }\end{array}$ \\
\end{tabular} & passiva & $\begin{array}{c}\text { não } \\
\text { especificado }\end{array}$ & \begin{tabular}{|c|} 
concentração de N nas amostras de \\
líquen e mapeamento da área urbana; \\
índice de tráfego \\
\end{tabular} & acumulação & \\
\hline $\begin{array}{l}\text { GONZALEZ, C.M.; } \\
\text { PIGNATA, M.L., } 1997 .\end{array}$ & Córdoba, Argentina & $\begin{array}{l}\text { Punctella } \\
\text { subrudecta }\end{array}$ & Líquen & epífita & não especificado & $\begin{array}{l}\text { veículo, usina } \\
\text { termoelétrica, } \\
\text { industrial }\end{array}$ & ativa, campo & & \begin{tabular}{|c|} 
concentração de clorofila e faeofitina; \\
conc. proteínas solúveis; S; produtos \\
da oxidação; índice de poluição
\end{tabular} & reação & \\
\hline $\begin{array}{l}\text { GONZÁLEZ, C.M.; } \\
\text { PIGNATA. M.L., } 2000\end{array}$ & Córdoba, Argentina & $\begin{array}{l}\text { Canomaculina } \\
\text { pilosa }\end{array}$ & Líquen & & não especificado & $\begin{array}{l}\text { veículos, usina } \\
\text { termoelétrica, } \\
\text { industrial } \\
\end{array}$ & ativa, campo & & $\begin{array}{l}\text { clorofila, faeofitina, produtos da } \\
\text { peroxidação, proteínas solúveis, S }\end{array}$ & reação & \\
\hline GRASSO, M.F. et al., 1999. & $\begin{array}{l}\text { Monte Etna e Illha } \\
\text { Vulcano, Itália }\end{array}$ & $\begin{array}{l}\text { Parmelia } \\
\text { conspersa; } \\
\text { Xanthoria } \\
\text { parietina; } \\
\text { Stereocaulon } \\
\text { vesuvianum }\end{array}$ & Líquen & $\begin{array}{l}\text { troncos e } \\
\text { rochas }\end{array}$ & $\begin{array}{l}\text { elementos químicos } \\
\text { inorgânicos }\end{array}$ & emissões vulcânicas & passiva & $\begin{array}{c}\text { não } \\
\text { especificado }\end{array}$ & \begin{tabular}{|c|} 
concentração dos elementos químicos \\
considerados nas amostras de líquens
\end{tabular} & acumulação & \\
\hline GRATANI, L. et al., 2000 & Roma, Itália & Quercus ilex & Angiosperma & arbórea & $\begin{array}{l}\text { Metais: Na, Sr, Mn, Cu, } \\
\text { Zn, Pb, K, Mg, Ca, Fe, } \\
\text { B e Al }\end{array}$ & tráfego de veículos & passiva & 1 e 2 anos & \begin{tabular}{|c|} 
concentração dos poluentes em folhas \\
de 1 anc; aspectos anatômicos das \\
folhas; produção de brotos; \\
concentração de clorofila e \\
carotenóides; atividade fotossintética \\
\end{tabular} & reação & \\
\hline $\begin{array}{c}\text { GRODZINSKA, K.; } \\
\text { SZAREK-LUKASZEWSKA, } \\
\text { G., } 2001 . \\
\end{array}$ & Polônia & $\begin{array}{l}\text { Pleurozium } \\
\text { schreberi }\end{array}$ & Briófita, musgos & & $\mathrm{Pb}$ & industrial & passiva & 20 anos & \begin{tabular}{|c|} 
concentração de $\mathrm{Pb}$ em amostras de \\
musgos de 12 parques nacionais, de \\
1975 a 1995 \\
\end{tabular} & acumulação & \\
\hline $\begin{array}{l}\text { GRODZINSKA, K.; } \\
\text { SZAREK-LUKASZEWSKA, } \\
\text { G., } 2001 .\end{array}$ & Polônia & $\begin{array}{l}\text { Pleurozium } \\
\text { schreberi }\end{array}$ & Briófita, musgos & & Metais & industrial & passiva & 5 anos & $\begin{array}{l}\text { concentracãão de metais pesados em } \\
\text { amostras de musgos coletados em } \\
\text { todo o país: Programa "Atmospheric } \\
\text { Heavey metal Deposition in Europe" }\end{array}$ & acumulação & \\
\hline
\end{tabular}




\begin{tabular}{|c|c|c|c|c|c|c|c|c|c|c|c|}
\hline Referência & $\begin{array}{l}\text { Local do estudo } \\
\text { Cidade e País }\end{array}$ & Espécie & $\begin{array}{c}\text { Divisão / Ordem } \\
\text { Botânica }\end{array}$ & Hábito & Poluentes & Fonte de poluição & $\begin{array}{c}\text { Exposicicão da planta } \\
\text { ativa/passiva; } \\
\text { laboratório/campo }\end{array}$ & $\begin{array}{l}\text { Tempo de } \\
\text { exposição }\end{array}$ & Parâmetros analisados & $\begin{array}{c}\text { Tipo de } \\
\text { bioindicador } \\
\text { reação/ } \\
\text { acumulação }\end{array}$ & Observações \\
\hline $\begin{array}{c}\text { GRODZINSKA, K.; } \\
\text { SZAREK-LUKASZEWSKA, } \\
\text { G., } 2001 .\end{array}$ & $\begin{array}{l}\text { Polônia (Silesia - } \\
\text { Krakóv) }\end{array}$ & $\begin{array}{l}\text { Pleurozium } \\
\text { schreberi }\end{array}$ & Briófita, musgos & & Metais & industrial & passiva & $\begin{array}{c}\text { não } \\
\text { especificado }\end{array}$ & $\begin{array}{l}\text { concentração de metais pesados em } \\
\text { amostras de musgos coletados }\end{array}$ & acumulação & \\
\hline $\begin{array}{l}\text { GRODZINSKA, K.; } \\
\text { SZAREK-LUKASZEWSKA, } \\
\text { G., 2001. } \\
\end{array}$ & Polônia & $\begin{array}{l}\text { Pleurozium } \\
\text { schreberi }\end{array}$ & Briófita, musgos & & $\begin{array}{c}\text { Metais: } \mathrm{Cd}, \mathrm{Cu}, \mathrm{Fe}, \mathrm{Pb} \\
\text { e Zn }\end{array}$ & metalúrgicas & passiva & 20 anos & $\begin{array}{l}\text { concentração de metais pesados em } \\
\text { amostras de musgos coletados }\end{array}$ & acumulação & \\
\hline $\begin{array}{l}\text { GRODZINSKA-JURCZAK, } \\
\text { M.; SZAREK- } \\
\text { LUKASZEWSKA, G., } 1999\end{array}$ & Polônia & $\begin{array}{l}\text { Pinus sylvestris; } \\
\text { Picea abies }\end{array}$ & Coniferofita & arbórea & SO2, NO2 & industrial, tráfego & passiva & 1 e 2 anos & \begin{tabular}{|c|} 
concentração SO2 e NO2 no ar; \\
concentração de S e N em acículas de \\
plantas expostas; degradaçacão da cera \\
epicuticular \\
\end{tabular} & $\begin{array}{l}\text { acumulação } \\
\text { (N, S); } \\
\text { reaçâo (cera) }\end{array}$ & \\
\hline $\begin{array}{l}\text { GUIMARÃES, E.T. et al., } \\
2000\end{array}$ & São Paulo, Brasil & $\begin{array}{l}\text { Tradescantia } \\
\text { pallida cv. } \\
\text { purpurea }\end{array}$ & Angiosperma & herbácea & $\begin{array}{l}\text { mistura complexa de } \\
\text { gases }\end{array}$ & tráfego de veículos & passiva e ativa, campo & 4 meses & $\begin{array}{c}\text { Genotoxcidade: } \mathrm{n}^{\circ} \text { de micronúcleos } \\
\text { formados durante divisão meiótica de } \\
\text { células (Trad- MCN) }\end{array}$ & reação & \begin{tabular}{c|} 
monitoramento da \\
qualidade do ar nas \\
áreas sobre influência \\
de tráfego acentuado \\
de veículos
\end{tabular} \\
\hline $\begin{array}{l}\text { HALLERAKER, J.H. et al., } \\
1998 .\end{array}$ & Ártico Europeu & $\begin{array}{l}\text { Hylocomium } \\
\text { splendens; } \\
\text { Pleurozium } \\
\text { schreberi }\end{array}$ & Briófita, musgo & $\begin{array}{c}\text { formação em } \\
\text { tapete no solo }\end{array}$ & $\begin{array}{l}\text { elementos químicos } \\
\text { inorgânicos }\end{array}$ & $\begin{array}{l}\text { industrial de fontes } \\
\text { distantes }\end{array}$ & passiva & $\begin{array}{c}\text { não } \\
\text { especificado }\end{array}$ & \begin{tabular}{|} 
concentração dos elementos químicos \\
considerados nas amostras de musgos
\end{tabular} & acumulação & \\
\hline $\begin{array}{l}\text { HEAGLE, A.S.; } \\
\text { STEFANSKI, L.A., } 2000\end{array}$ & $\begin{array}{l}\text { Estados Unidos da } \\
\text { América ( } 8 \\
\text { localidades) }\end{array}$ & \begin{tabular}{|c|}
$\begin{array}{c}\text { Trifolium repens } \\
\text { (clones resistentes e } \\
\text { sensiveis) }\end{array}$ \\
\end{tabular} & Angiosperma & herbácea & $\mathrm{O} 3$ & não especificado & ativa, campo & 2 anos & produção de biomassa & reação & \begin{tabular}{|c|} 
Registros de conc. \\
ambientais O3 e efeito \\
cumulativo nas \\
plantas \\
\end{tabular} \\
\hline HIATT, M.H., 1999 & Las Vegas, USA & $\begin{array}{c}\text { Pihosporum toriba; } \\
\text { Rosmarinus } \\
\text { officinalis } \\
\text { prostrattus; } \\
\text { Juniperus sabina } \\
\text { tamariscifolia } \\
\end{array}$ & $\begin{array}{l}\text { Angiosperma } \\
\text { Coniferofita }\end{array}$ & arbustiva & VOCs & não especificado & passiva & $\begin{array}{c}\text { não } \\
\text { especificado }\end{array}$ & $\begin{array}{l}\text { concentração de VOCs nas folhas das } \\
\text { espécies selecionadas e concentração } \\
\text { de VOCs no ar }\end{array}$ & acumulação & \\
\hline $\begin{array}{l}\text { HIRANO, T.; MORIMOTO, } \\
\text { K., } 1999\end{array}$ & $\begin{array}{l}\text { Hamadera, Osaka, } \\
\text { Keino-Matsubara, } \\
\text { Japão }\end{array}$ & Pinus thumbergii & Coniferofita & arbórea & $\mathrm{SO} 2$ & industrial & passiva & $\sim 80$ anos & $\begin{array}{l}\text { Variações de espessura nos anéis de } \\
\text { crescimento }\end{array}$ & reação & \\
\hline HOLOUBEK, I. et al., 2000. & República Tcheca & $\begin{array}{c}\text { Hypnum } \\
\text { cupressiforme }\end{array}$ & Briófita, musgo & & $\begin{array}{c}\text { PAHs, pesticidas } \\
\text { organoclorados e PCBs }\end{array}$ & industrial & passiva & 3 anos & $\begin{array}{l}\text { concentração dos poluentes em } \\
\text { amostras de musgos }\end{array}$ & acumulação & \\
\hline HOLOUBEK, I. et al., 2000. & República Tcheca & Pinus sylvestris & Coniferofita & arbórea & \begin{tabular}{c|} 
PAHs, pesticidas \\
organoclorados e PCBs
\end{tabular} & industrial & passiva & 3 anos & $\begin{array}{c}\text { concentração dos poluentes em } \\
\text { acículas de } 3 \text { anos }\end{array}$ & acumulação & \\
\hline $\begin{array}{l}\text { JALKANEN LIISA et al, } \\
2000\end{array}$ & Finlândia & $\begin{array}{l}\text { Pleurozium } \\
\text { schreberi; } \\
\text { Hylocomium } \\
\text { splendens }\end{array}$ & Briófita, Musgo & & material particulado & $\begin{array}{l}\text { usina termoelétrica } \\
\text { (xisto) e fábrica de } \\
\text { cimento da Estônia } \\
\text { (TLD) }\end{array}$ & passiva & $\begin{array}{c}\text { não } \\
\text { especificado }\end{array}$ & $\begin{array}{c}\text { concentrações de MP no ar }(<2,5 \\
\text { microm. e 2,5 - } 15 \text { microm.); } \\
\text { concentração química do MP (31 } \\
\text { elementos); concentração de } \\
\text { elementos quumicos nas amostras de } \\
\text { musgo expostas } \\
\end{array}$ & acumulação & $\begin{array}{c}\text { TLD - Transporte de } \\
\text { poluentes de longas } \\
\text { distâncias }\end{array}$ \\
\hline $\begin{array}{l}\text { JALKANEN LIISA et al, } \\
2000\end{array}$ & Finlândia & & Líquen & & material particulado & $\begin{array}{l}\text { usina termoelétrica } \\
\text { (xisto) e fábrica de } \\
\text { cimento da Estônia } \\
\text { (TLD) }\end{array}$ & passiva & $\begin{array}{c}\text { não } \\
\text { especificado }\end{array}$ & $\begin{array}{l}\text { crescimento; presença e ausência de } \\
12 \text { espécies de líquens em área de } \\
2.500 \mathrm{Km} 2 \text {, nas vizinhanças das } \\
\text { fontes }\end{array}$ & reação & \\
\hline $\begin{array}{c}\text { JEZIERSKI, A.; BYLINSKA, } \\
\text { E.; SEAWARD, M.R.D. , } \\
1999\end{array}$ & Lower Silesia, Polônia & $\begin{array}{l}\text { Hypogymnia } \\
\text { physodes }\end{array}$ & Líquen & epífita & SO2 & não especificado & passiva & $\begin{array}{c}\text { não } \\
\text { especificado }\end{array}$ & \begin{tabular}{|c|} 
radicais livres, Fe III, Mn II: \\
concentrações nas amostras coletadas
\end{tabular} & reação & \\
\hline $\begin{array}{c}\text { JEZIERSKI, A.; BYLINSKA, } \\
\text { E.; SEAWARD, M.R.D., } \\
1999\end{array}$ & Lower Silesia, Polônia & Lasallia pustulata & Líquen & pedras & SO2 & não especificado & passiva & $\begin{array}{c}\text { não } \\
\text { especificado }\end{array}$ & \begin{tabular}{|c|} 
radicais livres, Fe III, Mn II: \\
concentraçōes nas amostras coletadas
\end{tabular} & reação & \\
\hline
\end{tabular}




\begin{tabular}{|c|c|c|c|c|c|c|c|c|c|c|c|}
\hline Referência & $\begin{array}{l}\text { Local do estudo } \\
\text { Cidade e País }\end{array}$ & Espécie & $\begin{array}{c}\text { Divisão / Ordem } \\
\text { Botânica }\end{array}$ & Hábito & Poluentes & Fonte de poluição & $\begin{array}{c}\text { Exposição da planta } \\
\text { ativa/passiva; } \\
\text { laboratório/campo }\end{array}$ & $\begin{array}{l}\text { Tempo de } \\
\text { exposição }\end{array}$ & Parâmetros analisados & $\begin{array}{c}\text { Tipo de } \\
\text { bioindicador } \\
\text { reação/ } \\
\text { acumulação }\end{array}$ & Observações \\
\hline $\begin{array}{c}\text { JEZIERSKI, A.; BYLINSKA, } \\
\text { E.; SEAWARD, M.R.D., } \\
1999\end{array}$ & Lower Silesia, Polônia & Lasallia pustulata & Líquen & pedras & NO2 & não especificado & ativa, laboratório & $\begin{array}{c}\text { não } \\
\text { especificado }\end{array}$ & $\begin{array}{l}\text { concentração de radicais livres nas } \\
\text { amostras coletadas }\end{array}$ & reação & \\
\hline $\begin{array}{c}\text { JEZIERSKI, A.; BYLINSKA, } \\
\text { E.; SEAWARD, M.R.D., } \\
1999\end{array}$ & Lower Silesia, Polônia & Umbilicaria sp & Líquen & pedras & NO2 & & & & $\begin{array}{l}\text { concentração de radicais livres nas } \\
\text { amostras coletadas }\end{array}$ & reação & \\
\hline KANOUN, M. et al., 2001 & Montardon, França & $\begin{array}{c}\text { Phaseolus vulgaris } \\
\text { cv. Nerina }\end{array}$ & Angiosperma & herbácea & Ozônio (O3) & $\begin{array}{l}\text { induzido por } \\
\text { fumigação }\end{array}$ & ativa, campo & $\begin{array}{c}6,13,20 \text { e } 27 \\
\text { dias }\end{array}$ & $\begin{array}{c}\text { injúrias visíveis em folhas, compostos } \\
\text { fenólicos, produção de biomassa }\end{array}$ & reação & \\
\hline KEANE, B. et al., 2001. & $\begin{array}{l}\text { Estados Unidos } \\
\text { (29 localidades) }\end{array}$ & $\begin{array}{c}\text { Taraxacum } \\
\text { officinale }\end{array}$ & Angiosperma & herbácea & MP-10 (metais) & $\begin{array}{c}\text { industrial e atividades } \\
\text { urbanas }\end{array}$ & passiva & $\begin{array}{c}\text { não } \\
\text { especificado }\end{array}$ & \begin{tabular}{|c|} 
concentração de metais (Cd, Cr, Cu, \\
Fe, Mn, Ni, Pb, Zn) em folhas da \\
planta exposta e no solo \\
\end{tabular} & acumulação & \\
\hline $\begin{array}{l}\text { KEYMEULEN, R. et al., } \\
2001 .\end{array}$ & $\begin{array}{l}\text { Bélgica, Hungria, } \\
\text { Lituânia }\end{array}$ & Pinus sylvestris & Coniferofita & arbórea & VOCs & $\begin{array}{l}\text { veículos, postos de } \\
\text { combustível }\end{array}$ & passiva & 1 ano & $\begin{array}{c}\text { concentração de BTXES nas acículas } \\
\text { e no ar atmosférico }\end{array}$ & acumulação & $\begin{array}{l}\text { BTEX - benzeno, } \\
\text { tolueno, etil-benzeno } \\
\text { e xileno }\end{array}$ \\
\hline $\begin{array}{l}\text { KLEIER, C.; } \\
\text { FARNSWORTH, B.; } \\
\text { WINNER, W., } 2001\end{array}$ & Estados Unidos & Raphanus sativus & Angiosperma & herbácea & $\mathrm{O} 3$ & fumigação, induzida & ativa, laboratório & 29 dias & $\begin{array}{l}\text { taxa fotossintética, biomassa foliar e } \\
\text { radicular, área foliar }\end{array}$ & reação & $\begin{array}{c}\text { Verificada a } \\
\text { interferência na } \\
\text { produção de } \\
\text { biomassa, pela ação } \\
\text { isolada e conjunta de } \\
\text { baixas temperaturas } \\
\text { na região da raiz e } \\
\text { presença de O3 }\end{array}$ \\
\hline KLUMPP, A. et al., 1998. & Cubatão, Brasil & $\begin{array}{c}\text { Tibouchina } \\
\text { pulchra; } \\
\text { Miconia pyrifolia }\end{array}$ & Angiosperma & arbóreas & $\begin{array}{l}\text { mistura complexa de } \\
\text { poluentes }\end{array}$ & industrial & passiva & $\begin{array}{c}\text { não } \\
\text { especificado }\end{array}$ & $\begin{array}{l}\text { concentracacão foliar de fluoretos; } \\
\text { concentração foliar de N, S, Fe, Al, } \\
\text { Mn, Zn; compostos sulfídricos } \\
\text { solúveis em água; acído ascórbico e } \\
\text { atividade da peroxidase }\end{array}$ & acumulação & \\
\hline KLUMPP, A. et al., 1998. & Cubatão, Brasil & $\begin{array}{l}\text { Cecropia glaziovii; } \\
\text { Miconia pyrifolia }\end{array}$ & Angiosperma & arbóreas & $\begin{array}{l}\text { mistura complexa de } \\
\text { poluentes }\end{array}$ & industrial & passiva & $\begin{array}{c}\text { não } \\
\text { especificado }\end{array}$ & $\begin{array}{l}\text { concentração foliar de fluoretos; } \\
\text { concentraçâo foliar de N, , Fe, Al, } \\
\text { Mn, Zn,; compostos sulfídricos } \\
\text { solúveis em água; acído ascórbico e } \\
\text { atividade da peroxidase }\end{array}$ & não evidenciado & \\
\hline KLUMPP, A. et al., 1998. & Cubatão, Brasil & $\begin{array}{c}\text { Tibouchina } \\
\text { pulchra; } \\
\text { Psidium guayava }\end{array}$ & Angiosperma & arbóreas & $\begin{array}{l}\text { mistura complexa de } \\
\text { poluentes }\end{array}$ & industrial & ativa & 16 semanas & $\begin{array}{l}\text { concentração foliar de fluoretos; } \\
\text { concentraçấo foliar de N, , Fe, Al, } \\
\text { Mn, Zn,; compostos sulfídricos } \\
\text { solúveis em água; acído ascórbico e } \\
\text { atividade da peroxidase }\end{array}$ & acumulação & \\
\hline KLUMPP, A. et al., 1998. & Cubatão, Brasil & $\begin{array}{c}\text { Psidium } \\
\text { cattleyanum }\end{array}$ & Angiosperma & arbóreas & $\begin{array}{l}\text { mistura complexa de } \\
\text { poluentes }\end{array}$ & industrial & ativa & 16 semanas & $\begin{array}{l}\text { concentração foliar de fluoretos; } \\
\text { concentraçâo foliar de N, S, Fe, Al, } \\
\text { Mn, Zn; compostos sulfídricos } \\
\text { solúveis em água; acído ascórbico e } \\
\text { atividade da peroxidase }\end{array}$ & acumulação & \\
\hline KLUMPP, G. et al., 2000 & Cubatão, Brasil & $\begin{array}{l}\text { Tibouchina pulchra } \\
\text { Cogn. }\end{array}$ & Angiosperma & arbórea & $\begin{array}{l}\text { mistura complexa de } \\
\text { poluentes }\end{array}$ & industrial & ativa e passiva, campo & & $\begin{array}{l}\text { peroxidase, pH e poder tampão de } \\
\text { extratos de folhas, conc. ácido } \\
\text { ascórbico, compostos de tiol solúveis } \\
\text { em água, parte aérea/sistema radicular }\end{array}$ & reação & $\begin{array}{l}\text { A espécie pode ser } \\
\text { considerada como } \\
\text { tolerante à poluição } \\
\text { do ar, pela alta } \\
\text { capacidade de } \\
\text { sobrevivência em } \\
\text { locais poluídos } \\
\end{array}$ \\
\hline $\begin{array}{l}\text { KOPPER, B.J.; LINDROTH, } \\
\text { R.L.; NORDHEEIM, E.V., } \\
2001 .\end{array}$ & Rhinelander, EUA & Betula papyrifera & Angiosperma & arbórea & $\mathrm{CO} 2, \mathrm{O} 3$ & $\begin{array}{l}\text { induzida por } \\
\text { fumigação }\end{array}$ & ativa, campo & $\sim 1$ ano & & reação & \\
\hline $\begin{array}{l}\text { KRUPA, S.V.; LEGGE, } \\
\text { A.H.,1999 }\end{array}$ & Alberta, Canadá & $\begin{array}{l}\text { Amelanchier } \\
\text { alnifolia }\end{array}$ & Angiosperma & arbustiva & $\begin{array}{l}\text { SO2, NOx, } \\
\text { Hidrocarbonetos }\end{array}$ & $\begin{array}{l}\text { fontes fixas não } \\
\text { especificadas }\end{array}$ & ativa, campo & 3 anos & $\begin{array}{l}\text { injúrias foliares (cloroses e necroses) } \\
\text { nas plantas in isitu; dados } \\
\text { meteorológicos; concentraçoes de S } \\
\text { no solo; monitoramento da qualidade } \\
\text { do ar (SO2, NOx, O3, VOCs) }\end{array}$ & reação & \\
\hline
\end{tabular}




\begin{tabular}{|c|c|c|c|c|c|c|c|c|c|c|c|}
\hline Referência & $\begin{array}{l}\text { Local do estudo } \\
\text { Cidade e País }\end{array}$ & Espécie & $\begin{array}{c}\text { Divisão / Ordem } \\
\text { Botânica }\end{array}$ & Hábito & Poluentes & Fonte de poluição & $\begin{array}{c}\text { Exposicião da planta } \\
\text { ativa/passiva; } \\
\text { laboratório/campo }\end{array}$ & $\begin{array}{l}\text { Tempo de } \\
\text { exposição }\end{array}$ & Parâmetros analisados & $\begin{array}{c}\text { Tipo de } \\
\text { bioindicador } \\
\text { reação/ } \\
\text { acumulação }\end{array}$ & Observações \\
\hline KUBIZÑÁKOVÁ, J., 2001. & República Tcheca & Picea abies & Coniferofita & arbórea & $\mathrm{SO} 2$ & não especificado & passiva & $\begin{array}{c}\text { não } \\
\text { especificado }\end{array}$ & $\begin{array}{c}\text { deposicōes atmosféricas x circulação } \\
\text { de nutrientes - troca iônica }\end{array}$ & reação & $\begin{array}{c}\text { Espécie considerada } \\
\text { muito sensível à } \\
\text { poluição atmosférica } \\
\end{array}$ \\
\hline $\begin{array}{l}\text { KUEHLER, E.A.; } \\
\text { FLAGLER, R.B., } 1999 .\end{array}$ & Texas, USA & Pinus taeda & Coniferofita & arbórea & $\mathrm{O} 3$ & $\begin{array}{l}\text { induzida por } \\
\text { fumigação }\end{array}$ & ativa, campo & 5 meses & $\begin{array}{c}\text { condutância estomatale e fotossíntese } \\
\text { líquida; injúrias foliares; concentração } \\
\text { de pigmentos; concentração foliar de } \\
\text { N }\end{array}$ & reação & $\begin{array}{c}\text { Adição de O3 por } \\
\text { fumigação; plântulas } \\
\text { tratadas com anti- } \\
\text { oxidante a cada } 14 \\
\text { dias } \\
\end{array}$ \\
\hline $\begin{array}{l}\text { KURCZYNSKA, E.U. et al., } \\
1997 .\end{array}$ & Varsóvia, Polônia & Pinus sylvestris & Coniferofita & arbórea & $\begin{array}{l}\text { metais pesados, } \mathrm{NOx}, \\
\text { SO2 }\end{array}$ & $\begin{array}{c}\text { Industrial } \\
\text { (siderúrgica) e urbana }\end{array}$ & passiva & até 2 anos & \begin{tabular}{|c|} 
composição de metais e demais \\
elementos químicos em amostras de \\
acículas; análises anatômicas de caule
\end{tabular} & reação & \\
\hline $\begin{array}{l}\text { LIMA, J.S.; FERNANDES, } \\
\text { E. B.; FAWCETT, W. N., } \\
2000\end{array}$ & $\begin{array}{l}\text { Camaçari, Bahia, } \\
\text { Brasil }\end{array}$ & Mangifera indica & Angiosperma & arbórea & SO2, NOx, O3 & $\begin{array}{c}\text { Pólo Petroquímico de } \\
\text { Camaçari }\end{array}$ & passiva & $\begin{array}{c}\text { não } \\
\text { especificado }\end{array}$ & $\begin{array}{l}\text { concentração ácido ascórbico, área } \\
\text { foliar }\end{array}$ & reação & \begin{tabular}{|c|}
$\begin{array}{c}\text { espécie resistente aos } \\
\text { poluentes, apresentado } \\
\text { altas concentrações de } \\
\text { ácido ascorbico nas } \\
\text { folhas }\end{array}$ \\
\end{tabular} \\
\hline $\begin{array}{l}\text { LIMA, J.S.; FERNANDES, } \\
\text { E. B.; FAWCETT, W. N., } \\
2000\end{array}$ & $\begin{array}{l}\text { Camaçari, Bahia, } \\
\text { Brasil }\end{array}$ & Phaseolus vulgaris & Angiosperma & herbácea & SO2, NOx, O3 & $\begin{array}{c}\text { Pólo Petroquímico de } \\
\text { Camaçari }\end{array}$ & ativa, campo & 27 dias & $\begin{array}{l}\text { concentração ácido ascórbico, área } \\
\text { foliar }\end{array}$ & reação & \begin{tabular}{|c|} 
Espécie apresentou \\
redução da área foliar
\end{tabular} \\
\hline LODOVICI, M. et al., 1998 & Toscana, Itália & Laurus nobilis & Angiosperma & arbórea & PAHs & $\begin{array}{l}\text { ambiente urbano, } \\
\text { veículos, calefacăão, } \\
\text { industrial }\end{array}$ & passiva & & $\begin{array}{l}\text { concentração de PAHs nas folhas e no } \\
\text { ar atmosférico }\end{array}$ & acumulação & \\
\hline LOPPI S. et al., 2000 & Poggibonsi, Itália & Parmelia caperata & Líquen & epífita & $\begin{array}{l}\text { Metais: Al, Cd, Cr, Cu, } \\
\text { Fe, Hg, Pb e Zn }\end{array}$ & $\begin{array}{c}\text { incinerador de } \\
\text { resíduos sólidos } \\
\end{array}$ & passiva & 1 ano & $\begin{array}{c}\text { concentração dos elementos em } \\
\text { amostras de liquens nativos }\end{array}$ & acumulação & \\
\hline LOPPI, S. et al., 1998 & $\begin{array}{c}\text { Traveli, Radiocondili, } \\
\text { Itália Central } \\
\end{array}$ & Parmelia caperata & Líquen & epífita & S, As, B, Hg & Geo-termo elétrica & passiva & $\begin{array}{c}\text { não } \\
\text { especificado }\end{array}$ & $\begin{array}{l}\text { talos do líquen: concentração dos } \\
\text { elementos; IAP } \\
\end{array}$ & reação & $\begin{array}{c}\text { IAP - índice de pureza } \\
\text { atmosférica } \\
\end{array}$ \\
\hline LOPPI, S. et al., 1998 & $\begin{array}{c}\text { Traveli, Radiocondili, } \\
\text { Itália Central } \\
\end{array}$ & Quercus cerris & Angiosperma & arbórea & S, As, B, Hg & Geo-termo elétrica & passiva & $\begin{array}{c}\text { não } \\
\text { especificado }\end{array}$ & $\begin{array}{l}\text { folhas da espécie arbórea: } \\
\text { concentração dos elementos; IAP }\end{array}$ & reação & $\begin{array}{c}\text { IAP - índice de pureza } \\
\text { atmosférica } \\
\end{array}$ \\
\hline LOPPI, S., 2001. & Bagnore,Itália Central & Parmelia sp & Líquen & epífita & Mercúrio (Hg) & geo-termoelétrica & passiva & $\begin{array}{c}\text { não } \\
\text { especificado }\end{array}$ & $\begin{array}{c}\text { concentração de Hg e outros } \\
\text { elementos traço em amostras dos } \\
\text { liquens } \\
\end{array}$ & acumulação & \\
\hline LOPPI, S., 2001. & Bagnore,Itália Central & Xanthoria sp & Líquen & epífita & Mercúrio (Hg) & geo-termoelétrica & passiva & $\begin{array}{c}\text { não } \\
\text { especificado }\end{array}$ & $\begin{array}{l}\text { concentração de } \mathrm{Hg} \text { e outros } \\
\text { elementos traço em amostras dos } \\
\text { liquens }\end{array}$ & acumulação & \\
\hline LOPPI, S.; BONINI, I., 2000 & $\begin{array}{c}\text { Mt. Amiata, Toscana, } \\
\text { Itália }\end{array}$ & Parmelia sulcata & Líquen & epífita & $\begin{array}{l}\text { Metais: Al, As, B, Cd, } \\
\text { Cu, Fe, Hg, Mo, Pb, S, } \\
\text { Sb, Zn }\end{array}$ & $\begin{array}{l}\text { Fontes termais e } \\
\text { veículos }\end{array}$ & passiva & & $\begin{array}{l}\text { concentração dos elementos nas } \\
\text { amostras de líquen e musgo }\end{array}$ & acumulação & \\
\hline LOPPI, S.; BONINI, I., 2000 & $\begin{array}{c}\text { Mt. Amiata, Toscana, } \\
\text { Itália }\end{array}$ & $\begin{array}{c}\text { Hypnum } \\
\text { cupressiforme }\end{array}$ & Briófita, musgo & epífita & $\begin{array}{l}\text { Metais: Al, As, B, Cd, } \\
\text { Cu, Fe, Hg, Mo, Pb, S, } \\
\text { Sb, Zn }\end{array}$ & $\begin{array}{l}\text { Fontes termais e } \\
\text { veículos }\end{array}$ & passiva & & $\begin{array}{l}\text { concentração dos elementos nas } \\
\text { amostras de líquen e musgo }\end{array}$ & acumulação & \\
\hline $\begin{array}{l}\text { MADKOUR, S.A.; } \\
\text { LAURENCE, J.A., } 2002 .\end{array}$ & Estados Unidos & $\begin{array}{c}\text { Trifolium } \\
\text { alexandrinum } \\
\text { Medicago sativa }\end{array}$ & Angiosperma & & $\mathrm{O} 3$ & $\begin{array}{l}\text { induzida por } \\
\text { fumigação }\end{array}$ & ativa, laboratório & & $\begin{array}{c}\text { porcentagem área foliar com injúrias; } \\
\text { pigmentos: clorofila a e b e } \\
\text { carotenóides; trocas gasosas } \\
\end{array}$ & reação & \\
\hline $\begin{array}{l}\text { MADKOUR, S.A.; } \\
\text { LAURENCE, J.A., } 2002 .\end{array}$ & Estados Unidos & \begin{tabular}{|c|} 
Eruca sativa; \\
Corchorus olitorius \\
\end{tabular} & Angiosperma & & O3 & $\begin{array}{c}\text { induzida por } \\
\text { fumigação }\end{array}$ & ativa, laboratório & & $\begin{array}{c}\text { porcentagem área foliar com injúrias; } \\
\text { pigmentos: clorofila a e b e } \\
\text { carotenóides; trocas gasosas } \\
\end{array}$ & reação & \\
\hline MALM, O. et al., 1998. & $\begin{array}{c}\text { Alta Floresta, } \\
\text { Amazonas, Brasil } \\
\end{array}$ & $\begin{array}{l}\text { Tillandsia } \\
\text { usneoides }\end{array}$ & Angiosperma & $\begin{array}{c}\text { epífita } \\
\text { (bomélia) }\end{array}$ & $\mathrm{Hg}$ & $\begin{array}{c}\text { mineração e } \\
\text { manufatura do ouro }\end{array}$ & $\begin{array}{l}\text { ativa, campo; ativa, } \\
\text { laboratório }\end{array}$ & 15 e 45 dias & \begin{tabular}{|c|} 
concentração de Hg nas amostras de \\
plantas expostas \\
\end{tabular} & acumulação & \\
\hline MANKOVSKÁ, B., 1997. & Eslováquia & $\begin{array}{l}\text { Pleurozium } \\
\text { schreberi }\end{array}$ & Briófita, Musgo & epífita & Metais & industrial & passiva & & $\begin{array}{c}\text { concentração de metais nos tecidos da } \\
\text { planta }\end{array}$ & acumulação & \\
\hline MANKOVSKÁ, B., 1997. & Eslováquia & $\begin{array}{l}\text { Hylocomium } \\
\text { splendens }\end{array}$ & Briófita, Musgo & epífita & Metais & industrial & passiva & & $\begin{array}{c}\text { concentração de metais nos tecidos da } \\
\text { planta }\end{array}$ & acumulação & \\
\hline MANKOVSKÁ, B., 1997. & Eslováquia & $\begin{array}{l}\text { Dicranum } \\
\text { scoparium }\end{array}$ & Briófita, Musgo & epífita & Metais & industrial & passiva & & $\begin{array}{c}\text { concentração de metais nos tecidos da } \\
\text { planta }\end{array}$ & acumulação & \\
\hline
\end{tabular}




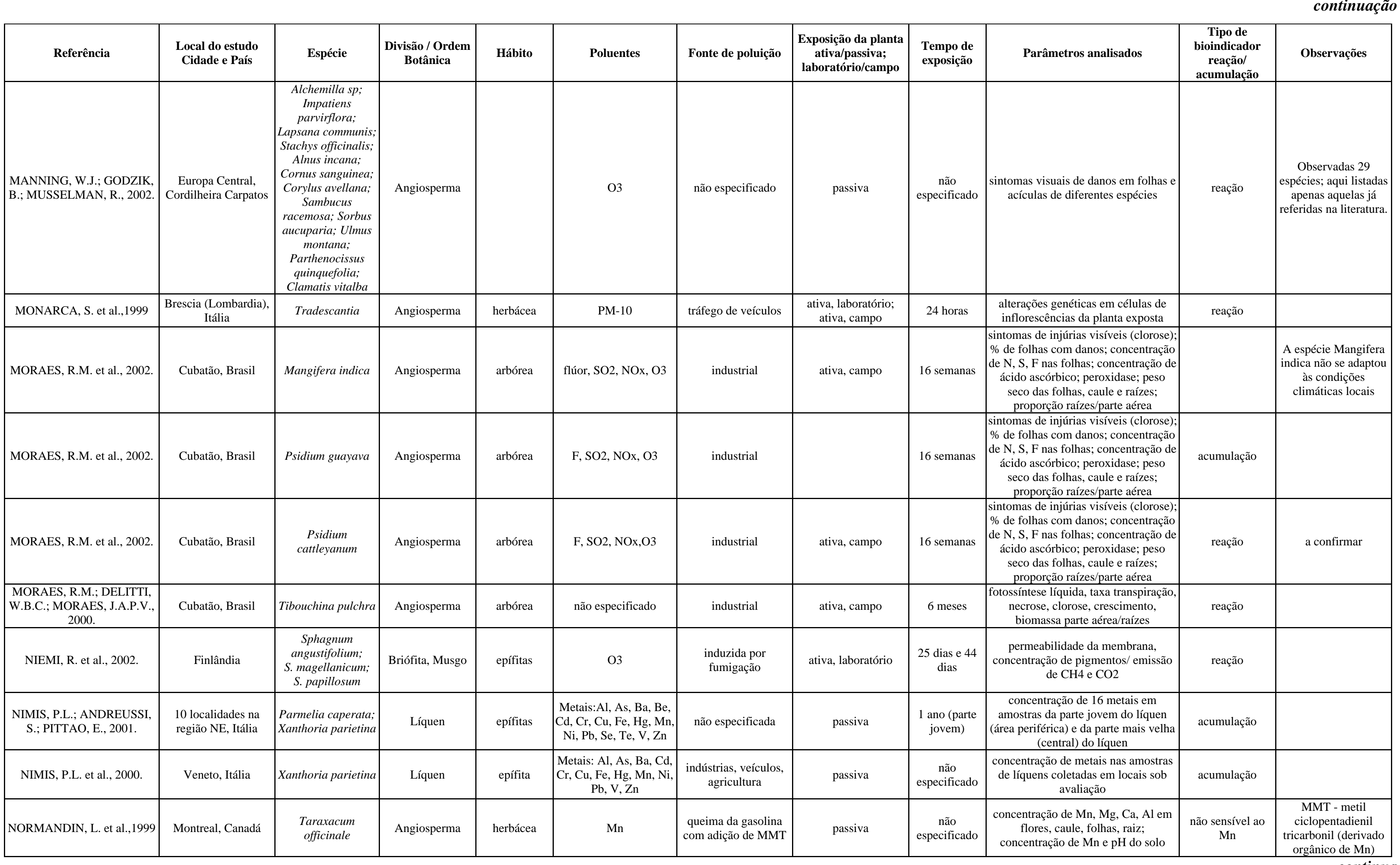




\begin{tabular}{|c|c|c|c|c|c|c|c|c|c|c|c|}
\hline Referência & $\begin{array}{l}\text { Local do estudo } \\
\text { Cidade e País }\end{array}$ & Espécie & $\begin{array}{c}\text { Divisão / Ordem } \\
\text { Botânica }\end{array}$ & Hábito & Poluentes & Fonte de poluição & $\begin{array}{l}\text { Exposisãão da planta } \\
\text { ativa/passiva; } \\
\text { laboratório/campo }\end{array}$ & $\begin{array}{l}\text { Tempo de } \\
\text { exposição }\end{array}$ & Parâmetros analisados & $\begin{array}{c}\text { Tipo de } \\
\text { bioindicador } \\
\text { reação/ } \\
\text { acumulação }\end{array}$ & Observações \\
\hline $\begin{array}{l}\text { ODUKOYA, O.O., } \\
\text { AROWOLO, T.A., } \\
\text { BAMGBOSE, O., } 2000\end{array}$ & $\begin{array}{l}\text { Abeokuta, Nigéria } \\
\text { (África) }\end{array}$ & \begin{tabular}{|c|} 
Ficus spp; Gmelina \\
arborea; Acacia \\
spp; Adansonia \\
spp; Spondias \\
monbin; Hura \\
cripitans \\
\end{tabular} & Angiosperma & arbóreas & $\mathrm{Pb}, \mathrm{Zn}, \mathrm{Cu}$ & Tráfego de veículos & passiva & $\begin{array}{c}\text { Não } \\
\text { especificado }\end{array}$ & $\begin{array}{l}\text { concentração dos elementos nas } \\
\text { amostras das cascas das árvores }\end{array}$ & acumulação & \\
\hline OMASA, K. et al., 2000 & Tókio, Japão & Populus nigra & Angiosperma & arbórea & VOCs e O3 & $\begin{array}{l}\text { induzida por } \\
\text { fumigação }\end{array}$ & ativa, estufa & $\begin{array}{c}\text { não } \\
\text { especificado }\end{array}$ & \begin{tabular}{|c|} 
absorbância foliar dos poluentes \\
orgânicos; absorcãao foliar do O3 \\
(p/efeito de comparaçao); capacidade \\
de decomposição cuticular do O3 \\
(estimativa)
\end{tabular} & acumulação & \\
\hline ORLANDI, M. et al., 2002. & Valdaosta, Itália & Larix decidua & Coniferofita & arbórea & $\begin{array}{c}\text { Metais: } \mathrm{Cd}, \mathrm{Cr}, \mathrm{Cu}, \mathrm{Ni}, \\
\mathrm{Pb}\end{array}$ & não especificada & passiva & 70 anos & $\begin{array}{c}\text { concentração de metais no xilema de } \\
\text { árvores expostas aos poluentes }\end{array}$ & acumulação & \\
\hline $\begin{array}{l}\text { PASQUALINI, V. et al., } \\
2003 .\end{array}$ & Provence, França & Pinus halepensis & Coniferofita & arbórea & $\begin{array}{l}\mathrm{NO}, \mathrm{NO} 2, \mathrm{NOx}, \mathrm{SO} 2 \\
\mathrm{O} 3\end{array}$ & industrial, tráfego & passiva & $\begin{array}{c}\text { não } \\
\text { especificado }\end{array}$ & \begin{tabular}{|c|} 
concentração de poluentes na \\
atmosfera e folhas; fenóis totais; fenol \\
simples
\end{tabular} & reação & \\
\hline PEÑUELAS, J. et al., 1999. & Catalonia, Espanha & $\begin{array}{c}\text { Nicotiana tabacum } \\
\text { (Bel-W3) }\end{array}$ & Angiosperma & arbustiva & O3 & ausente - zona rural & ativa, campo & 5 meses & $\begin{array}{c}\text { \% de área foliar com injúrias; } \\
\text { concentração de O3 na atmosfera; } \\
\text { dados meteorológicos }\end{array}$ & reação & \\
\hline PIGNATA, M.L. et al. , 2002. & Argentina & Tillandsia capillaris & Angiosperma & $\begin{array}{c}\text { epífita } \\
\text { (bromélia) }\end{array}$ & $\begin{array}{l}\text { Metais: } \mathrm{Co}, \mathrm{Cu}, \mathrm{Fe}, \mathrm{Ni}, \\
\mathrm{Mn}, \mathrm{Pb}, \mathrm{Zn}\end{array}$ & antrópicas diversas & passiva & $\begin{array}{c}\text { não } \\
\text { especificado }\end{array}$ & \begin{tabular}{|c|} 
concentração dos elementos químicos \\
em amostras das plantas; clorofila; \\
concentração de S; peroxidase
\end{tabular} & $\begin{array}{c}\text { reação e } \\
\text { acumulação }\end{array}$ & \\
\hline PIGNATA, M.L. et al., 1999. & Córdoba, Argentina & Mellia azedarach & Angiosperma & arbórea & não especificado & veículos, indústrias & passiva & $\begin{array}{c}\text { não } \\
\text { especificado }\end{array}$ & $\begin{array}{c}\text { área especifica da folha, pelo úmido x } \\
\text { peso seco, proténas solúveis, } \\
\text { concentração S, prod. peroxidação, } \\
\text { clorefina x faeofitiviva } \\
\end{array}$ & reação & $\begin{array}{l}\text { Espécie típica da } \\
\text { arborização urbana } \\
\text { local }\end{array}$ \\
\hline $\begin{array}{l}\text { POIKOLAINEN, J. et al., } \\
1998 .\end{array}$ & Finlândia & várias espécies & Líquen & epífita & compostos de S e N & não especificado & passiva & 10 anos & $\begin{array}{c}\text { mapeaamento das espécies de líquens; } \\
\text { abundância das espécies; deposição } \\
\text { de S (estimativa) nos locais de } \\
\text { amostragem; IAP }\end{array}$ & reação & $\begin{array}{c}\text { IAP- índice de pureza } \\
\text { atmosférica }\end{array}$ \\
\hline POMPÉIA, S.L., 1997. & Cubatão, (SP), Brasil & $\begin{array}{l}\text { Famílias } \\
\text { Myrtaceae, } \\
\text { Lauraceae, } \\
\text { Leguminosae }\end{array}$ & Angiosperma & $\begin{array}{l}\text { arbóreas do } \\
\text { dossel Mata } \\
\text { Atlântica }\end{array}$ & \begin{tabular}{|c|} 
Hidrocarbonetos, SO2, \\
NOx, fluoretos, MP, \\
NH3, O3, metais \\
pesados
\end{tabular} & industrial & passiva & $\begin{array}{c}\text { não } \\
\text { especificado }\end{array}$ & $\begin{array}{l}\text { composição e estrutura das } \\
\text { comunidades vegetais }\end{array}$ & sensível & \\
\hline POMPÉIA, S.L., 1997. & Cubatão, (SP), Brasil & $\begin{array}{l}\text { Famílias } \\
\text { Orchidaceae e } \\
\text { Bromeliaceae }\end{array}$ & Angiosperma & epífitas & $\begin{array}{l}\text { Hidrocarbonetos, SO2, } \\
\text { NOx, fluoretos, MP, } \\
\text { NH3, O3, metais } \\
\text { pesados }\end{array}$ & industrial & passiva & $\begin{array}{c}\text { não } \\
\text { especificado }\end{array}$ & $\begin{array}{l}\text { composição e estrutura das } \\
\text { comunidades vegetais }\end{array}$ & sensível & \\
\hline POMPÉIA, S.L., 1997. & Cubatão, (SP), Brasil & $\begin{array}{l}\text { Tibouchina spp; } \\
\text { Miconia } \\
\text { cinnamomifolia }\end{array}$ & Angiosperma & $\begin{array}{l}\text { arbóreas } \\
\text { pioneiras da } \\
\text { Mata } \\
\text { Atlântica }\end{array}$ & \begin{tabular}{|c|} 
Hidrocarbonetos, SO2, \\
NOx, fluoretos, MP, \\
NH3, O3, metais \\
pesados
\end{tabular} & industrial & passiva & $\begin{array}{c}\text { não } \\
\text { especificado }\end{array}$ & $\begin{array}{l}\text { composição e estrutura das } \\
\text { comunidades vegetais }\end{array}$ & resistentes & \\
\hline $\begin{array}{l}\text { RAUTIO, P.; HUTTUNEM, } \\
\text { S., } 2003 .\end{array}$ & Finlândia (Lapônia) & Pinus sylvestris & Coniferofita & arbórea & \begin{tabular}{|} 
Metais: Cu, Ni, Pb, Mg, \\
P, K, Mn, Zn; S e MP
\end{tabular} & Indústria metalúrgicas & passiva & até 2 anos & $\begin{array}{l}\text { concentração de S e metais em } \\
\text { acículas e no solo do local de coleta } \\
\text { das amostras }\end{array}$ & acumulação & \begin{tabular}{|c|} 
Amostras coletadas \\
em árvores de 30 a 50 \\
anos, acículas de 1 e 2 \\
anos \\
\end{tabular} \\
\hline $\begin{array}{l}\text { RIBAS, A.; PEÑUELAS, J., } \\
2003 .\end{array}$ & $\begin{array}{l}\text { Catalonia (rural), } \\
\text { Espanha }\end{array}$ & $\begin{array}{l}\text { Nicotiana tabacum } \\
\text { cultivar Bel - W3 }\end{array}$ & Angiosperma & arbustiva & Ozônio (O3) & não especificado & ativa, campo & $\begin{array}{c}\text { não } \\
\text { especificado }\end{array}$ & $\begin{array}{l}\text { danos visuais nas folhas (\% de área } \\
\text { danificada) }\end{array}$ & reação & \begin{tabular}{|c|} 
monitoramento \\
convencional da \\
qualidade do ar; dados \\
meteorológicos \\
\end{tabular} \\
\hline $\begin{array}{c}\text { RIGA-KARANDINOS, A. } \\
\text { N.; KARANDINOS, M. G., } \\
1998 .\end{array}$ & Megalópoles, Grécia & $\mid \begin{array}{c}\text { Anaptychia ciliares; } \\
\text { Lobaria } \\
\text { pulmonaria; } \\
\text { Ramalina farinacea }\end{array}$ & Líquen & & $\begin{array}{c}\text { Metais: } \mathrm{Ca}, \mathrm{Cd}, \mathrm{Cu}, \mathrm{Fe}, \\
\text { Mn, Pb e Zn; } \mathrm{S} \text { total }\end{array}$ & termoelétrica a carvão & passiva & $\begin{array}{c}\text { não } \\
\text { especificado }\end{array}$ & $\begin{array}{c}\text { concentração dos metais e S nas } \\
\text { amostras de líquens coletados; } \\
\text { parâmetros bioquímicos: pH dos } \\
\text { tecidos, clorofila / faeoofitiva, } \\
\text { proteínas totais, reduçâao de açucares }\end{array}$ & $\begin{array}{l}\text { acumulacãão e } \\
\text { reaçâo }\end{array}$ & \\
\hline
\end{tabular}




\begin{tabular}{|c|c|c|c|c|c|c|c|c|c|c|c|}
\hline Referência & $\begin{array}{l}\text { Local do estudo } \\
\text { Cidade e País }\end{array}$ & Espécie & $\begin{array}{c}\text { Divisão / Ordem } \\
\text { Botânica }\end{array}$ & Hábito & Poluentes & Fonte de poluição & $\begin{array}{c}\text { Exposição da planta } \\
\text { ativa/passiva; } \\
\text { laboratório/campo }\end{array}$ & $\begin{array}{l}\text { Tempo de } \\
\text { exposição }\end{array}$ & Parâmetros analisados & $\begin{array}{c}\text { Tipo de } \\
\text { bioindicador } \\
\text { reação/ } \\
\text { acumulação }\end{array}$ & Observações \\
\hline $\begin{array}{l}\text { RIGET, F.; ASMUND, G.; } \\
\text { AASTRUP, P., 2000. }\end{array}$ & Groelândia & Cetraria nivalis & Líquen & & \begin{tabular}{|c} 
Metais: $\mathrm{Pb}, \mathrm{Cd}, \mathrm{Hg}, \mathrm{Zn}$, \\
$\mathrm{Cu}, \mathrm{Cr}, \mathrm{Ni}, \mathrm{As}, \mathrm{V}, \mathrm{Al}$, \\
$\mathrm{Fe}$
\end{tabular} & $\begin{array}{l}\text { solo e transporte de } \\
\text { fontes distantes }\end{array}$ & passiva & $\begin{array}{c}\text { não } \\
\text { especificado }\end{array}$ & $\begin{array}{c}\text { concentração dos elementos químicos } \\
\text { considerados no solo e em amostras } \\
\text { de líquens }\end{array}$ & $\begin{array}{l}\text { acumulação } \\
\text { (Líquen) }\end{array}$ & \\
\hline $\begin{array}{l}\text { RIGET, F.; ASMUND, G.; } \\
\text { AASTRUP, P., } 2000 .\end{array}$ & Groelândia & $\begin{array}{l}\text { Rhacomitrium } \\
\text { lanuginosum }\end{array}$ & Musgo & & \begin{tabular}{|} 
Metais: Pb, Cd, Hg, Zn, \\
Cu, Cr, Ni, As, V, Al, \\
Fe
\end{tabular} & $\begin{array}{l}\text { solo e transporte de } \\
\text { fontes distantes }\end{array}$ & passiva & $\begin{array}{c}\text { não } \\
\text { especificado }\end{array}$ & \begin{tabular}{|c|}
$\begin{array}{c}\text { concentração dos elementos químicos } \\
\text { considerados no solo e em amostras } \\
\text { de musgos }\end{array}$ \\
\end{tabular} & acumulação & \\
\hline $\begin{array}{l}\text { ROSMAN, K. J. R et al., } \\
1998 .\end{array}$ & Noruega & $\begin{array}{l}\text { Hylocomium } \\
\text { splendens }\end{array}$ & Briófita, musgo & & $\mathrm{Pb}$ & não especificada & passiva & 3 anos & $\begin{array}{l}\text { composição isotópica do Pb em } \\
\text { amostras de musgos }\end{array}$ & acumulação & \begin{tabular}{|c} 
coletadas amostras em \\
6 pontos do país em: \\
1977, 1990, 1995
\end{tabular} \\
\hline ROSSBACH, M. et al., 1999 & \begin{tabular}{|c} 
Sibéria, Canadá, \\
Sirilanka, Alemanha
\end{tabular} & Usnea spp. & Líquen & epífita & não especificado & $\begin{array}{c}\text { transporte de } \\
\text { poluentes de longas } \\
\text { distâncias }\end{array}$ & passiva & $\begin{array}{c}\text { não } \\
\text { especificado }\end{array}$ & $\begin{array}{c}\text { concentração de } 31 \text { elementos } \\
\text { químicos }\end{array}$ & acumulação & \\
\hline $\begin{array}{c}\text { SAITANIS, C.J.; } \\
\text { KARANDINOS, M.G., } 2001 .\end{array}$ & Grécia & \begin{tabular}{c|} 
Nicotiana tabacum \\
(Bel W3 e mais 8 \\
variedades)
\end{tabular} & Angiosperma & arbustiva & $\mathrm{O} 3$ & $\begin{array}{l}\text { induzida por } \\
\text { fumigação }\end{array}$ & ativa, laboratório & $\begin{array}{l}1 \text { semana - } \\
7 \mathrm{~h} / \text { dia }\end{array}$ & porcentagem de área foliar necrosada & reação & \\
\hline $\begin{array}{c}\text { SAITANIS, C.J.; } \\
\text { KARANDINOS, M.G., } 2001 .\end{array}$ & $\begin{array}{l}14 \text { localidades na } \\
\text { zona, Grécia }\end{array}$ & $\begin{array}{l}\text { Nicotina tabacum } \\
\text { (Bel W3 e KK 6/5) }\end{array}$ & Angiosperma & arbustiva & $\mathrm{O} 3$ & $\begin{array}{l}\text { proveniente de área } \\
\text { urbana e industrial }\end{array}$ & ativa, campo & 3 meses & índice de injúrias visíveis & reação & \\
\hline $\begin{array}{c}\text { SAITANIS, C.J.; } \\
\text { KARANDINOS, M.G., } 2001 . \\
\end{array}$ & Pournaria, Grécia & \begin{tabular}{l|} 
Nicotina Tabacum \\
(Bel W3 e KK 6/5)
\end{tabular} & Angiosperma & arbustiva & $\mathrm{O} 3$ & ausente & ativa, campo & 38 dias & $\begin{array}{c}\text { concentração de O3 na troposfera; } \\
\text { índice de injúrias visíveis }\end{array}$ & reação & \\
\hline $\begin{array}{c}\text { SAITANIS, C.J.; } \\
\text { KARANDINOS, M.G., 2002. }\end{array}$ & Grécia & \begin{tabular}{c|} 
Nicotiana tabacum \\
(BelW3 e mais 6 \\
variedades)
\end{tabular} & Angiosperma & arbustiva & $\mathrm{O} 3$ & fumigação artificial & $\begin{array}{l}\text { ativa, estufa com } \\
\text { ambiente controlado }\end{array}$ & $\begin{array}{l}20 \text { dias - } \\
\text { 8h/dia }\end{array}$ & \begin{tabular}{|c|} 
índice de injúrias visíveis das folhas; \\
densidade de estômatos; atividade \\
fotossintética; condutância estomatal
\end{tabular} & reação & \begin{tabular}{|c|} 
Outros parâmetros \\
analisados: peso secoo \\
de folhas, caule e raiz
\end{tabular} \\
\hline $\begin{array}{l}\text { SAITANIS, C.J.; RIGA- } \\
\text { KARANDINOS, A.N.; } \\
\text { KARANDINOS, M.G., 2001. }\end{array}$ & Atenas, Grécia & $\begin{array}{l}\text { Nicotiana tabacum } \\
\text { (Bel - W3 e mais } 7 \\
\text { variedades) }\end{array}$ & Angiosperma & arbustiva & $\mathrm{O} 3$ & induzida & ativa, laboratório & $\begin{array}{l}20 \text { dias para } \\
\text { baixa } \\
\text { concentração } \\
\text { de O3; } 24 \mathrm{~h} \\
\text { para alta } \\
\text { concentração } \\
\end{array}$ & \begin{tabular}{|c|} 
degradação clorofila; índice de \\
injúrias visiveis; taxa fotossintética de \\
campo
\end{tabular} & reação & \\
\hline $\begin{array}{l}\text { SAMECKA-CYMERMAN, } \\
\text { A.; KEMPERS, A. J., } 1999 .\end{array}$ & $\begin{array}{c}\text { Wroclaw e } \\
\text { proximidades, Polônia }\end{array}$ & Ilex aquifolium & Angiosperma & arbórea & $\begin{array}{l}\text { Metais: Ni, Cr, Co, V, } \\
\text { Zn, Mn, Pb, Cd, Cu, } \\
\text { Hg, Ba e Sr }\end{array}$ & $\begin{array}{l}\text { ambiente urbano: } \\
\text { veículos, indústrias, } \\
\text { calefação }\end{array}$ & passiva & $\begin{array}{c}\text { não } \\
\text { especificado }\end{array}$ & $\begin{array}{l}\text { concentração de metais nas folhas e } \\
\text { no solo }\end{array}$ & acumulação & $\begin{array}{c}\text { Espécies utilizadas: } \\
\text { aptas a } \\
\text { monitoramento de } \mathrm{Hg}\end{array}$ \\
\hline $\begin{array}{l}\text { SAMECKA-CYMERMAN, } \\
\text { A.; KEMPERS, A. J., } 1999 .\end{array}$ & $\begin{array}{c}\text { Wroclaw e } \\
\text { proximidades Polônia }\end{array}$ & $\begin{array}{l}\text { Mahonia } \\
\text { aquifolium }\end{array}$ & Angiosperma & arbustiva & $\begin{array}{l}\text { Metais: Ni, Cr, Co, V, } \\
\text { Zn, Mn, Pb, Cd, Cu, } \\
\text { Hg, Ba e Sr }\end{array}$ & $\begin{array}{l}\text { ambiente urbano: } \\
\text { veículos, indústrias, } \\
\text { calefaçãa }\end{array}$ & passiva & $\begin{array}{c}\text { não } \\
\text { especificado }\end{array}$ & $\begin{array}{l}\text { concentração de metais nas folhas e } \\
\text { no solo }\end{array}$ & acumulação & $\begin{array}{c}\text { Espécies utilizadas: } \\
\text { aptas a } \\
\text { monitoramento de } \mathrm{Hg}\end{array}$ \\
\hline $\begin{array}{l}\text { SAMECKA-CYMERMAN, } \\
\text { A.; KEMPERS, A. J., } 1999 .\end{array}$ & $\begin{array}{c}\text { Wroclaw e } \\
\text { proximidades Polônia }\end{array}$ & $\begin{array}{l}\text { Rododendron } \\
\text { catawbiense }\end{array}$ & Angiosperma & arbustiva & \begin{tabular}{|} 
Metais pesados: $\mathrm{Ni}, \mathrm{Cr}$, \\
Co, V, Zn, Mn, Pb, Cd, \\
Cu, Hg, Ba e Sr
\end{tabular} & $\begin{array}{l}\text { ambiente urbano: } \\
\text { veículos, indústrias, } \\
\text { calefação }\end{array}$ & passiva & $\begin{array}{c}\text { não } \\
\text { especificado }\end{array}$ & $\begin{array}{l}\text { concentração de metais nas folhas e } \\
\text { no solo }\end{array}$ & acumulação & \begin{tabular}{|c|}
$\mathrm{Ni}, \mathrm{Cr}, \mathrm{Co}, \mathrm{Cd}$ - \\
contaminação via \\
atmosfera; $\mathrm{Zn}, \mathrm{Pb}, \mathrm{Hg}$ \\
- contaminação solo e \\
atmosfera \\
\end{tabular} \\
\hline SCERBO, R. et al., 1999 & $\begin{array}{c}\text { Província de Livorno, } \\
\text { Itália }\end{array}$ & Xanthoria parietina & Líquen & & $\begin{array}{l}\text { Metais: As, } \mathrm{Cd}, \mathrm{Cr}, \mathrm{Ni} \\
\text { Pb, V, Zn, } \mathrm{Hg}\end{array}$ & industrial, tráfego & passiva & 1 ano & $\begin{array}{c}\text { concentração de metais e amostras de } \\
\text { liquens expostos, IAP }\end{array}$ & $\begin{array}{l}\text { acumulação/ } \\
\text { reação }\end{array}$ & \begin{tabular}{|c|} 
IAP - Índice de Pureza \\
Atmosférica baseada \\
na freqüência de sp de \\
líquens sensíveis à \\
poluição \\
\end{tabular} \\
\hline $\begin{array}{l}\text { SCHRAUDNER, M. et } \\
\text { al.,1998. }\end{array}$ & Alemanha & \begin{tabular}{|c|} 
Nicotiana tabacum \\
Bel W3 (sensível) e \\
Bel B (resistente) \\
\end{tabular} & Angiosperma & arbustiva & $\mathrm{O} 3$ & $\begin{array}{l}\text { induzida por } \\
\text { fumigação }\end{array}$ & ativa, laboratório & 5 horas & \begin{tabular}{|c|}
$\begin{array}{c}\text { produção de ROIs nas } 2 \text { variedades de } \\
\text { tabaco; atividades da enzima } \\
\text { peroxidase }\end{array}$ \\
\end{tabular} & reação & \begin{tabular}{|c|} 
ROIs: espécies \\
intermediárias e reativas \\
de oxigênio, derivadas \\
do ozônio $(\mathrm{OH}, \mathrm{H} 2, \mathrm{O} 2)$ \\
\end{tabular} \\
\hline SILVA, L.C. et al., 2000. & Viçosa, MG, Brasil & Gallezia gorazema & Angiosperma & arbórea & $\mathrm{F}$ & chuva simulada & ativa, laboratório & 10 dias & $\begin{array}{c}\text { manchas necróticas e cloróticas, conc. } \\
\text { F, crescimento plântulas e mudas } \\
\end{array}$ & reação & $\begin{array}{c}\text { Utilizadas plântuluas e } \\
\text { mudas; } 2^{\circ} \text { espécie } \\
\text { mais sensivel }\end{array}$ \\
\hline SILVA, L.C. et al., 2000. & Viçosa, MG, Brasil & Genipa americana & Angiosperma & arbórea & $\mathrm{F}$ & chuva simulada & ativa, laboratório & 10 dias & $\begin{array}{l}\text { manchas necróticas e cloróticas, conc. } \\
\text { F, crescimento plântulas e mudas }\end{array}$ & resiste & \\
\hline
\end{tabular}




\begin{tabular}{|c|c|c|c|c|c|c|c|c|c|c|c|}
\hline Referência & $\begin{array}{l}\text { Local do estudo } \\
\text { Cidade e País }\end{array}$ & Espécie & $\begin{array}{c}\text { Divisão / Ordem } \\
\text { Botânica }\end{array}$ & Hábito & Poluentes & Fonte de poluicãa & $\begin{array}{c}\text { Exposição da planta } \\
\text { ativa/passiva; } \\
\text { laboratório/campo }\end{array}$ & $\begin{array}{l}\text { Tempo de } \\
\text { exposição }\end{array}$ & Parâmetros analisados & $\begin{array}{c}\text { Tipo de } \\
\text { bioindicador } \\
\text { reação/ } \\
\text { acumulação }\end{array}$ & Observações \\
\hline SILVA, L.C. et al., 2000. & Viçosa, MG, Brasil & Joannesia princeps & Angiosperma & arbórea & $\mathrm{F}$ & chuva simulada & ativa, laboratório & 10 dias & $\begin{array}{c}\text { manchas necróticas e cloróticas, conc. } \\
\text { F, crescimento plântulas e mudas }\end{array}$ & reação (plântulas) & $\begin{array}{c}\text { utilizadas plântulas e } \\
\text { mudas }\end{array}$ \\
\hline SILVA, L.C. et al., 2000. & Viçosa, MG, Brasil & $\begin{array}{l}\text { Peltophorum } \\
\text { dubium }\end{array}$ & Angiosperma & arbórea & $\mathrm{F}$ & chuva simulada & ativa, laboratório & 10 dias & \begin{tabular}{|c|} 
manchas necróticas e cloróticas, conc. \\
F, crescimento plântulas e mudas
\end{tabular} & resistente & $\begin{array}{c}\text { utilizadas plântulas e } \\
\text { mudas }\end{array}$ \\
\hline SILVA, L.C. et al., 2000. & Viçosa, MG, Brasil & Spondias dulcis & Angiosperma & arbórea & $\mathrm{F}$ & chuva simulada & ativa, laboratório & 10 dias & $\begin{array}{l}\text { manchas necróticas e cloróticas, conc. } \\
\text { F, crescimento plântulas e mudas }\end{array}$ & reação & $\begin{array}{c}\text { utilizadas plântulas e } \\
\text { mudas; espécie mais } \\
\text { sensível }\end{array}$ \\
\hline SUMITA, N.M. et al., 2003. & São Paulo, Brasil & $\begin{array}{l}\text { Tradescantia } \\
\text { pallida arar. } \\
\text { purpurea }\end{array}$ & Angiosperma & $\begin{array}{l}\text { ornamental, } \\
\text { herbácea }\end{array}$ & não especificado & veículos & ativa, campo & 14 meses & $\begin{array}{c}\text { concentrações de elementos-traço, } \mathrm{pH} \\
\text { solo }\end{array}$ & acumulação & \begin{tabular}{|c|} 
espécie utilizada no \\
monitoramento do \\
potencial genotóxico \\
de substâncias; pode \\
ser bioacumuladora de \\
metais \\
\end{tabular} \\
\hline $\begin{array}{l}\text { SZAREK-LUKASZEWSKA, } \\
\text { G.; GRODZINSKA, K; } \\
\text { BRANIEWSKI, S., 2002. } \\
\end{array}$ & Kraków, Polônia & $\begin{array}{l}\text { Pleurozium } \\
\text { schreberi }\end{array}$ & Briófita, musgo & epífita & $\begin{array}{l}\text { Metais: } \mathrm{Cd}, \mathrm{Cr}, \mathrm{Cu}, \mathrm{Fe}, \\
\quad \mathrm{Pb} \text { e Zn }\end{array}$ & industrial (siderurgia) & passiva & $\begin{array}{c}\text { não } \\
\text { especificado }\end{array}$ & $\begin{array}{l}\text { concentração dos elementos em } \\
\text { amostras de musgos nativos }\end{array}$ & acumulação & $\begin{array}{c}\text { experimento } \\
\text { conduzido na Floresta } \\
\text { de Niepolomice }\end{array}$ \\
\hline $\begin{array}{l}\text { TONCELLLI, M.L.; } \\
\text { LORENZINI, G., } 1999 .\end{array}$ & La Spezia, Itália & $\begin{array}{c}\text { Nicotiana tabacum } \\
\text { (Bel-W3 e Bel B) } \\
\text { mudas de } 2 \text { meses }\end{array}$ & Angiosperma & arbustiva & $\mathrm{O} 3$ & não identificada & ativa, campo & $\begin{array}{l}1 \text { mês (3 } \\
\text { vezes) }\end{array}$ & $\begin{array}{l}\text { estimativa visual da porcentagem de } \\
\text { área foliar com injúrias; conc. O3 na } \\
\text { troposfera }\end{array}$ & reação & $\begin{array}{c}\text { cultivar Bel-B } \\
\text { resistente e } \\
\text { assintomático ao O3 }\end{array}$ \\
\hline $\begin{array}{l}\text { TONCELLI, M.L.; } \\
\text { LORENZINI, G., } 1999 .\end{array}$ & La Spezia, Itália & \begin{tabular}{|c|} 
Nicotiana tabacum \\
(Bel-W3 e Bel B) \\
plântulas de 11 dias
\end{tabular} & Angiosperma & arbustiva & $\mathrm{O} 3$ & não identificada & ativa, campo & $\begin{array}{l}1 \text { semana }(12 \\
\text { veses) }\end{array}$ & \begin{tabular}{|l} 
estimativa visual da porcentagem de \\
área dos cotilédones recoberta com \\
injúrias; conc. O3 troposférico
\end{tabular} & reação & $\begin{array}{c}\text { cultivar Bel-B } \\
\text { resistente e } \\
\text { assintomático ao O3 }\end{array}$ \\
\hline $\begin{array}{l}\text { TONNEIJCK, A.E.G. et al., } \\
2003 .\end{array}$ & Holanda & \begin{tabular}{c|} 
Petunia \\
nyctaginiflora; \\
Tagetes erecta \\
\end{tabular} & Angiosperma & herbácea & Etileno (VOC) & $\begin{array}{c}\text { industrial (manufatura } \\
\text { de polietileno) }\end{array}$ & ativa, campo & 10 semanas & $\begin{array}{c}\text { número de flores por espécie; } \\
\text { estimativa visual de crescimento; } \\
\text { concentração atmosférica de etileno }\end{array}$ & reação & \\
\hline $\begin{array}{l}\text { TRIMBACHER, C.; WEIS, } \\
\text { P., 1999. }\end{array}$ & Áustria & Picea abies & Coniferofita & arbórea & SO2, poeira & industrial e urbano & passiva & $\begin{array}{c}\text { não } \\
\text { especificado }\end{array}$ & \begin{tabular}{|c|} 
concentração dos elementos químicos \\
em amostras dea acículas: S, P, K, Ca, \\
Mg, Mn, Zn, Cu, Fe, Al; \\
características da cera epistomatal de \\
acículas
\end{tabular} & $\begin{array}{l}\text { reação (cera } \\
\text { epistomatal); } \\
\text { acumulação } \\
\text { (elementos } \\
\text { químicos) } \\
\end{array}$ & \\
\hline $\begin{array}{l}\text { UHLIG, C.; JUNTTILA, O., } \\
2001 .\end{array}$ & $\begin{array}{l}\text { Sor-Varanger } \\
\text { Noruega }\end{array}$ & $\begin{array}{l}\text { Empetrum } \\
\text { hermaphroditum }\end{array}$ & Angiosperma & arbustiva & $\begin{array}{c}\text { Metais: Al, Cu, Fe, Mn, } \\
\text { Ni, Ca, K, P e S }\end{array}$ & industrial (metalurgia) & passiva & $\begin{array}{c}\text { não } \\
\text { especificado }\end{array}$ & $\begin{array}{c}\text { concentração dos elementos em folhas } \\
\text { das espécies selecionadas; } \\
\text { concentraçôses de Ni no solo }\end{array}$ & acumulação & \begin{tabular}{|c|} 
experimento \\
conduzido na Floresta \\
Boreal e Tundra \\
\end{tabular} \\
\hline $\begin{array}{l}\text { UHLIG, C.; JUNTTILA, O., } \\
2001 .\end{array}$ & $\begin{array}{l}\text { Sor-Varanger } \\
\text { Noruega }\end{array}$ & Vaccinium myrtillus & Angiosperma & arbustiva & $\begin{array}{c}\text { Metais: Al, Cu, Fe, Mn, } \\
\text { Ni, Ca, K, P e S }\end{array}$ & industrial (metalurgia) & passiva & $\begin{array}{c}\text { não } \\
\text { especificado }\end{array}$ & $\begin{array}{c}\text { concentração dos elementos em folhas } \\
\text { das espécies selecionadas; } \\
\text { concentraçốes de Ni no solo }\end{array}$ & acumulação & \begin{tabular}{|c|} 
experimento \\
conduzido na Floresta \\
Boreal e Tundra \\
\end{tabular} \\
\hline $\begin{array}{l}\text { VASCONCELOS, M.T.S.D.; } \\
\text { TAVATES, H.M.F.,1998 }\end{array}$ & $\begin{array}{l}\text { Cidade do Porto, } \\
\text { Portugal }\end{array}$ & $\begin{array}{c}\text { Sphagnum } \\
\text { auriculatum }\end{array}$ & Briófita, musgo & & $\begin{array}{l}\text { Metais: Cr, Cu, Fe, Mn, } \\
\text { Ni, Pb e Zn }\end{array}$ & tráfego de veículos & ativa & 80 dias & \begin{tabular}{|c|} 
concentração dos metais nas amostras \\
de musgos expostas; concentração dos \\
metais nos filtros de amostragem do \\
ar
\end{tabular} & acumulação & \\
\hline $\begin{array}{l}\text { VERGÉ, X.; CHAPUIS, A.; } \\
\text { DELPOUX, M., } 2002 .\end{array}$ & não especificado & $\begin{array}{l}\text { Nicotiana tabacum } \\
\text { Bel-W3 }\end{array}$ & Angiosperma & arbustiva & $\mathrm{O} 3$ & não especificado & ativa, campo & 68 dias & $\begin{array}{c}\text { índice de danos foliares; concentração } \\
\text { de ozônio no ar }\end{array}$ & reação & \\
\hline $\begin{array}{l}\text { WADLEIGH, M.A.; BLAKE, } \\
\text { D.M., } 1999\end{array}$ & $\begin{array}{l}\text { Ilha de } \\
\text { Newfoundland, } \\
\text { Canadá }\end{array}$ & $\begin{array}{c}\text { Alectoria } \\
\text { sarmentosa }\end{array}$ & Líquen & epífita & $\mathrm{s}$ & $\begin{array}{c}\text { transporte e deposição } \\
\text { de poluentes de } \\
\text { grandes distâncias e } \\
\text { fontes locais }\end{array}$ & passiva & $\begin{array}{c}\text { não } \\
\text { especificado }\end{array}$ & $\begin{array}{l}\text { concentração de S e composição } \\
\text { isotópica de S nas amostras de liquens } \\
\text { coletatadas }\end{array}$ & acumulação & \begin{tabular}{|c|} 
fontes locais: \\
termoelétrica, fábricas \\
de papel, refinária de \\
petróleo
\end{tabular} \\
\hline $\begin{array}{l}\text { WAPPELHORST O. et al., } \\
2000 .\end{array}$ & $\begin{array}{c}\text { Alemanha, República } \\
\text { Tcheca, Polônia }\end{array}$ & $\begin{array}{l}\text { Pleurozium } \\
\text { schreberi; } \\
\text { Polytrichum } \\
\text { formosum }\end{array}$ & Briófita, Musgo & & $\begin{array}{c}\text { elementos químicos e } \\
\text { MP }\end{array}$ & industrial & passiva & 2 a 3 anos & $\begin{array}{c}\text { concentração dos elementos químicos } \\
\text { nas amostras de musgos expostos }\end{array}$ & acumulação & \begin{tabular}{|c|} 
concentrações dos \\
elementos químicos \\
nos musgos plotadas \\
em mapa e comparado \\
com incidência de \\
doenças em seres \\
humanos \\
\end{tabular} \\
\hline
\end{tabular}




\begin{tabular}{|c|c|c|c|c|c|c|c|c|c|c|c|}
\hline Referência & $\begin{array}{l}\text { Local do estudo } \\
\text { Cidade e País }\end{array}$ & Espécie & $\begin{array}{l}\text { Divisão / Ordem } \\
\text { Botânica }\end{array}$ & Hábito & Poluentes & Fonte de poluição & $\begin{array}{c}\text { Exposicão da planta } \\
\text { ativa/passiva; } \\
\text { laboratório/campo }\end{array}$ & $\begin{array}{l}\text { Tempo de } \\
\text { exposição }\end{array}$ & Parâmetros analisados & $\begin{array}{c}\text { Tipo de } \\
\text { bioindicador } \\
\text { reação/ } \\
\text { acumulação }\end{array}$ & Observações \\
\hline WEISS, D. et al., 1999 & $\begin{array}{l}\text { Suíça (várias } \\
\text { localidades) }\end{array}$ & Sphagnum spp & Briófita, musgo & & $\mathrm{Pb}$ & $\begin{array}{l}\text { ambiente urbano: } \\
\text { queima combustível, } \\
\text { processo industriais }\end{array}$ & \begin{tabular}{|l|} 
passiva (amostras nos \\
herbários de Genebra)
\end{tabular} & variável & $\begin{array}{l}\text { composição de isśtopos estáveis do } \\
\qquad \mathrm{Pb}\end{array}$ & acumulação & $\begin{array}{l}\text { datação dos isótopos } \\
\text { para avaliar fontes de } \\
\mathrm{Pb}\end{array}$ \\
\hline XIAO, Z. et al., 1998. & Malmö, Suécia & Lolium multiflorum & Angiosperma & $\begin{array}{l}\text { herbácea } \\
\text { (gramínea) }\end{array}$ & $\mathrm{Hg}$ & $\begin{array}{l}\text { industrial, tráfego de } \\
\text { veículos }\end{array}$ & ativa, estufa e campo & $\begin{array}{l}5 \text { meses/ ano, } \\
\text { em } 5 \text { anos }\end{array}$ & \begin{tabular}{|c|} 
concentração de Hg em amostras de \\
folhas; cálculo estimativo de \\
deposição seca e total de Hg
\end{tabular} & acumulação & \\
\hline $\begin{array}{c}\text { ZAFAR, I.M.; } \\
\text { MUHAMMAD, S., } 2000\end{array}$ & Karichi, Paquistão & Azadirachta indica & Angiosperma & arbórea & não especificado & veículos & passiva & 10 semanas & \begin{tabular}{|c|}
$\begin{array}{c}\text { produção de sementes e crescimento } \\
\text { ramos }\end{array}$ \\
\end{tabular} & reação & $\begin{array}{l}\text { espécie considerada } \\
\text { muito sensível }\end{array}$ \\
\hline $\begin{array}{c}\text { ZAFAR, I.M.; } \\
\text { MUHAMMAD, S., } 2000\end{array}$ & Karichi, Paquistão & $\begin{array}{l}\text { Guaiacum } \\
\text { officinale }\end{array}$ & Angiosperma & arbórea & não especificado & veículos & passiva & 10 semanas & \begin{tabular}{|c|} 
produção de sementes, crescimento de \\
ramos
\end{tabular} & reação & \\
\hline $\begin{array}{c}\text { ZAFAR, I.M.; } \\
\text { MUHAMMAD, S., } 2000\end{array}$ & Karichi, Paquistão & Eucalyptus sp & Angiosperma & arbórea & não especificado & veículos & passiva & 10 semanas & $\begin{array}{c}\text { produção de sementes, crescimento de } \\
\text { ramos }\end{array}$ & reação & \\
\hline
\end{tabular}




\subsection{Quanto ao uso de bioindicadores vegetais em processos de poluição atmosférica}

Foram identificadas 112 espécies utilizadas como bioindicadores vegetais de poluição atmosférica, sendo 75 espécies vegetais vasculares (64 Angiospermas e 11 Coniferofitas), 22 líquens e 15 musgos.

Os Quadros de número 8 a 11 trazem as relações completas das espécies encontradas, sejam elas pertencentes aos grupos das Angiospermas (Quadro 8), Coniferofitas (Quadro 9), musgos (Quadro 10) e líquens (Quadro 11). Nesses quadros são apresentadas informações sobre famílias botânicas, nomes científicos e populares e, sempre que disponível na bibliografia específica consultada, os registros de área de ocorrência ou de coleta de cada espécie nos diversos continentes, finalizando com informações sobre cultivo em território brasileiro. 
Quadro 8 - Relação das espécies vegetais referidas como bioindicadores de poluição atmosférica pertencentes à Divisão Angiospermae

\begin{tabular}{|c|c|c|c|c|c|}
\hline Família & Espécie & Nome vulgar & Área de ocorrência & Registros de coletas (6) & Cultivo/Adaptação no Brasil \\
\hline Anacardeaceae & Spondia dulcis & Cajá-manga & Cosmopolita tropical (11) & Nicarágua, Equador, Peru, Madagascar & Todo o país (11) \\
\hline Anacardiaceae & Spondia mombin & Cajaseira & AM até SP e MG (11) & $\begin{array}{l}\text { América Central: Belize, Costa Rica, El Salvador, Guatemala, Honduras, México, Nicaragua, Panamá, } \\
\text { Caribe; } \\
\text { América do Sul: Bolívia, Colômbia, Equador, Paraguai, Peru, Suriname, Venezuela; } \\
\text { África: Camarão, Gabão, Gana, Nigéria }\end{array}$ & AM até SP e MG (11) \\
\hline Anacardiaceae & Mangifera indica & Mangueira & & $\begin{array}{l}\text { América do Norte: EUA; } \\
\text { América Central: Panamá, Costa Rica, El Salvador, Honduras, Nicarágua, Caribe; } \\
\text { América do Sul: Bolívia, Equador, Paraguai, Peru; } \\
\text { África: Burundi, Camarão, Gabão, Madagascar, Nigéria, Tanzânia, Zaire; } \\
\text { Ásia: Îndia, Taiwan }\end{array}$ & \\
\hline Aросупасеае & Nerium oleander & Espirradeira & Região do Mediterrâneo (1) & $\begin{array}{l}\text { América do Norte: EUA; } \\
\text { América Central: Belize, Costa Rica, Guatemala, México, Nicarágua; } \\
\text { América do Sul: Bolívia, Equador, Paraguai; } \\
\text { África: Argélia, Comoros, Tanzânia; } \\
\text { Ásia: Irã, Taiwan }\end{array}$ & \\
\hline Aquifoliaceae & Ilex aquifolium & Azevinho & Europa (11) & EUA, Dinamarca, França, Grã Bretanha, Noruega, Alemanha & \\
\hline Arecaceae & Euterpe edulis & Juçara & $\begin{array}{c}\text { Brasil: sul da BA, MG, até RS; } \\
\text { GO, MS, SP, PR (4) }\end{array}$ & & $\begin{array}{c}\text { Sul da BA, MG, até RS; GO, } \\
\text { MS, SP, PR (4) }\end{array}$ \\
\hline Asclepiadaceae & Asclepias exaltata & & & EUA & \\
\hline Asteraceae & Lapsana communis & & & EUA, França, Alemanha & \\
\hline Asteraceae & Taraxacum officinale & Dente-de-leão & & $\begin{array}{l}\text { América do Norte: EUA; } \\
\text { América Central: Costa Rica, El Salvador, Guatemala, Honduras, México, Panamá; } \\
\text { América do Sul: Bolívia, Equador, Paraguai, Peru, Venezuela; } \\
\text { África: Uganda }\end{array}$ & Todo o país (11) \\
\hline Asteraceae & Tagetes ereta & Cravo-de-defunto & $\begin{array}{l}\text { Costa Rica, Guatemala, Hondura, } \\
\text { México, Nicarágua, Panamá (8) }\end{array}$ & & \\
\hline Balsaminaceae & Impatiens parviflora & & & Suíça & \\
\hline Berberidaceae & Mahonia aquifolium & & Am. Setentrional (11) & Canadá, EUA & \\
\hline Betulaceae & Alnus incana & & & Canadá, EUA & \\
\hline Betulaceae & Corylus avellana & Avelã & Europa, Norte da África, Ásia (1) & Eua, Noruega, República Geórgia & Região Sul (1) \\
\hline Betulaceae & Betula pendula & & & EUA, Cazaquistão, Mongólia, Rússia, China & \\
\hline Betulaceae & Betula papyrifera & & EUA, Canadá (9) & EUA & \\
\hline Bombacaceae & Adansonia sp & Baoba & África (1) & & Regiões quentes (1) \\
\hline Brassicaceae & Raphanus sativus & Rabanete & & $\begin{array}{l}\text { América do Norte: EUA; } \\
\text { América Central: Costa Rica, El Salvador, Honduras, México, Panamá; } \\
\text { América do Sul: Bolívia, Equador; } \\
\text { África: Madagascar, Tanzânia }\end{array}$ & \\
\hline Brassicaceae & Eruca sativa & Pinchão & $\begin{array}{l}\text { Europa, Ásia Ocidental, África } \\
\text { Setentrional (11) }\end{array}$ & EUA, México, Turquistão & Introduzida no Brasil \\
\hline Bromeliaceae & Tillandsia usneoides & Barba-de-velho & & $\begin{array}{l}\text { América do Norte: EUA; } \\
\text { América Central: Antilhas, Belize, Costa Rica, El Salvador, Guatemala, Honduras, Nicarágua, Caribe; } \\
\text { América do Sul: Argentina, Bolívia, Chile, Colômbia, Equador, Paraguai, Peru; }\end{array}$ & Todo o Brasil, exceto AM \\
\hline Bromeliaceae & Tillandsia capillaris & & & Argentina, Bolívia, Equador, Peru & \\
\hline Bromeliaceae & Tillandisia bulbosa & & Guiania até BA & Belize, Cosa Rica, México, Nicarágua, Panamá, Tabasco, Equador, Antilhas, Norte do Braasil & \\
\hline Bromeliaceae & Tillandisia caput-medusae & & & América Central: Costa Rica, El Salvador, Guatemala, México, Nicarágua, Panamá & \\
\hline Caesalpinoideae & Peltophorum dubium & Canafistula & $\begin{array}{c}\text { Brasil: BA, ES, RJ, MG, GO, MS, } \\
\text { PR (4) }\end{array}$ & & $\begin{array}{c}\text { BA, ES, RJ, MG, GO, MS, PR } \\
\text { (4) }\end{array}$ \\
\hline Caprifoliaceae & Sambucus racemosa & & & EUA, Bolívia, Holanda, Espanha & \\
\hline Commelinaceae & $\begin{array}{c}\text { Tradescantia pallida var. } \\
\text { purpurea }\end{array}$ & Trapoeraba roxa & $\begin{array}{l}\text { Nativa da América Central: } \\
\text { Honduras e Nicarágua (8) }\end{array}$ & Costa Rica, Honduras, México, Nicarágua, Panamá, Bolívia, Equador & \\
\hline
\end{tabular}




\begin{tabular}{|c|c|c|c|c|c|}
\hline Família & Espécie & Nome vulgar & Área de ocorrência & Registros de coletas (6) & Cultivo/Adaptação no Brasil \\
\hline Commelinaceae & Tradescantia (clone 02) & & & & \\
\hline Commelniaceae & Tradescantia (clone 4430) & & & & \\
\hline Cornaceae & Cornus sanguinea & & & EUA, França, Grã Bretanha & \\
\hline Empretaceae & Empetrum hermaphroditum & & & República Geórgia & \\
\hline Ericaceae & Rhododendron catawbiense & & América do Norte (11) & EUA & \\
\hline Ericaceae & Vaccinum myrtillus & & & EUA, República Geórgia & \\
\hline Euphorbiaceae & Joannesia princeps & Cotieira & Brasil: PA, BA, ES, MG, SP (4) & & PA, BA, ES, MG, SP (4) \\
\hline Euphorbiaceae & Hura crepitans & Assacu & $\begin{array}{l}\text { Região Amazônica e áreas } \\
\text { inundáveis (4) }\end{array}$ & $\begin{array}{l}\text { América Central: Antilhas, Costa Rica, Nicarágua, Panamá; } \\
\text { América do Sul: Bolívia, Colômbia, Suriname, Venezuela, Peru }\end{array}$ & \\
\hline Fabaceae & Trifolium repens & & & $\begin{array}{l}\text { América do Norte: Canadá, EUA; } \\
\text { América Central: Costa Rica, Honduras, México, Panamá; } \\
\text { América do Sul: Bolívia, Colômbia, Equador, Peru, Venezuela; } \\
\text { Europa: França, Grã Bretanha; } \\
\text { África: Madagascar, Tanzânia, Uganda }\end{array}$ & \\
\hline Fabaceae & Trifolium alexandrinum & & & & \\
\hline Fabaceae & Phaseolus vulgaris & Feijão comum & América do Sul (11) & $\begin{array}{l}\text { América do Norte: EUA; } \\
\text { América Central: Costa Rica, Guatemala, México, Nicarágua, Panamá; } \\
\text { América do Sul: Bolívia, Equador; } \\
\text { Ásia: China Índia, Filipinas }\end{array}$ & Todo o país (11) \\
\hline Fabaceae & Medicago sativa & & & $\begin{array}{l}\text { América do Norte: Canadá, EUA; } \\
\text { América Central: México; } \\
\text { América do Sul: Bolívia, Colômbia, Equador; } \\
\text { Europa: França; } \\
\text { África: Madagascar; } \\
\text { Ásia: Turquistão }\end{array}$ & \\
\hline Fagaceae & Quercus ilex & Carvalho & & EUA & \\
\hline Fagaceae & Quercus cerris & Carvalho & & EUA & \\
\hline Fagaceae & Quercus robur & Carvalho europeu & $\begin{array}{l}\text { Europa, Norte da África e Ásia } \\
\text { Ocidental (1) }\end{array}$ & EUA, Bolívia, Grã Bretanha & $\begin{array}{l}\text { Regiões de altitude no Sul do } \\
\text { país (1) }\end{array}$ \\
\hline Fagaceae & Quercus robur v. petrae & Carvalho & & República Geórgia & \\
\hline Gramineae & Lolium perene multiflorum & Azevem & Europa e Ásia (11) & $\begin{array}{l}\text { América do Norte: EUA; } \\
\text { América Central: Costa Rica, México, Panamá, Caribe; } \\
\text { América do Sul: Argentina, Bolívia, Brasil, Chile, Colômbia, Equador, Peru, Venezuela; } \\
\text { Ásia: Turquistão }\end{array}$ & \\
\hline Iridaceae & Gladiolus $s p$ & Palma-de-santa-rita & $\begin{array}{l}\text { América Central, Europa, Oriente } \\
\text { Médio, Africa (8) }\end{array}$ & & \\
\hline Lamiaceae & Stachys officinalis & & & EUA, Grã Bretanha & \\
\hline Lamiaceae & $\begin{array}{l}\text { Rosmarinus officinalis } \\
\text { prostattus }\end{array}$ & Alecrim & & $\begin{array}{l}\text { América do Norte: EUA; } \\
\text { América do Sul: Bolívia, Colômbia, Equador, Paraguai, Peru; } \\
\text { América Central: Caribe; } \\
\text { Ásia: Tanzânia }\end{array}$ & \\
\hline Lauraceae & Laurus nobilis & Louro & Região do Mediterrâneo (1) & $\begin{array}{l}\text { América do Norte: EUA; } \\
\text { América do Sul: Bolívia, Brasil, Paraguai, Peru }\end{array}$ & $\begin{array}{l}\text { Regiões de clima temperado ou } \\
\text { mais quentes (1) }\end{array}$ \\
\hline Liliaceae & Hemerocallis sp & & Ásia Temperada e Europa (8) & & \\
\hline Melastomataceae & Tibouchina pulchra & Manacá-da-serra & Brasil: SP, PR (Mata Atlântica) (7) & Panamá & SP, PR (Mata Atlântica) (7) \\
\hline Melastomataceae & Miconia pyrifolia & & $\begin{array}{l}\text { Brasil: BA, ES (Mata Atlântica) } \\
\text { (7) }\end{array}$ & & BA, ES (Mata Atlântica) (7) \\
\hline Melastomataceae & Miconia саbиси & & Brasil: SP (Mata Atlântica) (7) & & SP (Mata Atlântica) (7) \\
\hline Melastomataceae & Miconia cinnamomilolia & & & & \\
\hline Meliaceae & Melia azedarach & Cinamomo & Índia e China (1) & $\begin{array}{l}\text { América do Norte: EUA; } \\
\text { A. Central: Belize, Costa Rica, El Salvador, Guatemala, Honduras, México, Nicarágua, Panamá; Caribe } \\
\text { América do Sul: Bolívia, Colômbia, Equador, Paraguai, Peru; }\end{array}$ & Regiões Sul e Sudeste (1) \\
\hline
\end{tabular}




\begin{tabular}{|c|c|c|c|c|c|}
\hline Família & Espécie & Nome vulgar & Área de ocorrência & Registros de coletas (6) & Cultivo/Adaptação no Brasil \\
\hline Meliaceae & Azadirachta indica & Niim & $\begin{array}{l}\text { Ásia, Índia, Ceilão, Filipinas, } \\
\text { Indonésia e Malásia (1) }\end{array}$ & $\begin{array}{l}\text { América Central: Costa Rica, El Salvador, Guatemala, Honduras, México, Nicaragua, Panamá; Caribe } \\
\text { América do Sul: Bolívia, Colômbia, Equador, Paraguai, Peru; }\end{array}$ & \\
\hline Mimosoideae & Acacia sp & & & & \\
\hline Moraceae & Cecropia glaziovii & Embaúba vermelha & $\begin{array}{l}\text { Brasil: BA ao PR, na encosta } \\
\text { atlântica (5) }\end{array}$ & & BA ao PR (encosta atlântica) (5) \\
\hline Moraceae & Ficus $s p$ & & & & \\
\hline Myrtaceae & Eucalyptus $s p$ & Eucalipto & Austrália (1) & & \\
\hline Myrtaceae & Psidium guayava & Goiabeira & $\begin{array}{l}\text { Brasil: Floresta Pluvial Atlântica, } \\
\text { do RJ ao RS (4) }\end{array}$ & & $\begin{array}{l}\text { Brasil: mata, cerrado, suporta } \\
\text { inundação (7) }\end{array}$ \\
\hline Myrtaceae & Psidium cattleyaum & Araçá & $\begin{array}{l}\text { Brasil: Floresta Pluvial Atlântica: } \\
\text { BA ao RS (4); SP, RS (7) }\end{array}$ & & $\begin{array}{l}\text { Floresta Pluvial Atlântica: BA ao } \\
\text { RS (4); SP, RS (7) }\end{array}$ \\
\hline Phytolaccaceae & Gallesia gorazema & Pau d'alho & $\begin{array}{l}\text { Brasil: BA, ES, MG, GO, MT, } \\
\text { MS, SP, PR (4) }\end{array}$ & & \\
\hline Pittosporaceae & Pittosporum tobira & & & EUA & \\
\hline Ranunculaceae & Clematis vitalba & & & EUA, República Geórgia & \\
\hline Rosaceae & Amelanchier alnifolia & & & Canadá, EUA & \\
\hline Rosaceae & Alchemilla sp & & & & \\
\hline Rosaceae & Prunus serotina & & & EUA, Guatemala, México, Bolívia, Equador & \\
\hline Rosaceae & Sobus aucuparia & & & Canadá, EUA, Bélgica & \\
\hline Rubiaceae & Genipa americana & Jenipapo & $\begin{array}{l}\text { Todo o Brasil (4) } \\
\text { BA, ES (7) }\end{array}$ & & $\begin{array}{l}\text { Todo o Brasil (4) } \\
\text { BA, ES (7) }\end{array}$ \\
\hline Salicaceae & Populus nigra & Álamo & Europa (1) & $\begin{array}{l}\text { América: Canadá, EUA, Bolívia; } \\
\text { Ásia: Cazaquistáo, República Geórgia }\end{array}$ & \\
\hline Solanaceae & Nicotiana tabacum & Tabaco & $\begin{array}{l}\text { América Central, Peru, Equador } \\
\text { (8) }\end{array}$ & EUA, Belize, Costa Rica, Guatemala, Honduras, México, Nicarágua, Panamá & \\
\hline Solanaceae & Petunia nyctaginiflora & Petúnia branca & Brasil: SP ao RS (11) & $\begin{array}{l}\text { Argentina, Bolívia, Brasil, Paraguai, Uruguai; } \\
\text { China, Butão e Índia }\end{array}$ & \\
\hline Tiliaceae & Corchorus olitorius & Juta azul & & & \\
\hline Ulmaceae & Ulmus montana & & & & \\
\hline Urticaceae & Urtica urens & Urtiga & América (8) & EUA, México, Argentina, Bolívia, Chile, Brasil, Colômbia, Equador, Peru, Uruguai & \\
\hline Verbenaceae & Gmelina arborea & & & Belize, Costa Rica, El Salvador, Honduras, México, Nicarágua, Brasil, Colômbia & \\
\hline Vitaceae & $\begin{array}{l}\text { Parthenocissus } \\
\text { quinquefolia }\end{array}$ & & & $\begin{array}{l}\text { América: Canadá, EUA, México, Bolívia; Caribe; } \\
\text { Europa: Holanda; } \\
\text { África: Madagscar, Zimbábue; } \\
\text { Ásia: China, Java, Filipinas }\end{array}$ & \\
\hline Zygophylaceae & Guaiacum officinale & Guaiaco & & Honduras, Colômbia, Venezuela, Caribe & \\
\hline
\end{tabular}
(1) Lorenzi et al. (2003)
(4) Lorenzi (1992)
(7) Base de Dados Tropicais (2004)
(2) Graf (1978)
(5) Lorenzi (1998)
(3) Graf (1985)
(2004)
(11) Corrêa (1926-1978); Corrêa (1969-1978)
(8) Flora Mesoameria (2004)
(9) Kooper, Lindroth, Nordheim (2001) 
Quadro 9 - Relação de espécies vegetais referidas como bioindicadores de poluição atmosférica pertencentes à Divisão Coniferophyta

\begin{tabular}{|c|c|c|c|c|c|}
\hline Família & Espécie & Nome vulgar & Ocorrência & $\begin{array}{ll}\text { Registros de coletas (6) } \\
\end{array}$ & Cultivo e adaptação no Brasil \\
\hline Cupressaceae & Juniperus communis & Junípero comum & $\begin{array}{l}\text { Hemisfério Norte: América do } \\
\text { Norte, Europa e Ásia (1) }\end{array}$ & $\begin{array}{l}\text { América do Norte: Alasca; } \\
\text { Europa: Áustria, Dinamarca, França, Grã Bretanha, Grécia, Itália, Holanda, Noruega, Polônia, } \\
\text { Romênia, Espanha, Suíça, Alemanha; } \\
\text { África: Marrocos; } \\
\text { Ásia: Japão, Rússia }\end{array}$ & $\begin{array}{l}\text { Regiões de altitudes do Sul e } \\
\text { Sudeste (1) }\end{array}$ \\
\hline Cupressaceae & Cupressus sempervirens & $\begin{array}{l}\text { Cipreste do } \\
\text { Mediterrâneo }\end{array}$ & $\begin{array}{c}\text { Sul do Europa, ilhas do } \\
\text { Mediterrâneo, Ásia Menor e } \\
\text { Rússia (1) }\end{array}$ & $\begin{array}{l}\text { América: EUA, Bolívia, Brasil, Colômbia; } \\
\text { Europa: França, Grã Bretanha, Grécia, Itália, Alemanha; } \\
\text { Caribe; } \\
\text { Ásia: China, Irã, Israel, Síria }\end{array}$ & Região Sul (1) \\
\hline Cupressaceae & $\begin{array}{l}\text { Juniperus sabina } \\
\text { tamarisfolia }\end{array}$ & & & $\begin{array}{l}\text { América do Norte: EUA; Canadá; } \\
\text { Europa: Áustria, França, Grã Bretanha, Itália, Romênia, Espanha, Suíça, Alemanha; }\end{array}$ & \\
\hline Pinaceae & Picea abies & Pinheiro da Noruega & $\begin{array}{l}\text { Regiões montanhosas da Europa } \\
\text { e Ásia (1) }\end{array}$ & América do Norte; China & $\begin{array}{l}\text { Regiões do altitude do Sul e } \\
\text { Sudeste (1) }\end{array}$ \\
\hline Pinaceae & Pinus sylvestris & Pinho-de-riga & Europa e Ásia (1) & EUA, México, Rússia, Nova Zelândia; & \\
\hline Pinaceae & Pinus halepensis & Pinheiro de Jerusalém & Portugal ao Afeganistão (2) & EUA, Espanha, Nova Zelândia & \\
\hline Pinaceae & Pinus thunbergii & $\begin{array}{l}\text { Pinheiro negro do } \\
\text { Japão }\end{array}$ & Japão (2) & EUA, China & \\
\hline Pinaceae & Pinus radiata & Pinheiro de Monterey & EUA (1) & EUA, Bolívia, Equador & \\
\hline Pinaceae & Pinus taeda & Pinheiro americano & EUA (1) & EUA & Região Sul (1) \\
\hline Pinaceae & Pinus pinea & Pinheiro litorâneo & Sul da Europa (1) & EUA, Nova Zelândia & $\begin{array}{l}\text { Regiões litorâneas do Sul do } \\
\text { Brasil (1) }\end{array}$ \\
\hline Pinaceae & Larix decidua & & & EUA, Noruega & \\
\hline
\end{tabular}

(1) Lorenzi et al. (2003)

(6) Missouri Botanical Garden's - W3T (2004) 
Quadro 10 - Musgos Bioindicadores de Poluição Atmosférica

\begin{tabular}{|c|c|c|}
\hline Família & Espécie & Registros de Coleta (10) \\
\hline Bryaceae & Bryum argenteum & $\begin{array}{l}\text { América do Norte: Canadá, EUA; } \\
\text { América Central: Costa Rica, Guatemala, Honduras, } \\
\text { México; } \\
\text { América do Sul: Argentina, Bolívia, Brasil, Chile, } \\
\text { Colômbia, Equador, Peru, Venezuela; } \\
\text { Caribe } \\
\text { Europa: República Tcheca, Dinamarca, Grã Bretanha, } \\
\text { Irlanda, Polônia, Alemanha; } \\
\text { África: Botsuana, Camarão, Etiópia, Quênia, Malaui, } \\
\text { Namíbia, Nigéria, África do Sul, Zimbábue, Tanzânia; } \\
\text { Ásia: China, Israel, Japão, Cazaquistão, Malásia, } \\
\text { Mongólia, Nepal, Filipinas, Rússia, Taiwan, Tailândia, } \\
\text { Vietnã. }\end{array}$ \\
\hline Dicranaceae & Dicranum scoparium & $\begin{array}{l}\text { América do Norte: Canadá, EUA; } \\
\text { Europa: Áustria, Bulgária, Córsega, Rep. Tcheca, } \\
\text { Finlândia, Grã Bretanha, Hungria, Irlanda, Holanda, } \\
\text { Noruega, Polônia, Portugal, Espanha, Alemanha; } \\
\text { Ásia: China, Japão, Cazaquistão, Rep. Geórgia, Rússia, } \\
\text { Sri Lanka, Taiwan, Turquia. }\end{array}$ \\
\hline Brachytheciaceae & Eurhynchium angustirete & Finlândia, Alemanha, Iugoslávia, Taiwan. \\
\hline Hylocomiaceae & Hylocomium splendens & $\begin{array}{l}\text { América do Norte: Canadá, EUA; } \\
\text { Caribe } \\
\text { Europa: Áustria, Bélgica, República Tcheca, Finlândia, } \\
\text { Grã Bretanha, Alemanha; } \\
\text { África: Tanzânia; } \\
\text { Ásia: China, Cazaquistão, República Geórgia, Rússia, } \\
\text { Taiwan. }\end{array}$ \\
\hline Hypnaceae & Hypnum cupressiforme & $\begin{array}{l}\text { América do Norte: Canadá, EUA } \\
\text { América Central: Honduras, México; } \\
\text { América do Sul: Chile, Colômbia, Equador, Peru; } \\
\text { Europa: República Tcheca, Noruega, Polônia, Itália, } \\
\text { Suécia, Alemanha; } \\
\text { África: África do Sul, Tanzânia, Uganda; } \\
\text { Ásia: China, Cazaquistão, Mongólia, Rússia, Turquia; } \\
\text { Oceania: Austrália, Nova Zelândia. }\end{array}$ \\
\hline Hylocomiaceae & Pleurozium schreberi & $\begin{array}{l}\text { América do Norte: Canadá, EUA; } \\
\text { América Central: Costa Rica, Panamá; } \\
\text { América do Sul: Bolívia, Colômbia, Equador, Peru; } \\
\text { Europa: Finlândia, França, Suíça, Alemanha; } \\
\text { Ásia: China, Rússia, Taiwan. }\end{array}$ \\
\hline Polytrichaceae & Polytrichum formosum & $\begin{array}{l}\text { América do Norte: Canadá, EUA; } \\
\text { América do Sul: Brasil; } \\
\text { Europa: Áustria, Alemanha; } \\
\text { Ásia: China, Japão, República Geórgia; } \\
\text { Oceania: Nova Zelândia. } \\
\end{array}$ \\
\hline
\end{tabular}


continuação

\begin{tabular}{|c|c|c|}
\hline Família & Espécie & Registros de Coleta (10) \\
\hline Grimmiaceae & Racomitrium langinosum & $\begin{array}{l}\text { América do Norte: Canadá, EUA; } \\
\text { América Central: Costa Rica; } \\
\text { América do Sul: Argentina, Bolívia, Chile, Colômbia, } \\
\text { Equador, Peru; } \\
\text { Europa: Córsega, Finlândia, Grã Bretanha, Irlanda, } \\
\text { Noruega, Polônia, Alemanha; } \\
\text { Ásia: China, Japão, Rússia, Taiwan; } \\
\text { Oceania. }\end{array}$ \\
\hline Brachyteciaceae & Scleropodium purum & $\begin{array}{l}\text { Europa: Córsega, Alemanha; } \\
\text { África: Ilhas Canárias }\end{array}$ \\
\hline Sphagnaceae & Sphagnum angustifolium & EUA \\
\hline Sphagnaceae & Sphagnum auriculatum & República Tcheca, França, Noruega, Alemanha. \\
\hline Sphagnaceae & Sphagnum capillifolium & $\begin{array}{l}\text { Canadá, EUA, Colômbia, Venezuela, Áustria, Suécia, } \\
\text { Alemanha, China. }\end{array}$ \\
\hline Sphagnaceae & Sphagnum magellanicum & $\begin{array}{l}\text { América do Norte: Canadá, EUA; } \\
\text { América Central: Costa Rica, Honduras, Panamá; } \\
\text { América do Sul: Argentina, Bolívia, Brasil, Chile, } \\
\text { Colômbia, Equador, Peru, Suriname, Venezuela; } \\
\text { Europa: Suécia, Alemanha; } \\
\text { Ásia: China. }\end{array}$ \\
\hline Sphagnaceae & Sphagnum papillosum & $\begin{array}{l}\text { Canadá, EUA, Áustria, República Tcheca, Finlândia, } \\
\text { Grã Bretanha, Suécia, China. }\end{array}$ \\
\hline Pottiaceae & Tortula muralis & $\begin{array}{l}\text { EUA, Chile, Paraguai, Grã Bretanha, Irlanda, Polônia, } \\
\text { Suíça, Alemanha, Ilhas Canárias, África do Sul, Israel, } \\
\text { Rússia, Austrália. }\end{array}$ \\
\hline
\end{tabular}

(10) MISSOURI BOTANICAL GARDEN - W3MOST, 2003 
Quadro 11 - Líquens Bioindicadores de Poluição Atmosférica

\begin{tabular}{|c|c|}
\hline Espécie & Espécie \\
\hline Alectoria sarmentosa & Parmelia sulcata \\
\hline Anaptychia ciliares & Physcia adscendens \\
\hline Bryoria spp & Pseudovernia furfuracea \\
\hline Canomaculina pilosa $*$ & Punctella subrudecta $*$ \\
\hline Crataria nivalis & Ramalina duriaei \\
\hline Evernia spp & Ramalina farinaceae * \\
\hline Flavoparmelia caperata & Ramalina lacera \\
\hline Flavopunctelia flaventior & Ramalina maciformis \\
\hline Hypogymnia physodes & Umbilicaria spp \\
\hline Laobaria pulmonaria & Usnea amblyoclada * \\
\hline Losallia pustulata & Usnea hirta \\
\hline Parmelia caperata & Xanthoria parietina $*$ \\
\hline Parmelia consperca & Xanthoria spp \\
\hline
\end{tabular}

* Registros de ocorrência em território brasileiro, segundo Checklist of Lichens and Lichenicolous Fungi (2004) 
Nos itens seguintes, encontram-se descrições sucintas dos bioindicadores mais freqüentemente utilizados, conforme levantamento efetuado na presente revisão sistemática. Encontram-se, ainda, as descrições das espécies que possuem registros de ocorrência no Brasil e espécies que se adaptam ao cultivo em território brasileiro.

\subsubsection{Gêneros e espécies vegetais encontrados com maior freqüência nesta investigação, utilizados no Brasil e no mundo}

Dentre as espécies vegetais utilizadas como bioindicadores de poluição atmosférica nos 126 estudos analisados, destacaram-se, pela freqüência de uso, as que seguem:

\subsubsection{Angiospermas}

Nicotiana tabacum (tabaco)

Do total de estudos levantados por esta revisão da literatura, em sua fase final, foram selecionados 19 artigos (15,0 \%) sobre o uso de Nicotiana tabacum como bioindicador vegetal de poluição atmosférica por $\mathrm{O}_{3}$.

Espécie pertencente à Família Solanaceae, com ampla distribuição geográfica, natural ou introduzida, na América Central, EUA e Brasil (MISSOURI - W3T, 2004). Possui hábitos arbustivos, com importância econômica na produção do tabaco.

Como bioindicador vegetal, foi verificado que é freqüentemente utilizada em estudos científicos voltados para a avaliação da ação oxidante do $\mathrm{O}_{3}$ troposférico sobre o vegetal, existindo cultivares da espécie reconhecidamente sensíveis à ação oxidante do $\mathrm{O}_{3}$ e outros cultivares tolerantes, destacando-se Bel-W3 e KK6/5, como cultivares sensíveis; e, K63 e Bel-B, como cultivares resistentes (GODZIK, 1997; SAITNIS; KARANDINOS, 2002). 
Para a verificação de danos provocados pelo poluente sobre plantas desta espécie, alguns autores utilizaram-se de métodos que estimam, visualmente, a porcentagem de área foliar com lesões como clorose, necrose e bronzeamento. Estes métodos foram apresentados na forma de índice de injúrias visíveis ou índice de danos foliares (SAITANIS; RIGAKARANDINOS; KARANDINOS, 2001; SAITANIS; KARANDINOS, 2002; VERGÉ; CHAPUIS; DELPOUX, 2002).

Além de danos foliares, alguns autores verificaram alterações metabólicas, como concentrações de clorofila a e b e proporções entre elas, bem como parâmetros de crescimento. Constataram que o poluente pode antecipar o envelhecimento de plantas expostas e reduzir a atividade fotossintética, com conseqüências para o crescimento e produção de biomassa vegetal (BLUM et al., 1997; BRÜMELIS et al., 1999; GODZIK, 1997; PEÑUELAS et al., 1999; SAITANIS; RIGA-KARANDINOS; KARANDINOS, 2001).

As conseqüências danosas em plantas dessa espécie observadas em estudos experimentais são importantes para demonstrar a perda do valor comercial, quando expostas a condições ambientais desfavoráveis em relação ao $\mathrm{O}_{3}$ (SAITANIS; RIGA-KARANDINOS; KARANDINOS, 2001).

Vale, também, ressaltar que o $\mathrm{O}_{3}$ troposférico não fica restrito à atmosfera urbana, tendo em vista que os seus precursores, hidrocarbonetos voláteis e $\mathrm{NO}_{2}$, são extremamente móveis, podendo ocorrer a formação do $\mathrm{O}_{3}$ “ruim” mesmo em áreas rurais, distantes de fontes de emissão de poluentes atmosféricos (KUEHLER; FLAGLER, 1999).

Vergé, Chapuis e Delpoux (2002) verificaram variações de sensibilidade ao $\mathrm{O}_{3}$ dentro de uma mesma população do cultivar Bel-W3 da espécie Nicotiana tabacum, conhecido pela sua alta sensibilidade ao poluente. Os autores ressaltam a necessidade de cuidados no uso de bioindicadores vegetais, sugerindo a verificação antecipada de eventual 
variação de sensibilidade e mecanismos de adaptação a fatores ambientais, principalmente em bioindicadores passivos, utilizados in situ.

Domingos, Klumpp e Klumpp (1998), utilizando a espécie Nicotiana tabacum em monitoramento ativo efetuado na região do complexo industrial de Cubatão, região Sudeste do Brasil, verificaram a ocorrência de danos foliares ozônio-induzidos em plantas expostas a emissões provenientes de refinaria de petróleo e indústrias petroquímicas instaladas nas proximidades de um dos pontos de monitoramento. Verificaram uma tendência na intensificação das injúrias foliares durante a primavera e outono. Ressaltaram a ocorrência de concentrações fitotóxicas de $\mathrm{O}_{3}$ em toda a região da Serra do Mar, podendo representar um risco às espécies vegetais sensíveis componentes da formação florestal ali existente.

\section{Tillandsia}

Na presente revisão da literatura, foram verificados 13 (10,3 \%) estudos sobre o uso do gênero Tillandsia como bioindicador de metais pesados e VOCs.

Gênero de plantas pertencentes à Família Bromeliaceae, sub-família Tillandsioidiaceae, que inclui principalmente espécies epífitas, ou seja, que se apóiam em troncos e galhos de árvores, ou na fiação aérea, em ambientes urbanos. Possuem crescimento lento e alta capacidade de obter água e nutrientes da atmosfera por meio dos tricomas, que são estruturas típicas da epiderme destinadas a esta finalidade. Suas raízes possuem a função exclusiva de fixação (BRIGHIGNA et al., 2002; PIGNATA et al., 2002).

O gênero Tillandsia possui ampla distribuição na América Central e do Sul, com inúmeras espécies apresentando alta tolerância ao estresse hídrico (PIGNATA et al., 2002; MISSOURI - W3T, 2004). 


\section{Tillandsia usneoide}

A espécie Tillandsia usneoide, também conhecida como barba-de-velho, possui a capacidade de se adaptar a ambientes secos e quentes, graças às escamas que revestem caules e folhas, protegendo os estômatos do ressecamento (AMADO FILHO et al., 2002). A espécie demonstrou ser um eficiente acumulador de Hg, segundo estudos de Calasans e Malm (1997), Malm et al. (1998) e Amado Filho et al. (2002).

Calasans e Malm (1997) utilizaram essa espécie para avaliar o potencial de risco ocupacional e de contaminação ambiental por Hg, em ambiente industrial na cidade do Rio de Janeiro, Brasil. Os autores verificaram incrementos nas concentrações do poluente, em função do tempo de exposição da planta ao ambiente estudado, sendo verificado que 20 dias foram suficientes para que se registrassem concentrações bastante elevadas. Atribuíram os resultados à capacidade de bioacumulação do vegetal estudado. Os autores recomendaram o uso dessa espécie em estudos de biomonitoramento, em virtude de sua alta resistência a condições de estresse ambiental, somada à capacidade de bioacumulação.

Malm et al. (1998), em estudo voltado à avaliação de concentrações de Hg atmosférico e sua dispersão na área urbana da cidade de Alta Floresta, centro comercial de ouro no Amazonas, Brasil, utilizaram a bromélia Tillandsia usneoides. Verificaram maiores concentrações de Hg nas plantas colocadas próximas aos exaustores das oficinas e no interior delas. Verificaram a ocorrência de valores três vezes mais altos durante as estações secas, provavelmente refletindo a redução da produção e comercialização de ouro nas estações chuvosas. Também poderia refletir a relação existente entre o Hg com material particulado, que é mais importante durante as estações secas, quando a quantidade de poeira no ar é maior.

Amado Filho et al. (2002) utilizaram T. usneoides em ensaios de biomonitoramento ativo em ambiente interno de uma indústria na cidade do Rio de Janeiro, Brasil, onde ocorriam emissões contendo Hg. Visavam identificar se o metal era absorvido e retido pela 
planta, ou se permanecia apenas nas suas estruturas externas. Os autores verificaram concentrações mais elevadas de Hg na superfície do caule e escamas, quando comparadas com células da epiderme. Nas células do sistema vascular, verificaram a total ausência do metal. Concluíram que a extensa área superficial existente em plantas dessa espécie foi a principal responsável pela adsorção das partículas e pela absorção de vapor de água contendo Hg, além de Cl e provavelmente Zn.

\section{Tillandsia capillaris}

A espécie Tillandsia capillaris respondeu adequadamente aos ensaios de biomonitoramento da qualidade do ar conduzido em diversas localidades da Argentina, permitindo o mapeamento da distribuição de metais pesados na região de estudo. Considerando as concentrações de metais nas plantas e as respostas fisiológicas em amostras da espécie, os autores recomendaram o seu uso no biomonitoramento da qualidade do ar (PIGNATA et al., 2002).

\section{Tillandsia caput-medusae e Tillandsia bulbosa}

A espécie Tillandsia caput-medusae demonstrou eficiência na acumulação de metais presentes no ar, em áreas poluídas de San José da Costa Rica, sendo indicada ao biomonitoramento da qualidade do ar (BRIGHIGNA et al., 1997).

Brighigna et al. (2002) empregaram as bromélias Tillandsia bulbosa e Tillandsia caput-medusae no biomonitoramento ativo de PAHs presentes na atmosfera de Florença, Itália, em área sujeita a tráfego contínuo de veículos. Não verificaram a ocorrência de sintomas aparentes de estresse nas amostras submetidas à ação dos poluentes. Entretanto, verificaram o acúmulo progressivo dos hidrocarbonetos analisados em tecidos das plantas. A espécie Tillandsia bulbosa demonstrou ser mais eficiente na retenção de PAHs que a espécie 
Tillandsia caput-medusae. Recomendaram o uso de plantas do gênero Tillandsia nos países da América Latina e Sudeste dos EUA, onde crescem de forma espontânea.

\section{Tradescantia}

Na presente revisão da literatura, foram identificados 9 (7,1 \%) estudos sobre o uso da espécie Tradescantia pallida cv purpurea e dos clones híbridos Tradescantia 02 e Tradescantia 4430, como bioindicadores de $\mathrm{CO}, \mathrm{SO}_{2}, \mathrm{NO}_{2}$ e MP-10.

Gênero pertencente à Família Commeliaceae, com cerca de 70 espécies, além de diversos híbridos, distribuídos em toda a América (MISSOURI - W3T, 2004). Possui hábitos herbáceos, sendo algumas espécies, como a T. pallida, freqüentemente utilizadas no paisagismo de jardins urbanos.

Os clones híbridos Tradescantia 02 e Tradescantia 4430 e, mais recentemente, a espécie Tradescantia pallida cv purpurea, têm sido utilizados desde a década de 60 do século XX, na avaliação dos efeitos genotóxicos de poluentes atmosféricos e demais substâncias tóxicas. O uso do gênero em estudos genotóxicos deve-se à característica genética favorável, por ser constituído de apenas seis pares de cromossomos, facilmente observáveis em todas as células da planta, de acordo com Rodrigues et al. (1997).

Ferreira et al. (2003) submeteram plantas de Tradescantia a ambientes de intenso tráfego de veículos, na cidade de São Paulo, Brasil, com o intuito de verificar uma possível associação entre os níveis de poluição atmosférica e taxas de mutação detectáveis pelo ensaio “Tradescantia stamem hair mutation” (Trad-SHM). O bioensaio Trad-SHM quantifica as ocorrências de mutações mitóticas em pelos estaminais, observáveis pela alteração da cor azul padrão das células, para a cor rosa (FERREIRA et al., 2000; MA, 1999; RODRIGUES et al., 1997). Pela correlação linear entre freqüências de mutação e concentrações diárias e mensais de material particulado, foi possível confirmar uma associação positiva dos eventos de 
mutação com este poluente. Os autores ressaltaram a necessidade de se dedicar especial atenção a este componente da poluição atmosférica, recomendando que iniciativas de investigação sobre a problemática apresentada sejam incentivadas, com o intuito de se promover medidas de controle de poluição e de proteção à população exposta.

Ferreira et al. (2000) verificaram o potencial mutagênico de emissões atmosféricas de um incinerador de resíduos sólidos de serviços de saúde, durante 5 meses, na cidade de São Paulo, Brasil, em plantas de Tradescantia clone 4430. As plantas foram distribuídas em três diferentes distâncias da fonte, tomando-se por base estudos anteriores sobre a pluma de dispersão das emissões atmosféricas do referido incinerador. Utilizando-se do protocolo padrão de ensaio Trad-SHM, verificaram a existência de correlação positiva entre os níveis de mutação e as contribuições espaciais das emissões do incinerador. Os autores entenderam que, embora respostas positivas em sistemas vegetais não possam ser aplicadas diretamente em seres humanos, os resultados encontrados servem de alerta sobre o perigo potencial à saúde da população exposta.

Batalha et al. (1999) submeteram amostras de plantas da espécie Tradescantia pallida, coletadas em área exposta a intenso tráfego de veículos, na cidade de São Paulo, Brasil, a soluções preparadas com MP-10 e água destilada, em concentrações de 15 e 30 mg/L. Verificaram a ocorrência de eventos de mutagenicidade pelo bioensaio "Tradescantia micronucleus” (Trad-MCN). Este bioensaio quantifica eventos de mutação, detectáveis pela formação de micronúcleos em células-mãe de grãos de pólen, em decorrência da fragmentação do cromossomo, durante a fase tétrade da divisão meiótica, em níveis superiores aos considerados espontâneos (ALVES et al., 2003; GUIMARÃES et al., 2000). Obtiveram resultados positivos no ensaio efetuado. Os autores consideraram a espécie apropriada para ensaios de mutagenicidade e alertaram para o fato de moradores de centros urbanos estarem cronicamente expostos a substâncias genotóxicas, presentes na atmosfera. 
Tradescantia clone 4430 foi utilizada em experimentação ativa, conduzida em áreas sob influência de emissões atmosféricas veiculares contendo $\mathrm{SO}_{2}, \mathrm{NOx}$ e $\mathrm{O}_{3}$, sendo verificadas alterações anatômicas importantes. Os autores consideraram que os resultados obtidos refletiram, de forma indireta, o efeito da poluição no crescimento da planta, considerando que as primeiras alterações devem ocorrer no balanço hídrico e na taxa fotossintética de plantas expostas a condições de estresse ambiental (ALVES et al., 2001).

Tibouchina pulchra (manacá-da-serra)

Espécie arbórea pioneira, pertencente à Família Melastomataceae, freqüente em formações secundárias da Floresta Pluvial da Encosta Atlântica, com registros de ocorrência natural nos Estados de São Paulo e Paraná, sendo facilmente observada nos períodos de floração, pela cor rosa das flores, que se destacam em meio à densa massa verde da mata (BASE DE DADOS TROPICAL, 2004).

Foram identificados 6 (4,7\%) estudos sobre o uso da espécie como bioindicador de metais pesados, óxidos de enxofre e fluoretos, na presente revisão da literatura.

A espécie Tibouchina pulchra Cogn. possui uma especial capacidade em acumular metais pesados, S e F, tendo sido verificadas alterações bioquímicas e fisiológicas importantes, sem se ter registros de sintomas visíveis na planta. É considerada espécie tolerante, devido a sua alta capacidade de sobrevivência em ambientes poluídos (DOMINGOS; KLUMPP; KLUMPP, 1998; KLUMPP et al., 1998; MORAES et al., 2002).

Klumpp et al. (1998) avaliaram o comportamento de mudas da espécie Tibouchina pulchra na região do complexo industrial de Cubatão, Sudeste do Brasil, na presença de emissões combinadas de material particulado e compostos de F, S e N. Verificaram que, apesar dos grandes acúmulos de diversos elementos químicos, a espécie Tibouchina pulchra não mostrou evidências de danos sofridos pela ação dos poluentes. Entretanto, por análises 
bioquímicas dos conteúdos das folhas, observaram que alterações significativas no metabolismo das plantas expostas ocorreram, provavelmente, em virtude da ação dos poluentes atmosféricos. Consideraram que os poluentes emitidos pelo complexo industrial de Cubatão representam um alto risco para a estabilidade do ecossistema afetado.

Domingos, Klumpp e Klumpp (1998) conduziram ensaios de biomonitoramento ativo e passivo na área de influência do complexo industrial de Cubatão, região Sudeste do Brasil, com o intuito de avaliar os impactos submetidos à parcela da Mata Atlântica presente na área, bem como eventuais mecanismos de resistência em espécies vegetais nativas. Utilizaram plântulas e árvores adultas de várias espécies, dentre elas Tibouchina pulchra. Os autores puderam verificar elevadas concentrações de F em folhas de plantas expostas, da referida espécie, tanto em material proveniente do monitoramento passivo (plantas adultas), como do monitoramento ativo (plântulas). Concentrações elevadas de Mn, S e N também foram registradas em plântulas de Tibouchina pulchra, após 28 dias de exposição nos locais de poluição mais intensa. Os autores destacaram a provável ausência de mecanismo seletivo na assimilação de elementos tóxicos por esta espécie, atribuindo a ela uma certa sensibilidade à poluição do ar, pelo incremento na atividade da enzima peroxidase. Os autores, ainda, registraram variações nas concentrações de ascorbato e elevado poder tampão no extrato foliar de plantas expostas dessa mesma espécie, o que foi considerado um provável mecanismo de proteção ao estresse provocado pelos poluentes atmosféricos. Consideraram a espécie tolerante à poluição do ar, evidenciada pela sua capacidade de sobrevivência em locais altamente poluídos.

Klumpp et al. (2000) analisaram os efeitos da poluição do ar e da contaminação do solo em plântulas e indivíduos adultos de Tibouchina pulchra, também na região do complexo industrial de Cubatão, Brasil. Tomaram por base alterações de parâmetros bioquímicos indicadores de estresse: atividade da enzima peroxidase, pH e poder tampão do extrato de 
folhas, conteúdo de ascorbato, dentre outros. Também avaliaram parâmetros de crescimento da parte aérea e sistema radicular de plantas expostas. Verificaram variações significativas nos parâmetros analisados, tanto em plântulas, como em árvores adultas, revelando a ocorrência de distúrbios metabólicos decorrentes das condições atmosféricas e do solo, a que se encontravam submetidas. Apesar das alterações observadas, a espécie foi capaz de sobreviver em ambientes altamente poluídos, sendo recomendada pelos autores para estudos de estimativas de taxas de poluição e no mapeamento da qualidade do ar.

Moraes, Delitti e Moraes (2000) submeteram plantas jovens de T. pulchra às condições de poluição atmosférica decorrentes da atividade industrial de Cubatão, Brasil, durante os meses de pior qualidade do ar na área, em três locais com diferentes níveis de poluição. Buscaram avaliar o efeito de poluentes aéreos sobre o crescimento e sobre parâmetros bioquímicos, como a fotossíntese líquida, em plantas expostas. A redução nas taxas de fotossíntese líquida só foi registrada em uma das áreas experimentais, enquanto que variações nas taxas de crescimento foram registradas em duas dessas áreas, sendo que em uma delas apresentando episódios fitotóxicos por PAN e $\mathrm{O}_{3}$. Plantas expostas a emissões atmosféricas contendo $\mathrm{F}$, provenientes de indústria de fertilizantes, apresentaram grande acúmulo do elemento nos tecidos foliares. Apesar de não apresentarem danos visíveis, os resultados indicaram que as plantas estiveram submetidas a situações de forte estresse ambiental, devido às condições locais desfavoráveis em relação aos poluentes atmosféricos.

\subsubsection{Coniferofitas}

\section{Pinus sylvestris}

Pertence à Família Pinaceae, ocorrendo de forma natural na Europa e Ásia Temperada, de acordo com Lorenzi et al. (2003). Existem registros de coletas da espécie nos 
EUA, México, Rússia e Nova Zelândia, conforme Missouri Botanical Garden - W3T (2004). Não há registros de cultivo da espécie em território brasileiro.

O uso da espécie esteve associado, nesta revisão da literatura, ao biomonitoramento de metais, $\mathrm{NOx}, \mathrm{SO}_{2}$ e hidrocarbonetos presentes na atmosfera de áreas poluídas, em um total de 5 (4,0 \%) estudos realizados em países europeus.

Kurczynska et al. (1997) avaliaram a influência da poluição atmosférica sobre a composição química foliar e sobre a anatomia do caule de indivíduos da espécie Pinus sylvestris, em amostras de acículas coletadas em árvores de florestas sob a influência de atividades poluidoras na região de Varsóvia, Polônia. Análises anatômicas de amostras do caule revelaram o decréscimo no número de células do câmbio, do xilema e floema, bem como a formação de falsos anéis de crescimento. Também registraram concentrações de metais acima do normal nas acículas. Os autores atribuíram os resultados aos poluentes atmosféricos, que se apresentaram em excesso para $\mathrm{Cd}$ e $\mathrm{Pb}$ e em concentrações tóxicas para Zn e Cr.

Grodzinska-Jurksak e Szarek-Lukaszeuska (1999) avaliaram as concentrações de S e $\mathrm{N}$ em acículas de $P$. sylvestris e de outra conífera, cujos exemplares estiveram expostos a contínuas emissões atmosféricas industriais contendo $\mathrm{SO}_{2}$ e $\mathrm{NO}_{2}$ e metais, em várias regiões da Polônia. Também avaliaram os danos causados pelos poluentes à cera epicuticular de revestimento das acículas. Verificaram que, tanto as concentrações de $\mathrm{S}$ e $\mathrm{N}$ nas acículas, como os danos físicos à cera epicuticular, apresentaram, na maioria dos casos, relação positiva com as concentrações atmosféricas dos dois gases ácidos.

Holoubek et al. (2000) efetuaram coleta de acículas de exemplares de P. sylvestris expostos a emissões atmosféricas industriais, contendo PAHs e outros poluentes orgânicos, provenientes de praguicidas e de fontes distantes, na República Tcheca. Com base nos 
resultados obtidos, os autores concluíram que a vegetação pode ser utilizada para indicar as variações espaciais de emissões de poluentes orgânicos.

Keymeulen et al. (2001) verificaram concentrações de benzeno, tolueno, etilbenzeno e xileno (BETEX) na atmosfera e em acículas de um ano de exemplares de Pinus sylvestris, situados ao longo de rodovias, nas proximidades de indústrias e na zona rural da Bélgica, Hungria e Lituânia. Verificaram concentrações abaixo ou próximas do limite de detecção do benzeno nas amostras de acículas coletadas. As demais substâncias também registraram baixas concentrações. Na atmosfera, as maiores concentrações foram registradas nas proximidades de postos de abastecimento de combustível e em rodovias da Lituânia, enquanto que os menores valores foram registrados na Hungria. As condições ambientais, em relação aos poluentes considerados, de todos os locais de amostragem, influenciaram as concentrações encontradas nas acículas.

Rautio e Huttunen (2003) verificaram o impacto de emissões industriais contendo S e metais, sobre a composição química foliar, em indivíduos de $P$. sylvestris, buscando enfatizar as contribuições do material particulado acumulado na superfície das acículas, sobre as concentrações foliares totais dos elementos analisados. Utilizaram, para tanto, de método destinado à analise nutricional foliar. Pelos resultados observados, os autores concluíram que o emprego de técnica utilizada não é recomendado para estudos de biomonitoramento, tendo em vista a necessidade de avaliação do conteúdo total, e não apenas as concentrações internas das folhas.

Picea abies (pinheiro-da-noruega)

Espécie pertencente à Família Pinaceae, habitando as regiões montanhosas da Europa e da Ásia. No Brasil, pode ser encontrada na região Sul, em maiores altitudes 
(LORENZI et al., 2003). De acordo com Missouri Botanical Garden - W3T (2004), existem registros de coleta na China e na América do Norte.

A espécie esteve associada, segundo os levantamentos efetuados nesta revisão sistemática da literatura, ao biomonitoramento de $\mathrm{SO}_{2}, \mathrm{O}_{3}$ e metais pesados, em 4 (3,2 \%) estudos.

Kubizñáková (2001) verificou que as concentrações de S em amostras de chuva coletadas no interior de uma floresta de Picea abies, na República Tcheca eram de 2 a 9 vezes superiores aos valores encontrados em amostras de chuva coletadas em áreas abertas. Destacaram o papel das copas das árvores na interceptação do poluente atmosférico, que são lavados pela chuva e acumulados no solo, contribuindo para a sua acidificação.

Trimbacher e Weis (1999) verificaram a ocorrência de correlação significativa entre a qualidade da cera que reveste a superfície das acículas de Picea abies e o conteúdo de S nas amostras de acículas coletadas nas proximidades de fontes emissoras de $\mathrm{SO}_{2}$. Atribuíram o fato ao excesso de S ambiental. Consideraram o uso da cera epicuticular em acículas da espécie como um bioindicador adequado na detecção de poluentes atmosféricos.

Erosões nas ceras que recobrem a superfície das acículas de Picea abies também foram registradas por Grodzinska-Jurczak e Szarek-Lukaszewska (1999), em florestas da Polônia fortemente atingidas por emissões atmosféricas industriais contendo $\mathrm{SO}_{2}$ e $\mathrm{NO}_{2}$. Verificaram que os danos físicos à cera epicuticular eram mais freqüentes e severos, quanto maiores as concentrações de S na planta, que acima de $1268 \mathrm{mg} \mathrm{x} \mathrm{g}^{-1}$ já provocaram injúrias.

Pinus pinea (pinheiro litorâneo)

Espécie pertencente à Família Pinaceae, habitando o Sul da Europa (LORENZI et al., 2003). Segundo a base de dados W3T, do Missouri Botanical Garden (2004), existem 
registros de coleta da espécie nos EUA e Nova Zelândia.Verificou-se o uso da espécie em 2 $(1,6 \%)$ do total de estudos analisados.

Alaimo et al. (2000) consideraram as acículas de pinheiros como um interessante indicador de poluição atmosférica, nas regiões onde ocorrem naturalmente, ou onde possam ser cultivadas, tendo em vista a facilidade de sua identificação por pessoas não familiarizadas com aspectos botânicos. Estes autores verificaram que, dos elementos encontrados em acículas de Pinus pinea, $\mathrm{Pb}, \mathrm{Br}, \mathrm{Sb}, \mathrm{Cu}$ e $\mathrm{Zn}$ estavam associados com atividades antropogênicas.

Alessio et al. (2002) analisaram a composição isotópica de C em acículas de Pinus pinea situadas em um parque urbano, na cidade de Roma, Itália. Verificaram uma forte influência dos combustíveis fósseis na composição foliar de C. Pelos resultados alcançados, os autores recomendam o uso de rádio-carbono para a quantificação de contribuições antrópicas, nas concentrações ambientais do poluente.

\subsubsection{Musgos}

Pleurozium schreberi e Hylocomium splendens, Família Hylocomiaceae

Segundo consta na base de dados W3T, do Missouri Botanical Garden (2004), existem registros de ocorrência da espécie Pleurozium schreberi na América, Europa e Ásia. Foram encontrados, por esta revisão da literatura, 10 (7,9 \%) trabalhos científicos utilizando as espécies, juntas ou separadamente, no biomonitoramento de metais pesados e material particulado, realizados em países europeus.

A espécie de musgo Hylocomium splendens foi registrada na América do Norte,

Caribe, Europa, África e Ásia, de acordo com a base de dados W3T, do Missouri Botanical Garden (2004). Dos trabalhos científicos analisados por esta revisão sistemática da literatura, foram registrados 7 (5,5\%) estudos utilizando a espécie, associada a metais pesados e MP. 
Mankovská (1997) utilizou as duas espécies de musgo, visando avaliar as concentrações de metais pesados em amostras correspondentes a 3 anos de deposições atmosféricas. O autor também avaliou a concentração dos mesmos metais em amostras de húmus proveniente da mesma área de estudo. As amostras de húmus apresentaram maiores concentrações dos elementos analisados, exceto para $\mathrm{Cd}$, quando comparadas com as amostras de musgos. O autor considerou que, tanto musgos, como húmus são bioindicadores sensíveis à poluição atmosférica de origem antropogênica.

Berg e Steinnes (1997a) utilizaram a espécie de musgo Hylocomium splendens em biomonitoramento passivo de deposições atmosféricas, pela análise de 53 elementos químicos, em todo o território da Noruega. Vários elementos encontrados nas amostras coletadas foram atribuídos à contaminação por poeira do solo, enquanto que outros (Pb, Mo, Sn, Ag, Sb, V, Cd, Tl, Bi, e As) foram associados ao transporte por massas de ar de longas distâncias, de fontes localizadas em outras partes da Europa. Foram registradas maiores concentrações nas amostras coletadas na região Sul daquele país. Compararam os resultados com estudos similares realizados em 1977, 1985 e 1990, verificando reduções da ordem de 50\% nos elementos associados ao transporte de longas distâncias, entre 1977 e 1990 . O mesmo não foi verificado entre 1990 e 1995, época da realização do estudo em questão.

Halleraker et al. (1998) utilizaram Pleurozium schreberi e Hylocomium splendens para documentar as características químicas ambientais do Ártico Europeu, como parte de projeto colaborativo de mapeamento ecogeoquímico, tendo como objetivo avaliar as variações entre as espécies, comparar as variações entre as amostras, nos locais onde as duas espécies foram encontradas e, avaliar a aplicabilidade de calibração inter-específica para a área de estudo. Dos 36 elementos estudados, 20 apresentaram variações significativas entre as duas espécies de musgos. Em 10 dos 36 elementos, verificaram variações regionais entre as 
espécies. Os autores encontraram dificuldade em desenvolver método de calibração interespecífica, para a área de estudo.

Rosman, Ly e Steinnes (1998) coletaram amostras de musgos da espécie Hylocomium splendens em diferentes partes da Noruega, representativas de variações de níveis de exposição por $\mathrm{Pb}$ e de condições meteorológicas, visando avaliar a composição isotópica e os diferentes tipos de contribuições do poluente, ocorridas de 1974 a 1994 naquele país. As variações encontradas refletiram as mudanças ocorridas em decorrência do controle de emissões estacionárias e móveis, no período considerado. Foram, ainda, identificadas fontes remotas do poluente, provenientes de países europeus vizinhos.

Brümelis et al. (1999) utilizaram a espécie Hylocomium splendens em biomonitoramento passivo, nas proximidades de uma indústria siderúrgica na Lituânia, visando obter estimativas de deposições de Zn, Pb e Cu. Os autores efetuaram análises de concentrações de Zn nas paredes celulares, no interior das células e no meio intra-celular, visando determinar a parcela assimilável e os níveis tóxicos do elemento, causadores de alterações metabólicas. Verificaram que as amostras coletadas junto à fonte de emissão apresentaram níveis tóxicos de Zn intra-celular.

Ceburnis, Steinnes e Kvietkus (1999) analisaram as concentrações de metais (Cd, Cr, $\mathrm{Cu}, \mathrm{Fe}, \mathrm{Mn}, \mathrm{Ni}, \mathrm{V}$ e Zn) em amostras de musgos das espécies Pleurozium schreberi e Hylocomium splendens, comparando, ainda, com as concentrações dos mesmos metais em amostras de deposições atmosféricas, em diversas localidades da Lituânia. Os autores puderam verificar que a principal fonte dos elementos analisados foi a atmosfera, sendo que o solo também se apresentou como uma importante fonte de contribuição para Fe, $\mathrm{Cr}$ e Ni. Os autores evidenciaram a necessidade de se efetuar testes de calibração para as diferentes regiões geográficas, caso se pretenda converter concentrações de metais em musgos, para concentrações atmosféricas dos elementos considerados. 
Wappelhorst et al. (2000) utilizaram duas espécies de musgos, sendo uma delas a espécie Pleurozium schreberi, em projeto de biomonitoramento regional de deposições atmosféricas, compreendendo Alemanha, Polônia e República Tcheca. Os autores verificaram as concentrações de 37 elementos químicos, em amostras coletadas de musgos, cujos resultados serviram como base para a determinação dos elementos presentes em deposições atmosféricas, causadores de doenças em seres humanos. Correlacionaram as concentrações dos elementos nos musgos com o mapeamento de internações hospitalares, incluindo registros de óbitos, no período considerado. Verificaram a existência de correlação entre as concentrações de Ce, Fe, Ga e Ge nos musgos e a ocorrência de doenças do sistema respiratório. Também verificaram correlação entre concentrações de Th e doenças cardíacas.

Grodzinska e Szarek-Lukaszewska (2001) avaliaram a capacidade da espécie de musgo Pleurozium schreberi em acumular metais pesados, concluindo pela validade no uso da espécie para avaliar a contaminação ambiental, em áreas poluídas da Polônia.

Szarek-Lukaszewska; Grodzinska; Braniewski (2002) verificaram reduções significativas nas concentrações de Pb e Fe em amostras de Pleurozium schreberi, entre 1975 e 1995, na região da Floresta Niepolomice. Atribuíram os resultados à redução de emissões de poluentes atmosféricos e aos avanços tecnológicos nas indústrias da região.

\section{Hipnum cupressiforme, Família Hypnaceae}

De acordo com a base de dados W3T, do Missouri Botanical Garden (2004), existem registros de ocorrência da espécie na América, Europa, Ásia, África e Oceania. Foram encontrados, em nossa pesquisa, 5 (4,0 \%) estudos utilizando a presente espécie, na avaliação de metais pesados e hidrocarbonetos presentes na atmosfera.

Loppi e Bonini (2000) utilizaram a espécie Hipnum cupressiforme e uma espécie de líquen no biomonitoramento passivo de emissões atmosféricas de fontes naturais (gêiseres), 
no Monte Amiata, Itália. Comparam os resultados obtidos na área de estudo, com trabalhos realizados em área não poluída, verificando acumulação de $\mathrm{Hg}$, S e Al. Os autores consideraram, pelos resultados obtidos, que musgos e líquens prestam-se à análise de deposições de As, Cd, Cu, Mo e S.

Holoubeck et al. (2000) utilizaram a espécie Hipnum cupressiforme como bioindicador de hidrocarbonetos aromáticos policíclicos (PAHs) de duas fontes industriais, na República Tcheca, entre 1988 e 1994. Os autores verificaram que as concentrações de PAHs nos musgos coletados próximos às fontes de emissão eram cerca de 5 vezes superiores, em relação à área-controle. Também verificaram variações nos tipos de hidrocarbonetos acumulados, entre a área-controle e às fontes de emissão industrial. As maiores concentrações de PAHs registradas foram de amostras coletadas junto às fontes industriais, sendo observado reduções com o seu distanciamento.

Genoni, Parco, Santagostino (2000) utilizaram musgos da espécie Hipnum cupressiforme no biomonitoramento passivo de metais pesados provenientes de emissões atmosféricas de termoelétrica, na província de Milão, Itália. Consideraram uma área de aproximadamente 50 km2, no entorno da fonte de emissão. A bioacumulação de metais nos musgos foi obtida após correção dos valores relativos a contaminações do solo, de modo a se obter um padrão de deposição. Os maiores valores foram encontrados em musgos coletados junto à fonte de emissão, reduzindo rapidamente com a distância. Os valores médios obtidos foram da ordem de 5,5 vezes maiores para V e 3,3 vezes para Ni, em relação ao controle.

Fernández e Carballeira (2000) compararam as concentrações de Hg em musgos da espécie Hipnum cupressiforme, nativos e transplantados, nas proximidades de uma indústria cloro-alcali, na Espanha. Os resultados obtidos demonstraram que o uso de musgos transplantados pode ser utilizado com segurança em locais com escassez de musgos nativos. 
Apresentam ainda a vantagem de permitir a padronização do material experimental, em termos fisiológicos e de capacidade de bioacumulação.

Figueira, Sérgio e Souza (2002) utilizaram duas espécies de musgos, sendo uma delas Hipnum cupressiforme, em estudo conduzido em todo o território português, visando verificar os níveis de deposição de $\mathrm{Cd}, \mathrm{Cr}, \mathrm{Cu}, \mathrm{Fe}, \mathrm{Mn}, \mathrm{Ni}, \mathrm{Pb}, \mathrm{Zn}$. Compararam as concentrações observadas nos musgos, com as concentrações de amostras de solo, empregando o método de análise estatística de multivariáveis. Também avaliaram correlações das concentrações de metais nos musgos, com variáveis ambientais e antropogênicas. As maiores concentrações de $\mathrm{Cu}, \mathrm{Pb}$ e $\mathrm{Zn}$ foram registradas em localidades densamente povoadas e com alto consumo de gasolina. As concentrações elevadas de Fe e Cr foram associadas à ressuspensão de partículas do solo. Os autores consideraram que a análise de bioacumulação em musgos foi um método válido para estudos de deposições atmosféricas no território português.

\subsubsection{Líquens}

Líquens foram utilizados em estudos conduzidos em localidades do Canadá, Estados Unidos, Groenlândia, Finlândia, Itália, Grécia e Israel, como bioacumuladores de metais pesados presentes na atmosfera.

Nimis, Andreussi e Pittao (2001) consideraram a necessidade de relacionar a idade da amostra coletada de líquen com as concentrações de metais observadas. Freqüentemente, líquens são coletados in toto, sem que se faça distinção entre partes jovens e velhas do talo, prática que pode conduzir a erros de interpretação, visto que as partes centrais, mais velhas, estiveram expostas ao poluente por um período maior de tempo. Os autores sugeriram o uso apenas das partes periféricas de líquens, já que a idade do talo não pode ser facilmente avaliada, em função das variações de condições climáticas e ecológicas. 
Líquens de diversas espécies foram utilizados nos estudos analisados por esta revisão da literatura, que verificaram a ação do $\mathrm{SO}_{2}$ sobre estes organismos, na Polônia, Finlândia, Bélgica, Holanda, Grécia, Canadá e Israel.

Geebelen e Hoffmann (2001) consideraram as emissões de $\mathrm{SO}_{2}$ como principais responsáveis pela presença ou ausência de líquens epífitas na região de Flanders, Bélgica, ainda que reduções significativas do poluente tenham sido observadas na região, nas últimas décadas do século XX.

Giordani, Brunialti e Alleteo (2002) verificaram correlação positiva entre a redução no número de espécies de líquens e concentrações ambientais de $\mathrm{SO}_{2}$ e $\mathrm{NOx}$, na região de estudo, indicando que os dois poluentes foram os principais responsáveis pela perda registrada de biodiversidade.

\section{Gênero Parmelia}

Quanto aos líquens desse gênero, foram registrados 7 (5,5 \%) estudos utilizando líquens do gênero Parmelia, em nossa pesquisa.

\section{Parmelia caperata}

Loppi et al. (1998) analisaram as concentrações de S, As, B, Hg em amostras de líquens da espécie Parmelia caperata, coletadas nas áreas de influência de 4 usinas geotermoelétricas, em Travale-Radicondoli, Itália Central. A espécie revelou ser um eficiente acumulador dos metais analisados. Os autores, também, avaliaram o índice de pureza atmosférica (IAP) pela observação visual da presença da espécie, utilizando grade de amostragem. Os menores valores de IAP foram registrados nas proximidades das usinas, até uma distância de 500 metros, sendo observado o incremento nos valores de IAP com o distanciamento das fontes. Os resultados obtidos sugeriram aos autores que as emissões 
gasosas provenientes das usinas geo-termoelétricas foram responsáveis pelas variações nos valores de IAP encontrados.

Loppi et al. (2000) utilizaram a mesma espécie em ensaios de biomonitoramento passivo de emissões atmosféricas produzidas por um incinerador de resíduos sólidos, com um ano de atividade, em Paggibonsi, Itália. Efetuaram a análise das concentrações de metais (Al, $\mathrm{Cd}, \mathrm{Cr}, \mathrm{Cu}, \mathrm{Fe}, \mathrm{Hg}, \mathrm{Pb}$, e $\mathrm{Zn}$ ) em amostras de líquens, representativas de um ano de crescimento, coletadas a distâncias de 50 a 1100 metros do incinerador, além das coletas em duas áreas-controle, situadas a mais de 3,5 km da fonte de emissão. Não foram verificadas variações significativas para as concentrações de $\mathrm{Al}, \mathrm{Cu}$ e $\mathrm{Hg}$, entre as amostras de líquens coletadas na área de influência do incinerador e aquelas coletadas nas áreas-controle. Concentrações de Cd foram altas em toda a área de estudo, com valores entre 2 a 9 vezes superiores aos das áreas-controle. Para o Cr, foram encontrados valores 15 vezes maiores que nas áreas controle, enquanto que, para o Zn, foram registrados valores 2 vezes superiores que as amostras das áreas controle. Os autores consideraram que os resultados obtidos foram indicativos de que o incinerador foi o responsável pela poluição do ar verificada no local.

Nimis, Andreussi e Pittao (2001) analisaram as concentrações de metais (Al, As, Ba, Be, Cd, Cr, Cu, Fe, Hg, Mn, Ni, Pb, Sc, Te, V, Zn) em amostras de P. caperata e de outra espécie de líquen, utilizando partes jovens e mais velhas das colônias amostradas, em estudo de biomonitoramento passivo efetuado no Nordeste da Itália. Os autores buscaram avaliar variações intra e inter-específicas nas capacidades de bioacumulação. As partes centrais ou mais velhas apresentaram as maiores concentrações dos metais analisados, nas duas espécies utilizadas. Nas partes jovens do talo, os autores verificaram que as duas espécies não apresentaram afinidades pelos mesmos metais, sendo que $P$. caperata apresentou maior afinidade por Zn e Cd. Os autores recomendaram o uso apenas de partes jovens dos talos, em estudos dessa natureza. 


\section{Parmelia sulcata}

Loppi e Bonini (2000) analisaram concentrações de metais (Al, As, B, Cd, Cu, Fe, Hg, Mo, Pb, Sb, Zn) e S em amostras da espécie Parmelia sulcata sob influência de emissões de fontes termais e veiculares, na região do Monte Amiata, Itália. A espécie mostrou-se boa acumuladora dos metais analisados.

Loppi e Bonini (2000) avaliaram as contribuições de vapores de fontes geotérmicas naturais para a contaminação da atmosfera local, por meio da análise de concentração de elementos-traço em amostras de Parmelia sulcata e de uma espécie de musgo, coletadas em dois locais do Monte Amiata, Itália. Os autores consideraram, pelos resultados obtidos, que musgos e líquens podem ser utilizados, indiferentemente, com acumuladores de As, Cd, Cu, Mo e S presentes em emissões atmosféricas.

\section{Parmelia consparca}

Grasso et al. (1999) analisaram concentrações de 27 elementos químicos em amostras de líquens da espécie, coletadas em troncos e rochas, no Monte Etna e Ilha Vulcano, Itália.Verificaram que a composição química dos líquens refletia as contribuições vulcânicas por materiais particulados, revelando as diferentes tendências geoquímicas das duas fontes vulcânicas estudadas.

\section{Gênero Usnea}

Foram registrados 6 (4,8 \%) estudos sobre o uso de líquens do gênero Usnea como bioindicador de poluentes atmosféricos diversos, em nossa pesquisa.

Carignan, Simonetti e Gariépy (2002) avaliaram a composição isotópica de Pb em amostras de líquens do gênero Usnea, coletadas nas proximidades de minas de extração de Pb, nas províncias do Canadá, e no Vale de St. Lawrey, EUA. Líquens provenientes da região 
Nordeste da América do Norte apresentaram Pb característico de atividades antropogênicas. As variações isotópicas foram interpretadas como resultados de uma mistura entre fontes industriais dos EUA e Canadá. Os resultaram permitiram aos autores o primeiro mapeamento da distribuição isotópica de Pb no Nordeste da América do Norte.

\section{Usnea amblyoclada}

Carreras e Pignata (2001) avaliaram parâmetros bioquímicos e de crescimento em amostras transplantadas da espécie Usnea amblyoclada, submetidas à ação de poluentes atmosféricos contidos em emissões veiculares e industriais, na cidade de Córdoba, Argentina. Os autores verificaram que as altas concentrações de clorofila e dos demais parâmetros analisados coincidiam com a elevação dos níveis de partículas suspensas, hidrocarbonetos, $\mathrm{O}_{3}$

e $\mathrm{H}_{2} \mathrm{~S}$ atmosféricos, de acordo com registros efetuados durante todo o período do experimento. As alterações bioquímicas foram verificadas durante o período de inverno, sendo as mesmas relacionadas com ocorrências meteorológicas desfavoráveis, já que as concentrações dos contaminantes analisados não excederam os níveis máximos admitidos.

Clair et al. (2002) avaliaram concentrações de $\mathrm{Cu}$ em amostras das espécies $U$. amblyoclada e $U$. hirta coletadas junto a indústrias metalúrgicas, em várias localidades dos EUA. Verificaram que as espécies utilizadas refletiam, em sua composição química interna, as concentrações ambientais de $\mathrm{Cu}$.

\section{Gênero Xanthoria}

Foram registrados 5 (3,9 \%) estudos utilizando o referido gênero de líquen, como bioindicador de metais pesados em emissões atmosféricas, em nossa pesquisa.

Loppi (2001) analisou as concentrações de Hg e outros elementos-traço em amostras de líquen do gênero Xanthoria, coletados nas proximidades de uma usina geo-termoelétrica, 
em Bagnore, Itália, verificando correlação linear entre os valores de concentrações de Hg nos líquens e nos ambientes expostos a emissões naturais e da usina.

\section{Xanthoria parietina}

Grasso et al. (1999) analisaram concentrações de 27 elementos químicos provenientes de emissões vulcânicas, em amostras de líquens presentes em troncos e rochas, no Monte Etna e Ilha Vulcano, Itália, obtendo resultados significativos sobre a importância de líquens no monitoramento da qualidade do ar com influência de emissões vulcânicas.

Nimis, Andreussi e Pittao (2001) analisaram concentrações de metais (Al, As, Ba, Be, Cd, Cr, Cu, Fe, Hg, Mn, Ni, Pb, Sc, Te, V, Zn), nas partes jovens (periféricas) e mais antigas (centro) de colônias de líquens da referida espécie, em 10 localidades da região Nordeste da Itália. Os resultados revelaram variações intra e inter-específicas e maiores concentrações nas partes velhas dos talos.

Nimis et al.(2000) analisaram as concentrações de metais ( Al, As, Ba, Cd, Cr, Fe, Hg, Mn, Ni, Pb, V, Zn) em amostras de líquens coletadas nas áreas de influência das fontes de emissões atmosféricas consideradas (industrial, veicular e agrícola), na região de Veneto, Itália, mapeando áreas em situação de risco, recomendando, ali, o uso de instrumentos.

Scerbo et al. (1999) analisaram as concentrações de metais (As, Cd, Cr, Ni, Pb, V, Zn, Hg) em amostras de líquens expostos a emissões atmosféricas industriais e ao tráfego de veículos. Também verificaram o Índice de Pureza Atmosférica (IAP), tomando como base a freqüência da espécie, considerada sensível ao poluente, na área de estudo. 


\subsection{2 - Gêneros e espécies vegetais encontrados com menor freqüência nesta} investigação, com ocorrência natural ou cultivada no Brasil

Outras espécies vegetais foram registradas com menor freqüência nos 126 estudos analisados, as quais são aqui destacadas em função de sua ocorrência natural ou cultivada no território brasileiro.

\subsubsection{Angiospermas}

Possuem ocorrência natural no Brasil as seguintes espécies pertencentes à Divisão Angiosperma:

Cecropia glaziovii (embaúba vermelha)

Espécie arbórea da Família Cecropiaceae, sendo sua presença registrada na Mata Atlântica, Estado de São Paulo (BASE DE DADOS TROPICAL, 2004).

Utilizada por Domingos, Klumpp e Klumpp (1998), no biomonitoramento passivo de emissões atmosféricas contendo metais pesados, na região do Complexo Industrial de Cubatão, SP, Brasil. Não registraram evidências da espécie em acumular metais.

Foi também utilizada por Klumpp et al. (1998), no biomonitoramento passivo de poluentes industriais contendo fluoretos, NOx , compostos de S e metais pesados, sendo registrados acúmulos significativos de $\mathrm{N}$ em folhas de plantas expostas.

Gallesia gorazema (G. integrifollia; pau d’alho)

Espécie arbórea pertencente à família Phytolacaceae, com registros de sua ocorrência na Mata Atlântica, no Espírito Santo e em matas ciliares, no Estado de São Paulo (BASE DE DADOS TROPICAL, 2004). 
Foi verificado, na presente revisão sistemática da literatura, o uso da espécie por Silva et al. (2000), no biomonitoramento ativo de chuva simulada contendo flúor. Plântulas e mudas expostas apresentaram necroses e cloroses foliares e altas concentrações de flúor.

\section{Genipa americana (genipapo)}

Espécie arbórea pertencente à Família Rubiaceae, tendo sido registrada sua ocorrência na Mata Atlântica, nos Estados da Bahia e Espírito Santo (BASE DE DADOS TROPICAL, 2004).

Silva et al. (2000) utilizaram plântulas e mudas de diversas espécies arbóreas nativas no Parque Estadual do Rio Doce, em Minas Gerais, Brasil, para avaliar o efeito do F presente em chuva simulada, em ensaios de biomonitoramento ativo. A espécie Genipa americana mostrou-se mais resistente à ação do poluente, apresentando os menores índices de injúrias foliares, bem como a menor taxa de acúmulo diário de F.

\section{Euterpe edulis (juçara)}

Espécie de palmeira, da Família Arecaceae, típica da floresta pluvial da encosta atlântica e da floresta latifoliada semidecídua da Bacia do Paraná, ocorrendo desde o Sul da Bahia, até o Rio Grande do Sul, e nos Estados de Minas Gerais, Goiás, Mato Grosso do Sul, São Paulo e Paraná (BASE DE DADOS TROPICAL, 2004; LORENZI, 1992).

Utilizada por Bulbovas (2000), que registrou variações na germinação de sementes e injúrias foliares de plantas expostas a poluentes industriais do Complexo Industrial de Cubatão, SP, Brasil. 


\section{Joanesia princeps (cotieira)}

Espécie arbórea da Família Euphorbiaceae, com registros de sua ocorrência na Mata Atlântica, nos Estados da Bahia e Espírito Santo, de acordo com a Base de Dados Tropical (2004).

Foi utilizada por Silva et al. (2000), no biomonitoramento ativo de chuva simulada contendo F, quando foi avaliada a reação da planta ao poluente, pela ocorrência de cloroses e necroses foliares, taxa de acumulação de F e de crescimento. As mudas da espécie mostraram níveis moderados de danos, enquanto que as plântulas foram as mais afetadas, em relação às cinco espécies estudadas. A ausência de alterações nas taxas de crescimento e as baixas taxas de acúmulo diário do F pela espécie foram atribuídos ao tempo insuficiente de duração do experimento.

\section{Miconia}

Gênero pertencente à Família Melatomataceae, com ampla distribuição no território brasileiro, segundo a Base de Dados Tropical (2004).

Três espécies do gênero Miconia foram registradas em estudos científicos envolvendo espécies vegetais e poluentes atmosféricos industriais, provenientes do Complexo Industrial de Cubatão, Sudeste do Estado de São Paulo, Brasil: M. cabucu, M. pyrifolia e M. cinnamomifolia (DOMINGOS, KLUMPP e KLUMPP, 1998; POMPÉIA, 1997).

\section{Peltophorum dubium (canafístula)}

Espécie arbórea, pertencente à Família Caesalpinaceae, com registros de sua ocorrência em matas ciliares, pela Base de Dados Tropical (2004) e na floresta latifoliada semidecídua, da Bahia até o Paraná, segundo Lorenzi (1992). 
Utilizada por Silva et al. (2000) no biomonitoramento ativo de chuva simulada contendo flúor. Esta espécie apresentou as maiores concentrações de F, em mudas expostas a 10 dias de tratamento, porém com respostas moderadas verificadas nos danos foliares, pela ação do poluente.

\section{Psidium}

Gênero pertencente à Família Myrtaceae, sendo registrado o uso de duas espécies arbóreas como bioindicadores de poluição atmosférica, na presente revisão sistemática da literatura: P. guayava e P.cattleyanum. A primeira espécie apresenta ampla distribuição geográfica, desde os cerrados até formações florestais densas, sendo considerada uma espécie pan-tropical (BASE DE DADOS TROPICAL, 2004; MORAES et al., 2002).

As duas espécies P. guayava e P.cattleyanum foram utilizadas em estudos de biomonitoramento ativo, apresentando alta capacidade em acumular S e F. Também apresentaram injúrias foliares e alterações significativas no metabolismo de antioxidantes e no crescimento vegetativo, quando expostas a emissões atmosféricas do complexo industrial de Cubatão, Sudeste do Estado de São Paulo, Brasil, de acordo com Klumpp et al. (1998) e Moraes et al. (2002).

Moraes et al. (2002) avaliaram o comportamento das espécies frutíferas, dentre elas, Psidim guayava e Psidium cattlyianum, em monitoramento ativo e em condições de campo, visando avaliar as espécies como possíveis bioindicadores tropicais de poluição atmosférica. Os experimentos foram conduzidos na região do complexo industrial de Cubatão, Sudeste do Brasil, na presença de emissões combinadas de material particulado e compostos de F, S e N. As duas espécies do gênero Psidium mostraram maior capacidade de acumulação de $\mathrm{S}$ que a espécie Tibouchina pulchra, analisada por Klumpp et al (1998), na mesma área de estudo. O acúmulo de $\mathrm{N}$ nos tecidos foliares de plantas expostas, foi considerado pelos autores como 
decorrentes da absorção de poluentes nitrogenados, bem como pela presença de $\mathrm{SO}_{2}$ e $\mathrm{O}_{3}$ no ambiente, que induzem ao aumento de níveis de $\mathrm{N}$ nas folhas.

Klumpp et al. (1998) avaliaram também o comportamento de mudas das espécies, Psidim guayava e Psidium cattleyanum nessa mesma área de estudo. Verificaram que as duas espécies do gênero Psidium apresentaram apenas leves cloroses internervais. Entretanto, por análises bioquímicas dos conteúdos das folhas, observaram que alterações significativas no metabolismo das plantas expostas ocorreram por ação dos poluentes atmosféricos. Consideraram que os poluentes emitidos pelo complexo industrial de Cubatão representam um alto risco para a estabilidade do ecossistema afetado.

Ainda que a maioria dos estudos analisados não tenha sido desenvolvida no Brasil, com espécies vegetais da flora nacional, muitas das espécies utilizadas podem ser cultivadas nas condições climáticas e ecológicas locais, destacando-se:

\section{Gladiollus}

Gênero pertencente a Família Iridaceae, de hábitos herbáceos e registros de ocorrência na América Central, Europa, Oriente Médio e África (FLORA MESOAMERICA, 2004). Verificou-se o uso de híbridos do gênero por Domingos, Klumpp e Klumpp (1998), como bioindicador da ação do flúor, presente nas emissões atmosféricas do Complexo Industrial de Cubatão, Sudeste do Estado de São Paulo, Brasil.

\section{Hemerocalis}

Gênero pertencente à Família Liliaceae, com hábitos herbáceos e registros de ocorrência na Ásia Temperada, Sudeste da Europa e cultivada em diversas regiões do globo (FLORA MESOAMERICA, 2004). 
Como no gênero anterior, foram utilizados híbridos, por Domingos, Klumpp e Klumpp (1998), como bioindicadores da ação do flúor presente em emissões atmosféricas do Complexo Industrial de Cubatão, Sudeste do Estado de São Paulo, Brasil.

Domingos, Klumpp e Klumpp (1998) avaliaram a ação do flúor em plantas híbridas de Gladiollus e Hemerocalis em ensaios de monitoramento ativo conduzidos em áreas sob influência de emissões atmosféricas provenientes do complexo industrial de Cubatão, na região Sudeste do Brasil. Nas plantas híbridas de Gladiollus e Hemerocalis foram registradas manchas necróticas típicas da ação de fluoretos gasosos, além de concentrações elevadas de F. O forte impacto da ação do F sobre a vegetação analisada foi evidenciado pela comparação dos resultados obtidos, com fotografias de híbridos de Gladiollus e Hemerocolis submetidos a níveis máximos permitidos do poluente, em experimento conduzido na Europa.

\section{Mangifera indica (mangueira)}

Espécie arbórea pertencente à Família Anarcadeaceae, com registros de ocorrência em toda a América e Ásia (MISSOURI - W3T, 2004).

Lima, Fernandes e Fawcett (2000) avaliaram o comportamento da espécie frutífera Mangifera indica em monitoramento passivo, com exposição de plantas dessa espécie a emissões atmosféricas de indústrias petroquímicas contendo $\mathrm{SO}_{2}$, $\mathrm{NOx}$ e $\mathrm{O}_{3}$, do Pólo Petroquímico de Camaçari, na região Nordeste do Brasil. Considerando-se as altas concentrações de ácido ascórbico (AA) registradas, os autores puderam afirmar que $M$. indica é uma espécie resistente à ação dos poluentes atmosféricos analisados. O ácido ascórbico é um anti-oxidante natural em plantas e o aumento de concentrações de AA em folhas de vegetais expostos reflete a capacidade de reação a processos oxidativos gerados por estresse ambiental. Os autores sugerem o uso da espécie no mapeamento de áreas atingidas por poluição industrial. 


\section{Nerium oleander (espirradeira)}

Espécie arbustiva, pertencente à Família Apocynaceae, com registros de sua ocorrência em toda a América, além de países da África e Ásia (MISSOURI - W3T, 2004). Bastante utilizada para fins ornamentais, sendo comum nos jardins e calçadas das cidades brasileiras (LORENZI; SOUZA, 1995).

Akosy e Öztürk (1997), estudando a espécie arbustiva e ornamental Nerium oleander como bioindicadora de poluição por metais pesados, verificaram haver diferenças significativas nos resultados de concentração em folhas lavadas e não lavadas, sendo que os efeitos da lavagem das folhas foram mais pronunciados em amostras provenientes de áreas urbanas de Antalya, Turquia. Os altos conteúdos de metais pesados encontrados nas amostras de plantas e solos das áreas urbanas decorreram do intenso tráfego de veículos, considerado como principal fonte de contaminação por metais pesados, principalmente Pb. Por ocasião do estudo, a gasolina sem Pb era mais cara, sendo menos consumida pela população local.

\section{Phaseolus vulgaris (feijão)}

Espécie herbácea, pertencente a Família Fabaceae, produzida economicamente como base alimentar, na América Central e do Sul, Índias e Filipinas (MISSOURI - W3T, 2004). Registrou-se o uso da espécie em 2 estudos científicos levantados na presente revisão sistemática da literatura.

Lima, Fernandes e Fawcett (2000) utilizaram plântulas da espécie, em biomonitoramento ativo de poluentes atmosféricos $\left(\mathrm{SO}_{2}, \mathrm{NOx}\right.$ e $\left.\mathrm{O}_{3}\right)$, provenientes do Pólo Petroquímico de Camaçari, BA, Brasil, avaliando respostas fisiológicas de plantas expostas.

Lima, Fernandes e Fawcett (2000) avaliaram o comportamento da espécie em monitoramento ativo, com exposição de plantas dessa espécie a emissões atmosféricas de indústrias petroquímicas contendo $\mathrm{SO}_{2}, \mathrm{NOx}$ e $\mathrm{O}_{3}$, do Pólo Petroquímico de Camaçari, na 
região Nordeste do Brasil. Verificaram que Phaseolos vulgaris apresentou-se como espécie sensível, quando consideradas concentrações de ácido ascórbico nas folhas, bem como as reduções de área foliar apresentadas.

Kanoun et al. (2001), estudando alterações bioquímicas em plantas jovens e plântulas de Phaseolus vulgaris, sob a ação de níveis moderados de $\mathrm{O}_{3}$ induzido, verificaram boa correlação entre a produção de compostos fenólicos e o aparecimento de necroses nas folhas expostas ao poluente. Consideram que as interações entre planta e poluente são complexas e que o aparecimento de lesões pode ser decorrente de exposições agudas. Consideram os fenóis marcadores de fácil mensuração, de ambientes fitotóxicos pela presença de $\mathrm{O}_{3}$ troposférico.

\section{Urtica urens (urtiga)}

Espécie herbácea pertencente à Família Urticaceae, com registros de sua ocorrência em toda a América.

Domingos, Klumpp e Klumpp (1998) utilizaram esta e outras espécies tradicionalmente utilizadas como bioindicadores, em biomonitoramento ativo de poluentes secundários oxidantes (PAN, e $\mathrm{O}_{3}$ ), provenientes do Complexo Industrial de Cubatão, Sudeste do Estado de São Paulo, Brasil. Plantas expostas da espécie apresentaram dois tipos de injúrias visíveis, as quais foram atribuídas à ação desses poluentes. Os autores verificaram variações sazonais na intensidade dos danos foliares. Pelos resultados obtidos, os autores consideraram que o $\mathrm{O}_{3}$ e PAN estavam entre os principais poluentes causadores das perturbações observadas na Mata Atlântica, existente na área de estudo. 


\section{Taraxacum officinale (dente-de-leão)}

Espécie de hábitos herbáceos, pertencente à Família Asteraceae, apresentando ampla e abundante distribuição em diferentes latitudes e longitudes (NORMANDIN; KENNEDY; ZAYED, 1999). Registrou-se, nesta revisão sistemática da literatura, o uso da espécie em 2 (1,6 \%) estudos científicos.

Normandin, Kennedy e Zayed (1999) utilizaram plantas da espécie Taraxacum officinale, em biomonitoramento passivo de $\mathrm{Mn}$, presente em emissões veiculares geradas pela queima de gasolina contendo metilpentadieno manganês tricarbanil (MMT), no Canadá. Segundo verificado pelos autores, estudos sugerem que a combustão do MMT pode causar doenças deletérias em animais e em seres humanos. Coletaram amostras de solo e plantas da espécie, em três diferentes distâncias de uma auto-estrada, analisando os teores totais de Mn, Mg, Ca, Al, Fe, Zn, separadamente, em flores, caules, folhas e raízes das plantas coletadas. Os autores não verificaram correlação entre as concentrações de Mn nas diferentes partes da planta e as distâncias da auto-estrada, enquanto que, para o solo, puderam verificar as correlações esperadas. Os autores concluíram que a espécie T. officinale não se mostrou sensível à contaminação por Mn.

Keane et al. (2001) avaliaram a capacidade da espécie Taraxacum officinale em acumular metais pesados, em biomonitoramento passivo de ambientes sujeitos a emissões atmosféricas urbanas, de 29 localidades do meio-oeste dos Estados Unidos, apresentando diferentes fontes e níveis de poluição. Para tanto, efetuaram a análise química das folhas de plantas expostas, em relação a 8 metais (Cd, Cr, $\mathrm{Cu}, \mathrm{Ni}, \mathrm{Pb}, \mathrm{Zn})$. Também analisaram amostras de solo dos mesmos locais, relacionando as concentrações dos mesmos metais com as concentrações ambientais de PM-10, encontrando correlação significativa entre os dois fatores. Entretanto, não verificaram correlação consistente entre as concentrações ambientais e as concentrações nos tecidos das folhas da espécie estudada, dos metais considerados. Os 
autores concluíram que outros fatores ambientais, do solo e da planta afetaram a retenção dos metais, minimizando o potencial bioindicador da planta.

\section{Tagetes erecta (cravo-de-defunto)}

Espécie herbácea pertencente à Família Asteraceae, com distribuição natural nos países da América Central (FLORA MESOAMERICA, 2004). No Brasil, é utilizada no paisagismo e como flor de corte, destacando-se pelas cores amarela e alaranjada das flores, com abundante floração principalmente nos meses da primavera e verão (LORENZI; SOUZA, 1995).

Tonneijck, Berg e Jansen (2003) analisaram os efeitos do etileno atmosférico emitido por fontes industriais, em localidade da Holanda, sobre Tagetes erecta. As plantas localizadas muito próximas da fonte de emissão do poluente, na zona de influência de ventos dominantes, sofreram mais intensamente, apresentando sintomas de raquitismo, abortamento de botões florais e ausência total de floração. Consideraram como área de risco, pela ação do etileno, aquela circunscrita em um raio de 870 metros, a partir da fonte de emissão do poluente.

\section{Spondias dulcis (cajá-mirim)}

Espécie arbórea da Família Anarcadeaceae, com ocorrência na América Central, do Sul e em Madagascar (MISSOURI - W3T, 2004).

Registrou-se o uso da espécie por Silva et al. (2000), no biomonitoramento ativo de chuva simulada contendo flúor, mostrando-se uma das espécies mais sensíveis, do grupo estudado pelos pesquisadores, à ação do poluente. Pelos resultados obtidos, os pesquisadores consideraram a espécie como um potencial bioindicador da presença de F em ambientes sujeitos a emissões atmosféricas contendo gás fluorídrico e outros fluoretos gasosos. 


\subsubsection{Coniferofitas}

Das espécies pertencentes a esta Divisão e que, também, são utilizadas como bioindicadores de poluição atmosférica, relacionamos aquelas que possuem registro de adaptação ao território brasileiro:

Pinus taeda (pinheiro americano)

Pertence à Família Pinaceae, ocorrendo naturalmente na costa atlântica dos EUA e Golfo do México. No Brasil, adapta-se à região Sul do país, conforme relatado por Lorenzi et al. (2003).

Kuehler e Flagler (1999) utilizaram plântulas de Pinus taeda pertencentes a uma linhagem ozônio-sensíveis. As plântulas foram, então, protegidas com 2 produtos antioxidantes e submetidas a diferentes concentrações de $\mathrm{O}_{3}$. Analisaram parâmetros bioquímicos relacionados à ação do poluente sobre vegetais: fotossíntese líquida, condutância estomatal, concentrações de pigmentos no cloroplasto e concentração foliar total de N. Os resultados obtidos pelos autores revelaram que os produtos antioxidantes utilizados não ofereceram proteção efetiva, tendo em vista a ocorrência de danos foliares visíveis típicos da ação do $\mathrm{O}_{3}$ em espécies vegetais sensíveis ao poluente.

\section{Juniperus communis (junípero comum)}

Espécie pertencente à Família Cupressaceae, ocorrendo na América do Norte, Europa e Ásia. No Brasil, adapta-se às regiões de maiores altitudes, no Sul e Sudeste (LORENZI et al., 2003).

Ceburnis e Steinnes (2000) avaliaram as concentrações de metais em acículas dessa e de outra espécie de conífera, em 48 localidades da Lituânia, comparando, ainda, a viabilidade do uso de acículas de coníferas como bioindicador de deposições atmosféricas, em 
relação a 3 espécies de musgos freqüentemente utilizadas em biomonitoramento de poluição atmosférica. Verificaram baixa retenção de metais em acículas não lavadas da espécie Juniperus communis. As incertezas relativas a assimilações pela raiz ou pela parte aérea não permitiram avaliações quantitativas, sendo o uso de acículas da espécie recomendado pelos autores, como bioindicador qualitativo, ficando o seu uso no biomonitoramento quantitativo dos poluentes restrito às áreas próximas da fonte de emissão.

Cupressus sempervirens (cipreste do mediterrâneo)

Espécie pertencente à família Cupressaceae, habitando o Sul da Europa, Ilhas do Mediterrâneo, Ásia Menor e Rússia. No Brasil, adapta-se às regiões do Sul do país (LORENZI et al., 2003).

El-Hasan et al. (2002) utilizaram a casca de 36 exemplares dessa espécie, em biomonitoramento passivo da poluição atmosférica por metais pesados, de diferentes fontes antropogênicas e naturais na cidade de Amman, Jordânia. Emissões veiculares foram consideradas as principais fontes dos metais analisados. Os autores consideraram que o método pode ser utilizado com sucesso, em estudos de biomonitoramento da poluição atmosférica, principalmente para regiões áridas do planeta.

\subsubsection{Líquens}

Espécies de líquens menos freqüentemente utilizados como biondicadores de poluição atmosférica, porém com registros de ocorrência no território brasileiro, são, a seguir, relacionados:

\section{Punctella subrudecta}

Gonzalez e Pignata (1997) analisaram concentrações de S e alterações metabólicas em amostras transplantadas da espécie, submetidas a emissões atmosféricas de origem 
veicular, industrial e de termoelétrica, na cidade de Córdoba, Argentina. Os resultados confirmaram respostas químicas da espécie com as emissões atmosféricas industriais e da usina termoelétrica.

\section{Canomaculina pillosa}

González e Pignata (2000) analisaram concentrações de S e alterações metabólicas em amostras transplantadas de líquens, submetidas a emissões atmosféricas de fontes industriais, veiculares e de termoelétrica, na cidade de Córdoba, Argentina. Os autores verificaram alterações significativas em processos metabólicos nas amostras sob influência da atividade industrial.

\section{Ramalina farinaceae}

Riga-Karandinos e Karandinos (1998) analisaram concentrações de metais (Ca, Cd, $\mathrm{Cu}, \mathrm{Fe}, \mathrm{Mn}, \mathrm{Pb}, \mathrm{Zn}$ ) e S, bem como parâmetros bioquímicos em amostras desta e de mais duas outras espécies de líquens com ocorrência natural nas proximidades de uma termoelétrica a carvão, em Megapolis, Grécia, verificando variações significativas entre as espécies estudadas, em relação à capacidade de bioacumulação e nas alterações bioquímicas.

Verificamos, por esta revisão da literatura, que a busca por métodos complementares de avaliação da qualidade do ar, pelo uso de bioindicadores vegetais, vem ocorrendo em nível mundial. Consideramos que tal busca visa ampliar as possibilidades de diagnóstico precoce de situações de risco para populações humanas e aos ambientes naturais. Com a ajuda de sistemas vegetais padronizados, tornar-se-á possível a instalação mais acertada dos onerosos instrumentos destinados à quantificação dos poluentes atmosféricos, nas áreas afetadas. Neste sentido, os vegetais passarão a cumprir mais uma importante tarefa como auxiliares do desenvolvimento das sociedades humanas. 


\section{CONCLUSÕES}

\subsection{Sobre a Revisão Sistemática da Literatura}

A experiência obtida com esta investigação nos permite concluir que o uso da revisão sistemática da literatura requer no mínimo dois revisores com conhecimento prévio sobre o assunto pesquisado, além de disponibilidade de tempo para o cumprimento de todas as etapas previstas pela metodologia.

A aplicação dos testes de relevância possibilitou clareza na tomada de decisão quanto às inclusões ou exclusões dos resumos e artigos consultados, embora a seleção dos resumos poderia ter sido mais objetiva se, já no TR1, estivessem especificados os tipos de poluentes a serem incluídos neste estudo, o que havia sido estabelecido em nossos instrumentos apenas no TR2.

Assim, consideramos ter sido apropriado o uso da Revisão Sistemática da Literatura para o alcance dos objetivos pretendidos, na presente investigação. 


\subsection{Sobre o uso de bioindicadores vegetais em processos de poluição atmosférica}

Os resultados obtidos nesta investigação sobre o uso de bioindicadores vegetais em processos de poluição atmosférica revelaram a existência de uma grande diversidade de espécies utilizadas em ensaios de biomonitoramento, conduzidos por centros de pesquisa de diversos países.

Assim, concluímos, com esta revisão sistemática da literatura, que:

$>$ Muitos dos bioindicadores vegetais encontrados apresentavam-se associados a um determinado poluente atmosférico, destacando-se:

- $\quad$ Nicotiana tabacum como bioindicador de $\mathrm{O}_{3}$;

- Musgos como bioindicadores de metais e VOCs;

- Líquens como bioindicadores de metais, $\mathrm{SO}_{2}$ e $\mathrm{NOx}$;

- Bromélias do gênero Tillandsia como bioindicadores de metais e hidrocarbonetos;

- Variedades e clones híbridos de Tradescantia no biomonitoramento de agentes genotóxicos.

> Para as condições climáticas brasileiras, destacam-se as seguintes espécies com potencialidade de uso em sistemas de biomonitoramento:

- $\quad$ Nicotiana tabacum ou tabaco, no monitoramento de $\mathrm{O}_{3}$;

- Tradescantia pallida cv. pupurea ou trapoeraba roxa, no monitoramento de substâncias genotóxicas presentes em material particulado da atmosfera urbana;

- As espécies tropicais Tibouchina pulchra e Psidium guayava, manacá-da-serra e goiabeira, respectivamente, no monitoramento de F e S; 
- Bromélias do gênero Tillandsia, com ampla distribuição na América Latina, para o monitoramento de metais pesados e compostos orgânicos tóxicos;

- As espécies de musgos Hypnum cupressiforme, Pleurozium schreberi e Bryum argenteum, no monitoramento de metais pesados;

- As espécies de líquens Usnea amblyoclada, Xanthoria parietina, Punctella subrudecta, Canomaculina pilosa e Ramalina farinaceae, no monitoramento de metais e do S.

> Esta investigação também revelou o uso potencial de outras espécies como bioindicadores vegetais de poluição atmosférica, as quais consideramos merecerem estudos mais aprofundados, em virtude da amplitude de sua distribuição geográfica, por sua freqüente utilização, bem como por seu ciclo de vida curto e facilidade de reconhecimento pelo público leigo, destacando-se:

- Taraxacum officinale ou dente-de-leão;

- $\quad$ Nerium oleander ou espirradeira;

- $\quad$ Phaseolus vulgaris ou feijão comum;

- $\quad$ Urtica urens ou urtiga;

- $\quad$ Tagetes erecta ou cravo-de-defunto;

- Gladiollus ou palma-de-Santa-Rita e Hemerocallis;

- Mangifera indica ou mangueira que, apesar de ser espécie arbórea, cumpre outras funções sociais, pela produção de frutos comestíveis.

> Concluímos, ainda, que existe um amplo interesse, na academia, por estudos sobre bioindicadores vegetais de poluição atmosférica, considerando que os 126 trabalhos científicos, selecionados nesta investigação, foram desenvolvidos em 34 países, durante os quase 7 anos do período selecionado por este levantamento bibliográfico. 


\section{CONSIDERAÇÕES FINAIS}

A poluição atmosférica em ambientes urbanos tem recebido especial atenção dos centros de pesquisa e tecnologia de todo o mundo, desde as últimas décadas do século XX. Sensibilizados com as graves conseqüências à saúde humana e com os danos ao meio ambiente, ocorridos ao longo de décadas de intensa produção de bens, de consumo exacerbado e de descaso com as conseqüências para a saúde geral do planeta, líderes políticos e agentes públicos começam a sinalizar um interesse crescente na busca de mecanismos para reverter o processo de degradação ambiental e social instaladas, de forma global (BRILHANTE; CALDAS, 1999; MA, 1993).

Metais pesados, compostos orgânicos tóxicos, dióxido de enxofre, óxidos de nitrogênio, monóxido e dióxido de carbono, e fluoretos gasosos, dentre outros poluentes atmosféricos, são permanentemente lançados na baixa atmosfera por veículos particulares, meios de transporte coletivos e veículos de carga que trafegam nos centros urbanos; pelas indústrias, usinas termoelétricas e incineradores que, por sua vez, são também geradores de gases e materiais particulados, contendo substâncias prejudiciais ao conjunto de seres vivos que habitam cidades e ecossistemas naturais (BRAGA et al, 2002; FERREIRA et al., 2003; LOPPI et al., 2000).

Diante do panorama existente, melhorias vêm sendo alcançadas por meio de exigências e normas legais, tecnologias de produção mais limpas e pela conscientização social da necessidade de serem estabelecidos novos padrões de desenvolvimento, baseados na 
sustentabilidade ambiental e na garantia de acesso a condições saudáveis de vida para todos os habitantes do planeta.

No Brasil, o Ministério do Meio Ambiente promoveu, em novembro de 2003, a Conferência Nacional do Meio Ambiente, realizada em Brasília, Distrito Federal, visando ampliar o debate e a participação popular na formulação de propostas, bem como o estabelecimento de diretrizes de sustentabilidade para o país.

Baseada na implementação de políticas públicas de gestão ambiental, voltadas ao fortalecimento do Sistema Nacional de Meio Ambiente (SISNAMA), como agente principal no estabelecimento de um Brasil mais sustentável, a tese final da conferência, estabelece propostas para a política ambiental do Brasil.

No tópico “Meio Ambiente Urbano”, recomenda a adoção de sistemas de gestão e planejamento ambiental, que incentivem processos produtivos mais limpos e sustentáveis, buscando-se a redução ou eliminação de resíduos e da poluição atmosférica, em áreas urbanas e rurais. No sub-tópico “Mobilidade Urbana”, incentiva a adoção do transporte solidário e de sistemas de transporte que causem pouco impacto ao meio ambiente (CONFERÊNCIA, 2003).

A tese final desta Conferência também propõe a adoção de ações voltadas às mudanças climáticas globais, destacando-se:

- O incentivo ao desenvolvimento de tecnologias de custo acessível para o monitoramento contínuo e sistemático de condições climáticas;

- A ampliação do número de estações de monitoramento climático e de poluição;

- A implantação de laboratórios de referência destinados ao desenvolvimento de estudos sobre causas, efeitos, magnitude, vulnerabilidade, adaptação e mitigação dos efeitos das mudanças climáticas; 
Sobre as reduções de emissões, ainda no tópico relativo às mudanças climáticas, o mesmo documento propõe o estabelecimento de medidas voltadas à redução de emissões de gases do efeito estufa (GEEs), bem como de mecanismos voltadas ao seqüestro do carbono em excesso na atmosfera, decorrente de emissões atmosféricas de $\mathrm{CO}_{2}$, geradas pela queima de combustíveis fósseis e da biomassa vegetal.

Deve-se, aqui, considerar as qualidades dos sistemas já consagrados de monitoramento da qualidade do ar, utilizando-se metodologia baseada em análises físicoquímicas que, embora de eficácia comprovada, são limitadas pelos altos custos de implantação e manutenção, impossibilitando o seu emprego em larga escala, principalmente nos países em desenvolvimento, que sofrem, tanto ou mais, dos mesmos problemas de contaminação ambiental por poluentes atmosféricos (SUMITA et al., 2003; WAPPELHORST et al., 2000).

As diretrizes internacionais e nacionais anteriormente apresentadas, bem como os estudos levantados na presente investigação, revelam a importância do uso de bioindicadores vegetais em sistemas de monitoramento da qualidade ambiental urbana.

Em Ribeirão Preto, assim como nos demais municípios brasileiros submetidos à ação de poluentes atmosféricos, o desenvolvimento de sistemas de monitoramento do ar baseados no uso de bioindicadores vegetais poderá representar um avanço significativo na garantia da qualidade ambiental do município e região.

Ainda corroborando com Covello (1991); Leiss (1995); Gopalan (1999) e Klumpp et al. (2001), destacamos a necessidade de motivar a opinião pública, bem como os agentes públicos e privados, sobre os efeitos negativos da poluição, para que medidas corretivas possam ser implementadas e aceitas pela população envolvida. Nesse sentido, destacamos a responsabilidade, tanto de agências de controle ambiental, como dos agentes de produção; às primeiras, cabendo o papel de licenciador e fiscalizador dos processos produtivos, com base 
em normas e padrões aceitos pela legislação; aos agentes de produção, cabendo o compromisso de implementar sistemas de auto-monitoramento, para os quais a adoção de bioindicadores vegetais poderá ser um importante instrumento de diagnóstico precoce de situações de poluição ambiental não desejáveis para a saúde humana, ao lado de outras medidas a serem implementadas pelo setor industrial.

Ainda, ressaltamos o grande valor da participação social da comunidade envolvida, visando a institucionalização de processos de comunicação de risco ambiental, partindo tanto do setor público, quanto do privado.

Finalmente, consideramos oportuno que esforços sejam direcionados no sentido de se promover a instalação de uma rede de biomonitoramento da qualidade do ar no Estado de São Paulo, iniciando-se por um trabalho conjunto e coordenado entre universidades públicas, administrações municipais e agências estaduais de proteção ambiental.

As redes convencionais instaladas de monitoramento da qualidade do ar, além de todo o serviço atualmente prestado à comunidade na área ambiental, poderiam atuar de forma integrada à rede de biomonitoramento, dando suporte às observações efetuadas nos sistemas vegetais.

Tal iniciativa poderá servir como um importante instrumento de apoio à implantação de políticas públicas inovadoras, significando, ainda, um passo decisivo na universalização dos cuidados com os ambientes social e natural, promovendo e garantindo melhorias efetivas no padrão de qualidade de vida das sociedades atuais e futuras. 


\section{APÊNDICE A}

\section{TESTE DE RELEVÂNCIA 1 (TR1) \\ PARA INCLUSÃO DE ESTUDOS E PESQUISAS RELACIONADOS AO USO DE VEGETAÇÃO COMO BIOINDICADOR DE POLUIÇÃO ATMOSFÉRICA}

Identificação do Estudo/Pesquisa Autor(es):

Título:

Periódico:
Protocolo n. ${ }^{\circ}$

v.- $\quad$ n.- $\quad$ ano -

\begin{tabular}{|l|l|l|}
\hline $1 .^{\text {o }}$ Teste de Relevância & Sim & Não \\
\hline $\begin{array}{l}\text { 1. É um estudo descritivo observacional ou estudo } \\
\text { experimental e não uma revisão bibliográfica ou } \\
\text { editorial? }\end{array}$ & & \\
\hline $\begin{array}{l}\text { 2. Trata-se de trabalho publicado no período de } \\
\text { janeiro de } 1996 \text { a julho de } 2003 \text { ? }\end{array}$ & & \\
\hline $\begin{array}{l}\text { 3. É uma publicação de revista científica, dissertação ou } \\
\text { tese indexada em banco de dados nacionais ou } \\
\text { internacionais selecionados para esta investigação, cujo } \\
\text { texto encontra-se disponível na íntegra? }\end{array}$ & & \\
\hline $\begin{array}{l}\text { 4. É publicado em língua portuguesa, inglesa ou } \\
\text { espanhola? }\end{array}$ & & \\
\hline $\begin{array}{l}\text { 5. A investigação utiliza um ou mais bioindicadores } \\
\text { de espécies vegetais, liquens ou fungos como } \\
\text { testemunha da presença de poluentes atmosféricos? }\end{array}$ & & \\
\hline
\end{tabular}

1. avaliação do Trabalho (Resumo)

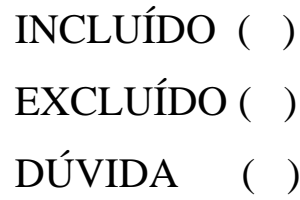

data: 


\section{APÊNDICE B}

\section{TESTE DE RELEVÂNCIA 2 (TR2) \\ PARA INCLUSÃO DE ESTUDOS E PESQUISAS RELACIONADOS AO USO DE VEGETAÇÃO COMO BIOINDICDOR DE POLUIÇÃO ATMOSFÉRICA}

Identificação do Estudo/Pesquisa Autor(es):

Título:

Periódico:
Protocolo n. ${ }^{\circ}$

V.- $\quad$ n.- $\quad$ ano -

\begin{tabular}{|l|l|l|}
\hline $2^{0}$ Teste de Relevância & Sim & Não \\
\hline $\begin{array}{l}\text { 1. A investigação analisa a ação, direta ou } \\
\text { indiretamente, de pelo menos um dos contaminantes } \\
\text { atmosféricos previamente selecionados: PTS, MP-10, } \\
\text { metais pesados, } \mathrm{SO}_{2} \text {, } \mathrm{NO}_{\mathrm{x}}, \mathrm{O}_{3} \text {, CO, VOCs, } \\
\text { hidrocarbonetos, } \mathrm{HF} \text { e demais fluoretos gasosos? } \\
\text { (mesmo quando não explicitados nominalmente, mas } \\
\text { depreendidos, considerando a fonte de poluição)? }\end{array}$ & & \\
\hline $\begin{array}{l}\text { 2. O estudo aponta para a presença de danos } \\
\text { identificáveis a olho nu em folhas, caule, flores ou } \\
\text { frutos? }\end{array}$ & & \\
\hline $\begin{array}{l}\text { 3. O estudo aponta para modificações anatômicas, } \\
\text { metabólicas, fisiológicas ou genéticas na planta? }\end{array}$ & & \\
\hline $\begin{array}{l}\text { 4. O estudo correlaciona alterações verificadas nos } \\
\text { vegetais com concentrações de poluentes }\end{array}$ & & \\
atmosféricos? & & \\
\hline $\begin{array}{l}\text { 5. Trata-se de vegetal com papel de bioindicador ou } \\
\text { bioacumulador? }\end{array}$ & & \\
\hline
\end{tabular}

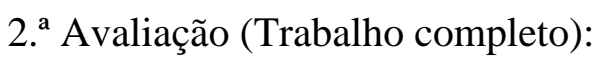

INCLUÍDO ( )

EXCLUÍDO ( )

Avaliador:

data: 


\section{REFERÊNCIAS}

ACETO, M.; ORNELlA A.; CONCA, R.; MALANDRINO, M.; MENTASTI, E.; SARZANINI, C. The use of mosses as environmental metal pollution indicators. Chemosphere, v.50, p. 333-342, 2003. Disponível em <http://www.sibi.usp.br/sibi/biblioteca/revista/selecao.php>. Acesso em: 17 jan. 2004.

ADAMO, P.; GIORDANO, S.; VINGIANI, S.; COBIANCHI, R.C.; VIOLANTE, P. Trace element accumulation by moss and lichen exposed in bags in the city of Napoles (Italy) Environmental Pollution, v.122, p.91-103, 2003. Disponível em <http://www.sibi.usp.br/sibi/biblioteca/revista/selecao.php>. Acesso em: 17 jan. 2004.

AFA. White paper: the forest effects of air pollution. American Forest, v.93, n.11/12, p.3744, 1987.

AKOSY, A.; ÖZTÜRK, M.A. Nerium oleander L. of lead and other heavy metal pollution in Mediterranean environments. The Science of the Total Environment, v.205, p.145-150, 1997. Disponível em < http://www.sibi.usp.br/sibi/biblioteca/revista/selecao.php>. Acesso em: 17 jan. 2004.

ALAIMO, M.G.; DONGARRÀ, G.; MELATI, M.R.; MONNA, F.; VARRICA, D. Recognition of environmental trace metal contamination using pine needles as bioindicators. The urban area of Palermo (Italy). Environmental Geology, v.39, n. 8, p.914-923, 2000. Disponível em <http://www.sibi.usp.br/sibi/biblioteca/revista/selecao.php>. Acesso em: 17 jan. 2004.

ALESSIO, M.; ANSELMI, S.; CONFORTO, L.; IMPROTA, S.; MANES, F.; MANFRA, L. Radiocarbon as a biomarker of urban pollution in leaves of evergreen species sampled in Rome and in rural areas Lazio-Central Italy). Atmospheric Environmental, v.36, p.54055416, 2002. Disponível em <http://www.sibi.usp.br/sibi/biblioteca/revista/selecao.php>. Acesso em: 17 jan. 2004.

ALVES, E.S.; GIUSTI, P.M.; DOMINGOS, M.; SALDIVA, P.H.N.; GUIMARÃES, E.T.; LOBO, D.J.A. Estudo anatômico foliar do clone híbrido 4430 de Tradescantia: alterações decorrentes da poluição aérea urbana. Rev. Brasil. Bot., São Paulo, v.24, n.4 (suplemento), p. 567-576, 2001. 
ALVES, E.S.; PEDROSO, A.N.V.; DOMINGOS, M.; GUIMARÃES, E.T.; SALDIVA, P.H.N. Biomonitoramento indoor do potencial mutagênico do ar em laboratórios e herbários do Instituto de Botânica por meio do bioensaio Trad-MCN. Hoehnea, v. 30, n. 2, p. 89-94, 2003.

AMADO FILHO, G.M.; ANDRADE, L.R.; FARINA, M.; MALM, O. Hg localization in Tillandsia usneoides L. (Bromeliaceae), an atmospheric biomonitor. Atmospheric Environment. v.36, p. 881-887, 2002. Disponível em <http://www.sibi.usp.br/sibi/biblioteca/revista/selecao.php>. Acesso em: 17 jan. 2004.

ANDREWS, J. E.; BRIMBLECOMBE, P.; JICKELLS, T.D. The atmosphere. In: An introduction to environmental chemistry. Oxford: Ed. Blackwell Science Ltd., 1996. Cap. 2, 12-45.

ARUTYUNYAN, R.M.; POGOSYAN, V.S.; SIMONYAN, E.H.; ATOYANTS, A.L.; DJIGARDJIAN, E.M. In situ monitoring of ambient air around the chloroprene rubber industrial plant using the Tracescantia-stamen-hair mutation assay. Mutation Research, v.426, p.117-120, $1999 . \quad$ Disponível em <http://www.sibi.usp.br/sibi/biblioteca/revista/selecao.php> $>$. Acesso em: 17 jan. 2004.

ATALLAH, N.A.; CASTRO, A. A. Revisões sistemáticas da literatura e metanálise: a melhor forma de evidência para tomada de decisão em saúde e a maneira mais rápida de atualização terapêutica. Diagnóstico \& Tratamento. v. 2, n. 2, p.12-15, 1997.

BACKIEL, A., HUNT, F.A. Acid rain and forest: an attempt to clear the air. American Forest, v.92, n.2, p.42-8, 1986.

BAIRD, C. A Química e a poluição do ar na troposfera. In: Química Ambiental. Tradução Maria Angeles Lobo Recio e Luiz Carlos Marques Carrera. Porto Alegre: Bookman, 2a edição, 2002. Cap. 3, p.107-193.

BASE DE DADOS TROPICAL (BDT). Banco de espécies da BDT. Disponível em <http://bdt.fat.org/species> Acesso em: 07 abr. 2004.

BATALHA, J.R.F.; GUIMARÃES, E.T.; LOBO, D.J.A.; LICHTENFELS, A.J.F.C.; DEUR, T.; CARVALHO, H.A.; ALVES, E.S.; DOMINGOS, M.; RODRIGUES, G.S.; SALDIVA, P.H.N. Exploring the clastogenic effects of air pollutants in São Paulo (Brazil) using the Tradescantia micronuclei assay. Mutation Research, v.426, p.229-232, 1999. Disponível em <http://www.sibi.usp.br/sibi/biblioteca/revista/selecao.php>. Acesso em: 17 jan. 2004.

BAUR, M.; LAUCHERT, U.; WILD, A. Biochemical indicators for novel forest decline in Spruce. Chemosphere, v. 36, n. 4-5, p. 865-870, 1998. Disponível em <http://www.sibi.usp.br/sibi/biblioteca/revista/selecao.php>. Acesso em: 17 jan. 2004. 
BEDNÁROVÁ, E. Situation in epicuticular waxes of birch (Betula pendula) leaves in airpolluted regions. Ekológica (Bratislava), v. 20, n. 3, p.284-291, 2001.

BERG, T.; STEINNES, E. Recent trends in atmospheric deposition of trace elements in Norway as evident from the 1995 moss survey. The Science of the Total Environment, v.208, p.197-206, 1997a. Disponível em

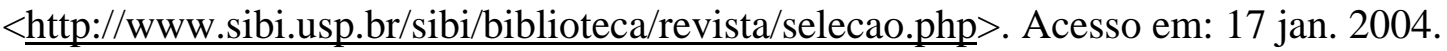

BERG, T.; STEINNES, E. Use of mosses (Hylocomium splendens and Pleurizium schreberi) as biomonitors of heavy metal deposition: from relative to absolute deposition values. Environmental Pollution, v.98, n.1, p.61-71, 1997b. Disponível em <http://www.sibi.usp.br/sibi/biblioteca/revista/selecao.php>. Acesso em: 17 jan. 2004.

BLUM, O.; BYTNEROWICZ, A.; MANNIG. W.; POPOVICHEVA, L.. Ambient tropospheric ozone in the Ukrainian Carpathian mountains and Kiev region: detection with passive samplers and bioindicator plants. Environmental Pollution, v. 98, n. 3, p.299 304, 1997. Disponível em < http://www.sibi.usp.br/sibi/biblioteca/revista/selecao.php>. Acesso em: 17 jan. 2004.

BÖHM, P.; WOLTERBEEK, H.; VERBURG, T.; MUSÍLEK, L. The use of tree bark for environmental pollution monitoring in the Czech Republic. Environmental Pollution, v.102, p.243-250, 1998. Disponível em < http://www.sibi.usp.br/sibi/biblioteca/revista/selecao.php>. Acesso em: 17 jan. 2004.

BORTIER, K.; DEKELVER,G.; DE TEMMERNAN, L.; CEULEMANS, R. Stem injection of Populus nigra with EDU to study ozone effects under fields conditions. Environmental Pollution, n.111, p.199-208, 2001. $\quad$ Disponível em

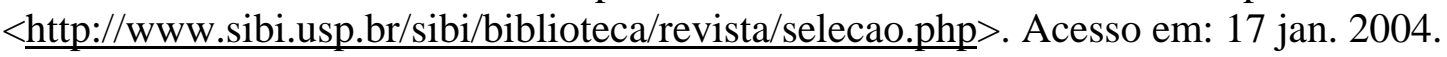

BOTKIN, D. B.; KELLER, E. A. Environmental Science: earth as a living planet. Third edition. USA: Ed. John Wiley and Sons., 2000. Cap. 14, p.299-305.

BRAGA, B.; HESPANHOL, I.; CONEJO, J.G.L.; BARROS, M.T.L. de; VERAS JUNIOR, M.S. O meio atmosférico. In: ___ Introdução a Engenharia Ambiental. São Paulo: Editora Printice Hall, 2002. Cap. 10, p.169-214.

BRASIL. Lei n. ${ }^{\circ} 6.983$ de 31/08/1981. Dispõe sobre a Política Nacional do Meio Ambiente, seus fins e mecanismos de formulação e aplicação e dá outras providências. Diário Oficial da União de 02/09/1981. Disponível em: <http://www.gov.br/port/CONAMA/index.cfm>. Acesso em 06 abr. 2004. 
BRASIL. Conselho Nacional do Meio Ambiente, CONAMA. Dispõe sobre procedimentos relativos a Estudos de Impacto Ambiental. Resolução n. ${ }^{\circ} 1$ de 23/01/1986. Diário Oficial da União, de 17/02/1986. Disponível em: <http://www.gov.br/port/CONAMA/index.cfm>. Acesso em: 06 abr. 2004.

BRASIL. Conselho Nacional do Meio Ambiente, CONAMA. Dispõe sobre os padrões da qualidade do ar. Resolução n. ${ }^{\circ} 3$ de 28/06/90. Diário Oficial da União de 22/08/1990. Disponível em <http://www.gov.br/port/CONAMA/index.cfm>. Acesso em: 06 abr. 2004.

BRESLOW, L. Da prevenção das doenças à promoção da saúde. JAMABrasil, v.3, n.7, 2252-2261, 1999.

BRIGHIGNA, L.; RAVANELLI, M.; MINELLI,A.; ERCOLI, L. The use of an epiphyte (Tillandsia caput-medusae morren) as bioindicator of air pollution in Costa Rica. The Science of Total Environment, 198, 175-180, 1997.

BRIGHIGNA, L.; PAPINI, A.; MOSTI, S.; CORNIA, A.; BOCCHINI, P.; GALLETTI, G. The use of tropical bromeliads (Tillandsia spp.) for monitoring atmospheric pollution in the town of Florence, Italy. Rev. Biol. Trop., v.50, n.2, p. 577-584, 2002. Disponível em $<$ http://www.sibi.usp.br/sibi/biblioteca/revista/selecao.php>. Acesso em: 17 jan. 2004.

BRILHANTE, M. O.; CALDAS, L. Q. de A. Gestão e Avaliação de Risco em Saúde Ambiental. Rio de Janeiro: Fiocruz, 1999. 155 p.

BRÜMELIS, G.; BROWN, D.H.; NIKODEMUS, O.; TJARVE, D. The monitoring and risk assessment of Zn deposition around a metal smelter in Latvia. Environmental Monitoring and Assessment, v.58, p.201-212, 1999. Disponível em <http://www.periodicos.capes.gov.br>. Acesso em: 17 jan. 2004.

BULBOVAS, P. Efeitos da poluição atmosférica na Germinação e crescimento de plântulas de Euterpe edulis MART., na Região de Cubatão, SP. 2000. 115f. Dissertação (Mestrado) - Instituto de Biociências, Universidade de São Paulo, São Paulo, 2000.

BUSS, P. M. Promoção da saúde e qualidade de vida. Revista de Ciência e Saúde Coletiva. v.5, n.1, p.163-177, 2000.

CALASANS, C.F.; MALM. O. Elemental mercury contamination survey in a chlor-alkali plant by the use of transplanted Spanish moss, Tillandsia usneoides (L.). The Science of the Total Environment, v.208, p.165-177, 1997. Disponível em <http://www.sibi.usp.br/sibi/biblioteca/revista/selecao.php>. Acesso em: 17 jan. 2004. 
CALZADA, I.; MESANZA, J.; CASADO, H.; CASTILHO, F.J. Biochemical changes in needles of Pinus radiata Don trees in relationship to long-term ozone exposure indices. Environmental Pollution, v.114, p.325-335, 2001. Disponível em <http://www.sibi.usp.br/sibi/biblioteca/revista/selecao.php>. Acesso em: 17 jan. 2004.

CAMPOS, M. L. de A. Introdução à química de ambientes aquáticos e da atmosfera (apostila). Departamento de Química da Faculdade de Filosofia Ciências e Letras da Universidade de São Paulo. Ribeirão Preto, 2002.

CANADA. Health-risk perception Canada - a research report to Department of National Health and Welfare. Minister of Supply and Services. Canada, 1993.

CARIGNAN, J.; SIMONETTI, A.; GARIÉPY, C. Dispersal of atmospheric lead in northeastern North America as recorded by epiphytic lichens. Atmospheric Environmental, v.36, $\quad$ p.3759-3766, 2002. $\quad$ Disponível em <http://www.sibi.usp.br/sibi/biblioteca/revista/selecao.php>. Acesso em: 17 jan. 2004.

CARNEIRO, R.M.A.; TAKAYANGUI, A.M.M.; NERY, A.A.; BARBOSA, A.L.M. Experiência municipais sobre resíduos perigosos: avaliação, percepção e comunicação de riscos. In: I Fórum das Universidades Paulistas: ciência e tecnologia em resíduos. São Paulo: ICTR, 18 a 23 de maio, 2003, v.1, p.920-936 (CD-ROM).

CARRERAS, H. A.; PIGNATA, M. L. Comparison among air pollutants, meteorological conditions and some chemical parameters in the transplanted lichen Usnea amblyoclada. Environmental Pollution, v.111, p.45-52, 2001.

CEBURNIS, D.; STEINNES, E.; KVIETKUS. K. Estimation of metal uptake efficiencies precipitation in mosses in Lithuania. Chemosphere, v. 38, n. 2, p. 445-445, 1999. Disponível

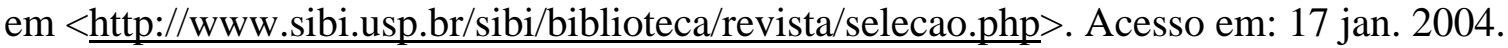

CEBURNIS, D.; STEINNES. E. Conifer needles as biomonitors of atmospheric heavy metal deposition: comparison with mosses and precipitation, role of the canopy. Atmospheric Environment, v.34, p.4265-4271, 2000.

CETESB. Relatório de qualidade do ar no estado de São Paulo, 1998. Secretaria de Meio Ambiente. São Paulo: CETESB, 1999.

CETESB. Relatório de qualidade do ar no Estado de São Paulo, 2001. Secretaria do Meio Ambiente. São Paulo: CETESB, 2002. Disponível em: <http:// www.cetesb.sp.gov.br> Acesso em: 03 mar. 2003. 
CHAPMAN, P. How toxic is toxic. Editorial. Marine Pollution Bulletin, v.42, n.11, p.12791280, 2001.

CHAPPELKA, A.; RENFRO, J.; SOMERS, G.; NASH, B. Evaluation of ozone injury on foliage of black cherry (Prunus serotina) and tall milkweed (Asclepias exaltata) in great smoky mountains national park. Environmental Pollution, v.95, n. 1, p.13-18, 1997. Disponível em <http://www.sibi.usp.br/sibi/biblioteca/revista/selecao.php>. Acesso em: 17 jan. 2004.

CHARURI, C. Como vai a sua mente? São Paulo: Associação Pró-Vida, 2003.

CHECKLIST OF LICHENS AND LICHENICOLOUS FUNGI. Disponível em $<$ http://www.biologie.uni-hamburg.de/checklist/world_l.htm.> Acesso em: 17 abr. 2004. (2004).

CLAIR, S. B. St. ; CLAIR, L.L. St.; MANGELSON, N.F.; WEBER, D.J. Influence of growth form on the accumularion of airborne copper by lichens. Atmospheric Environmental, v.36, p.5637-5644, $2002 . \quad$ Disponível em <http://www.sibi.usp.br/sibi/biblioteca/revista/selecao.php>. Acesso em: 17 jan. 2004.

CODERP. Conheça Ribeirão. Município de Ribeirão Preto: evolução da população.

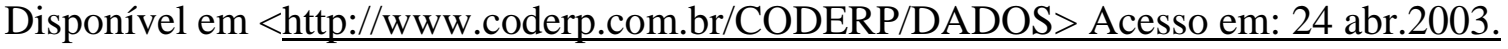

COLE, D. C.; PENGELLY, L.D.; EYLLES, J.; STIEB, D.M.; HUSTLER, R. Consulting the community for environmental health indicator development: the case of air quality. Health Promotion International, v.14, n.2,Great Britain, 1999.

CONFERÊNCIA NACIONAL DO MEIO AMBIENTE. Tese final. Brasília, 2003. Disponível em < http://www.mma.gov.br/conferencianacional > . Acesso em:03 mai. 2004.

CORRÊA, M.P. Dicionário das plantas úteis do Brasil. Rio de Janeiro: Imprensa Nacional, 1926-1978, v. I a III.

CORREAA, M.P. Dicionário das plantas úteis do Brasil. Rio de Janeiro: Instituto Brasileiro de Desenvolvimento Florestal, 1969-1978, v. IV a VI.

COUNSELL, C. Formulating questions and locating primary studies for inclusion in systematic reviews. Ann. Inter. Med. v.1, n.127, p.380-387, 1997. 
COVELLO, V. T. Risk communication and solid waste management: principles and guidelines for communication risk and uncertainty, 19-35 In HAIGHT, M. Municipal solid waste management - making decisions in the face of uncertainty. University of Waterloo, Press. Ontario, Canada, 1991.

CROSS, F. B. Facts and values in risk assessment. Reability Engineering and system safety, n.59, p.27-40, 1998.

DERISIO, J.C. Introdução ao controle de poluição ambiental. São Paulo: Signus Editora, $2^{\mathrm{a}}$ edição, 2000. 163 p.

DOBBEN van, H.F.; WOLTERBEEK ter, H.; WAMELINK, G.W.W.; BRAAK, C.J.F.T. Relationship between epiphytic lichens, trace elements and gaseous atmospheric pollutants. Environmental Pollution, v.112, p.163-169, 2001. Disponível em <http://www.sibi.usp.br/sibi/biblioteca/revista/selecao.php>. Acesso em: 17 jan. 2004.

DOBBEN van, H.F.; BRAAK ter, C.J.F. Ranking of Epiphytic lichen sensitivity to air pollution Using Survev Data: a comparison of indicator scales. Lichenologist, v.31, n1, p. 2739, 1999.

DOMINGOS, M.; KLUMPP, A.; KLUMPP, G. Air pollution impact on the Atlantic forest in the Cubatão region, SP, Brazil. Ciência e Cultura Journal of the Brazilian Association for the Advancement of Science, v. 50, n.4, p. 230-236, July/August 1998.

DONGARRÀ, G.; VARRICA. D. The presence of heavy metals in air particulate at Vulcano Island (Italy). The Science of the Total Environment, v.212, p.1-9, 1998. Disponível em <http://www.sibi.usp.br/sibi/biblioteca/revista/selecao.php>. Acesso em: 17 jan. 2004.

DUCHIADE, M. P. Poluição do ar e doenças respiratórias: uma revisão. Cadernos de Saúde Pública, v.8, n.3, p.302-310, jul./set., 1992.

EDULJEE, G. H. Trends in risk assessment and risk management. The science of the Total Environmental, 249, 13-23, 2000.

EL-HASAN, T.; AL-OMARI, H.; JIRIES, A.; AL-NASIR, F. Cypress tree (Cupressus sempervirens L.) bark as an indicator for heavy metal pollution in the atmosphere of Amman City, Jordan. Environmental International, v.28, p.513-519, 2002. Disponível em <http://www.periodicos.capes.gov.br>. Acesso em: 17 jan. 2004. 
ELLIOT, S. J.; COLE, D.C.; KRUEGER, P.; VOORBERG, N.; WAKEFIELD, S. The power of perception: health risk attributed to air pollution in a urban industrial neighborhood. Risk Anual, v.19, n.4, p.621-34, 1999.

ESTRADA, M. I. D. Meio Ambiente e complexos carboelétricos: o caso de Candiota. Revista Ciência Hoje, v.12, n.68, p.38-45, nov. 1990.

FAUS-KESSLER, T.; DIETL, C.; TRITSCHLER, J.; PEICHL, L. Correlation patterns of metals in the epiphytic moss Hypnum cupressiforme in Bavaria. Atmospheric Environment, v.32, n.2, $\quad$ p.427-439, $2000 . \quad$ Disponível <http://www.sibi.usp.br/sibi/biblioteca/revista/selecao.php>. Acesso em: 17 jan. 2004.

FELLENBERG, G. Introdução aos problemas de poluição. São Paulo: Ed. Univ. São Paulo, 1980. 169 p.

FERNÁNDEZ, J.A.; ABOAL, J.R.; CARBALLEIRA. A. Use of native and transplanted mosses as complementary techniques for biomonitoring mercury around an industrial facility. The Science of the Total Environment, v.256, p.151-161, 2000. Disponível em <http://www.sibi.usp.br/sibi/biblioteca/revista/selecao.php>. Acesso em: 17 jan. 2004.

FERNÁNDEZ, J.A.; CARBALLEIRA, A. Differences in the responses of native and transplanted mosses to atmospheric pollution: a possible role of selenium. Environmental Pollution, v.110, $\quad$ p. 73-78, 2000. $\quad$ Disponível em <http://www.sibi.usp.br/sibi/biblioteca/revista/selecao.php>. Acesso em: 17 jan. 2004.

FERREIRA, M.I.; PETRENKO, H.; LOBO, D.J.A.; RODRIGUES, G.S.; MOREIRA, A.; SALDIVA, P.H.N. In situ monitoring of the mutagenic effects of the gaseous emissions of a solid waste incinerator in metropolitan São Paulo, Brazil, using the Tradescantia stamen-hair assay. Journal of the Air \& Waste Management Association, v.50, p. 1852-1856, 2000.

FERREIRA, M.I.; RODRIGUES, G.S.; DOMINGOS, M.; SALDIVA, P.H.N. In sSitu monitoring of mutagenicity of air pollutants in São Paulo city using Tradescantia-SHM bioassay. Brazilian Archives of Biology and Technology, v.46, n.2, p. 253-258, 2003.

FIGUEIRA, R.; SÉRGIO, C.; SOUSA, A.J. Distribution of trace metals in moss biomonitors and assessment of contamination sources in Portugal. Environmental Pollution, v.118, p.153-163, 2002. Disponível em < http://www.sibi.usp.br/sibi/biblioteca/revista/selecao.php>. Acesso em: 17 jan. 2004.

FLORA MESOAMERICANA. Lista anotada. Disponível em <http://mobot.mobot.org/W3T/Search/meso.html>. Acesso em: 17 abr. 2004. 
FOLHA DE SÃO PAULO. Vazamento corta água de 8 cidades no RJ. São Paulo, p. C 4, 03 abr. 2003.

FORATINI, O. P. Ecologia, epidemiologia e sociedade. São Paulo: Artes Médicas. Editora da Universidade de São Paulo, 1992. 529p.

GARTY, J.; LEVIN, T.; COHEN, Y.; LEHR, H. Biomonitoring air pollution with the desert lichen Ramalina maciformis. Physiologia Plantarum. v.115, p.267, 2002. Disponível em <http://www.periodicos.capes.gov.br>. Acesso em: 17 jan. 2004.

GARTY, J.; TOMER, S.; LEVIN, T.; LEHR, H. Lichens as biomonitors around a coal-fired power station in Israel. Environmental Research, v.91, p.186-198, 2003. Disponível em <http://www.sibi.usp.br/sibi/biblioteca/revista/selecao.php>. Acesso em: 17 jan. 2004.

GARTY.J.; KLOOG.N.; COHEN. Y. Integrity of lichen cell membranes in relation to concentration of airborne elements. Arch. Environ. Contam. Toxicol. v. 34, p.136-144, 1998. Disponível em <http://www.sibi.usp.br/sibi/biblioteca/revista/selecao.php>. Acesso em: 17 jan. 2004.

GEEBELEN, W.; HOFFMANN, M. Evaluation of bio-indication methods using epiphytes by correlating with $\mathrm{SO}_{2}$ - pollution parameters. Lichenologist, v.33, n.3, p.249-260, 2001. Disponível em <http://www.sibi.usp.br/sibi/biblioteca/revista/selecao.php>. Acesso em: 17 jan. 2004.

GENONI, P.; PARCO, V.; SANTAGOSTINO, A. Metal biomonitoring with mosses in the surroundings of an oil-fired power plant in Italy. Chemosphere, v.41, p.729-733, 2000. Disponível em <http://www.sibi.usp.br/sibi/biblioteca/revista/selecao.php>. Acesso em: 17 jan. 2004.

GEOFF, N.; FRANCES, D. Environmental accumulation of airborne fluorides in Romania. Environmental Geochemistry and Health, v.23, p.43-51, 2001. Disponível em <http://www.sibi.usp.br/sibi/biblioteca/revista/selecao.php>. Acesso em: 17 jan. 2004.

GERDOL, R.; BRAGASSA, L.; MARCHESINI, R.; MEDICI, A.; PEDRINI, P.; BENENDETTI, S.; BOVOLENTA, A.; COPPI, S. Use of moss (Tortula muralis Hedw.) for monitoring organic and inorganic air pollution in urban and rural sites in Northern Italy. Atmospheric Environmental, v.36, p.4069-4075, 2002. Disponível em <http://www.sibi.usp.br/sibi/biblioteca/revista/selecao.php>. Acesso em: 17 jan. 2004. 
GIORDANI, P.; BRUNIALTI, G.; ALLETEO, D. Effects of atmospheric pollution on lichen biodiversity (LB) in a Mediterranean region (Liguria, Northwest Italy). Environmental

Pollution, $\quad$ v.118, $\quad$ p.53-64, 2002. $\quad$ Disponível $\quad$ em <http://www.sibi.usp.br/sibi/biblioteca/revista/selecao.php>. Acesso em: 17 jan. 2004.

GODOY, S.A.P.; PATRÍCIO, M.C. Sistemática das fanerógamas (apostila). Departamento de Biologia da Faculdade de Filosofia, Ciências e Letras de Ribeirão Preto da Universidade de São Paulo, Setor Botânica. Ribeirão Preto, 2001.

GODZIK, B. Ground level ozone concentrations in the Kraków region, Southern Poland. Environmental Pollution, v. 98, n. 3, p. 273 280, 1997. Disponível em <http://www.sibi.usp.br/sibi/biblioteca/revista/selecao.php> . Acesso em: 17 jan. 2004.

GOMBERT, S.; ASTA, J.; SEAWARD, M.R.D. Correlation between the nitrogen concentration of two epiphytic lichens and the traffic density in an urban area. Environmental Pollution, v.123, p.281-290, 2003. Disponível em

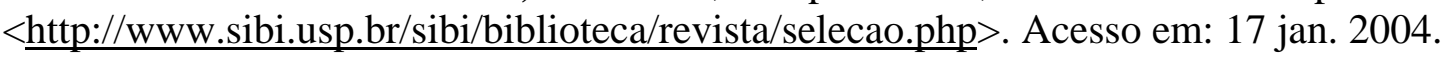

GONZÁLEZ, C.M.; PIGNATA, M.L. Chemical response of the lichen Punctelia subrudecta (NYL.) Krog transplanted close to a power station in an urban-industrial environment. Environmental Pollution, v. 97, n.3, p.195-203, 1997.

GONZÁLEZ, C.M.; PIGNATA, M.L. Chemical response of transplanted lichen Canomaculina pilosa to different emission sources of air pollutants. Environmental Pollution, v.110, p. 235-242, 2000. Disponível em <http://www.sibi.usp.br/sibi/biblioteca/revista/selecao.php>. Acesso em: 17 jan. 2004.

GOPALAN, H.N.B. Ecosystem health and human well being: the mission of the international programme on plant bioassays. Mutation Research, v. 426, p. 99-102, 1999.

GRAF, A.B. Tropica. $1^{\text {a }}$ edição. New Jersey: Rohers Company Publishers, 1978, 1120 p.

GRAF, A.B. Exotica Internacional. New Jersey: Rohers Company Publishers, 1985, série 4, v. 1,1280 p.

GRASSO, M.F.; CLOCCHIATTI, R.; CARROT, F.; DESCHAMPS, C.; VURRO, F. Lichens as bioindicators in volcanic areas: Mt. Etna and Vulcano Island (Italy). Environmental Geology, v.37, n. 3, p.207-216, 1999. Disponível em <http://www.sibi.usp.br/sibi/biblioteca/revista/selecao.php>. Acesso em: 17 jan. 2004. 
GRATANI, L.; CRESCENTE, M.F.; PETRUZZI, M. Relationship between leaf life-span and photosynthetic activity of Quercus ilex in polluted urban areas (Rome). Environmental Pollution, v.110, $\quad$ p.19-28, 2000. $\quad$ Disponível em <http://www.sibi.usp.br/sibi/biblioteca/revista/selecao.php>. Acesso em: 17 jan. 2004.

GREENHALGH, T. Papers that summarize other papers (systematic reviews and metaanalyses). BMJ, 315:672-3, 1997.

GRODZINSKA, K.; SZAREK-LUKASZEWSKA, G. Response of mosses to the heavy metal deposition in Poland - an overview. Environmental Pollution, v.114, p.443-451, 2001. Disponível em <http://www.sibi.usp.br/sibi/biblioteca/revista/selecao.php>. Acesso em: 17 jan. 2004.

GRODZINSKA-JURCZAK, M.; SZAREK-LUKASZEWSKA, G. Evolution of $\mathrm{SO}_{2}$ and $\mathrm{NO}_{2}$ related degradation of coniferous forest stands in Poland. The Science of the Total Environment, v.241, p.1-15, 1999.

GUIMARÃES, E.T.; DOMINGOS, M.; ALVES, E.S.; CALDINI JR, N.; LOBO, D.J.A.; LICHTENFELS, A.J.F.C.; SALDIVA. P.H.N. Detection of the genotoxicity of air pollutants in and around the city of São Paulo (Brazil) with the Tradescantia-micronucleus (Trad-MCN) assay. Environmental and Experimental Botany, v.44, n.1, p,1-8, 2000.

HALLERAKER, J.H.; REIMANN, C.; CARITAT, P.; FINNE, T.E.; KASHULINA, G.; NISKAAVAARA, H.; BOGATYREV, I. Reliability of moss (Hylocomium splendens and Pleurozium schreberi) as a bioindicator of atmospheric chemistry in the Barents region: interspecies and field duplicate variability. The Science of the Total Environment, v. 218, p.123-139, 1998. Disponível em <http://www.sibi.usp.br/sibi/biblioteca/revista/selecao.php> Acesso em: 17 jan. 2004.

HEAGLE, A.S.; STEFANSKI, L.A. Relationships between ambient ozone regimes and white clover forage production using different ozone exposure indexes. Atmospheric Environmet, v.34, $\quad$ p.735-744, 2000. $\quad$ Disponível em <http://www.sibi.usp.br/sibi/biblioteca/revista/selecao.php>. Acesso em: 17 jan. 2004.

HIATT, M.H. Leaves as an indicator exposure airborne volatile organic compounds. Environmental Science \& Technology, v.33, p.4126-4133, 1999. Disponível em <http://www.sibi.usp.br/sibi/biblioteca/revista/selecao.php>. Acesso em: 17 jan. 2004.

HIRANO, T.; MORIMOTO, K. Growth reduction of the Japanese black pine corresponding to an air pollution episode. Environmental Pollution, v.106, p.5-12, 1999. Disponível em <http://www.sibi.usp.br/sibi/biblioteca/revista/selecao.php>. Acesso em: 17 jan. 2004. 
HOLOUBEK, I.; KORÍNEK, P.; SEDA, Z.; SCHNEIDEROVÁ, E.; HOLOUBKOVÁ, I.; PACL, A.; TRÍSKA, J.; CUDLÍN, P.; CÁSLAVSKÝ. The use of mosses and pine needles to detect persistent organic pollutants at local and regional scales. Environmental Pollution, v.109, p.283-292, 2000.

JACOBI, P. Contaminação atmosférica: romper com a desinformação. Debatendo a poluição do ar. Coordenadoria de Educação Ambiental. Secretaria de Estado do Meio Ambiente, 2425. São Paulo, 1997.

JALKANEN, L.; MÄKINEN, A.; HÄSÄNEN, E.; JUHANOJA, J. The effect of large anthropogenic particulate emissions on atmospheric aerosols, deposition and bioindicators in the eastern Gulf of Finland region. The Science of the Total Environment, v.262, p.123136, 2000. Disponível em <http://www.sibi.usp.br/sibi/biblioteca/revista/selecao.php $>$. Acesso em: 17 jan. 2004.

JAMES, M.; CAMPBELL, M. Determining the human health risks of environmental chemicals. EPO, Toronto, 1991. In: Risk assessment workshop. Regional Municipality of Waterloo/ McMaster University. Environmental Program, nov.1994.

JEZIERSKI, A.; BYLINSKA, E.; SEAWARD, M.R.D. Electron paramagnetic resonance (EPR) investigations of lichens - 1: Effects of air pollution. Atmospheric Environmet, v.33, p. 4629-4635, 1999. 17 Disponível em <http://www.sibi.usp.br/sibi/biblioteca/revista/selecao.php>. Acesso em: 17 jan. 2004.

JOLY, A.B. Botânica: Introdução à taxonomia vegetal: 13 edição. São Paulo: Cia. Editora Nacional, 2002, 777p.

JUDD, W.S.; CAMPBELL, C.S.; KELLOG, E.A.; STEVENS, P.F. Plant systematic: a phylogenetic approch. Sunderland: Sinauer Associate, Inc., 1999, 464p.

KAMMERBAUER, J.; DICK, T. Monitoring of urban traffic using some physiological indicators in Riccinus communis L. plants. Arch. Environ. Contam. Toxicol., 39(2): 161166, 2000.

KANOUN, M.; GOULAS, M.J.P.; BIOLLEY, J.P. Effect of a chronic and moderate ozone pollution on the phenolic pattern of bean leaves (Phaseolus vulgaris L. cv. Nerina): relations with visible injury and biomass production. Biochemical Systematics and Ecology, v.29, p.443-457, 2001. Disponível em <http://www.sibi.usp.br/sibi/biblioteca/revista/selecao.php>. Acesso em: 17 jan. 2004.

KAUFMAN, W. Air pollution and forest: an update. American Forest, v.95, n.5/6, p.36-44, 1989. 
KEANE, B.; COLLIER, M.H.; SHANN, J.R.; ROGSTAD, S.H. Metal content of dandelion (Taraxacum offcinale) leaves in relation to soil contamination and airborne particulate matter. The Science of the Total Environment , v. 281, p. 63-78, 2001. Disponível em <http://www.sibi.usp.br/sibi/biblioteca/revista/selecao.php>. Acesso em: 17 jan. 2004.

KEYMEULEN, R.; GÖRGÉNYI, M.; HÉBERGER, K.; PRIKSANE, A.; LANGENHOVE, H.V. Benzene, toluene, ethyl benzene and xylenes in ambient air and Pinus sylvestris L. needles: a comparative study between Beligium, Hungary ant Latvia. Atmospheric Environmental, v.35, p.6327-6335, 2001. Disponível em <http://www.sibi.usp.br/sibi/biblioteca/revista/selecao.php>. Acesso em: 17 jan. 2004.

KLEIER, C.; FARNSWORTH, B.; WINNER, W. Photosynthesis and biomass allocation of radish cv. "Chery Belle" in response to root temperature and ozone. Environmental Pollution, v.111, p.127-133, 2001. 2 Disponível em <http://www.sibi.usp.br/sibi/biblioteca/revista/selecao.php>. Acesso em: 17 jan. 2004.

KLUMPP, A.; ANSEL, W.; KLUMPP, G.; FOMIN, A. Um novo conceito de monitoramento e comunicação ambiental: a rede européia para a avaliação da qualidade do ar usando plantas bioindicadoras (EuroBionet). Rev. Bras. Bot., n. 4. supl., 511-518, dez. 2001.

KLUMPP, A.; DOMINGOS, G.; KLUMPP, G. Assessment of the vegetation risk by fluoride emissions from fertilizer industries at Cubatão, Brazil. The Science of the Total Environment, v.192, p.219-228, 1996.

KLUMPP, A.; DOMINGOS, M.; MORAES, R.M.; KLUMPP, G. Effects of complex air pollution on tree species of the Atlantic Rain Forest near Cubatão, Brazil. Chemosphere, v.36, n. 4-5, p. 989-994, 1998.

KLUMPP, A.; KLUMPP, G.; DOMINGOS, M. Plants as bioindicators of air pollution at Serra do Mar near the industrial complex of Cubatão, Brazil. Environmental Pollution, v.85, n.1, p.109-116, 1994.

KLUMPP, G.; FURLAN, C;M.; DOMINGOS, M.; KLUMPP. A. Response of stress indicators and growth parameters of Tibouchina pulchra Cogn. exposed to air and soil pollution near the industrial complex of Cubatão, Brazil. The Science of Total Environment, v.246, p.79-91, 2000.

KOPPER, B.J.; LINDROTH, R.L.; NORDHEEIM, E.V. $\mathrm{CO}_{2}$ an $\mathrm{O}_{3}$ effects on paper birch (Betulaceae: Betula papyrifera) phytochemistry and whitemarked tussock moth (Lymantriidae: Orgyia leucostigma) performance. Entomological society of America, v30, n.6, p.1119-1126, 2001. Disponível em <http://www.periodicos.cpes.gov.br $>$. Acesso em: 17 jan. 2004. 
KRUPA, S.V.; LEGGE, A.H. Foliar injury symptoms of Saskatoon serviceberry (Amelanchier alnifolia Nutt.) as a biological indicador of ambient sulfur dioxide exposures. Environmental Pollution, v.106, p.449-454, 1999. Disponível em <http://www.sibi.usp.br/sibi/biblioteca/revista/selecao.php>. Acesso em: 17 jan. 2004.

KUBIZÑÁKOVÁ, J. Atmospheric pollution as a stressor in disturbed spruce stands. Ekológica (Bratislava), v. 20, n. 1, p.80-94, 2001.

KUEHLER, E.A.; FLAGLER, R.B. The effects of sodium erythorbate and ethylenediurea on photosynthetic function of ozone-exposed loblolly pine seedlings. Environmental Pollution, v. 105, p. $1999.35, \quad$ Disponível <http://www.sibi.usp.br/sibi/biblioteca/revista/selecao.php>. Acesso em: 17 jan. 2004.

KURCZYNSKA, E.U.; DMUCHIWSKI, W.; WLOCH, W.; BYTNEROWICZ, A. The influence of air pollutants on needles and stems of Scots pine (Pinus sylvestrys L.) trees. Environmental Pollution, v. 98, n.3, p. 325 334, 1997. Disponível em <http://www.sibi.usp.br/sibi/biblioteca/revista/selecao.php>. Acesso em: 17 jan. 2004.

LEISS, W. Three phases in the evaluation of risk communication practice. Environmental Policy Unit. Queen’s University. Working paper, series 95-2. Ontario, Sept. 1995.

LIMA, J.S.; FERNANDES, E. B.; FAWCETT, W. N. Mangifera indica and Phaseolus vulgaris in the bioindication of air pollution in Bahia, Brazil. Ecotoxicology and Environmental Safety, v.46, p.275-278, 2000. Disponível em <http://www.sibi.usp.br/sibi/biblioteca/revista/selecao.php>. Acesso em: 17 jan. 2004.

LODOVICI, M.; AKPAN, V.; CASALINI, C.; ZAPPA, C.; DOLARA, P. Polycyclic Aromatic Hydrocarbons in Laurus nobilis as a measure of air pollution in urban and rural sites of Tuscany. Chemosphere, v.36, n.8 p. 703-1712, 1998. Disponível em <http://www.sibi.usp.br/sibi/biblioteca/revista/selecao.php>. Acesso em: 17 jan. 2004.

LOPPI, S. Environmental distribution of mercury and other trace elements in the geothermal area of Bagnore (Mt. Amiata, Italy). Chemosphere, v.45, p.991-995, 2001. Disponível em <http://www.sibi.usp.br/sibi/biblioteca/revista/selecao.php>. Acesso em: 17 jan. 2004.

LOPPI, S.; BONINI, I. Lichens and mosses biomonitors of trace elements in areas with springs and fumarole activity (Mt. Amiata, central Itally). Chemosphere, v.41, p.1333-1336,

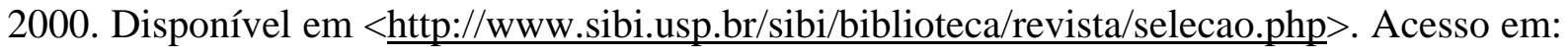
17 jan. 2004. 
LOPPI, S.; CENNI, E.; BUSSOTI, F.; FERRETTI, M. Biomonitoring of Geothermal air pollution by lichens and forest trees. Chemosphere, v.36, n.4-5, p.1079-1082, 1998. Disponível em <http://www.sibi.usp.br/sibi/biblioteca/revista/selecao.php>. Acesso em: 17 jan. 2004.

LOPPI, S.; PUTORTI, E.; PIRINTSOS, S.A.; DOMINICIS, V. Accumulation of heavy metals in epiphytic lichens near a municipal Solid Waste Incinerator (Central Italy). Environmental Monitoring and Assessment, v.61, p.361-371, 2000. Disponível em <http://www.periodicos.capes.gov.br>. Acesso em: 17 jan. 2004.

LORENZI, H. Árvores brasileiras: manual de identificação e cultivo de plantas arbóreas nativas do Brasil. Nova Odessa: Editora Plantarum, 1992, 352 p., vol. 1.

LORENZI, H. Árvores brasileiras: manual de identificação e cultivo de plantas arbóreas do Brasil. 2a edição. Nova Odessa: Editora Plantarum, 1998, 352 p., vol. 2.

LORENZI, H.; SOUZA, H. M. Plantas ornamentais no Brasil: arbustivas, herbáceas e trepadeiras. Nova Odessa: Editora Plantarum, 1995, 720 p.

LORENZI, H.; SOUZA, H. M.; TORRES, M.A.V.; BACHER, L.B. Árvores exóticas no Brasil: madeireiras, ornamentais e aromáticas. Nova Odessa: Instituto Plantarum, 2003, 368 p.

MA, T. H. Application of quick and simple plant bioassays to assess the genotoxicity of environmental Pollutants: detection of potential health hazards of air, water and soil contaminants. In: Eurotox Congress. Basel, Switzerland, p. 420-433, 1993.

MA, T. H. The international program on plant bioassay and the report of the follow-up study after the hands-on workshop in China. Mutation Reserch, n.426, p.103-106, 1999.

MADKOUR, S.A.; LAURENCE, J.A. Egyptian plant species as new ozone indicators. Environmental Pollution, v.120, p.339-353, 2002. Disponível em <http://www.sibi.usp.br/sibi/biblioteca/revista/selecao.php>. Acesso em: 17 jan. 2004.

MALAVOLTA, E. Absorção e transporte de íons e nutrição mineral. In: FERRI, M.G. (Org.). Fisiologia vegetal I, $2^{a}$ edição. São Paulo: Editora Pedagógica e Universitária Ltda., 1985, v. 1, Cap. 2, 77-96. 
MALM, O.; FONSECA, M.F.; MIGUEL, P. H.; BASTOS, W. R.; PINTO, F. N. Use of epiphyte plants as biomonitors to map atmospheric mercury in a gold trade center city, Amazon, Brazil. The Science of the Total Environment, v. 213, p. 57-64, 1998.

MANKOVSKÁ , B. Deposition of heavy metals in Slovakia - Assessment on the basis of moss and analyses. Ekológica (Bratislava), v.16, n.4, p. 433-422, 1997.

MANNING, W.J.; GODZIK, B.; MUSSELMAN, R. Potential bioindicator plant species for ambient ozone in forested mountain areas of central Europe. Environmental Pollution, v.119, p.283-290, 2002. $\quad$ Disponível em <http://www.sibi.usp.br/sibi/biblioteca/revista/selecao.php>. Acesso em: 17 jan. 2004.

MARTINE, G. População, meio ambiente e desenvolvimento: o cenário global e nacional. In: MARTINE, G. População, Meio Ambiente e Desenvolvimento: verdades e contradições.

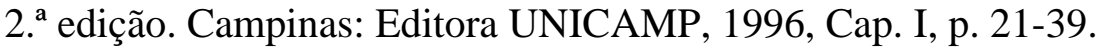

MENDONÇA, B. R., SILVA, E. A. M. Efeito da poluição sobre bioindicadores vegetais. AMBIENTE, v.5, n.1, 37-40, 1991.

MILLAR, J. D. Quantitative risk assessment: a tool to be used responsibly. Journal of public health policy, vol. 13, n. 1, 1992.

MINAYO, M.C. de S. Ciência, técnica e arte: o desafio da pesquisa social. In: DESLANDES, S. F. (org.) Pesquisa social: teoria, método e criatividade. Petrópolis: Vozes, 1994, Cap.1, 9-29.

MISSOURI BOTANICAL GARDEN - W3MOST. Index of mosses database. Disponível em: <http://mobot.org/MOBOT/tropicos/most/bryolist.html>. Acesso em: 17 abr. 2004.

MISSOURI BOTANICAL GARDEN - W3T. Vascular tropicos nomenclatural database. Disponível em <http://mobot.mobot.org/W3T/Search/vast.html > . Acesso em: 07 abr. 2004.

MONARCA, S.; FERETTI, D.; ZANARDINI, A.; FALISTOCCO, E.; NARDI, G. Monitoring of mutagens in urban air samples. Mutation Research, v.426, p.189-192, 1999. Disponível em <http://www.sibi.usp.br/sibi/biblioteca/revista/selecao.php>. Acesso em: 17 jan. 2004.

MORAES, R.M.; DELITTI, W.B.C.; MORAES, J.A.P.V. Respostas de indivíduos jovens de Tibouchina pulchra Cogn, à poluição aérea de Cubatão, SP: fotossíntese líquida, crescimento e química foliar. Rev. Brasil. Bot., São Paulo, v.23, n.4, p. 441-447, 2000. 
MORAES, R.M.; KLUMPP, A.; FURLAN, C.M.; KLUMPP, G.; DOMINGOS, M.; RINALDI, M.C.S.; MODESTO, I.F. Tropical fruit trees as bioindicators of industrial air pollution in southeast Brazil. Environmental International, v.28, p.367-374, 2002. Disponível em <http://www.sibi.usp.br/sibi/biblioteca/revista/selecao.php>. Acesso em: 17 jan. 2004.

MUÑOZ, S. I. S.; TAKAYANAGUI, A.M.M.; SANTOS, C.B.; SANCHEZ_SWEATMAN, O. Revisão Sistemática de literatura e metanálise: desenho, interpretação e aplicação na área da saúde. Anais do 8. ${ }^{\circ}$ Simpósio de Comunicação em Enfermagem. SIBRACEN. May. 2002. Disponível em: http://www.proceedings.scielo.br/ - Eventos.

NATIONAL STANDART OF CANADA (NSC). Risk analysis requirements and guidelines. Canadian Standads Association. Ontario, 1991.

NIEMI, R.; MARTIKAINEN, P.J.; SILVOLA, J.; HOLOPAINEN, T. Ozone effects on Sphagnum mosses, carbon dioxide exchange and methane emission in boreal peatland microcosms. The Science of the Total Environment , v. 289, p. 1-12, 2002. Disponível em <http://www.sibi.usp.br/sibi/biblioteca/revista/selecao.php>. Acesso em: 17 jan. 2004.

NIMIS, P.L.; ANDREUSSI, S.; PITTAO, E. The performance of two lichen species as bioaccumulators of trace metals. The Science of the Total Environment, v.275, p.43-51, 2001. Disponível em < http://www.sibi.usp.br/sibi/biblioteca/revista/selecao.php $>$. Acesso em: 17 jan. 2004.

NIMIS, P.L.; LAZZARIN, G.; LAZZARIN, N.; SKERT, N. Biomonitoring of trace elements with lichens in Veneto (NE Italy). The Science of the Total Environment, v.255, p.97-111, 2000. Disponível em < $<$ http://www.sibi.usp.br/sibi/biblioteca/revista/selecao.php $>$. Acesso em: 17 jan. 2004.

NORMANDIN, L.; KENNEDY, G.; ZAYED, J. Potential of dandelion (Taraxacum officinale) as a bioindicador of manganese arising from the use of methylcyclopentadienyl manganese tricarbonyl in unleaded. The Science of the Total Environment, v.239, p.165171, 1999. Disponível em <http://www.sibi.usp.br/sibi/biblioteca/revista/selecao.php $>$. Acesso em: 17 jan. 2004.

ODUKOYA, O.O.; AROWOLO,T.A.; BAMGBOSE, O. Ph, Zn, and Cu levels in tree barks as indicator of atmospheric pollution. Environmental International, v.26, p.11-16, 2000. Disponível em <http://www.sibi.usp.br/sibi/biblioteca/revista/selecao.php>. Acesso em: 17 jan. 2004. 
OMASA, K.; TOBE, K.; HOSOMI, M; KOBAYASHI, M. Absorption ozone and seven organic pollutants by Populus nigra and Camelia sasanqua. Environmental Science \& Technology, v.34, p.2498-2500, 2000. $\quad$ Disponível em <http://www.sibi.usp.br/sibi/biblioteca/revista/selecao.php>. Acesso em: 17 jan. 2004.

OLCESE, L. E.; TOSELLI, B. M. Some aspects of air pollution in Córdoba, Argentina. Atmospheric environment, 36, 299-306, 2002.

ORGANIZAÇÃO DAS NAÇÕES UNIDAS (ONU). Conferência das Nações Unidas sobre o Meio Ambiente e Desenvolvimento: Declaração do Rio sobre meio ambiente e desenvolvimento. Rio de Janeiro, jun. 1992. In: Dias, G. F. Educação Ambiental: princípios

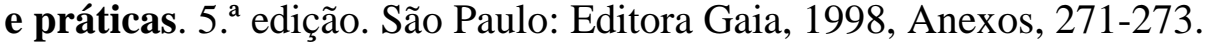

ORLANDI, M.; PELFINI, M.; PAVAN, M.; SANTILLI, M.; COLOMBINI, M.P. heavy metals variations in some conifers in Valle d'Aosta (Western Italian Alps) form 1930 to 2000. Microchemical Journal, v.73, p.237-244, 2002. Disponível em <http://www.sibi.usp.br/sibi/biblioteca/revista/selecao.php>. Acesso em: 17 jan. 2004.

PASQUALINI, V.; ROBLES, C.; GARZINO, S.; GREFF, S.; BOUSQUET-MELOU, A.; BONIN, G. Phenolic compounds content in Pinus halepensis Mill. needles: a bioindicator of air pollution. Chemosphere, v.52, p.239-248, 2003. Disponível em <http://www.sibi.usp.br/sibi/biblioteca/revista/selecao.php>. Acesso em: 17 jan. 2004.

PEÑUELAS, J.; RIBAS, A.; GIMENO, B.S.; FILELLA, I. Dependence of ozone biomonitoring on meteorological conditions of diferent sites in Catalonia (N.E.Spain). Environmental Monitoring and Assessment, v.56, p.221-224, 1999. Disponível em <http://www.periodico.capes.gov.br>. Acesso em: 17 jan. 2004.

PEITER, P.; TOBAR, C. Poluição do ar e condições de vida: uma análise geográfica de riscos à saúde em Volta Redonda, Rio de Janeiro, Brasil. Cadernos de Saúde Pública, 14(3), 473485, jul-set, 1998.

PENGELLY, L. D. F. Health effects of air pollution assessed using Ontario health survey data. Final report for project. Institute of Environmental and Health, McMaster University and University of Toronto, Dec. 1992.

PIGNATA, M.L.; GUDIÑO, G.L.; CAÑAS, M.S.; ORELLANA, L. Relationship between foliar chemical parameters measured in Melia azedarach L. and environmental conditions in urban areas. The Science of the Total Environment , v. 243/244, p. 85-96, 1999. Disponível

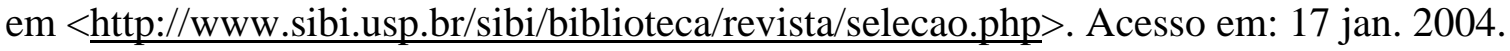


PIGNATA, M.L.; GUDIÑO, G.L.; WANNAZ, E.D.; PLÁ, R.R.; GONZÁLEZ，C.M.; CARRERAS, H.A.; ORELLANA, L. Atmospheric quality and distribution of heavy metals in Argentina employing Tillandsia capillaris as a biomonitor. Environmental Pollution, v.120, p.59-68, 2002. Disponível em <http://www.sibi.usp.br/sibi/biblioteca/revista/selecao.php>. Acesso em: 17 jan. 2004.

POIKOLAINEN, J.; KUUSINEN, M.; MIKKOLA, K.; LINDGREN. M. Mapping of the epiphytic lichens on conifers in Finland in the years 1985-86 and 1995. Chemosphere, v.36, n.4-5, p.1073-1078, $1998 . \quad$ Disponível em <http://www.sibi.usp.br/sibi/biblioteca/revista/selecao.php>. Acesso em: 17 jan. 2004.

POMPÉIA, S.L. Sucessão secundária da Mata Atlântica em Áreas Afetadas pela poluição atmosférica Cubatão, SP. 1997. 193f. Tese (Doutorado) - Instituto de Biociências, Universidade de São Paulo, São Paulo, 1997.

RAUTIO, P.; HUTTUNEM, S. Total vs. internal element concentrations in Scots pine needles along a sulfur and metal pollution gradient. Environmental Pollution, v.122, p.273-289,

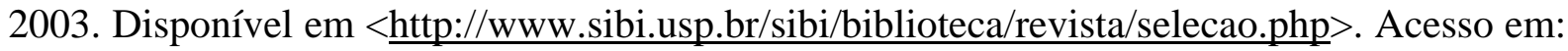
17 jan. 2004.

RIBAS, A.; PEÑUELAS, J. Biomonitoring of tropospheric ozone phytotoxicity in rural Catalonia. Atmospheric Environmental, v.37, p.63-71, 2003. Disponível em

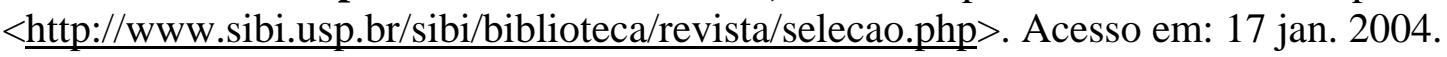

RIGA-KARANDINOS, A. N.; KARANDINOS, M. G. Assessment of air pollution from a lignite power plant in the plain of Megalopolis (Greece) using as biomonitors three species of lichens: impacts on some biochemical parameters of lichens. The Science of the Total Environment, v. 215, p.167-183, 1998. Disponível em <http://www.sibi.usp.br/sibi/biblioteca/revista/selecao.php>. Acesso em: 17 jan. 2004.

RIGET, F.; ASMUND, G.; AASTRUP, P. The use of lichen (Cetraria nivalis) and moss (Rhacomitriun lanuginosum) as monitors for atmospheric deposition in Greenland. The Science of the Total Environment , v. 245, p. 137-148, 2000. Disponível em <http://www.sibi.usp.br/sibi/biblioteca/revista/selecao.php>. Acesso em: 17 jan. 2004.

RIBEIRÃO PRETO. Lei n. ${ }^{\circ} 8681$ de 20/01/2000. Dispõe sobre a ocupação industrial e de prestação de serviços no Município de Ribeirão Preto e dá outras providências. Diário Oficial do Município de 15 de fev. 2000. Disponível em:<http://www.ribeiraopreto.sp.gov.br>. Acesso em 12 abr. 04.

RINNE, R. J. K.; MAKIENEN, A. I. Regional and species variations in metal contents of two woodland mosses Pleurozium schreberi and Hylocomin splendensin Finland and Northern Norway. SILVA FENNICA, v.22, n.1, 89-97, 1988. 
RODRIGUES, G.S.; MA, T. H.; PIMENTEL, D. WEINSTEIN, L.H. Tradescantia Bioassays as Monitoring Systems for Environmental Mutagenesis: a review. Critical Reviews in Plant Sciences, v.16, n. 4, p.325-359, 1997.

ROSMAN, K.J.R.; LY, C.; STEINNES, E. Spatial and Temporal Variation in Isotopic Composition of Atmospheric Lead in Norwegian Moss. Environmental Science \& Technology, v.32, n.17, p.2542-2546, 1998. Disponível em

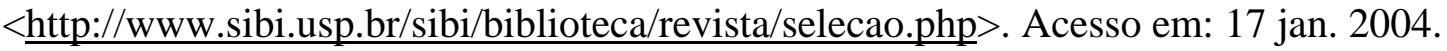

ROSSBACH, M.; JAYASEKERA, R.; KNIEWALD, G.; THANG, N.H. Large scale air monitoring: lichen vs. air particulate matter analysis. The Science of the Total Environment, v.232, p.59-66, $1999 . \quad$ Disponível em <http://www.sibi.usp.br/sibi/biblioteca/revista/selecao.php>. Acesso em: 17 jan. 2004.

SÃO PAULO (ESTADO). Lei n. ${ }^{o} 977$ de 31/05/1976. Dispõe sobre o controle da poluição do meio ambiente. 1976 a. Disponível em: <http://www.imprensaoficial.com.br/cgi/on> Acesso em: 24 set. 2002.

SÃO PAULO (ESTADO). Decreto n. ${ }^{\circ} 8.468$ de 08/09/1976. Aprova o regulamento da Lei n. ${ }^{\circ}$ 997/76, que dispõe sobre o controle de poluição do meio ambiente. 1976 b. Disponível em: <http://www.imprensaoficial.com.br/cgi/on> Acesso em: 24 set. 2002.

SAITANIS, C.J.; KARANDINOS, M.G. Instrumental recording and biomonitoring of ambient ozone un the Greek countryside. Chemosphere, v.44, p. 813-821, 2001. Disponível em < http://www.sibi.usp.br/sibi/biblioteca/revista/selecao.php>. Acesso em: 17 jan. 2004.

SAITANIS, C.J.; KARANDINOS, M.G. Effects of ozone on Tobacco (Nicotiana tabacum L.) Varieties. J. Agronomy \& Crop Science. v. 188, p. 51-58, 2002. Disponível em <http://www.sibi.usp.br/sibi/biblioteca/revista/selecao.php>. Acesso em: 17 jan. 2004.

SAITANIS, C.J.; RIGA-KARANDINOS, A.N.; KARANDINOS, M.G. Effects of ozone on chlorophyll and quantum yield of tobacco (Nicotiana tabacum L.) varieties. Chemosphere, v.42, p.945-953, 2001. $\quad$ Disponível em <http://www.sibi.usp.br/sibi/biblioteca/revista/selecao.php>. Acesso em: 17 jan. 2004.

SALDIVA, P. H. N.; LICHTENFELS, A.J.; PAIVA, P.S.; BARONE, I.A.; MARTINS, M.A.; MASSAD, E.; PEREIRA, J.C.; XAVIER, V. P.; SINGER, J.M.; BOHM, G.M. Association between air pollution and mortality due to respiratory diseases in children in São Paulo, Brazil: a preliminary report. Environmental research, 65, 218-225, 1994. 
SALDIVA, P. H. N. Efeitos da poluição atmosférica na saúde. Debatendo a poluição do ar. Coordenadoria de Educação Ambiental. Secretaria de Estado do Meio Ambiente, p. 24. São Paulo, 1997.

SAMECKA-CYMERMAN, A.; KEMPERS, A. J. Bioindication of heavy metals in the town Wroclaw (Poland) with evergreen plants. Atmospheric Environment, v.33, p. 419-430,

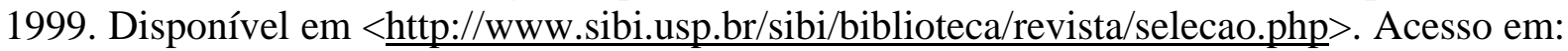
17 jan. 2004.

SCERBO, R.; POSSENTI, L.; LAMPUGNANI, L.; RISTORI, T.; BARALE, R. Lichen (Xanthoria parietina) biomonitoring of trace element contamination and air quality assessment in Livorno Province (Tuscany, Italy). The Science of the Total Environment, v.241, p.91-106, 1999. 1 Disponível em

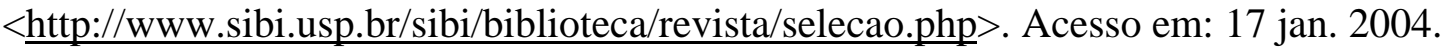

SCHRAUDNER, M.; MOEDER, W.; WIESE, C.; CAMP, W.V.; INZÉ, D.; LANGEBARTELS, C.; SANDERMANN JR., H. Ozone-induced oxidative burst in the ozone biomonitor plant, tobaco Bel W3. The Plant Journal, v.16, n.2, p.235, 1998. Disponível em <http://www.sibi.usp.br/sibi/biblioteca/revista/selecao.php>. Acesso em: 17 jan. 2004.

SHEN, X.; YAN, C.H.; WU, S.M.; LI, R.Q.; HUANG, H.; AO, L.M.; ZHOU, J.D.; HONG, Z.Y.; XU, J.D.; JIN, X.M.; TANG, J.M. Low-level prenatal lead exposure and neurobehavioral development of children in the first year of life: a prospective study in Shangai. Environmental research, section A, 79, 1-8, 1998.

SILVA, L.C. da; AZEVEDO, A.A.; SILVA, E.A.M.; OLIVA, M.A. Flúor em chuva simulada: sintomatologia e efeitos sobre a estrutura foliar e o crescimento de plantas arbóreas. Rev. Brasil. Bot., São Paulo, v.23, n.4, p. 383-391, 2000.

SLOVIC, P. Perception of risk. In: Elliot, S., Eyles, J., Scott, F. Diploma program in environmental health: term II, module VIII - Risk communication. McMaster University, Sept. 2000.

SMITH, G.M. Botânica Criptogâmica: algas e fungos. Tradução de Carlos das Neves Tavares. 2. ${ }^{a}$ edição. Lisboa: Fundação Calouste Gulbenkian, 1969, 527 p.

SMITH, G.M. Botânica Criptogâmica: briófitos e pteridófitos. Tradução de Carlos das Neves Tavares. 2. ${ }^{\mathrm{a}}$ edição. Lisboa: Fundação Calouste Gulbenkian, 1970, 386 p.

SOUTH RIVERDALE COMMUNITY HEALTH CENTRE. Why barns are red: the health risks from lead and their prevention. Metropolitan Toronto teaching health units. Toronto, 1995. 
SUMITA, N.M.; MENDES, M.E.; MACCHIONE, M.; GUIMARÃES, E.T.; LICHTENFELS, A.J.F.C.; LOBO, D.J.A.; SALDIVA, P.H.N. Tradescantia pallida cv. purpurea Boom in the characterization of air pollution by accumulation of tTrace elements. Journal of the Air \& Waste Management Association, v.53, p. 574-579, 2003.

SUYAMA, F.; GUIMARÃES, E.T.; LOBO, D.J.A.; RODRIGUES, G.S.; DOMINGOS, M.; ALVES, E.S.; CARVALHO, H.A.; SALDIVA, P.H.N. Pollen mother cells of Tradescantia clone 4430 and Tradescantia pallida var. purpurea are equally sensitive to the clastogenic effects of X-rays. Brazilian Journal of Medical and Biological Research, v.35, p. 127-129, 2002.

SZAREK-LUKASZEWSKA, G.; GRODZINSKA, K; BRANIEWSKI, S. Heavy metal concentration in the moss Pleurozium schreberi in the Niepolomice Forest, Poland: chances during 20 years. Environmental Monitoring and Assessment, v.79, p.231-237, 2002. Disponível em <http://www.periodicos.capes.gov.br>. Acesso em: 17 jan. 2004.

TONCELLI, M.L.; LORENZINI, G. Comparative evaluation of biomonitoring Techniques of tropospheric ozone. Environmental Monitoring and Assessment, v.55, p.445-458, 1999. Disponível em <http://www.periodicos.capes.gov.br>. Acesso em: 17 jan. 2004.

TONNEIJCK, A.E.G.; BERGE, W.F.; JANSEN, B.P. Monitoring the effects of atmospheric ethylene near polyethylene manufacturing plants with two sensitive plant species. Environmental Pollution, v.123, p.275-279, 2003.

TORRES, H. da G. Indústrias sujas e intensivas em recursos naturais: importância crescente no cenário industrial brasileiro. In: MARTINE, G. População, Meio Ambiente e Desenvolvimento: verdades e contradições. 2." edição. Campinas: Editora UNICAMP, 1996. Cap. II, 43-67.

TRIMBACHER, C.; WEIS, P. Needle surface characteristics and element contents of Norway spruce in relation to the distance of emission sources. Environmental Pollution, v.105, p. 11119, 1999.

UHLIG, C.; JUNTTILA, O. Airborne heavy metal pollution and its effects on foliar elemental composition of Empetrum hermaphroditum and Vaccinium myrtillus in Sor-Varanger, northern Norway. Environmental Pollution, v.114, p. 461-469, 2001. Disponível em <http://www.sibi.usp.br/sibi/biblioteca/revista/selecao.php>. Acesso em: 17 jan. 2004.

UNITED STATES ENVIRONMENTAL PROTECTION AGENCY (USEPA). EPA response to September 11. Volatile organic compounds in air. Disponível em $<$ http://epa.gov/wtc/voc/>. Acesso em 01 mai. 2004a. 
UNITED STATES ENVIRONMENTAL PROTECTION AGENCY (USEPA). Mobile sources emissions: past, present and future. Hydrocarbons. Disponível em $<$ http://epa.gov/otaq/invntor/overview/pollutants/hydrocarbons.html>. Acesso em 03 mai. 2004b.

VASCONCELOS, M.T.S.D.; TAVATES, H.M.F. Atmospheric metal pollution (Cr, $\mathrm{Cu}, \mathrm{Fe}$, $\mathrm{Mn}, \mathrm{Ni}, \mathrm{Pb}$, and $\mathrm{Zn}$ ) in Oporto city derived from results for low-volume aerosol samplers and for the moss Sphagnum auriculatum bioindicador. The Science of the Total Environment, v.212, $\quad$ p.11-20, $1998 . \quad$ Disponível em

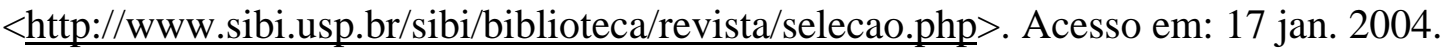

VEGARA, A. Territórios inteligentes: novos horizontes no urbanismo. Desenvolvimento Urbano e Meio Ambiente, n. 48, ano 11, Curitiba, 2002.

VERGÉ, X.; CHAPUIS, A.; DELPOUX, M. Bioindicator reliability: the example of Bel W3 tobacco (Nicotiana tabacum L.). Environmental Pollution, v.118, p.337-349, 2002. Disponível em <http://www.sibi.usp.br/sibi/biblioteca/revista/selecao.php>. Acesso em: 17 jan. 2004.

VILELA, E. M.; MENDES, I. J. M. Entre Newton e Eisnten: desmedicalizando o conceito de saúde. Ribeirão Preto: Holos Editora, 2000, 83p.

WADLEIGH, M.A.; BLAKE, D.M. Tracing sources of atmospheric using epiphytic lichens. Environmental Pollution, v.106, p.265-271, $1999 . \quad$ Disponível em <http://www.sibi.usp.br/sibi/biblioteca/revista/selecao.php>. Acesso em: 17 jan. 2004.

WAPPELHORST O.; KÜHN I.; OEHLMANN J.; MARKERT B. Deposition and disease: a moss monitoring project as an approach to ascertaining potential connections. The Science of the Total Environment, v. 249, p. 243-256, 2000. Disponível em <http://www.sibi.usp.br/sibi/biblioteca/revista/selecao.php>. Acesso em: 17 jan. 2004.

WEISS, D.; SHOTYK, W.; KRAMERS, J.D.; GLOOR, M.. Sphagnum mosses as archives of recent and past atmospheric lead deposition in Switzerland. Atmospheric Environment, v.33, p.3751-3763, $1999 . \quad$ Disponível em <http://www.sibi.usp.br/sibi/biblioteca/revista/selecao.php>. Acesso em: 17 jan. 2004.

WESTPHAL, M. F. Municípios Saudáveis: aspectos conceituais. In: Faculdade de Saúde Pública e Associação Paulista de Saúde Pública. Saúde e Sociedade. São Paulo: FSPUSP/APSP, 1997, v. 6, n. 2, p. 9-18.

WORLD HEALTH ORGANIZATION (WHO). Ottawa charter for health promotion. In: International Conference on Health Promotion. Ottawa, WHO, 1986. 
WORLD HEALTH ORGANIZATION (WHO). World day: How mark world health day. Geneva, WHO, 1990.

XIAO, Z.; SOMMAR, J.; LINDQVIST, O.; GIOULEKA, E. Atmospheric mercury deposition to grass in southern Sweden. The Science of the Total Environment , v. 213, p. 85-94, 1998. Disponível em <http://www.sibi.usp.br/sibi/biblioteca/revista/selecao.php>. Acesso em: 17 jan. 2004.

ZAFAR, I.M.; MUHAMMAD, S. Periodical effects of automobile pollution on the growth of some roadside trees. Ekológia (Bratislava), v.19, n1, p.104-110, 2000. 